\title{
ANÁLISE DE UM PROCESSO PARTICIPATIVO NA EXPERIÊNCIA DE IMPLANTAÇÃO DE UM PROJETO MUNICÍPIO SAUDÁVEL
}

\section{VICTOR JUN ARAI}

Dissertação apresentada ao Departamento de Prática de Saúde Pública da Faculdade de Saúde Pública da Universidade de São Paulo para obtenção do Grau de Mestre

Área de Concentração: Serviços de Saúde Pública

Orientadora: Profa. Dra. MÁRCIA FARIA WESTPHAL

São Paulo

2002 


\section{AGRADECIMENTOS}

À comunidade de Bertioga, especialmente aos membros da antiga Comissão Intersetorial, por todo apoio ao nosso trabalho.

A professora Márcia Faria Westphal pelo incentivo e apoio nos momentos mais dificeis.

Às professoras Eda Terezinha de Oliveira Tassara e Helena Ribeiro pelas importantes observações nas fases de qualificação e de pré banca.

Ao professor Marcos Sorrentino pelo incentivo ao meu mestrado.

À Gislaine pela indicação dos primeiro passos ao mestrado.

Aos amigos e colegas Rosilda, Cláudia, Ana, Francisco, Marcelo, Lúcia, Letícia, Endyra pela solidariedade e apoio em todos os momentos. Vocês me ajudaram muito!

A Lápis pela organização do banco de dados e por suas valiosas orientações na manipulação dele.

Aos estagiários Samuel, Carol e Silvia pelo trabalho de sistematização do banco de dados, transcrição de fitas e apoio logístico em Bertioga.

À Daniela pela dedicação e cuidado na transcrição de fitas.

À Denise pela revisão de todo o texto e apoio nas horas cruciais.

A Beth pela confecção dos mapas.

À Luisa e Marcela pela revisão dos textos iniciais.

À Cristina pelo apoio na revisão dos textos.

Ao pessoal da CPG Márcia, Cidinha e Renilda pelo apoio e orientação imprescindivel.

Aos motoristas da faculdade pelo apoio no transporte.

Às secretárias de nosso departamento por sua amável disponibilidade.

Aos meus pais pelo apoio incessante em todos os momentos.

Muito obrigado a todos!

Finalmente: à CAPES pelo apoio financeiro. 


\section{RESUMO}

Arai, VJ. Análise de um processo participativo na experiência de implantação de um projeto municipio saudável. São Paulo. 2002.

(Dissertação de Mestrado - Faculdade de Saúde Pública da USP)

Este trabalho se propôs a analisar a participação da sociedade civil na formulação e implementação do Projeto Bertioga Municipio Saudável de Bertioga, de acordo com os pressupostos de sustentabilidade, participação social, equidade e intersetorialidade. Utilizou-se da metodologia da pesquisa-ação para identificar, caracterizar o tecido social de Bertioga, isto é, os diversos atores sociais, movimentos sociais e grupos/organizaçōes/instituiçōes, seus interesses, necessidades e sonhos em relação ao municipio de Bertioga. O uso combinado de técnicas permitiu que esta investigação se iniciasse por um levantamento mais superficial de lideranças do municipio, e continuasse a partir de outras técnicas aprofundando o conhecimento dos principais problemas, aspectos positivos e sonhos para Bertioga. Através desta abordagem participativa, oficinas de sensibilização e oficinas do futuro foram realizadas para sensibilizar e esclarecer a população sobre o projeto e iniciar um processo de planejamento a partir de suas percepções acerca do municipio, dos problemas e da sua causalidade. Os resultados obtidos foram: um mapeamento das lideranças municipais, os diversos grupos, entidades, organizações e instituições do municipio nos quais elas militam, suas lutas e atividades. Várias iniciativas foram identificadas, constatou-se a multiplicidade de suas ações, e sua distribuição em território municipal. As percepçōes dos participantes, quase consensuais, foram de que os problemas municipais prioritários são deficiências no saneamento básico, na oferta e qualidade de serviços de saúde e segurança, variando a intensidade da preocupaçāo por áreas do municipio. Os sonhos porém, modificaram o ranking de prioridades colocando as praias e os recursos naturais como as fontes de maior orgulho porém, o desejo de ter uma administração municipal que se empenhe por 
resolver os problemas mencionados e preservar os recursos naturais e a identidade cultural, como de maior prioridade pelos grupos participantes. A metodologia combinou componentes racionais, cognitivos e subjetivos que estimularam a inserção da população nas atividades do projeto, permitindo ao final de um ano, dizer que estava iniciado o projeto e a sua organização, via formação da Comissão Intersetorial, com base em forte compromisso da população. Este primeiro ano, portanto, deu inicio à formação de uma rede de apoio ao projeto, que o sustentou no momento da mudança de governo.

Descritores: Cidade saudável. Participação da população. Subjetividade. Promoção da saúde. Rede. 


\section{SUMMARY}

Arai, VJ. Análise de um processo participativo na experiência de implantação de um projeto municipio saudável [Participatory process analysis in an experience of a health city project]. São Paulo. 2002.

(Master Thesis - Faculdade de Saúde Pública - USP)

This study was purposed on analyzing popular participation on formulating and implementing the Bertioga Health City Project, according to sustainability, social participation, equity and intersetoriality principles. Research-action was the chosen methodology to identify and characterize Bertioga's social tissue - various social actors, social movements and groups/organizations/institutions, their interests, needs and dreams related to Bertioga's municipality. The combined use of assessing techniques gave the process the characteristic of a gradually investigating process. It began from a more superficial approach with a population survey identifying the leaderships of the municipality and continue with other techniques to in depth the upraisen knowledge related to the main problems, positive components and dreams related to Bertioga. With this mixed participatory approach, survey, sensitization workshops, and "planning the future" workshops it was possible to achieve the purpose of warning population about the project and beginning planning activities where the people are, in other words from their perceptions. The results of the survey conducted was the identification of various leaders, groups, entities, organizations and institutions in the municipality, their fights and activities - it was evidenced many initiatives, the multiplicity of their actions and their distribution all over the municipal territory. The main perceived problems, almost consensual, were deficiency on sanitation, centralization of health resources and insecurity, with variations of intensity according to municipality areas. The dreams modified the priorities they gave to the problems, giving to the beaches and existence of beautiful natural resources the title of a great value assets, and the main dream - the possibility to have a honest and efficient city administration that can deal with problems and preserve the nature. 
The methodology counted on rational, cognitive and a strong subjective component, which has stimulated population participation on project activities and has started the development of the project with a "city council" and a network for supporting that project.

KEY WORDS: Healthy city. Population participation. Subjectivity. Health promotion. Network. 


\section{SUMÁRIO}

INTRODUÇÃO

CAPITULO 1 - O PROBLEMA: PARTICIPAÇÃO SOCIAL NA CONTEMPORANEIDADE, A CRISE DE IDENTIDADE REGIONAL OU LOCAL E A ESTRATÉGIA DE MUNICIPIOS EIOU CIDADES SAUDÁVEIS

Crise de Identidades e a Desterritorialização

A Participação Social para a Sustentabilidade:

Municipios/Cidades Saudáveis

CAPÍTULO 2 - FUNDAMENTAÇÃO TEÓRICA

Novo Paradigma da Saúde e os Projetos Estruturantes

Municípios/Cidades Saudáveis

Conceitos de Participação

26

Sociedade Civil / Estado: novos posicionamentos

"Velhos e Novos" Movimentos, Conflitos

e Atores/ Sujeitos Sociais

30

Redes, Açōes Coletivas e Movimentos Sociais

Gerais

Especificos 
CAPÍTULO 5 - CONSTRUINDO O MUNICÍPIO SAUDÁVEL POR MEIO DE PESQUISA AÇÃO PARTICIPANTE

Critérios para decisão sobre a temporalidade

(corte) a ser estudada

Aspectos práticos da pesquisa-ação

Pesquisa Exploratória

Oficinas de sensibilização

Oficinas do Futuro 66

Coleta registro e análise dos dados

CAPÍTULO 6 - DESENVOLVENDO O PROJETO BERTIOGA MUNICIPIO SAUDÁVEL - PRIMEIROS ACERTOS: O COMPROMISSO DO MUNICÍPIO

Primeiros Passos 79

Um diagnóstico inicial 81

Sensibilização nas regiōes 85

Planejando o Futuro 88

Reunindo as agendas para o futuro

CAPITULO 7 - ATORES SOCIAIS E SUAS PERCEPÇÕES SOBRE A REALIDADE DE BERTIOGA

A participação da sociedade civil na criação do Projeto (Iniciativa) Bertioga Município Saudável

Bertioga e seus Atores: Percepção do Presente, suas Raízes

A falta de saneamento básico

Causalidade dos Problemas de Saneamento

Percepção Negativa do Atendimento à Saúde 
Relação entre problemas de saúde e outros problemas: a visão de causalidade múltipla do processo saúde/doença

Clientelismo e Salário x Direitos de Cidadania como Causa

indireta dos Problemas de Atendimento à Saúde

Percepção da Falta de Segurança

Relação da Falta de Segurança e alguns de seus Fatores Causais 117

A limpeza pública como problema sentido

Praias

Praias: um potencial de valorização que não pode ser perdido

Sossego ou Insegurança: um misto de preocupação e valor

Recursos Naturais: outro valor? O ecossistema precisa ser preservado?

A Identidade com o Local e o Cultural

A Fragmentação do Território

Olhares Diversos dos Diferentes Atores

Pontos de vista diferentes: conflitos e negociação de acordos e propostas de ações

Sonhos: uma utopia norteadora

Uma Tentativa de Sistematização

CAPITULO 8 - RELAÇÃO DOS RESULTADOS COM O REFERENCIAL TEÓRICO: PARTICIPAÇÃO SOCIAL E CIDADE SAUDÁVEL

O Efeito das Metodologias Participativas no Protagonismo dos Atores Sociais de Bertioga

Objetivos das Oficinas do Futuro

A formação da Rede de Apoio ao Projeto

Bertioga Município Saudável 
ANEXOS 


\section{Lista de Figuras}

Figura 1 - Gráfico das 16 ocupações dos participantes mais citadas durante as atividades do PBMS

Figura 2 - Gráfico das citações de grupos, entidades, organizações e instituições de Bertioga nas quais os entrevistados na Pesquisa exploratória participam.

Figura 3 - Gráfico dos problemas de Bertioga citados pelos entrevistados na Pesquisa exploratória.

Figura 4 - Gráfico dos problemas da Área 1

Figura 5 - Gráfico dos problemas da Área II

Figura 6 - Gráfico dos problemas da Área III

Figura 7 - Gráfico dos problemas da Área IV

Figura 8 - Gráfico dos problemas da Área V

Figura 10 - Gráfico dos aspectos positivos de Bertioga citados pelos entrevistados na Pesquisa exploratória.

Figura 12 - Gráfico do número de ocorrência dos sonhos mencionados pelos entrevistados na Pesquisa exploratória. 


\section{Lista de Fotos}

Foto 1 - Praia de Itaguaré $\quad 44$

Foto 2 - Condomínio Riviera de São Lourenço 45

Foto 3 - Desenho com giz de cera - Oficina de sensibilização 62

Foto 4 - Visualização dos atores sociais $\quad 65$

Foto 5 - Muro das lamentações e árvore dos sonhos 67

Foto 6 - I Seminário Municipal no SESC Bertioga 92

Foto 7 - Falta de limpeza em Vicente de Carvalho II 118

Foto 8 - Sociograma com o Grupo do Futuro 133 


\section{Lista de Tabelas}

Tabela 1 - Atividades realizadas durante o ano de 2000 pela Faculdade de Saúde Pública da USP

Tabela 2 - Total de participantes em cada atividade e percentual de retorno em atividades posteriores do Projeto Bertioga Municipio Saudável

Tabela 3 - Lutas das entidades de Bertioga associadas às áreas

Tabela 4 - Participação da Comissão intersetorial nas atividades do Projeto

Bertioga Município Saudável no ano de 2000

Tabela 5 - Envolvimento dos membros da Comissão Intersetorial nas atividades do Projeto Bertioga Município Saudável no ano de 2000

Tabela 6- Participação da Comissão Intersetorial formada em 2001 nas atividades do Projeto Bertioga Município Saudável no ano de 2000

Tabela 8 - Sistematização dos principais problemas, lutas dos grupos e organizações, prioridades e dados de participação quantitativa por áreas do município 


\section{Lista de Abreviaturas}

BID - Banco Interamericano de Desenvolvimento

USP - Universidade de São Paulo

ONGs - Organizações não-governamentais

CEPAL - Comissão Econômica para a América Latina e o Caribe

OMS - Organização Mundial da Saúde

IBGE - Instituto Brasileiro de Geografia e Estatística

PDDS - Plano Diretor de Desenvolvimento Sustentado

CODESP - Companhia Docas do Estado de São Paulo

SESC - Serviço Social do Comercio

CESP - Companhia Energética de São Paulo

FUNAI - Fundação Nacional do Índio

WHO - World Healthy Organization

PBMS - Projeto Bertioga Município Saudável

OPAS - Organização Panamericana da Saúde

EMEIF - Escola Municipal de Educação Infantil

PSB - Partido Socialista Brasileiro

PRP - Partido Republicano Progressista

PPB - Partido Progressista Brasileiro

PV -Partido Verde

PSDB - Partido da Social Democracia Brasileira

$\mathrm{PL}$ - Partido Liberal

PT - Partido dos Trabalhadores

PPS - Partido Popular Socialista

FAPESP - Fundação de Amparo à Pesquisa do Estado de São Paulo

OS1 - $1^{\circ}$ Oficina de Sensibilização

PE - Pesquisa Exploratória

OR - Oficinas Regionais de Sensibilização

OF - Oficinas do Futuro

SM - I Seminário Municipal do Projeto Bertioga Município Saudável

$\mathrm{Cl}$-Comissão Intersetorial 
TPE - Treinamento para a Pesquisa Exploratória

COR - Coordenação das Oficinas Regionais

ROR-Relatoria das Oficinas Regionais

AOR - Avaliação das Oficinas Regionais

TOF - Treinamento para as Oficinas do Futuro

COF - Coordenação das Oficinas do Futuro

ROF - Relatoria das Oficinas do Futuro

AOF - Avaliação das Oficinas do Futuro

SUS - Sistema Único de Saúde 


\section{Anexos}

Anexo 1 - Estado de São Paulo: localização do município de Bertioga Anexo 2 - Municipio de Bertioga: área urbana e hidrografia Anexo 3 - Questionário para levantamento de lideranças, grupos, organizações, entidades e instituições Anexo 4 - Termo de consentimento livre e esclarecido Anexo 5 - Ficha de inscrição para as Oficinas regionais Anexo 6- Roteiro para a primeira Oficina de sensibilização Anexo 7 - Roteiro das oficinas regionais Anexo 8 - Segunda reunião: raizes dos problemas Anexo 9 - Terceira reunião: atores sociais Anexo 10 - Quarta reunião: agenda XXI do pedaço Anexo 11- Roteiro de entrevista individual Anexo 12 - Município de Bertioga: mapa de localização da Área I (A) Anexo 13 - Municipio de Bertioga: mapa de localização da Área II (B) Anexo 14 - Municipio de Bertioga: mapa de localização da Área III (C) Anexo 15 - Municipio de Bertioga: mapa de localização da Área IV (D) Anexo 16 - Município de Bertioga: mapa de localização da Área V (E) Anexo 17 - Quadro 1 - Atividades desenvolvidas no Projeto Bertioga

Municipio Saudável e seus participantes Anexo 18 - Folheto para divulgação da Pesquisa exploratória Anexo 19 - Convite impresso para as Oficinas regionais Anexo 19 - Convite impresso para o I Seminário Municipal do Projeto Bertioga Município Saudável Anexo 20 - Convite impresso para as Oficinas do futuro 
INTRODUÇÃO 
A questão de participação social, apesar de fluxos e refluxos, continua atualmente presente em textos e documentos, encontros e conferências internacionais, nos meios de comunicação e no cotidiano da população. Os novos enfoques de saúde (WESTPHAL 2000) e a Promoção da Saúde privilegiam como uma das estratégias de ação neste campo a participação social e a redistribuição do poder para desenvolver seus programas dentro de um conceito integral de saúde (CERQUEIRA 1997 p.24). Organismos financiadores como o BID (Banco Interamericano de Desenvolvimento) e o Banco Mundial também têm, entre suas exigências, cláusulas que condicionam a aprovação e financiamento de projetos à participação de segmentos da sociedade nos mesmos (NELSON e WRIGHT 1995). Partidos e grupos políticos levantam a bandeira da participação em suas plataformas eleitorais e em seus projetos de governo.

A participação insere-se, também, na discussão de práticas políticas locais, como a implantação do orçamento participativo, o qual se constitui, hoje, em um exemplo bem-sucedido, implementado em várias cidades brasileiras (GOHN 1997 p. 317). Proliferam-se conselhos representativos das mais diferentes temáticas e grupos sociais, comitês e subcomitês de gestão de bacias hidrográficas e outras formas de representatividade, reforçando a idéia da importância dos processos participativos na implementação e gestão de recursos e politicas.

Dentro do tema da participação social, em uma modalidade de projeto estruturante de Promoção da Saúde denominado Municípios/ Cidades Saudáveis, estamos nos propondo a estudar como se dá a mobilização dos diversos atores sociais e a sua organização, na busca de melhor qualidade de vida diante de um quadro de miserabilidade que afeta todo o País, o qual está relacionado diretamente com diversos conflitos de interesse. Partimos do pressuposto de que a interaçāo desses atores, o poder público, a universidade $\mathrm{e}$ instituições da sociedade civil pode gerar efeitos no plano 
social e político-institucional não previsiveis, em função da mediação simbólica que as representações sociais da população estabelecem com base nas suas condições objetivas de vida.

Considerando esses aspectos, o objetivo do presente estudo é analisar a participação da sociedade civil na formulação e implementação do Projeto Bertioga Município Saudável. A área geográfica escolhida é o município de Bertioga, próximo aos municípios de Santos, Guarujá e São Sebastião, no Estado de São Paulo. Desde fevereiro de 2000, Bertioga tornou-se uma das cidades brasileiras integrantes do movimento por Municípios/Cidades Saudáveis.

A partir da assinatura de um protocolo de intenções, no início do ano 2000, entre a Prefeitura Municipal de Bertioga, a Faculdade de Saúde Pública e outras unidades da Universidade de São Paulo - USP, vêm sendo desenvolvidas ações conjuntas procurando:

- Direcionar o desenvolvimento econômico e social de Bertioga, para a melhoria da qualidade de vida da população, de forma sustentável.

- Promover o desenvolvimento de ações intersetoriais e interdisciplinares, com a estreita colaboração entre o governo municipal e organizações da sociedade civil, de modo que as aspirações locais sejam atendidas de forma planejada e a distribuição dos recursos públicos ocorra eqüitativamente, com eficácia e eficiência.

- Fortalecer a população de Bertioga, pelo Projeto, por intermédio de estímulos à sua auto-organização e efetiva participação no mesmo. 
A estratégia de implantação do Projeto Bertioga Municipio Saudável prevê, entre outras atividades, 0 intercâmbio de conhecimentos, experiências e informações, bem como a prestação de assessoria técnica e científica da Faculdade de Saúde Pública e outras unidades da USP à Prefeitura Municipal de Bertioga.

A partir da assinatura do protocolo de intenções, já foram desenvolvidas algumas etapas que serão descritas no capítulo 6.

Esta dissertação de mestrado aborda os seguintes aspectos, abordados nos capítulos e tópicos a saber: o Capitulo (1) delimita a problemática da participação no mundo contemporâneo e a situa no Projeto Municípios/Cidades Saudáveis; no Capítulo (2), estão definidos os conceitos fundamentais para a construção do referencial de análise; o Capítulo (3) define os objetivos que nortearão o eixo central de toda a investigação; no Capítulo (4), descreve-se o cenário de estudo em seus aspectos vinculados aos objetivos do projeto; o Capítulo (5) expõe e fundamenta a metodologia utilizada; no Capítulo seguinte, (6), relata-se o histórico do desenvolvimento do projeto; no Capítulo (7), sistematiza-se os resultados quantitativos quanto à participação e as percepções dos participantes das oficinas com relação à realidade de Bertioga; o Capítulo (8), discute os resultados e nas Considerações Finais apresenta-se resultados da pesquisa; e, por fim, um tópico especifico relaciona a referência bibliográfica utilizada. 


\section{CAPÍTULO 1}

\section{O PROBLEMA:}

PARTICIPAÇÃO SOCIAL NA CONTEMPORANEIDADE,

A CRISE DE IDENTIDADE REGIONAL OU LOCAL E A ESTRATÉGIA DE MUNICÍPIOS/CIDADES SAUDÁVEIS 
Para uma melhor compreensão da problemática da participação na contemporaneidade, será feita uma abordagem com enfoque em dois aspectos: a participação em si e a "crise" de identidades.

SOUZA SANTOS (1995 p. 21), ao tecer considerações sobre algumas das perplexidades sociológicas neste final de século, julgou que a democracia conseguiu um consenso resultante do desaparecimento da clivagem entre socialismo e capitalismo, mas alguns de seus conceitos satélites, como a participação e a representação, encontram-se em aparente "crise".

Existe, conforme SOUZA SANTOS (1995, p. 29), uma aparente apatia política, conformismo e abstencionismo por parte da sociedade em relação a estilos de vida e de imaginários sociais mais coletivos.

Quanto à representação política, BENEVIDES (1991, p. 12) considerou que, apesar desta ser legítima e indispensável nas democracias modernas, não consegue exprimir, com fidelidade, a vontade popular, na diversidade de suas manifestações. Cidadãos comuns querem opinar e participar dos atos de quem os governa e têm criado novos espaços de participação (SCHERER-WARREN 1996, p. 26).

A abordagem desta "crise" e esta aparente contradição entre o desejo e a ação está baseada na descrição que SOUZA SANTOS (1995, p. 77-78) fez do desenvolvimento do projeto sociocultural da modernidade. Para ele, este projeto estaria assentado em dois pilares fundamentais: o pilar da regulação e o pilar da emancipação. $O$ pilar da regulação seria composto pelos princípios de atuação e a definição do Estado (componente político), do mercado (componente econômico) e da comunidade (componente da participação). 
Por sua vez, o pilar da emancipação seria constituído por três lógicas de racionalidade: a racionalidade estético-expressiva, da arte e da literatura; a racionalidade moral-prática, da ética e do direito; e a racionalidade cognitivo-instrumental, da ciência e da técnica. Ao discorrer acerca das tensōes entre o pilar de regulação e o pilar de emancipação em alguns periodos históricos, é possível perceber o ponto de vista do autor, de como ocorre $o$ equilibrio ou 0 desequilibrio entre os diversos principios $e$ as racionalidades expostas. $O$ aspecto da participação estaria ligado, basicamente, ao principio da comunidade de origem rousseauniana - neste momento, portanto, ainda no pilar regulatório e ainda longe do pilar de emancipação.

O tempo histórico, percorrido por SOUZA SANTOS (1995, p.79-92) para esta análise, está ligado ao desenvolvimento do capitalismo nos países centrais, abrangendo todo o século XIX até os dias de hoje. Ele distingue três grandes periodos. $O$ primeiro periodo, cobrindo todo o século $X I X$, denominado de capitalismo liberal. O segundo, abrangendo o periodo do final do século XIX até as primeiras décadas após a $2^{\circ}$ Guerra Mundial, denominado de capitalismo organizado. $E$ o terceiro período, que inicia em fins da década de 1970 e se mantém até a época atual, denominado de capitalismo desorganizado.

Neste ponto, cabe esclarecer que 0 autor denominou de países centrais aqueles nos quais o capitalismo teve pleno desenvolvimento. $\mathrm{Na}$ América Latina, incluindo o Brasil, esse desenvolvimento não ocorreu de modo integral, de maneira que seus efeitos foram parciais ou diferenciados.

No primeiro período, de acordo com a divisão temporal exposta acima, ocorreu um desenvolvimento sem precedentes do princípio do mercado (componente econômico), representado pela industrialização, acompanhado por uma atrofia do princípio da comunidade (participação) e por um desenvolvimento ambiguo do Estado, sob pressão dos dois 
movimentos anteriores. A comunidade reduziu-se de uma concepção de um conjunto de cidadãos dotados de uma soberania popular para uma concepção de sociedade civil, concebida como agregação competitiva de interesses particulares e no indivíduo, como componente básico da sociedade civil. Surge, nesse período, um dualismo Estado-sociedade civil, que será tratado adiante.

No segundo período, SOUZA SANTOS analisa a emergência das práticas classistas devido à expansão do operariado e do sufrágio universal. É nesse período que surge o Estado-Providência com forte articulação com - mercado e a comunidade. Autores como OFFE denominam aquele de Estado de Bem-Estar Liberal (1994, p. 171). No campo da racionalidade moral-prática, ocorre uma maior penetração do Estado na sociedade por meio de soluções legislativas, institucionais e burocráticas, mas, ao mesmo tempo, um afastamento de seus cidadãos. Destes se exige cada vez mais uma obediência passiva ao invés de uma mobilização ativa.

Ao analisar esse mesmo periodo, referindo-se à Europa Ocidental, OFFE (1994, p.170-3) pressupôs que, no final dos anos 1940 e princípios dos anos 1950, o estabelecimento de uma ordem social, econômica e politica, baseada num consenso extremamente amplo sobre 0 Estado de Bem-Estar Social liberal democrático, objetivava conter os conflitos, de modo que a política teria na vida da grande maioria dos cidadãos somente um significado secundário. Os elementos centrais destes acordos constitucionais baseavam-se na institucionalização das decisões acerca dos investimentos com operação e mercados livres, na organização dos trabalhadores como máquina de distribuição e seguridade social e numa forma de democracia política de tipo representativa, baseada na mediação de partidos políticos. A participação política era desvalorizada.

No Brasil, o Estado do Bem-Estar Social nunca chegou a ser implantado, pois, no período pós-1964, as prioridades governamentais 
focaram interesses econômicos em detrimento de interesses sociais (JACOBI, 1989, p. 9), agravando as condições gerais da população.

Finalmente, no terceiro periodo, o princípio do mercado passa a ter uma expansão em todo espaço mundial procurando "colonizar tanto o principio do Estado, como o princípio da comunidade" (SOUZA SANTOS 1995, p.87). Dessa forma, ocorre um enfraquecimento do Estado nacional com perda de sua autonomia e de sua capacidade de regulação social. Nesse periodo, o principio da comunidade enfraquece no sentido das práticas de classe do período anterior. É nesse contexto que surgem os novos movimentos sociais. Este tema será abordado com mais profundidade em outro item.

Para OFFE (1994, p. 166), em meados da década de 1970, nos paises da Europa Ocidental, o projeto neoconservador teve como idéia central a redefinição restritiva do que podia e do que devia ser considerado "político", com uma conseqüente implosão da autonomia e autoridade das esferas institucionais não-políticas - uma reprivatização de conflitos e tensões, de maneira a evitar ações dos cidadãos que fossem incompativeis com a manutenção da ordem institucional política. Dessa forma, houve um afastamento do Estado de algumas questões peculiares da sociedade civil (como a propriedade, o mercado, a ética de trabalho, a familia, a verdade científica). Por outro lado, houve o surgimento dos novos movimentos sociais que se "politizaram" para se emanciparem do Estado.

Quanto à racionalidade moral-prática do terceiro período, cabe destacar três dilemas apontados por SOUZA SANTOS (1995, p. 91): em primeiro lugar, valores tais como autonomia e subjetividade, cada vez mais distantes das práticas políticas e do cotidiano; em segundo lugar, uma sobrejuridificação da vida; em terceiro lugar, um confinamento a uma ética individualista, que determina uma falta de preocupação com questões mais coletivas. 
Retomando esse mesmo processo histórico no Brasil, considerado como país semiperiférico por SOUZA SANTOS (1995, p. 265), há alguns aspectos a serem destacados.

WESTPHAL (1999, p. 291) mencionou que, no Brasil, com relação às características dos movimentos participativos, existiu um passado colonial escravocrata e/ou de serviço indigena baseado na monocultura e/ou exploração de recursos naturais.

A formação do Estado nacional brasileiro caracterizou-se por lutas, nas quais as elites politicas associaram-se sempre aos interesses econômicos do capital internacional ou a uma política de troca de favores e proteções administradas por políticos locais. Os regimes politicos, até os anos de 1930, por exemplo, são fruto de uma aliança entre as oligarquias rurais apoiadas por setores de um clero tradicional católico (WESTPHAL 1999, p. 292).

Durante o período de 1930 a 1960 , devido ao processo urbano industrial que se inicia, houve uma organização do movimento operário, o qual se colocou como uma porta de entrada para a participação, algumas vezes posicionando-se contra o Estado, algumas vezes cooptado por ele (WESTPHAL 1999, p 292).

Entre o período do final da Segunda Guerra Mundial até os anos de 1960 , surgem muitos partidos políticos, movimento sindicais, movimentos de base nos bairros e ligados à Igreja (ibidem). Com o advento da ditadura, muitos desses partidos políticos e movimentos são extintos ou reprimidos.

Diferentemente dos paises chamados centrais, onde houve uma combinação de democracia participativa com valores e reivindicações pósmaterialistas, no Brasil e na América Latina, de um modo geral, houve uma 
combinação de luta pela democracia, com reivindicações para o atendimento de necessidades básicas.

Confirmando esta afirmação, JACOBI (1989) relacionou a eclosão dos movimentos sociais urbanos como uma reação a um modelo econômico excludente, conduzido por um regime autoritário.

No periodo de redemocratização do Brasil, durante a década de 1970, quando o governo precisava se legitimar, este assumiu uma faceta moderna de Estado, tanto como indutor das demandas sociais quanto de receptor, negociador e transformador destas, em ações de atendimento a reivindicações. Nesse periodo, o canal com o Estado esteve mais aberto e propício à ascensão dos movimentos sociais urbanos, de caráter reivindicatório de condições de reprodução da força de trabalho (JACOBI 1989).

Com o processo de redemocratização em andamento e a crise de autoritarismo do pais, durante os anos 1980 , ocorreu uma maior visibilidade dos movimentos sociais que, ao estabelecerem novas relações com o Estado, criaram uma tensão entre seu caráter autônomo e de resistência, abrindo espaço para a institucionalização da participação social (JACOBI 1989; GOHN 1997).

No final dos anos 1980 e início dos anos 1990, com o advento do neoliberalismo e a tendência do Estado de se tornar mínimo, acoplado a uma estratégia para conter os movimentos, houve uma abertura do aparelho estatal para a participação de grupos organizados da população, via representação em conselhos de saúde e outros espaços de participação no aparelho do Estado (WESTPHAL 1992; BOGUS 1997, p. 20). A partir desse momento, iniciou-se a institucionalização da participação social, estabelecendo novas relaçōes dos movimentos sociais com o Estado. Aos poucos, concomitantemente, foram surgindo novos atores institucionais 
como, por exemplo, as organizações não-governamentais (ONGs), com atuação nas mais diversas áreas (GOHN 1997, p. 303). Às vezes criaram e institucionalizaram novos movimentos sociais: étnicos, de gênero, ecológico; outras vezes, assumiram a iniciativa de resolução de problemas locais em lugar do Estado.

A institucionalização, relacionada à participação em conselhos outros novos atores -, resultou no estabelecimento de parcerias com o poder público e na participação em instâncias de consulta ou tomada de decisão. Para GOHN (1997, p. 310-3), as regras dessas novas estruturas colegiadas têm sido estabelecidas por iniciativa dos governantes muito mais do que por uma pressão popular, já que o Estado e seus representantes não necessitam mais dos movimentos para se legitimarem junto à sociedade em geral, contando com apoio dos partidos majoritários no Congresso Nacional.

Alguns movimentos conseguiram adaptar-se a essa nova conjuntura, alguns entraram em crise interna e de confiabilidade e legitimidade junto à própria população. Alguns perderam sua força mobilizadora, especialmente os movimentos sociais urbanos (GOHN, 1997, p. 304). Mas ocorre o surgimento de novos estilos de participação.

A crise de participação que foi mencionada talvez esteja sinalizando um novo período de mudanças. A palavra crise vêm do grego Krínein, momento de discernimento, momento de decisão. Isto pode ser um sinal de que estejam ocorrendo mudanças nos estilos de participação, nas formas de relacionamento entre poder público e sociedade civil e nas estratégias de estimular essa participação.

SCHERER-WARREN (1996, p. 21) afirmou que, nos anos 1990, surgem novas formas de organização da sociedade civil, pelas quais se contrapôs o imobilismo das massas a espaços possíveis de mobilização. 
Surgem práticas politicas articulatórias de indivíduos, de organizaçōes e de ações localizadas, constituindo-se as redes de movimentos.

E neste cenário e a partir destes pressupostos teóricos que será conduzida esta dissertaçăo.

\section{Crise de identidades e a desterritorialização}

Num mundo globalizado, no qual as relações sociais são cada vez mais desterritoriais, a identidade regional e local pode correr riscos. Por outro lado, apesar de contraditório, percebe-se uma tendência contrária de um desabrochar de identidades locais, reforçando a idéia de localismo (SOUZA SANTOS 1995, p. 22).

Alguns fenômenos mundiais reforçam a idéia dessa desterritorialidade no plano real. Nos últimos anos, no campo demográfico, por exemplo, tem ocorrido um enorme crescimento da urbanização mundial. No contexto brasileiro, a população urbana que, em 1950, mal atingia a cifra de 18 milhōes - $36 \%$ da população total -, em 2000 , já equivalia a $81,24 \%$ da população total (IBGE, 2000). Se há 50 anos nossa sociedade era considerada rural, hoje ocorre uma inversão nesse aspecto demográfico.

Certamente, mudanças de território de grupos sociais podem gerar aculturação. É o caso dos agricultores nordestinos, os quais migram para os grandes centros urbanos no Sudeste do país, mas que nesses novos territórios não podem se reproduzir culturalmente. Outro fenômeno vinculado ao inchaço das grandes metrópoles urbanas é a construção de luxuosos empreendimentos imobiliários, que servem como primeira ou segunda residência e que acabam tornando-se "guetos" isolados de uma realidade social mais ampla. Ambas as situações descritas podem dificultar o desenvolvimento de uma identidade regional e de um sentido do que BERG 
(1990) denomina de pertencimento, isto é, a criação de vínculos afetivos com a diversidade cultural e biológica, nas paisagens naturais e construídas.

Ao tratar da questão de alguns canais de participação, DEMO (1988, p.55-6) considerou a cultura como um processo de identificação comunitária. O autor definiu cultura como um conjunto de "símbolos e valores, que caracterizam o modo de ser de uma sociedade, de uma era, ou de uma determinada história". $O$ autor afirmou que, para um grupo social sentir -se comunidade, é condição básica possuir lastro cultural próprio, uma identidade.

Em muitos municípios brasileiros, essa identificação comunitária e cultural não ocorre, dificultando ainda mais o sentido de pertencimento, o que pode estar relacionado a migraçōes e a emancipações políticas recentes. Essa aculturação ocorre até mesmo em bairros de grandes metrópoles, que sofrem intensa migração. Em municipios com potencial para o turismo, um fator que concorre à falta de identificação com o local é o incentivo à freqüência turística sem que haja um trabalho de valorização da cultura local.

As "crises" que foram delineadas ocorrem em diversos municípios brasileiros e se constituem em questões que merecem investigação, pois devem influir na implantação e no êxito do projeto de Municípios/Cidades Saudáveis.

Além desses aspectos, no item seguinte serão discutidas outras questōes que justificam a relevância desta dissertação. 


\section{A Participação Social para a Sustentabilidade: Municipios/Cidades Saudáveis}

No periodo de 2 a 6 de agosto de 1999, realizou-se, em Washington, uma reunião para discutir avaliação de projetos de Municipio/Cidades Saudáveis. Como conclusão da reunião, estabeleceu-se que os esforços para construção de metodologias e instrumentos para avaliação de municípios saudáveis nas Américas deveriam priorizar quatro campos ou temas prioritários: sustentabilidade, políticas públicas, participação social e intersetorialidade (PAHO 1999). Segundo esta orientação, enfocamos neste estudo dois aspectos interrelacionados: a participaçāo social e a sustentabilidade.

Um dos problemas que podem ter os projetos Municipios/Cidades Saudáveis é a sustentabilidade dos mesmos. Uma das estratégias para mantê-los ao longo do tempo é a participação social.

O conceito de sustentabilidade, originário das ciências agrárias, baseia-se na capacidade de um sistema agrário manter sua produtividade, diante das intempéries, alterações da qualidade do solo e do meio ambiente, e outros. Esse termo, ao ser transportado a projetos de preservação ou recuperação de ecossistemas naturais, tem a ver com a sua capacidade de resistir a tensões e a sua capacidade de recuperação, diante de diversas alteraçōes (CONWAY 1987, apud HERRERO 1997, p. 86).

Ainda sobre o conceito de sustentabilidade, diversos autores, entre os quais Chambers (1988), citado por REDCLIFT (1993), referem-se à importância dos atores sociais que se relacionam com o manejo do meio ambiente, no tocante à sustentabilidade dos recursos. Da mesma forma, Conway (1988), também citado por REDCLIFT (1993), incorpora uma preocupação no contexto da tomada de decisão entre familias pobres rurais. 
Atualmente, o termo vem sendo utilizado para outros setores como o econômico, o político e o social. Ao incorporar a dimensão social, devido a uma intervenção humana na natureza, passou-se de uma sustentabilidade ecológica para uma sustentabilidade ambiental. Um enfoque mais atual de sustentabilidade agrega outros critérios de trabalho - que segundo a Comissão Econômica para a América Latina e o Caribe (CEPAL), torná-lo-ia mais complexo - tais como a intervenção da população, das politicas e das instituições (HERRERO 1997, p. 84-5).

No aspecto político, adotamos a idéia de sustentabilidade como a continuidade, a capacidade de adaptação e de recuperação de uma política pública gestada em conjunto com a sociedade civil, diante das mudanças administrativas e conjunturais. A preocupação está baseada na experiência de que muitos projetos não conseguem se manter devido à descontinuidade de governo. A maioria das "experiências" é conduzida sob a coordenação de certas correntes político-partidárias. Quando estas correntes saem do poder - por terem perdido as eleições -, são, em geral, descartadas ou ignoradas pelo novo dirigente, seja por uma falta de sensibilidade, seja por não constituirem parte de seu plano de governo devido à correlação de forças que apóiam seu projeto político (GOHN 1997, p. 317-8).

Para garantir uma certa irreversibilidade dessas novas práticas políticas, a participação social teria um papel essencial. Alguns autores destacam a importância da participação social relacionada a esse conceito de sustentabilidade (HERRERO 1997; GOHN 1997).

No caso de projetos de Municipios/Cidades Saudáveis, FERRAZ (1993, p. 45) recomenda, para as cidades brasileiras, uma autonomia municipal em relação a uma maior independência do nivel ministerial ou estadual. 
MALIK (1997, p. 24-5), sugere que a formação de lideranças efetivas pode garantir a permanência do projeto no município, mesmo após mudanças no governo municipal.

Em um texto recente, DEMO (2000) atribuiu ênfase no controle democrático como possibilidade da sustentabilidade do desenvolvimento, sobretudo da competência política da população para imprimir qualidade aos projetos.

Nesse aspecto, os Projetos de Municípios/Cidades Saudáveis deveriam estar a serviço da população e sob seu controle democrático, sendo que o Estado teria um papel de gestão compartilhada do projeto e não de protagonista. $\mathrm{Na}$ prática, isso não ocorre devido a uma falta de competência politica da população, historicamente produzida e cultivada (DEMO 2000; WESTPHAL 2000). DEMO (2000 p.7) definiu competência politica como "a competência propriamente humana de constituir-se sujeito consciente e capaz de orientar seu destino, dentro das circunstâncias dadas". No caso do Projeto Bertioga Municipio Saudável, esta competência deve ser vista de um ponto de vista coletivo.

Identificar os fatores envolvidos na definição do estágio de competência política de um segmento da população de Bertioga, que se encontra dispersa nos bairros e é desconhecedora até da sua condição de pobreza, é um dos propósitos deste estudo. Conforme DEMO (1988), a pobreza política define a condição do pobre que sequer sabe que é pobre pelas próprias condições de sua vida. Será possivel, nessa situação de carência, haver possibilidade de mobilização por participação social autônoma e independente?

Outros segmentos a serem considerados, com importante papel na implantação de municipios/cidades saudáveis, são o terceiro setor (ONGs) e o setor privado. Dentro de uma concepção mais ampla de sustentabilidade e 
de participação social, cabe ao setor privado e as ONGs um papel fundamental, pois a responsabilidade social por saúde cabe a todos os componentes da sociedade civil (DECLARAÇÃO DE JACARTA apud OMS 1997, MÉXICO 2000). O setor privado é responsável direto pelo desenvolvimento das atividades econômicas nos municipios. As ONGs constituem-se em entidades da sociedade civil, "sem fins lucrativos", que atuam em diversas atividades incluindo as assistenciais, educacionais, defesa do meio ambiente, questões étnicas, de gênero, e outras (GOHN 1997). Na situação de participação, cada segmento ingressa com seus interesses, por vezes contraditórios; e o que se deve esperar não é o consenso, mas a negociação, em função do interesse coletivo na construção e desenvolvimento dos projetos de Municípios/Cidades Saudáveis.

Neste ponto, cabe ressaltar que o despreparo da população e de suas lideranças no desempenho de certas habilidades, tais como as de negociação, de planificação e de construção de políticas, pode ser minimizado por meio do apoio de "intelectuais orgânicos" (DEMO 2000, p.10) ou de mediadores (SCHERER-WARREN 1996, p 60). Entende-se por intelectual orgânico aquele que possui um vínculo estreito com as classes que representa. $O$ intelectual orgânico desenvolve uma "adesão orgânica" à classe que representa, expressa pelo "sentimento-paixão que aos poucos transforma-se em compreensão e portanto saber" (GRAMSCl apud PORTELLI 1972, p. 83-6). Estes podem provir do Estado, de ONGs, da própria comunidade, da Universidade ou de agentes ligados às comunidades (DEMO 2000, p . 10). Este papel pode ser exercido com base em sua intermediação como aglutinadores de moradores e segmentos dispersos, por meio do fortalecimento de objetivos e valores comuns (JACOBI \& NUNES 1985; SCHERER-WARREN 1996, p 60), como agentes capacitadores no desenvolvimento de novas habilidades e como mediadores dos conflitos de interesses entre os diversos grupos. 
DALLARI (2001, p. 98) considerou fundamental que se preparem as pessoas para uma participação política por intermédio de atividades que gerem uma reflexão, a qual demonstre a importância da convivência entre os seres humanos com justiça.

Pederson, O'Neill e Rootman, citados por CERQUEIRA (1997, p.16) assinalam que as investigações no campo da promoção da saúde, no Canadá, ainda têm sido majoritariamente descritivas, havendo necessidade de determinação de estratégias e métodos, eficientes e eficazes, para provocar mudanças significativas quanto à expectativa dos resultados.

A formulação e a implementação de projetos demonstrativos de Municipios/Cidades Saudáveis como o que vem se desenvolvendo em Bertioga, prevê o teste e a avaliação de estratégias e métodos participativos e outras metodologias. Essas atividades de investigação devem possibilitar a obtenção de um instrumental adequado para os atores sociais, de modo a intensificar os esforços em direção à sustentabilidade do projeto e à participação social. 


\section{CAPÍTULO 2}

FUNDAMENTAÇÃO TEÓRICA 
$\mathrm{Na}$ fundamentação teórica, procuramos delimitar um campo de análise que permitisse compreender a questão da participação relacionada à problemática exposta e comentada no Capítulo 1. Algumas categorias e concepções são fundamentais para esta compreensão, tais como: os novos paradigmas para a saúde - incluindo a idéia de municipio saudável -, as diversas idéias de participação, e outros conceitos como atores, movimentos e conflitos sociais, sociedade civil e sua relação com o Estado, açōes coletivas na era da globalização.

\section{Novo Paradigma da Saúde e os Projetos Estruturantes Municipios/Cidades Saudáveis}

Existem estudos sobre o modelo de atenção à saúde em vigor, centrado na assistência individual e curativa, 0 qual, concebido setorialmente, não resolve os problemas de saúde. Os gastos neste setor exigem cada vez mais recursos e há cada vez menos retorno desses investimentos. Alguns autores e documentos destacam que a saúde não pode ser "cuidada" de forma setorial, pois os problemas de saúde são resultantes de um conjunto de fatores sociais, econômicos, políticos, culturais, ambientais, comportamentais e biológicos (MENDES 1996; CARTA DE OTTAWA 1986, apud MINISTÉRIO DA SAÚDE 1996; WESTPHAL 1997; DECLARAÇÃO DE JACARTA apud OMS 1997).

No inicio da década de 1970 , muitos países começaram a perceber os efeitos dos custos do setor saúde, acompanhados de uma sensação de ineficiência das práticas voltadas somente para a cura das doenças. Dessa experiência, surgiram os conceitos de Atenção Primária à Saúde e uma ênfase na participação das comunidades no planejamento dos serviços de saúde (ASHTON 1992, p.3-4). 
A crise no setor saúde, as mudanças que vêm ocorrendo no espaço urbano internacional, tais como o crescimento da urbanização, mudanças na concepção de Estado, a globalização, conflitos culturais, religiosos e ambientais, fizeram que diversas iniciativas se constituissem, fomentando a discussão do acesso à vida, com qualidade, nas cidades (WESTPHAL 1997).

FERREIRA Leila da Costa (1998, p. 23), ao analisar as políticas públicas no Brasil com relação à questão ambiental, sugeriu que, devido às mudanças no perfil da população, o papel do Estado vem se redefinindo, tornando-se menos cristalizador, pois a população dos núcleos urbanos começa a demonstrar que, localmente, é capaz de decidir sobre seus próprios problemas. É no espaço do município que residem as maiores possibilidades da participação cidadã. É no encontro e desencontro dos movimentos da sociedade civil, de um lado, e do poder público, de outro, que se materializam programas, projetos e parcerias.

Algumas dessas iniciativas vinculadas às mudanças citadas anteriormente originaram um movimento por uma nova saúde pública, que priorizava as condições dos mais pobres, com reorientação dos serviços médicos e dos sistemas de saúde e ênfase na importância do envolvimento e parcerias entre os setores público, privado e voluntário (ASHTON 1992, p. 4). Com base em uma concepção ampliada de saúde é que surgiu o Projeto Municípios/Cidades Saudáveis.

O movimento de Municípios/Cidades Saudáveis originou-se no começo da década de 1970, em Toronto, no Canadá, como uma das propostas estratégicas de trabalho em saúde. Desde então, vem mobilizando autoridades locais, técnicos e população, por intermédio de novas formas de ação, a criar melhores condiçōes de vida para a população (STROZI \& GIACOMINI apud WESTPHAL 1997). 
Em nivel internacional, o termo Municipios/Cidades Saudáveis vem sendo empregado para expressar uma filosofia de ação, baseada em uma concepção ampla de saúde que incorpora, além dos aspectos biológicos que interferem no processo saúde doença, os determinantes sociais, econômicos e ambientais, ou melhor, que ampliam o conceito de saúde, para além da consideraçäo simples de saúde como "ausência de doença" (WESTPHAL 1997, p.12).

A Organização Mundial da Saúde (OMS, 1995, apud WESTPHAL, 1997) definiu, em 1995, dez requisitos para uma cidade saudável:

- Um ambiente físico limpo e seguro incluindo a qualidade da habitação;

- Um ecossistema estável e sustentável;

- Uma comunidade forte, que funcione como apoio social e onde não haja exploração;

- Alto grau de participação social e controle público das decisões que afetam suas vidas;

- Necessidades básicas satisfeitas para todos os cidadãos;

- Acesso a experiências, recursos, contatos, interações e comunicações;

- Economia local diversificada e inovadora;

- Orgulho e respeito pela herança biológica e cultural;

- Serviços de saúde acessíveis a todos;

- Alto nivel de saúde.

Para ALMEIDA (1997 p. 79) um município nunca chega a ser saudável, pois esse processo deve ser permanente, isto é, a busca deve ser por municípios mais saudáveis.

O enfoque de município/cidade saudável leva em conta questões como intersetorialidade, participação social, preservação do meio ambiente físico e social, e outros, que visam a intervir no processo saúde-doença, objetivando a produção social da saúde e a sua promoção, e não 
simplesmente a organização de um sistema de atenção médico-curativo. Nesta dissertação, será dado um enfoque maior à questão da participação social em municípios/cidades saudáveis.

A Promoção da Saúde define-se como:

um processo, através do qual a população se capacita e busca os meios para conseguir controlar os fatores que favorecem seu bem estar e da comunidade ou que podem a estar pondo em risco, tornando-a vulnerável ao adoecimento e prejudicando sua qualidade de vida. (CARTA DE OTTAWA, 1986, apud MINISTÉRIO DA SAÚDE, 1996).

CERQUEIRA (1997 p.7), ao analisar os desafios e perspectivas para a Promoção da Saúde, comenta que, na década de 1980, a promoção da saúde tornou-se uma importante estratégia no campo da saúde pública na Europa e América do Norte, especialmente no Canadá, que enfatiza a saúde no sentido positivo.

Para essa autora, nesse periodo, houve maior descentralização dos recursos e uma maior participação social nas atividades de promoção da saúde e saúde comunitária, porém, não houve avanços no sentido de reforçar a autonomia dos atores sociais, favorecendo sua participação real no processo de tomada de decisões sobre prioridades e planos de ação.

Em diversos documentos de conferências internacionais, destacamse aspectos relacionados à participação social. A Declaração da Conferência Internacional de Promoção da Saúde, realizada em 1992, em Bogotá (DECLARAÇĀO DE BOGOTÁ 1992, apud MINISTÉRIO DA SAÚDE 1996), trouxe esta discussão para a América Latina e inclui, entre alguns de seus compromissos:

- Convocar todas as forças sociais para aplicar a estratégia de promoção da saúde. 
- Afinar mecanismos de negociação e acordos entre os setores sociais e institucionais, para levar a cabo atividades de promoção da saúde.

- Fortalecer as capacidades da população para participar nas decisões que afetam sua vida e para optar por estilos de vida saudáveis.

- Lutar contra as iniqüidades e estimular a participação da mulher.

- Estimular o diálogo de diferentes saberes, no processo de desenvolvimento da saúde.

No entanto, como ressalta CERQUEIRA (1997, p.17), citando Labonte (1994), o enfoque da promoção da saúde, no Canadá, continua centrado, hegemonicamente, numa prática individualista e num foco da prevenção da enfermidade. Labonte apud CERQUEIRA (1997, p. 18) sugere que a nova promoção da saúde "deve incorporar um enfoque mais participativo, no sentido de empoderar a população, através da conscientização sobre os fatores econômicos, sociais e políticos que determinam suas condições de saúde".

Para CERQUEIRA (1997), a promoção da saúde baseia-se em um conceito integral de saúde, que tem uma ampla determinação social, econômica e cultural, privilegiando a ampliação de poder da comunidade e a participação social como uma estratégia prioritária.

Com base nessa perspectiva ampliada do conceito de saúde, pode-se perceber a interface desta concepção com a temática da qualidade de vida. BARBOSA (1992, p. 206-7) relacionou a qualidade de vida não só a aspectos ligados à satisfação das necessidades básicas dos seres humanos - alimentação, educação, saúde, lazer, trabalho, etc. - , mas à "busca da cidadania como um processo em construção através da melhoria da qualidade de vida, fator que por si só impulsionará a participação coletiva". 
CORDEIRO (1984) analisa a qualidade de vida e as condições de saúde para o caso do Rio de Janeiro. As necessidades de saúde são remetidas ao conceito de qualidade de vida, e, desta forma, relacionadas aos determinantes sociais do processo saúde-doença. Destacou que, para o autor, não é possível separar 0 atendimento das necessidades das populações da luta dos movimentos sociais urbanos e da dimensão de cidadania.

No próximo item, discutimos alguns conceitos de participação e algumas implicações decorrentes para uma melhor compreensão de uma prática de mobilização social participativa.

\section{Conceitos de Participação}

O termo participação tem várias conceituações na medida em que for considerado um meio ou fim (AMMANN, 1978). A definição das mesmas tem sido orientada por diferentes correntes do pensamento sociológico, baseadas em diferentes ideologias ou significados. Em decorrência de participação, ou melhor de processos participativos, pode ocorrer mudança nas relaçōes de poder (DEMO, 1988, p. 19; NELSON \& WRIGHT, 1995, p. 1) e, em função disto, muitas vezes, a abertura do aparelho do Estado ou de instituições para os grupos organizados da população é temida.

Nessa mesma perspectiva, DEMO (1988, p. 18), fundamentado na Sociologia do Conflito, reforçou a idéia de que o poder de participar, inclusive a autonomia decisória, não é uma dádiva, mas sempre fruto de uma conquista e, portanto, um processo dinâmico e permanente na vida dos grupos sociais. 
DALLARI (2001) defendeu que a participação constitui-se em um direito e, ao mesmo tempo, em um dever, pois se, de um lado, é necessário que todos possam estabelecer regras de convivência para que se possa ter segurança, possa desenvolver-se e viver em paz, por outro lado, a participação é um dever, pois os seres humanos dependem uns dos outros.

AMMANN (1978) concluiu que para uma participação se considerar social, deve ser um "processo mediante o qual as diversas camadas sociais tomam parte na produção, na gestão e no usufruto dos bens de uma sociedade historicamente determinada". Para poder atingi-la, é necessário o desenvolvimento de processos de mobilização via associações e organizações sociais.

Neste sentido e de uma maneira geral, VALLA (1993, p. 13) conceituou participação social como o conjunto de "múltiplas ações para poderem influenciar a formulação, execução, fiscalização e avaliação das políticas públicas na área social".

RUIZ, referindo-se a FOREST et alli (1998, p. 13), afirmou

que distinguem duas formas de participação direta da população na gestão pública: a consulta, que associa os cidadãos à elaboração de políticas ou programas desde a concepção até a avaliação, e a participação em sentido strictu sensu, que permite aos cidadãos contribuir na gestão das organizações públicas.

WESTPHAL (1997, p. 15) ressaltou a importancia do protagonismo da sociedade civil em projetos do tipo Municipios/Cidades Saudáveis por meio da participação da população e de seus grupos organizados, que são os que vivem e sentem os problemas no seu dia-a-dia de trabalho e de convivência nas comunidades. Muitas vezes, as soluções racionalmente pensadas não são adequadas à realidade da população. 
Já RUIZ (1998, p. 24) adotou o termo protagonismo como idéia que implica "na negociação de poder e na tomada de decisões compartilhadas entre autoridades e cidadãos".

Nesta dissertação adotaremos a idéia de participação social de VALLA, considerando aspectos de protagonismo. A etapa a ser estudada será a da formulação do Projeto Bertioga Município Saudável.

\section{Sociedade Civil / Estado: novos posicionamentos}

A concepção de sociedade civil data do século XIX, com base no conceito de comunidade de Rousseau, uma comunidade concreta de cidadãos soberana, uma vez que o poder era considerado efetivamente do povo. Na verdade, a comunidade do século XIX se reduziu a uma agregação competitiva de interesses particulares, suporte da esfera pública; 0 indivíduo era suporte da esfera privada e constituinte básico da sociedade civil (SOUZA SANTOS 1995, p. 81).

Para DEMO (1988, p.29), em tese, o Estado deveria ser a organização da sociedade civil em função dos seus interesses. Na prática, a sociedade civil não teria um controle sobre o Estado, que representaria somente a parte dominante da sociedade, devido à desorganização da população.

O Estado, para SOUZA SANTOS (1995, p. 117), distintamente da sociedade civil, seria uma criação artificial e moderna que, por meio de um sistema jurídico unificado e centralizado, comunicar-se-ia com a sociedade civil.

De acordo com a visão desse autor, o dualismo Estado/sociedade civil é marcado por contradições que dificultariam a análise dos processos 
de transformação social do fim do século $X X$. Entre essas contradições, SOUZA SANTOS (1995, p. 123) apontou o desempenho de funçōes, antes confiadas somente ao Estado, por organizações da sociedade civil. Outro aspecto salientado é a debilidade da sociedade civil diante da esfera pública, especialmente em paises periféricos e semiperiféricos, fato que dificulta ainda pensar numa junção dessas duas esferas num plano teóricoprático.

Para DEMO (1988, p. 29-30), não se deveria distinguir sociedade civil de Estado, pois há momentos em que a sociedade faz parte do Estado e momentos em que está fora ou até em uma posição de enfrentamento. É o caso dos funcionários públicos, que fazem parte da máquina estatal $\mathrm{e}$, ao mesmo tempo, participam de seu sindicato classista.

Numa visão hegemônica, a sociedade civil seria composta, no fundo, por uma massa desigual e desorganizada da população (DEMO, 1988, p. 30).

GOHN (1997, p. 301-2) propõe uma nova concepção de sociedade civil para o nosso país, que amplia a relação Estado-sociedade, onde se reconhece a atuação das chamadas ONGs no papel de mediadoras entre coletivos de indivíduos organizados $e$ as instituições do sistema governamental. Além disso, a autora percebeu, na sociedade brasileira, um conceito mais coletivo de cidadania, onde se reconhecem os conflitos e os atores sociais mais excluidos.

GOHN (1997, p. 303) também reconheceu que os movimentos sociais brasileiros tiveram um papel importante na construção de novas relações com o Estado, bem como diferentes formas de participação Conforme JACOBI (1989, p.10), os movimentos sociais urbanos funcionam como agentes que estabelecem um equilíbrio de forças diferenciado entre 0 Estado e a sociedade civil. 
Em sintese, as relações entre sociedade civil e Estado determinam avanços ou recuos na resolução de conflitos, no estabelecimento de formas de participação, e podem contribuir na reconstrução de um tecido social fragmentado.

No próximo item, será delimitado um quadro conceitual relacionado aos conflitos e movimentos sociais.

\section{"Velhos e Novos" Movimentos, Conflitos e Atores/Sujeitos Sociais}

Com referência a um contexto europeu, para entender a origem dos novos movimentos sociais, temos de rever os "velhos paradigmas" dominantes após a II Guerra Mundial, centrando-nos em seus quatro componentes principais (valores, temas, atores e práticas institucionais) e comparando-os com o novo paradigma, partindo das mesmas categorias (OFFE, 1994). Os temas-chave daquela época foram o crescimento econômico, a distribuição e a seguridade, desenvolvendo confitos relacionados aos padrões do Estado de Bem-Estar e à reprodução material. Os novos conflitos surgem em áreas ligadas à reprodução cultural: a integração social e a socialização. Está ligada "à gramática das formas de vida (....) Esses conflitos seriam entendidos como uma resistência a tendências de colonizar o mundo da vida" (HABERMAS, 1981). A nova politica pressupõe questōes como os problemas de qualidade de vida, igualdade, realização individual, participação, direitos humanos (HABERMAS, 1981; OFFE, 1994,) e teria apoio principalmente de uma nova classe média, da juventude e de grupos com um maior nivel de instrução.

SCHERER-WARREN (1996 p. 23-24) destaca novos elementos culturais presentes tanto nos movimentos "tradicionais" (velhos movimentos 
sociais") como nos surgidos mais recentemente ("novos movimentos sociais). Elementos étnicos e de cultura política como o comprometimento com a descentralização a autonomia, o respeito à diversidade cultural e humana, paz com justiça social respeito à natureza, democracia mais direta e participativa, ajudam a conectar e formar uma rede de movimentos.

No Brasil, essa diferenciação entre uma nova e velha política não se fez de modo tão aparente, já que a América Latina teve um processo histórico diferenciado (GOHN 1997).

Para melhor compreender a natureza dos conflitos sociais em torno das velhas e novas temáticas, recorreremos às análises de alguns autores.

FERREIRA Lúcia da Costa (1998, p. 1) considerou o aspecto coletivo nos conflitos sociais:

\begin{abstract}
Conflitos dizem respeito à formação de atores sociais. Ou, em outros termos, aqueles agrupamentos coletivos capazes de reinventar a sociedade, de acordo com seus próprios planos e de acordo com uma estratégia de atuação pactuada. (....) Os conflitos carregam em si o germe da transformação social. Se há dois atores em disputa, isso significa que outros tantos conseguiram se entender acerca de alguma coisa. E é essa maravilhosa capacidade de agrupamento de sujeitos em busca do bem comum, e a coragem de lutar por ele, que está na base da emergência de um conflito social.
\end{abstract}

Para TOURAINE (1989, p. 16), os conflitos são dirigidos contra a ordem, pois ela esconde interesses divergentes sobre aquilo que está em jogo. Para ele $(1985$, p. $750-1)$, os movimentos sociais podem ser concebidos como um tipo especial de conflito social, pois é um modo de auto-organizar os grupos sociais. Um conflito pressupõe uma clara definição do ator, a definição de seus oponentes e das regras, isto é, da totalidade cultural que define o campo do conflito, os recursos pelos quais estejam lutando ou negociando o controle. 
FERREIRA Lúcia da Costa $(1998$, p. 3) diferenciou movimentos sociais de grupos políticos de pressão e grupos de interesses coletivos. Nos grupos políticos de pressão não haveria interdependência entre as forças políticas e decisões políticas. Seriam um tipo de mobilização social circunstancial, sem fôlego para transformação dos sujeitos que deles fazem parte, por meio da ação. Nos grupos de interesse coletivo, os atores estariam centrados em si mesmos e o campo do conflito seria definido independentemente dos atores.

A Sociologia dos Movimentos Sociais e, de um modo geral, a Sociologia da Ação, definem os atores sociais com base em suas estratégias, papéis e sua relativa influência nos processos de mudança (TOURAINE 1985, p. 768).

Para abordagem dos movimentos sociais existem outros conceitos, que diferem da concepção no item anterior. SADER $(1988$, p. 55$)$ preferiu trabalhar a noção de sujeito em vez de utilizar termos como ator social, agente, e explicitou que sujeito coletivo seria "uma coletividade onde se elabora uma identidade e se organizam práticas através das quais seus membros pretendem defender seus interesses e expressar suas vontades, constituindo-se nessas lutas."

Num contexto brasileiro, SADER (1988) expôs que alguns significados como a identidade de um grupo, originado de uma posição, o modo de articular objetivos práticos e valores do grupo e a vivência de algumas experiências que possibilitam ao grupo reconhecer seus objetivos, seus inimigos, e o mundo que 0 envolve, são fundamentais para a compreensão da dinâmica das ações dos movimentos sociais.

Com relação à questão da ligação desses agrupamentos e à conceituação de classes sociais, SADER (1988) distinguiu que os novos movimentos sociais dar-se-iam no solo da condição proletária, mas de um 
modo tal que os contornos classistas se diluiriam. Considerou, ainda, a emergência dos novos atores sociais ou novos sujeitos políticos quando emerge "uma matriz discursiva capaz de reordenar os enunciados, nomear aspirações difusas ou articulá-las de outro modo, logrando que indivíduos se reconheçam nesses novos significados" (SADER 1988, p. 60).

SADER (1988) não considerou que a origem dos movimentos sociais urbanos no Brasil, da década de 1970, podia somente ser explicada pela exposição das "condições dadas", decorrentes do sistema social: os padrões da acumulação capitalista com suas fatias de superexploração para tantos e vantagens para outros, o desenvolvimento urbano (ou sua crise), as condições do chamado "milagre brasileiro". Conforme ele, a origem dos movimentos sociais está nas mediações simbólicas que os grupos fazem entre as carências e os valores que partilham num determinado momento e também com as experiências anteriores de mobilização de suas lideranças. Ele observou que os diferentes movimentos sociais seriam identificados pelo tipo de ações para alcançar seus objetivos, tanto quanto pela importância relativa atribuída aos diferentes bens materiais e simbólicos que reivindicam.

Outro conceito importante para nossa análise é o de sujeito social, diferente de sujeito coletivo, definido por SCHERER-WARREN (1996, p. 15) como sendo "a relação de responsabilidade e de auto-criatividade positiva, não destrutiva, que $o$ indivíduo estabelece consigo mesmo e com a sociedade em que vive". Dessa forma, na sua relação com outros sujeitos, os indivíduos deixariam de ser meros elementos do sistema social para serem produtores de uma nova sociedade.

Para a compreensão da mobilização dos diversos atores sociais em Bertioga, a contribuição de SADER é extremamente valiosa. No entanto, para compreender a forma e as possibilidades de envolvimento de novos atores sociais no Projeto Bertioga Município Saudável, é necessário focalizar 
as práticas políticas articulatórias das ações localizadas, as redes de iniciativas elou movimentos.

No próximo item, será apresentada uma das novas formas como se organizam os movimentos sociais, as ações coletivas e as iniciativas locais a organização de redes de apoio social.

\section{Redes, Ações Coletivas e Movimentos Sociais}

Encontramo-nos em um período denominado pós-moderno, caracterizado por profundas mudanças tecnológicas. DOWBOR $(1998, p .10)$ destacou algumas tendências que estruturam o nosso futuro, tais como a tecnologia e a globalização, que redefinem a noção de tempo e de espaço. Para o autor, as novas tecnologias de informação tais como a Internet, por exemplo, permitem uma comunicação instantânea e horizontalizada. Há uma mundialização da economia, da mídia e de uma série de outras áreas.

Mudanças também ocorrem no plano da configuração da sociedade que adota novos conceitos como flexibilidade, descentralização, intercomunicação horizontal e redes para se adaptar a essa nova conjuntura (SCHERER-WARREN 1996 p. 8).

De acordo com SCHERER-WARREN (1996, p. 20), há duas visões sobre a questão da organização da sociedade civil nesse período pósmoderno.

Uma primeira visão detecta uma desmobilização, um imobilismo ou um antimovimento por parte dos movimentos sociais, caracterizados pela desorganização e um profundo processo de exclusão social. A segunda visão, baseada em uma reflexão crítica sobre os movimentos sociais, aborda novas perspectivas para esse estudo (SCHERER-WARREN 1996 p 22-1). 
Se em períodos anteriores esse estudo priorizava a macroanálise do social (décadas de 1950, 1960 e 1970) e o estudo das microtransformaçōes (década de 1980), agora surge a preocupação de articular estas duas dimensões, isto é, a conexão do local com o regional, o municipal, o nacional e o global (SCHERER-WARREN 1996, p. 22).

O conceito de rede vem sendo utilizado nos últimos anos, tanto como conceito teórico ou metodológico quanto por atores sociais para se referirem a uma relação ou prática social (SCHERER-WARREN 1999, p. 21).

Do ponto de vista de uma análise conceitual de redes, existem abordagens antropológicas e sociológicas. A abordagem antropológica define rede como uma parte já existente de um sistema social. $A$ abordagem sociológica tem como perspectiva que as redes se originam em um tecido social comunitário, ou em um tecido social mais amplo, sendo que, neste caso, os elos são familiares ou de amizades ou ideais religiosos e políticos comuns (NADEL, 1957, apud SCHERER-WARREN 1999, p. 24; DEROYPINEAU 1991, apud SCHERER-WARREN,1996, p. 25).

Já Melucci (1989), citado por SCHERER-WARREN (1999, p. 26), considerou que as redes são áreas de movimento, onde pequenos grupos que compartilhem de uma identidade coletiva, possam interferir em politicas públicas.

A integração dessas idéias origina a seguinte sintese, proposta por Diani (1992), citado por SCHERER-WARREN (1999, p. 26): “Um movimento social é uma rede de interações informais entre uma pluralidade de indivíduos, grupos e/ou organizações, engajados num conflito político ou cultural, com base numa identidade coletiva comum"

Essa estratégia de organização visa a conseguir (SCHERERWARREN, 1999, p. 28): 
- Relações políticas mais horizontalizadas, sugerindo novos modelos de representação política.

- Conexão do local com o global, ou do especifico com o citadino; dessa maneira, problemas de um bairro são tão importantes como as questões que envolvem um município ou região.

As redes de movimentos tendem a atuar na formação de novos valores ligados sobretudo à democracia $e$ às necessidades de sobrevivência (SCHERER-WARREN, 1999, p. 121-2). Nesse aspecto, ocorre uma sintonia com os valores propostos pelo movimento de municípios/cidades saudáveis. 


\section{CAPÍTULO 3}

OBJETIVOS DA PESQUISA 
Esta dissertação tem os seguintes objetivos:

\section{Geral}

- Analisar a participação da sociedade civil na formulação e implementação do Projeto Bertioga Municipio Saudável.

\section{Especificos}

1. Identificar e caracterizar o tecido social de Bertioga, isto é, os diversos atores sociais, movimentos sociais e grupos/organizações/instituições, seus interesses, necessidades e sonhos em relação ao município de Bertioga, durante as negociações, na formulação e implementação do Projeto Bertioga Município Saudável.

2. Identificar problemas e sua causalidade do ponto de vista dos diferentes atores, grupos sociais organizados e segmentos da sociedade de Bertioga.

3. Analisar os efeitos decorrentes do uso de metodologias participativas no protagonismo dos diversos grupos sociais de Bertioga e a possibilidade de sua articulação em rede, inclusive com o poder local. 


\section{CAPÍTULO 4 \\ CENÁRIO DO ESTUDO: \\ BERTIOGA}


A Estância Balneária de Bertioga está localizada no litoral do Estado de São Paulo (ver Anexo 1), numa região denominada de Região Metropolitana da Baixada Santista da qual, além de Bertioga, fazem parte outros oito municípios: Cubatão, Guarujá, Itanhaém, Mongaguá, Peruibe, Praia Grande, Santos e São Vicente. Os municípios circunvizinhos de Bertioga são os municípios de Guarujá, Santos, Mogi das Cruzes, BiritibaMirim, Salesópolis e São Sebastião (ver Anexo 2).

Segundo RIBEIRO $(1999$, p. 3), o termo Bertioga tem origem na palavra Buriquioca em tupi, sendo que buriqui, para os indios, significa macaco, e oca quer dizer casa, morada; portanto Buriquioca significa morada dos macacos.

RIBEIRO (1999, p. 4), ao relatar a história de Bertioga, escreveu que a mesma iniciou-se por volta de 1531, quando Martim Afonso de Souza atracou suas naus nas águas de Buriquioca. Nos séculos XVII e XVIII, intensificou-se a caça à baleia em Bertioga, com a finalidade de extração de óleo destinado à iluminação pública e particular.

Até a década de 1940, a população de Bertioga era basicamente de pescadores (RIBEIRO 1999, p. 4). A partir dos anos 1950, e particularmente nos anos 1970, a ocupação da região de Santos, que incluía o atual município de Bertioga foi intensificada por grandes investimentos no setor secundário e de construção civil, além do incremento do turismo na região (BAENINGER e SOUZA 1994). Data dessa época a construção do trecho da Rodovia Rio-Santos (BR-101) que liga São Sebastião a Bertioga. Em 1985, foi construída a Rodovia Mogi-Bertioga (SP-98), aumentando ainda mais 0 fluxo de turistas.

Dessa maneira, os efeitos do crescimento regional no município foram sentidos apenas posteriormente, por meio do aumento da população de 
Bertioga de uma forma não planejada e fragmentada em seus aspectos socioeconômicos. Essa fragmentação, de origem histórica, baseada no processo de ocupação da faixa litorânea paulista, caracterizou-se por uma mobilidade não planejada. Por um lado, a mobilidade dos turistas de veraneio de grandes centros, que construíram sua segunda residência em luxuosos conjuntos imobiliários; de outro, a mobilidade daqueles que sofreram um processo de exclusão social em suas terras de origem, tendo sido forçados a migrar em busca de melhores condições de vida e que, por falta de opções, estabeleceram moradia em locais impróprios, os quais se transformaram em favelas; e, finalmente, uma população flutuante, equivalente em muitas vezes à população residente, denominada de turista de um dia, que freqüenta a cidade em finais de semana. Essa mobilidade constitui-se num desafio a uma territorialidade, contrapondo-se à desterritorialidade existente.

Segundo o censo de 2000 do IBGE (2000), a população atual de Bertioga é de 30.619 habitantes, sendo que 29.178 vivem na zona urbana e 861 na zona rural. A população residente, com dez anos ou mais, em Bertioga, é de 23.756 habitantes, ou seja, cerca de $22,41 \%$ da população mora a menos de dez anos em Bertioga.

Segundo dados do IBGE e da Fundação Seade (SEADE, 2000), o municipio de Bertioga foi um dos que apresentaram maior crescimento demográfico na região no periodo entre 1991 e 2000, 11,70\% ao ano. Em 1996, a taxa geométrica de crescimento anual da população de Bertioga era de $8,33 \%$ ao ano. Nesse mesmo ano, as mesmas taxas referentes à região administrativa de Santos e do Estado de São Paulo eram de 1,44\% a.a. e $1,58 \%$ a.a., respectivamente (IBGE 1996).

Ainda segundo a Fundação Seade, em 2000, a taxa de analfabetismo da população adulta era de $8,26 \%$, enquanto que na Região Metropolitana de Santos esta taxa era de $6,27 \%$ (SEADE 2000). 
Devido a tal situação demográfica, o município carece de uma infraestrutura adequada, que suporte essa pressão populacional, ainda que temporária. De acordo com dados da Sabesp, em 1999, 13\% da população estava abastecida com ligações de esgoto.

Por ser um município novo ainda, a construção de uma identidade e sensação de pertencimento está para ser constituida. RIBEIRO (1999) considera que, nos seus 500 anos, Bertioga sempre foi encarada como um lugar de passagem ou de pouso, e não como local de fixação e moradia.

O municipio de Bertioga baseado em seu PDDS/Bertioga - Plano Diretor de Desenvolvimento Sustentado de Bertioga, Lei Municipal $n^{\circ} 315 / 98$ é dividido em cinco áreas geomorfológicamente: Região I-Caiubura, Região II - Centro, Região III - Indaiá, Região IV - Costa do Sol e Região V Boracéia.

Segundo descrição de PEREIRA (2001), a região de Caiubura abrange a porção oeste do território urbano de Bertioga, desde a divisa com Santos até o eixo do Rio Itapanhaú, limitando-se ao norte com o Parque Estadual da Serra do Mar, a linha de alta tensão da CODESP, o eixo do Rio Jaquareguava e o eixo do Rio Itapanhaú. Esta região é ocupada por chácaras e unidades de habitação de baixa densidade.

A região do Centro compreende a parte territorial urbana situada entre o eixo do Rio Itapanhaú e uma via que passa na lateral dos parcelamentos do solo denominados "Jardim Vista Linda" e "Chácaras Vista Linda", estendendo-se da praia até o Rio Itapanhaú, aos fundos. Essa região poderia ser subdividida em quatro áreas: A) Centro ( Vicente de Carvalho; B) Centro / Chácara; C) Centro / Vila e D) Centro / Vista Linda. 
A área Centro / Vicente de Carvalho situa-se ao norte da BR-101, tem início no rio Itapanhaú e possui características apropriadas, segundo define - PDDS, para abrigar população de baixa renda, desde que entremeada com áreas propícias para práticas náuticas fluviais. Desta sua área faz parte o assentamento "irregular" "Vicente de Carvalho" .

A área Centro / Chácara engloba área ao norte da BR-101 terminando no Rio Itaguaré, e engloba o parcelamento "Chácaras Vista Linda".

A área Centro / Vila, abriga o centro histórico de Bertioga (Forte São João), e possui o maior índice de ocupação, e tem início no Rio Itapanhaú e término na linha que determina propriedade do SESC- Bertioga, junto ao "Maitinga", ao sul do traçado da Rodovia Rio- Santos e possui população e parcelamentos diversificados e heterogêneos, todos com médio e alto valor agregado, passando por antigos parcelamentos do solo, como o "Vila Tupy", "Vila Itapanhaú", até os mais modernos condomínios "Centerville" e Boungainville"s, e usos os mais diversificados, como hotéis, restaurantes, serviços, shopping-center, comércio varejista, oficinas, além de sediar o Pronto- Socorro e Hospital municipais, a Câmara de Vereadores e a própria Prefeitura Municipal. Ocorre a substituição de usos de antigas unidades de habitação para uso comercial/serviços, edificação de novas unidades de habitação nos condomínios e no "Maitinga", construção de prédios, flatservices, hotéis e pousadas e ainda outros edifícios para fins comerciais e de prestação de serviços. Abriga também marinas e garagens náuticas ao longo do Canal de Bertioga.

A área Centro / Vista Linda estende-se do "Maitinga" até o loteamento "Jardim Vista Linda", englobando o "Jardim Vista Alegre", "Jardim Raphael", "Jardim das Canções" e demais parcelamentos bastante semelhantes em configuração e forma de ocupação. 
A região do Indaiá pode ser sudividida em três áreas: A) Indaiá / Itapanhaú; B) Indaiá / Hanga-Roa e C) Indaiá / Riviera.

A área Indaiá / Itapanhaú compreende limite entre a Zona de Suporte Náutico situada na área Centro / Vicente de Carvalho e o Rio Itaguaré, contendo o loteamento denominado "Chácaras Itapanhaú", núcleo de subhabitação denominado "Mangue Seco", próximo ao Rio Itapanhaú e vasta área ainda sem ocupação.

A área Indaiá / Hanga- Roa é formado por uma região também ao sul da BR-101, desde o loteamento "Jardim Vista Linda" até a "Riviera de São Lourenço" e que engloba também, o loteamento "Jardim Indaiá" e suas diversas glebas, pequenos parcelamentos, com exceção apenas do condomínio "Hanga-Roa", empreendimento de um público alvo com maior poder aquisitivo.

A área Indaiá / Riviera é formada pelo loteamento denominado "Riviera de São Lourenço", "Jardim São Lourenço" e "Itaguaré", além de

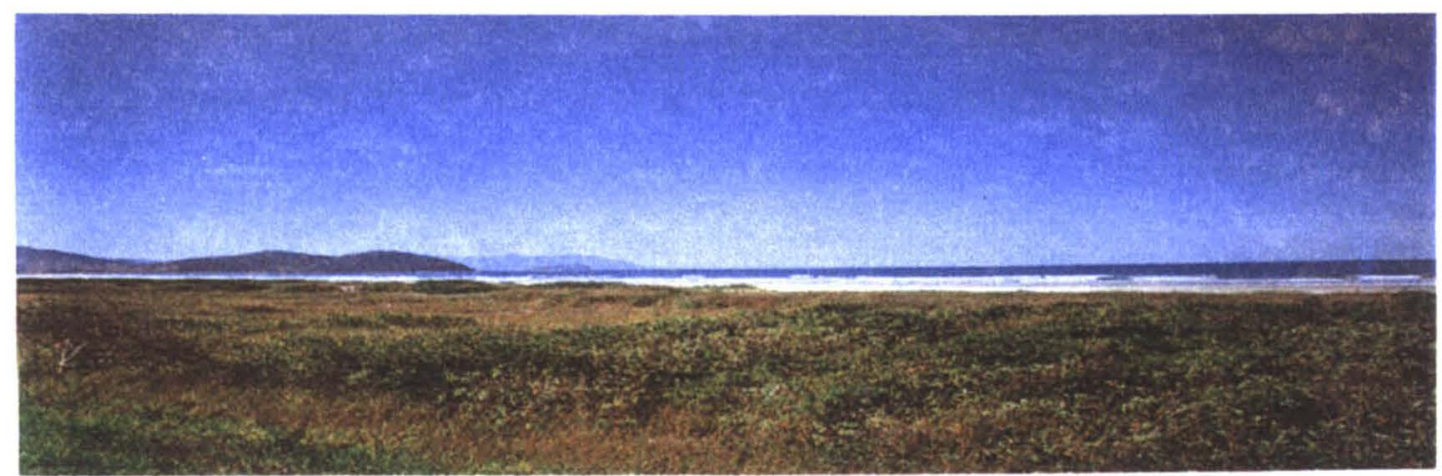

FOTO 1: PRALADE TIAGUARE

glebas disponiveis para futuros empreendimentos e possui certa semelhança tipológica, exceção ao São Lourenço, gleba 1, originalmente um autêntico núcleo caiçara englobado no empreendimento, e que abriga população, em sua maior parte, de origem bertioguense desde longa data. 
A Riviera destaca-se em relação aos demais empreendimentos imobiliários do litoral norte e de Bertioga em particular, pela excepcional oferta de serviços e sua qualidade ambiental.

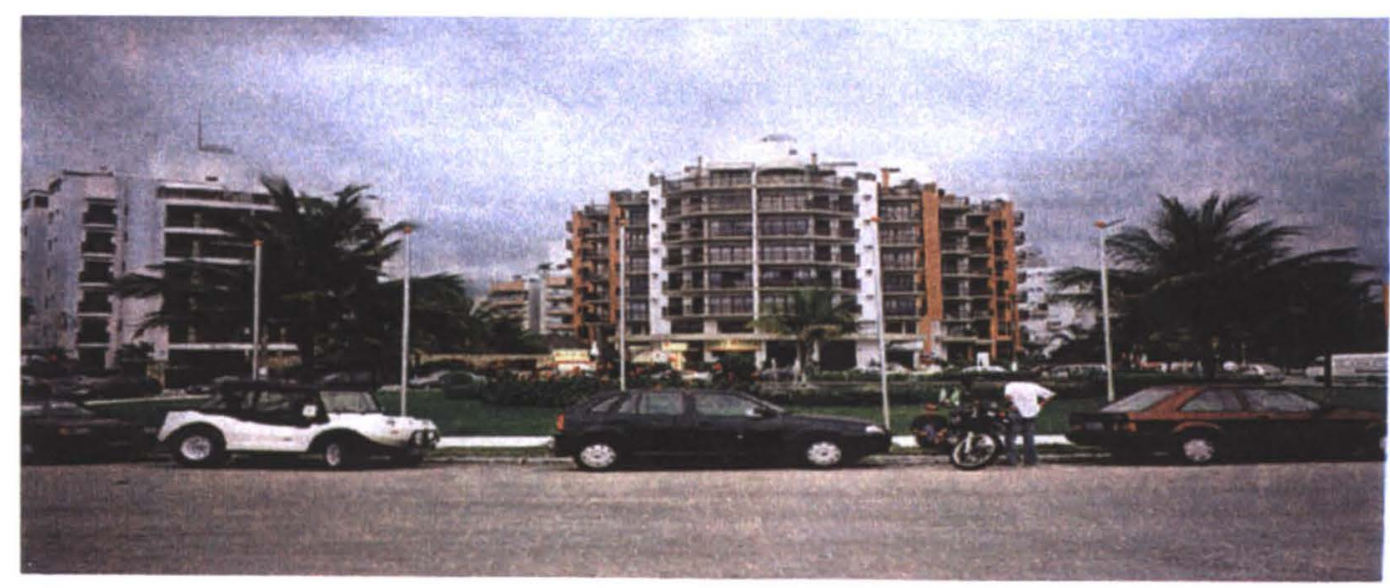

FOTO 2: CONDOMINIO RMIERA DE SĀO LOURENÇO

A região da Costa do Sol possui seu início no Vale do Rio Itaguaré e se estende até $o$ vale do Rio Guaratuba, num limite determinado por uma linha imaginária que passa $\mathbf{4 0 0}$ metros ao norte da linha de alta tensão da CESP, compreendendo um espaço com baixa densidade populacional, alto coeficiente de áreas verdes e de preservação e que inclui os empreendimentos "Guaratuba" e "Costa do Sol".

A região Boracéia possui início no Rio Guaratuba e término junto aos limites com o municipio de São Sebastião, limitando-se ao norte por uma linha que acompanha o Rio Vermelho e Ribeirão Pedra Branca e por uma linha ideal com inicio na foz do Ribeirão da Anta no próprio Ribeirão Pedra Branca e término na divisa São Sebastião no ponto de cruzamento da linha de alta tensão da CESP. 
Abriga lotes diversificados, tais como "Morada da Praia" e "Balneário Mogiano", diferentes em termos de ocupaçảo, o primeiro com uma população mais homogénea, num parcelamento do solo servido por boa infra estrutura, mas que apresenta drenagem precária e a ocupaçăo irregular em direção ao complexo Serra do Mar. O loteamento Balneário Mogiano, muito antigo, datado do inicio da década de 50, e seu prolongamento, o "Chácaras Mogiano", nảo possui infra estrutura, nem vias totalmente abertas.

Há um assentamento indigena, a Aldeia Indigena Guarani do Rio Silveira, administrada pela FUNAI, próximo à divisa com Săo Sebastiảo com 948 hectares.

Com o objetivo de realizar uma pesquisa exploratória que será descrita posteriormente, e a organizaçăo de um banco de dados dos participantes das atividades, o municipio foi dividido em cinco regióes que serăo detalhadas no momento do relato do histórico do projeto.

O municipio, por ser recém emancipado, teve a gestăo de dois prefeitos até o presente momento. O terceiro prefeito eleito está em seu segundo ano de mandato.

A escolha de Bertioga foi pautada pelos seguintes critérios:

1. Caracteriza-se como um projeto piloto de Municípios/ Cidades Saudáveis com participação da Universidade, do poder público e da populaçăo.

2. O projeto está sendo acompanhado desde o seu início e, dessa forma, ocorre a possibilidade de desenvolver todas as atividades de formulação, implementação e avaliação dos resultados. 
3. O município possui características que já foram mencionadas anteriormente, que se constituem em um desafio para toda a equipe.

4. Outro fator que favoreceu o inicio deste projeto foi o compromisso e disposição do poder público local, representado pelo prefeito da gestão anterior e seus secretários, de participar e implantar o projeto no municipio, respeitando a lógica intersetorial e com participação social. 


\section{CAPÍTULO 5}

\section{CONSTRUINDO O MUNICÍPIO SAUDÁVEL POR MEIO DE PESQUISA-AÇÃO PARTICIPANTE}




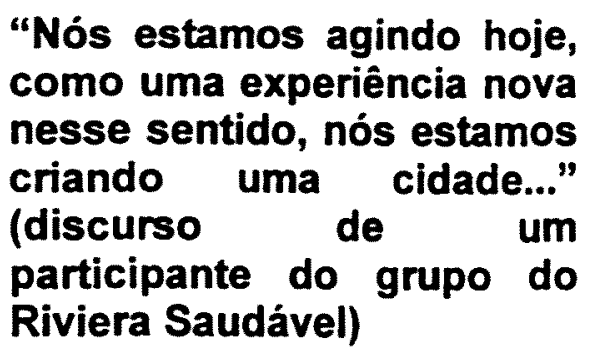

A concepção, o planejamento, a implementação e a avaliação de um projeto município saudável pressupõe uma metodologia que investigue a realidade de um município e, simultaneamente, consiga mobilizar e envolver seus participantes para uma inserção dentro do projeto.

Por ser um projeto de pesquisa, ao mesmo tempo de intervenção e avaliação, a metodologia adotada para este estudo foi a da pesquisa-ação. Como escolha metodológica, a pesquisa-ação foi a opção neste trabalho por ser a mais adequada para operacionalizar os resultados dos processos de resolução de problemas e tomada de decisões na implantação do Projeto Bertioga Município Saudável, considerando situaçōes de relacionamento entre variáveis conhecidas (objetivos do projeto, açōes dos pesquisadores) e variáveis desconhecidas (contexto histórico-social de Bertioga).

A descrição da metodologia será feita em três etapas: na primeira etapa serão feitas considerações gerais sobre aspectos metodológicos considerados na concepção do projeto e na sua implantação; em um segundo momento será descrita a metodologia e as técnicas desenvolvidas durante o processo de diagnóstico, sensibilização e coleta de dados; e numa terceira etapa será descrita a metodologia que foi utilizada para realizar a análise de todo material coletado.

Segundo THIOLLENT (1985, p.7-25) a pesquisa-ação: 


\begin{abstract}
é uma metodologia de pesquisa social orientada em função da resolução de problemas ou de objetivos de transformação ou ainda, um método ou estratégia de pesquisa agregando vários métodos ou técnicas de pesquisa social, com os quais se estabelece uma estrutura coletiva, participativa e ativa ao nivel da captação de informação. (THIOLLENT, 1985, p. 7-25).
\end{abstract}

Neste caso, as pessoas e os grupos envolvidos nos problemas têm um papel ativo no equacionamento, no acompanhamento e na avaliação das ações desencadeadas em função dos problemas, conjuntamente com os pesquisadores.

Os pesquisadores também podem ter um papel ativo dentro de uma estratégia denominada de intervenção social, pois, muitas vezes, as propostas iniciais são elaboradas por um pequeno grupo de agentes externos, mas "da interação entre análise de problemas sociais e estratégias para enfrentá-los, suas aplicações e acompanhamentos de desempenho, surge um novo conhecimento". (TASSARA, 1996, p. 56).

Este novo conhecimento pode ser gerado por meio de relatos de estudos em intervenção, comprometidos com uma linha de tratamento descritivo histórico-social,

uma linha descritiva que processando-se em torno do histórico da evolução de um ciclo unitário completo social, isto é, a que o mesmo visa solucionar, e englobando processos de planejamento, implementação e, implicitamente, o comportamento político do pesquisador. (TASSARA, 1996, p. 58).

O desafio em uma intervenção social consiste na ampliação e no envolvimento de novos atores sociais para que as transformações desejadas não fiquem restritas em um pequeno grupo de intelectuais - as denominadas vanguardas (TASSARA \& RABINOVICH, 2001, p. 212).

Um fator a ser considerado é que os programas de pesquisa de intervenção social têm limitações como projetos de conhecimento, pelo fato 
de que a realidade que se quer conhecer - interações entre intervenções e desempenho social - sofre a contínua influência de outras forças sociais, em nivel estrutural e conjuntural, além da intervenção em si (TASSARA, 1996, p. 59). Entretanto, por meio de meticulosos planejamento, acompanhamento, registro e avaliação das atividades interativas, nos quais intervêm 0 conhecimento empírico da população e o conhecimento científico dos técnicos de pesquisa de intervenção, é impossivel que um novo conhecimento não seja produzido.

'É inegável que a metodologia proposta tem relação com as intenções concretas dos pesquisadores envolvidos. No caso, a intenção de sensibilizar e envolver a população em processos de resolução de problemas e tomada de decisões. Este fator da esfera subjetiva tem "influência nos programas de intervenção em relação a uma situação histórico-social específica" (TASSARA, 1996, p. 59). A sensibilização dos individuos em espaços adequados desencadeia a expressão de suas subjetividades, relacionadas com o ambiente urbano em que vivem (TASSARA \& RABINOVICH, 2001, p. 213).

$\mathrm{Na}$ análise dessas subjetividades, dentro de um contexto de espaço e tempo, é possível construir um panorama das aspirações dos moradores de uma localidade, pois se respeitam valores tradicionais, transmitidos de geração em geração (ibidem, p. 214).

O autor da pesquisa teve um envolvimento durante todo o processo desencadeado no primeiro ano de atividades do Projeto Bertioga Município Saudável no papel de observador participante. Este papel foi exercido como coordenador de campo da Pesquisa Exploratória, coordenador e relator das Oficinas regionais e do Futuro, e como coordenador e observador de diversas reuniões para planejamento de discussão do projeto. 
Algumas observações colocadas nesta dissertação são o resultado dessa observação participante. Segundo HAGUETTE (1987 p. 67) a observação participante apresenta riscos de quanto a neutralidade $e$ objetividade cientifica, devido à relação entre observador / observados e uma impossibilidade de generalização dos resultados.

De qualquer maneira esse aspecto não desvaloriza algumas informações e conhecimentos obtidos através desse procedimento.

\section{Critérios para Decisão sobre a Temporalidade (Corte) a ser estudada}

Para delimitar a temporalidade referente à análise, faremos uma breve abordagem do que Rist (1994), citado por CONTONGS \& SPRINGETT (1997), considerou como fases do ciclo de um processo político relacionado à área da saúde: a política de formulação, a política de implementação e a política dos resultados.

Os autores mencionados consideram que o modelo de RIST(1994) possibilita a avaliação de um processo de desenvolvimento de uma política no campo da saúde. Cada fase pode ser avaliada separadamente, com sua própria politica e seus atores.

A Organização Mundial da Saúde (WHO/ Europe 1997) estabelece três fases para o desenvolvimento de um projeto de Cidades/Municípios Saudáveis: fase (1) iniciando a ação, fase (2) organizando e fase (3) agindo.

A fase 1 denominada de "Iniciando a ação tem por objetivo principalmente a sensibilização das pessoas a serem envolvidas no projeto. Esta fase consiste de 6 passos. 
1. Aumentar a consciência sobre a saúde e as condições para mantê-la ou recuperá-la;

2. Divulgar e sensibilizar sobre a idéia inovadora de município saudável;

3. Mobilizar os diferentes setores de governo e da sociedade civil para pensar em uma ação intersetorial;

4. Encorajar e fortalecer a participação comunitária;

5. Assegurar, com as organizações governamentais e não-governamentais, o compromisso com políticas públicas saudáveis.

6. Orientar os interessados para pensarem em elaborar um planejamento estratégico.

A fase 2 chamada de "Organizando" prepara as condições para o funcionamento e gestão do projeto e compõe-se de cinco passos.

1. Formar uma comissão intersetorial responsável pelo projeto;

2. Estabelecer a relação entre situação de saúde diagnosticada e as condições de vida da população;

3. Montar um escritório;

4. Desenvolver uma agenda para a cidade;

5. Capacitar pessoas para o projeto.

E fase 3 denominada de "Agindo" inicia efetivamente as ações de desenvolvimento da agenda proposta para a cidade. Esta fase consiste de três passos.

1. Ampliar e organizar o conhecimento sobre a cidade;

2. Identificar possíveis parceiros para o projeto;

3. Execução da agenda para a cidade.

As três fases não são segue absolutamente uma seqüência linear podendo ocorrer simultaneamente. Algumas desses passos podem se repetir durante todo o desenvolvimento do projeto. 
Na concepção de CONTONGS \& SPRINGETT (1997), não há uma clara divisão dos limites de cada fase, constituindo-se muito mais num ciclo de fases que se interpõem e se sucedem. O Projeto Bertioga Municipio Saudável teve inicio, oficialmente, no estabelecimento do protocolo de intençōes entre a USP e a prefeitura, mas sua fase de implementação ainda está ocorrendo neste ano de 2002, apesar de já haver alguns resultados visiveis.

Para efeito desta análise, será considerada a fase de implementação do projeto delimitada no seu início pela primeira oficina de sensibilização e, no seu final, pela formação da Comissão Intersetorial, logo após o 1 Seminário Municipal do Projeto Bertioga Municipio Saudável.

\section{Aspectos práticos da pesquisa-ação}

De acordo com THIOLLENT (1987, p. 48-72) a concepção e a organização de uma pesquisa-ação abordaria um roteiro com os seguintes aspectos práticos:

1. A fase exploratória em que se descobre o campo de pesquisa, os atores sociais a serem envolvidos e suas expectativas e 0 estabelecimento dos problemas prioritários e eventuais ações.

2. O tema da pesquisa que é a designação do problema prático a ser abordado.

3. A colocação dos problemas consiste em definir uma problemática, isto é, um campo teórico e prático em que se pretende resolvê-los. 
4. O lugar da teoria no qual se gerariam idéias, hipóteses ou diretrizes para orientar a pesquisa e sua interpretação.

5. Hipóteses como uma suposição formulada pelo pesquisador a respeito de possíveis soluções a um problema colocado na pesquisa no nivel observacional.

6. Seminário em que os membros da equipe de pesquisadores e membros significativos se reúnem para examinar, discutir e tomar decisões acerca do processo de investigação.

7. Campo de observação, amostragem e representatividade qualitativa é um momento em que se define o campo (área) a ser observado, o tamanho e os critérios da amostra para a pesquisa.

8. Coleta de dados em que se utilizam entrevistas coletivas ou individuais, técnicas documentais e técnicas de grupo.

9. Aprendizagem em que se estimula um processo de aprendizado dos participantes através de restituição da informação, formas de discussão e processos de negociação.

10. Saber formal dos pesquisadores e saber informal (da população), que têm como objetivo a melhoria da comunicação entre esses dois universos.

11.Plano de ação em que se elabora uma forma de ação planejada, que deve ser deliberada, realizada e avaliada.

12. Divulgação externa, momento no qual a informação adquirida pode ser retornada aos grupos implicados. 
Pode-se prever que esses aspectos, algumas vezes, ocorrem simultaneamente e não seguem necessariamente uma ordem préestabelecida.

Nesse contexto, algumas atividades desenvolvidas durante o primeiro ano de formulação, implementação e avaliação do Projeto Bertioga Município Saudável coincidiram com aspectos práticos da pesquisa-ação listados no roteiro anterior.

Algumas atividades como a pesquisa exploratória, as oficinas de sensibilização e as oficinas do futuro foram o eixo desse primeiro ano de atividades realizadas em Bertioga, e tiveram como pressuposto básico fomentar e garantir a participação social, como forma de, passo a passo, estimular o protagonismo e a apropriação do projeto pela sociedade civil de Bertioga. Este processo revelou-se, também, como uma base de uma futura sustentabilidade do projeto no sentido de sua manutenção, mesmo com mudanças políticas dentro do município.

Ao mesmo tempo em que se procurou sensibilizar os participantes, houve a intenção de construir um conhecimento coletivo acerca dos problemas, potencialidades, causalidade dos problemas, atores sociais envolvidos nos problemas e, numa etapa mais avançada, a elaboração de propostas coletivas de resolução de alguns problemas priorizados.

Para efeito de descrição da metodologia utilizada durante o processo de diagnóstico, sensibilização e coleta de dados, será feita uma abordagem descrevendo inicialmente as técnicas utilizadas na Pesquisa Exploratória, nas Oficinas de sensibilização (Primeira Oficina de Sensibilização e Oficinas Regionais de Sensibilização) e nas Oficinas do Futuro. Posteriormente será feita uma descrição da metodologia para a realização da análise de todo material coletado. 


\section{Pesquisa exploratória}

A pesquisa exploratória fundamentou-se na utilização do protocolo para o levantamento do tecido social que, no tocante à metodologia, seguiu recomendações de BARROS (1998) e FEURSTEIN (1986). Esta etapa corresponde aos aspectos práticos (1), (2) e (3) de THIOLLENT (1987) para a definição dos problemas prioritários e sua problemática.

O protocolo segue as seguintes fases:

-Amostragem intencional

-Instrumentos

-Seleção e treinamento dos entrevistadores

-Pré-teste e estudo piloto

-Logística

-Material

-Processamento e análise de dados

-Aspectos éticos

\section{Amostragem intencional}

Este momento corresponde aos aspectos (6) e (7) mencionados por THIOLLENT (1987) em que se define o espaço amostral, o tamanho da amostra e os critérios de sua escolha.

Pelo fato de o espaço de amostra ser constituído de lideranças comunitárias, representantes de grupos e instituições, a escolha foi baseada na indicação, obtida de informantes "chave" do próprio local, sendo a seleção intencional. $O$ tamanho da amostra não foi determinado de antemão e dependeu das circunstâncias e das indicações recebidas a cada dia, do entrevistador e da área da entrevista. 


\section{Instrumentos}

O instrumento principal foi o formulário (ver Anexo 3), que foi aplicado individualmente e respondido oralmente. Quanto à elaboração do formulário, levou-se em conta sugestōes apontadas por METTRICK (1993), como linhas gerais a serem consideradas: objetivos da pesquisa, layout, pré-codificação das respostas, clareza e precisão, relevância, antecipação de problemas, brevidade.

A escolha da entrevista corresponde ao aspecto (8) citado por THIOLLENT, referente à coleta de dados.

\section{Selecão e treinamento dos entrevistadores}

A seleção foi realizada com base em critérios definidos pela equipe local, em conjunto com a equipe da Universidade de São Paulo. O treinamento foi realizado com base em recomendaçōes de FEURSTEIN (1986), por meio de simulações do trabalho de campo, envolvendo alguns aspectos como apresentação da equipe, formulação das perguntas e registro das respostas. Esta fase corresponde ao aspecto (9) apresentado por THIOLLENT (1987), referente a um processo de aprendizagem.

\section{Pré-teste e estudo piloto}

O pré-teste foi feito de forma a testar a eficácia do formulário, sua clareza, condições para o preenchimento e tempo de duração da aplicação. O estudo piloto foi realizado em um dia a fim de realizar o último teste da metodologia e do instrumento a ser aplicado em campo. 


\section{Logística}

A logística foi definida em conjunto com técnicos da prefeitura e pesquisadores da Universidade de São Paulo e incluiu questões como meios de locomoção dos pesquisadores, alimentação e sistemas de comunicação.

\section{Material}

Listagem de todo material necessário à realização da pesquisa que incluiu: formulários, pranchetas, canetas, lápis, borrachas, crachás de identificação, termos de consentimento (ver Anexo 4), pastas com elástico e cadernos de anotação.

\section{Processamento de dados}

Foi realizada uma sistematização quantitativa e qualitativa, com base no que foram definidas categorias para análise posterior dos dados. Os dados categorizados foram digitados no programa Microsoft Access e formaram um banco de dados para processamento.

Quanto à organização dos resultados dos questionários, foi possivel visualizar quatro conjuntos de temas. $O$ primeiro, referiu-se à caracterização dos entrevistados e dos grupos, entidades $e$ instituiçōes aos quais pertencem. O segundo, foi a visão de problemas, aspectos positivos e sonhos que os entrevistados possuem com relação à Bertioga. $O$ terceiro conjunto visualizado foi o conjunto de indivíduos e instituições consideradas parceiras e referências no município. $O$ quarto bloco demonstrou a disposição dos entrevistados quanto à participação nas futuras Oficinas Regionais de sensibilização sobre o Projeto Bertioga Municipio Saudável. 0 terceiro e o quarto blocos não serão apresentados nesta dissertação. Esta etapa corresponde aos aspectos (4) e (5) mencionados por THIOLLENT 
(1987), nos quais se geram idéias e hipóteses para orientar a pesquisa e sua interpretação.

Os resultados foram sistematizados em tabelas referentes a: a) problemas citados pelos entrevistados; b) aspectos positivos de Bertioga mencionados pelos entrevistados; c) sonhos dos entrevistados para Bertioga; d) grupos, entidades, organizaçōes e instituiçōes de Bertioga. Inicialmente, foi feita uma listagem de todas as respostas separadas pelas cinco regiōes. Algumas respostas coincidentes foram agrupadas estabelecendo um ranking provisório. Em seguida, essas respostas foram categorizadas considerando os seguintes critérios: a) Foi feito um ranking geral para todo o município de Bertioga; b) Foram feitas algumas categorias para agrupar algumas respostas, porém, sem perder a percepção de algumas respostas e itens mais peculiares; c) Algumas respostas foram agrupadas, mas considerou-se que, separadas, possibilitariam um maior detalhamento da análise; d) Algumas respostas foram deixadas fora das categorias por não serem suficientemente claras; e) o número de ocorrências/citações é algumas vezes superior ao número de entrevistas devido aos entrevistados citarem mais do que um problema, um aspecto positivo, um sonho ou grupo / entidade / organização / instituição.

\section{Aspectos éticos}

Para cada entrevistado foi explicado claramente o objetivo da pesquisa e solicitada sua permissão para a realização da entrevista. Ao aceitar a entrevista, o entrevistado assinou um termo de consentimento livre e esclarecido. 


\section{Oficinas de sensibilização}

Estas atividades iniciaram o processo de sensibilização envolvendo maior parcela da população. A proposta metodológica de todas as oficinas foi baseada em um enfoque participativo, por meio do qual se procurou a interação dos participantes, de forma a favorecer a liberdade de expressão. Esta etapa corresponde ao aspecto (8) citado por THIOLLENT (1987), de uma coleta de dados por meio de um processo grupal.

No campo da psicologia comunitária, LANE (1963), citado por BONFIM (1999, p. 100), pontuou que, na comunidade, o "agente externo" :

trabalha fundamentalmente com a linguagem e representaçöes, com relaçöes grupais - vinculo essencial entre o individuo e a sociedade - e com as emoçōes e afetos próprios da subjetividade, para exercer sua ação a nivel da consciência, da atividade e da identidade dos individuos que irão, algum dia, viver em verdadeira comunidade.

BONFIM (1999) reafirmou a importância de alcançar a identidade comunitária ou de grupo por meio da expressão de emoções e sentimentos. A autora destacou o papel que algumas abordagens, como a dinâmica de grupo, dramatização, círculos de cultura, biodança e trabalhos com argila, têm na deflagração das emoçōes - subjetividade - para o fortalecimento de um grupo e de sua identidade.

Todas as atividades desenvolvidas durante as oficinas tiveram este componente emocional.

Outro aspecto considerado e valorizado foi o princípio da obtenção de consensos, em que as diferenças culturais, territoriais $e$ individuais foram consideradas de extrema importância. Os trabalhos em grupo e as plenárias, além da habilidade dos moderadores, favoreceram o estabelecimento de resultados e produtos consensuais nas oficinas. Este processo relaciona-se 
ao aspecto (9) mencionado por THIOLLENT (1987), no qual ocorre uma processo de aprendizado.

Os instrumentos utilizados para a realização das oficinas foram uma ficha de inscrição (ver Anexo 5) para cada participante, um roteiro para a relatoria das oficinas e um pôster com o resultado da Pesquisa Exploratória . Os dados e informações obtidos por intermédio desses instrumentos permitiram sistematizar o perfil de seus participantes e suas percepções sobre o município de Bertioga.

As oficinas foram desenvolvidas basicamente em quatro momentos. Em cada oficina as atividades foram realizadas procurando seguir uma seqüência de momentos: (1) aquecimento do grupo; (2) atividade de reflexão / elaboração, apresentação do resultado de cada grupo; (3) sistematização e visualização dos resultados, síntese e apresentação dos conceitos teóricos; e (4) avaliação.

No primeiro momento (1), as atividades iniciais de aquecimento foram propostas com o intuito de criar um clima favorável à integração dos participantes e estimular a reflexão e a criatividade.

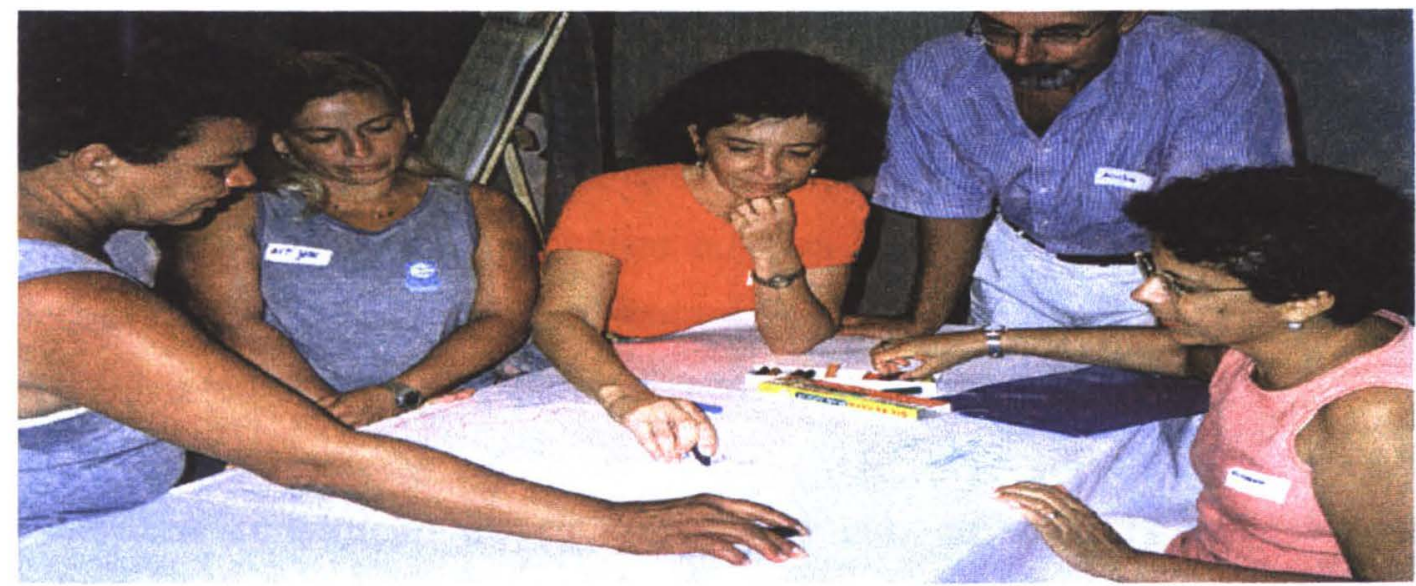

FOTO 3: DESENHO COM GR DE CERA-OFICINA DE SENSIBILZAÇÃO 
No segundo momento (2), nas atividades de elaboração e reflexão, foram utilizadas técnicas que favoreceram o envolvimento dos participantes, inclusive o emocional, como o desenho com lápis de cera, música e sucata para a construção do que seria a Bertioga hoje, e a Bertioga saudável, isto é, a Bertioga desejável para o futuro.

Diversas técnicas pedagógicas trabalham com a construção do conhecimento coletivo. O Psicodrama, por exemplo, é uma técnica que fundamenta uma prática de ação, que tem a espontaneidade como seu conceito mais importante (ROMAÑA, 1992, p. 50). Trabalha dentro de seu repertório jogos em que "o paciente mostra como imagina o seu futuro e através da valorização do que pode ocorrer nesse futuro é possivel que ele se torne um profeta de si próprio" (MORENO, 1966, apud CRELIER, 1993, p. 85).

Segundo ROMAÑA (1992, p. 60-1), ao utilizar uma situação psicodramática para fins educacionais, poderemos avançar por três movimentos possiveis para a compreensão de uma situação ou realidade: análise, síntese e generalização.

Ao pedirmos que os participantes colocassem suas versões sobre a cidade no presente, o resultado foi uma construção realista ou uma análise. Ao pedirmos que os participantes construíssem com a sucata essa mesma cidade, o resultado foi simbólico ou uma síntese. E no caso de pedir que construam a cidade como gostariam que fosse no futuro será a construção de uma fantasia ou uma generalização (ROMAÑA 1992, p. 62).

A construção da cidade com o uso da sucata, proposta destas oficinas, representou a materialização de um psicodrama com a utilização de objetos intermediários. A essência da técnica com a sucata permitiu ir ao mundo da fantasia, possibilitando aos seus participantes "viajarem" pelo mundo do imaginário e, assim, recriarem e descobrirem novas formas de 
enxergar a cidade. Estas técnicas possibilitaram a identificação da percepção dos participantes sobre os problemas e necessidades sentidas em relação ao município de Bertioga, sem restrição à emergência de sentimentos e emoções. Foi a libertação da subjetividade.

BORDENAVE (1980 p. 73) referiu-se ao método do arco de Charles Maguerez, no qual, no processo de ensino-aprendizagem, os participantes de um trabalho devem ser levados em um primeiro momento a observar a realidade com seus "próprios olhos". Se isto não pode ser feito literalmente por meio de uma visita in loco, meios audiovisuais, modelos, podem trazer essa realidade até seus participantes. $O$ trabalho com sucata conseguiu cumprir essa finalidade.

Conforme esse autor, em um segundo momento os participantes devem problematizar, isto é, os pontos-chave do problema, as variáveis mais determinantes da situação. Em um terceiro momento deveriam teorizar ou se perguntar os porquês da situação observada, isto é, sua causalidade. Em um quarto momento, caso haja compreensão da causalidade dos problemas, haveria a elaboração de hipóteses para a solução dos mesmos. O quinto momento seria para a aplicação dessas hipóteses.

O método do arco é retomado em sua quase totalidade durante as oficinas do futuro.

DEL RIO (1991, p. 3) cita GIBSON (1966), que considerou a percepção como:

um processo mental de interação do indivíduo com o meio ambiente que se dá através de mecanismos propriamente ditos e, principalmente, cognitivos. Os primeiros são dirigidos pelos estímulos externos, captados através dos cinco sentidos, onde a visão é o que mais se destaca". "Os segundos são aqueles que compreendem a contribuição da inteligência, uma vez admitindo-se que a mente não funciona apenas a partir dos sentidos e nem recebe essas sensações passivamente; existem contribuições do sujeito ao processo perceptivo desde a motivação à decisão e conduta"(MOORE \& GOOLEDGE, 1976; FISKE \& TAYLOR, 1991, apud DEL RIO, 1991, p. 3). 
Esses mecanismos cognitivos incluem motivações, humores, necessidades, conhecimentos prévios, valores, julgamentos e expectativas.

Os trabalhos em grupo, as plenárias para a problematização e outros processos consensuais ajudaram a socializar a discussão, de modo que as percepções individuais dessem lugar a uma percepção coletiva relativamente comum.

A visualização dos resultados, com base em sua sistematização, foi primordial para a socialização da discussão em plenária, que valorizou a opinião de cada participante e facilitou a construção de um conhecimento coletivo do grupo. Além disso, trouxe subsídios para a elaboração dos relatórios e constituiu um produto da oficina, sendo retomado em oficinas posteriores.

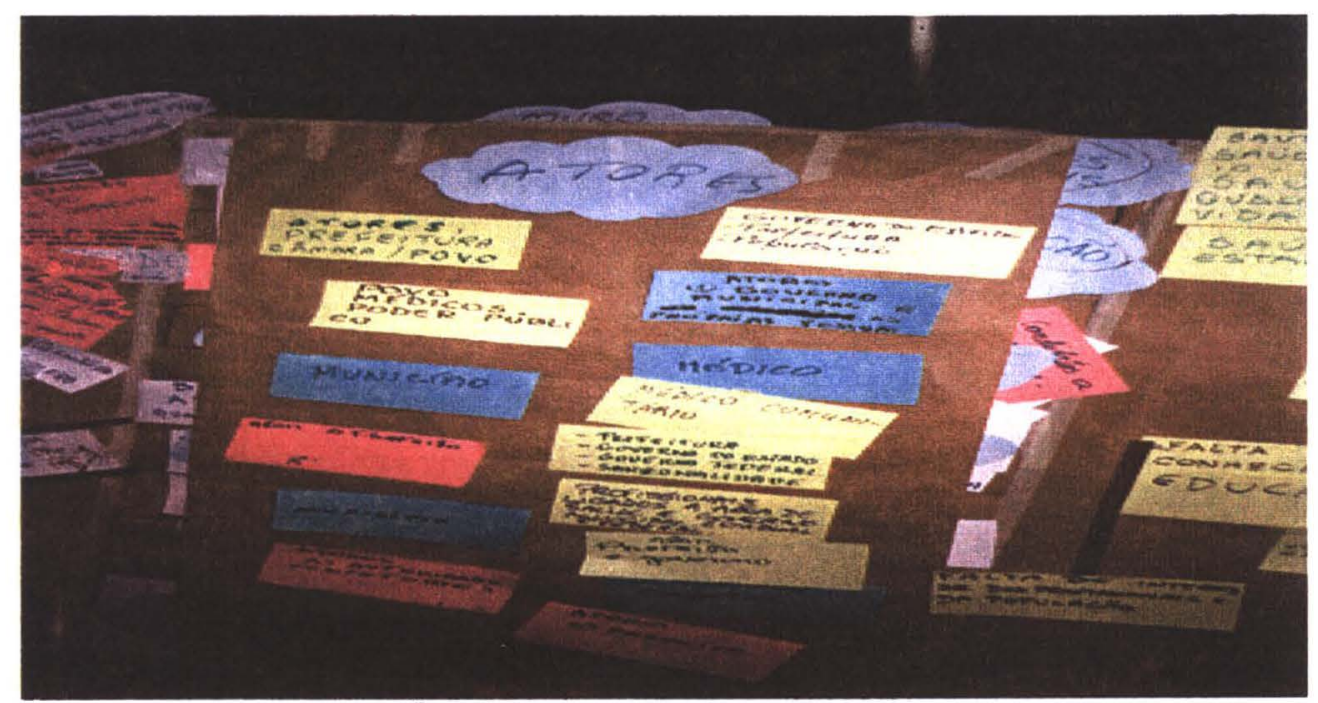

\section{FOTO4: VSUALRAÇÃODOS ATORES SOCLAIS}

No terceiro momento (3), foi realizada uma síntese das apresentações dos participantes, acrescida da apresentação dos pressupostos teóricos, que dão suporte para o movimento Cidades/Municípios Saudáveis. Esses pressupostos permitiram a revisão do senso comum sobre a realidade local, 
mas houve também a revisão dos conceitos pela apreensão da realidade, permitindo a construção de um novo conhecimento. Este momento corresponde ao aspecto (9) e (10) mencionado por THIOLLENT (1987), no qual ocorre uma troca de informações dos pesquisadores com a população.

E, no quarto momento (4), a avaliação permitiu o aperfeiçoamento de cada oficina e o desenvolvimento de um senso crítico dos participantes quanto ao conteúdo e metodologia utilizados.

Os roteiros da $1^{\circ}$ Oficina de Sensibilização e das Oficinas Regionais estão anexos (ver Anexos 6 e 7)

\section{Oficinas do Futuro}

A oficina do futuro fundamenta-se nos princípios da pesquisa-açãoparticipativa (VIEZZER, 1993), da intervenção educacional, por intermédio de projetos para a solução de problemas (TASSARA, 1996), bem como no Tratado de Educação Ambiental para Sociedades Sustentáveis e Responsabilidade Global (1992).

É uma técnica participativa utilizada para o levantamento de problemas e potencialidades/sonhos de uma comunidade, que pode ser incluída entre as técnicas de trabalho grupal. As oficinas do futuro utilizaram técnicas de pesquisa-ação associadas a outras técnicas participativas (KRAPPITZ et alli, 1987, PREFEITURA MUNICIPAL DE SÃO PAULO, 1997), que apresentam as seguintes características:

- A idéia básica da técnica é, com base no levantamento de problemas e sonhos da comunidade local, construir uma agenda de prioridades e açōes locais de modo participativo. 
- Alguns dos elementos básicos nos quais se baseia o enfoque são: visualização móvel por meio do uso de tarjetas, problematização, alternância entre plenária e trabalho individual ou em grupo, avaliação contínua, ambiente adequado, registro e documentação.

- O roteiro básico das oficinas segue a seguinte seqüência: identificação dos problemas, determinação das causas dos problemas e atores sociais envolvidos, detalhamento das inter-relações entre atores e priorização dos problemas a serem trabalhados.

- O produto final das oficinas é a elaboração de uma agenda prevendo um plano de ações, metas, objetivos, responsabilidades, parcerias, prazos, recursos monitoramento e avaliação.

O instrumento utilizado para a realização das oficinas foi uma ficha de inscrição (semelhante à utilizada nas Oficinas Regionais) para cada participante. Os dados e informações obtidos com base nessas fichas permitiram sistematizar o perfil de seus participantes.

O procedimento básico da $1^{\circ}$ oficina foi o seguinte:

1. Construção do "Muro das Lamentações", onde cada participante escreve ou desenha em uma tarjeta algum problema referente ao local onde mora e, então, pendura esta tarjeta no muro. Esta etapa corresponde à observação da realidade no método do arco.

\section{FOTO 5: MURO DAS LAMENTAÇÕES EÁRVORE DOS SONHOS}

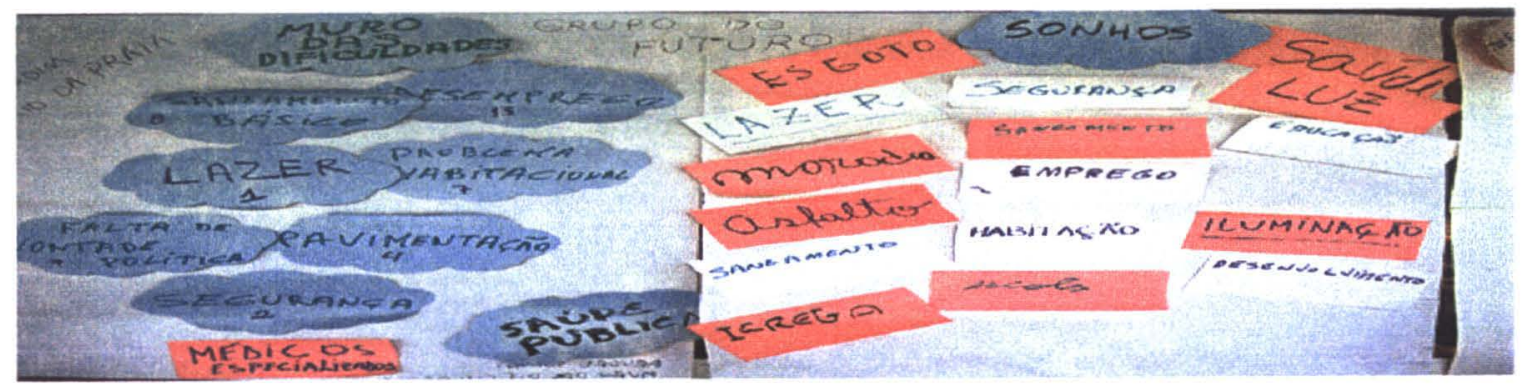


2. "Problematização", que consiste na colocação de perguntas por parte do moderador para a mobilização de idéias, das experiências e os conhecimentos de todos os participantes, a fim de revelar a complexidade dos problemas. Esta etapa se refere à identificação de pontos-chave dos problemas no método do arco.

3. "Agrupamento dos problemas semelhantes", constituindo-se alguns conjuntos de problemas.

4. "Escolha dos problemas prioritários" a serem trabalhados.

5. Construção da "Árvore da Esperança", que segue os mesmos passos $(1,2,3$ e 4$)$ do "Muro das Lamentações", porém ao invés de problemas são escritos ou desenhados os sonhos nas tarjetas, sua discussão, seu agrupamento e sua priorização.

Estas oficinas correspondem aos aspectos (1), (2), (3), (8), (9) e (11), citados por THIOLLENT (1987), e diferenciam-se das atividades anteriores por proporem um plano de ação para a resolução de alguns problemas priorizados pelos grupos. É o momento que os grupos podem avançar da sensibilização para uma ação.

Cabe aqui ressaltar o conceito que Mendes atribuiu ao termo problema como sendo

\begin{abstract}
a formulação para um ator social de uma discrepância entre a realidade constatada ou simulada e uma norma aceita ou criada como referéncia". Em outras palavras, é a identificação de uma diferença entre 'o que é' e o que 'deveria ser', de acordo com padrōes e valores considerados desejáveis do ponto de vista de um ator social. (MENDES et alli, 1993).
\end{abstract}

PIKE \& SELBY $(1999$, p. 33) destacaram a dimensão temporal e consideraram que o futuro não é previsível ou predeterminado, mas pode ser modificado pelos individuos. Dessa forma a realidade desenvolve-se a partir 
do passado, mas é também "modelada pelo que se acredita à respeito do futuro" (SLAUGTHER, 1985, apud PIKE \& SELBY, 1999, p. 3). A partilha e a construção de sonhos coletivos também podem ser um fator de aglutinação e coesão de um grupo.

INGESTAM (1987) apud BUARQUE (1999) conceituou o planejamento como "instrumento de construção do futuro pelos atores sociais organizados como exercício do poder (da sociedade) sobre o futuro". Dessa forma as Oficinas do Futuro constituem-se em oficinas de planejamento participativo de um futuro desejável.

Assumir a participação social no processo de planejamento de um município saudável supõe a expressão das diversas demandas dos diferentes atores sociais, a garantia do acesso à informação, à existência de diálogo, à negociação e ao estabelecimentos de acordos. Dentro deste processo pode haver a busca pelo poder e a luta pelos interesses dos diversos atores sociais envolvidos. Alguns desafios políticos do planejamento, neste sentido, são (BUARQUE, 1999):

(1) Negociação de interesses entre as geraçōes atuais e futuras (apesar dessa geração ter pouca ou nenhuma representação).

(2) Articulação entre as necessidades imediatas e as de longo prazo.

(3) Conflito entre as decisões políticas e a racionalidade técnica.

(4) Multiplicidade e diversidade dos atores sociais, seus interesses e seus territórios.

Esses desafios implicam que, durante o processo, deva existir um elevado grau de flexibilidade, tolerância e capacidade na negociação de conflitos e diferenças de ponto de vista. Os conflitos, assim como a 
dinâmica por eles imprimida - que traz à tona diferenças ou desigualdades constituidas socialmente -, podem, dessa forma, criar a possibilidade de um aprendizado geral das pessoas envolvidas, já que se criam espaços de diálogo onde as idéias são expostas, discutidas, amadurecidas. Um outro conceito que emerge deste aspecto é que o planejamento é "um espaço de negociação entre os atores sociais confrontando interesses e alternativas" (BUARQUE, 1999).

Um dos aspectos a serem considerados na negociação de um grupo é a priorização coletiva com relação aos problemas a serem trabalhados. Com relação à priorização de problemas, Matus, citado por MIR (1990), afirmou que trabalhar por problemas exige, primeiro, uma explicação situacional que consistiria nos seguintes pontos: uma clara explicação do que define o problema, uma análise da cadeia causal do problema, o estabelecimento do espaço de um problema para delimitar seu âmbito explicativo e a identificação dos nós críticos da cadeia causal. Durante as oficinas apenas alguns desses aspectos foram tratados.

Posteriormente à primeira oficina, houve continuidade por meio de outras oficinas, prevendo a determinação das causas dos problemas e responsabilidade dos atores sociais envolvidos, o detalhamento das interrelações entre atores e 0 estabelecimento de um plano de ações. Estas oficinas correspondem às etapas de teorização, elaboração de hipóteses e aplicação na realidade do método do arco.

O roteiro dessas oficinas, com a descrição de suas técnicas, encontra-se anexo (ver Anexos 8, 9 e 10).

Para analisar as percepções dos participantes quanto à causalidade dos problemas, iremos remeter às noçōes de representação social e coletiva DURKHEIN (1963), que foi o primeiro a discutir representações sociais e 0 fez dentro do referencial positivista. Considerou o pensamento como reflexo 
da realidade e determinado por ela. Essas representações sociais seriam construídas e modificadas coletivamente mantendo uma certa autonomia em relação aos indivíduos. Não vamos adotar 0 entendimento de representações sociais de Durkhein.

MOSCOVICI, citado por HERZLICH (1988), reviu o conceito de DURKHEIN e considerou que a representação social não é reflexo da produção coletiva, mas uma construção mental de objetos, isto é na relação indivíduo-sociedade, se confere um signo à um objeto e passa-se a representá-lo. Esta concepção está mais de acordo com nossa visão de relação dos indivíduos com a sociedade.

BORDIEU, citado por JODELET (1986), trouxe mais um elemento para incluirmos em nossa concepção de representação social. Afirmou que a representação é uma maneira de restituir à subjetividade sua objetividade e pensar a relação entre 0 material e 0 imaterial. $E$ é isto que tentamos apreender dos dizeres dos sujeitos desta pesquisa.

Para estabelecer as relações de afinidade, oposição ou indiferença entre os atores sociais e grupos de interesse, foi utilizado um sociograma. $O$ sociograma é uma técnica baseada no sociodrama, na qual se utilizam objetos intermediários para a visualização de situações de conflito das classes ou em uma instituição como um todo ( ROMAÑA, 1992, p. 55).

\section{Coleta, registro e análise dos dados}

Para a coleta de dados durante as oficinas, foram feitas anotações e algumas gravações dos discursos dos atores sociais, para posterior sistematização. A qualidade das relatorias, de um modo geral, tanto das oficinas regionais como das oficinas do futuro, não manteve total fidelidade $e$ dependeu muito da atenção e da capacidade de registro dos relatores. A 
qualidade das gravações ficou prejudicada algumas vezes por ruídos externos como, por exemplo, ventilador ligado e, algumas vezes, pela distância do gravador da fonte emissora da palavra. Em algumas reuniōes foram utilizados dois gravadores. Alguns trechos não foram gravados devido ao esquecimento de ligar o aparelho ou algum problema técnico .

Para análise do processo de participação do periodo considerado na dissertação, foram consideradas as atividades realizadas que tiveram carga horária superior a três horas de duração e que tiveram algum registro consistente. Para analisar esse periodo, foram utilizadas informaçōes do banco de dados referentes à Pesquisa Exploratória, relatorias das Oficinas Regionais de sensibilização, relatorias e fitas gravadas das Oficinas do Futuro, relatórios das atividades realizadas, listas de presença e, posteriormente, entrevistas com os participantes.

Desta forma, foi feito um levantamento da presença dos participantes na $1^{\circ}$ Oficina de Sensibilização, na Pesquisa Exploratória, nas Oficinas Regionais, nas Oficinas do Futuro e no Seminário Municipal. Foi feito um levantamento das lutas dos grupos, organizações e instituições relacionadas a esses participantes, utilizando-se dos dados obtidos dos questionários aplicados na Pesquisa Exploratória. Procurou-se descrever as percepções dos participantes em relação aos problemas, sua causalidade e os sonhos para Bertioga sistematizando-se os relatórios e transcrições de fitas das Oficinas Regionais e Oficinas do Futuro. Analisou-se, também, o processo de resolução de "conflitos" durante as atividades desenvolvidas, especialmente durante as Oficinas do Futuro através da transcrição de fitas e posterior sistematização de seu conteúdo.

Para analisar esse processo de negociação e resolução de "conflitos" que foi permanente, foram selecionadas 14 Oficinas do Futuro de um total de 27 oficinas, sendo que 4 foram de um grupo do Rio da Praia (Grupo do Futuro), 3 de outro grupo do Rio da Praia (Grupos Novas Idéias, Antigos 
Problemas), 3 de um grupo de Boracéia (Guara-Bora Bora-Guara), 4 de um grupo de Riviera (Grupo Riviera Saudável), 1 de um grupo do Delphino (Grupo da Vila) e 1 de um grupo do Indaiá (Grupo Indaiá). Estas oficinas foram escolhidas, a princípio, pela qualidade de suas gravações e pela disponibilidade dessas transcrições.

O estudo das percepções dos participantes sobre a cidade estão relacionadas com a identificação do sujeito no espaço da cidade, tanto do ponto de vista daquilo que considera como aspecto positivo e daquilo que considera como problema. Os dados verbais registrados nos relatórios e gravações foram objeto de uma análise temática evidenciando os seguintes aspectos: problemas de Bertioga, aspectos positivos de Bertioga, causalidade de alguns problemas e questões conflituosas que surgiram durante as oficinas.

Como já foi mencionado, também foram realizadas entrevistas abertas de duração de cerca de 20 minutos cada, com roteiro prédeterminado (Anexo 11), com pessoas que participaram das oficinas. 0 objetivo das entrevistas foi apreender o efeito do uso de metodologias participativas no protagonismo de seus participantes.

Para todos os entrevistados foram esclarecidos os objetivos da pesquisa e garantido o anonimato. As entrevistas foram gravadas com 0 consentimento prévio dos participantes, que foram sorteados segundo 0 seguinte critério: um participante mais atuante e um menos atuante da Comissão intersetorial provisória (ver critérios nas Tabelas 4 e 5), um entrevistado da Pesquisa Exploratória, um participante das Oficinas Regionais e um participante das Oficinas do Futuro.

As fitas cassete foram transcritas e os aspectos mais relevantes foram destacados para a análise e interpretação final. As falas dos participantes 
foram colocadas no texto com a fonte de letra arial, com o tamanho de letra corpo 10 e alguns trechos negritados que são destaque do autor.

A análise e a interpretação final foram feitas por meio do cruzamento dos dados obtidos nos relatórios, entrevistas e documentos e no referencial teórico deste estudo.

No próximo capítulo, será feito um breve histórico de como ocorreu o primeiro período do Projeto Bertioga Município Saudável. 


\section{CAPÍTULO 6}

\section{DESENVOLVENDO O PROJETO}

BERTIOGA MUNICÍPIO SAUDÁVEL PRIMEIROS ACERTOS: $O$ COMPROMISSO DO MUNICÍPIO 
O relato a seguir é baseado de acordo com a metodologia descrita, em diário de campo, em atas e alguns outros registros escritos, procurando manter o máximo de fidelidade possivel. $\mathrm{A}$ tabela 1 mostra as principais atividades realizadas durante 0 ano de 2000 , com seus respectivos objetivos, datas, número de participantes e registros disponiveis. As primeiras iniciativas do Projeto Bertioga Município Saudável (PBMS) ocorreram a partir de uma solicitação do então secretário da Saúde de Bertioga. Em agosto de 1999, houve interesse da prefeitura deste municipio em uma assessoria da Faculdade de Saúde Publica da USP, para auxiliar na reorganização dos serviços de saúde.

$\mathrm{Na}$ ocasião, a Faculdade de Saúde Pública estava iniciando o desenvolvimento do eixo temático de promoção da saúde e estava interessada em experimentar na prática as possibilidades de desenvolver um projeto que considerasse a saúde de uma forma mais ampla, isto é, que impulsionasse a produção social de saúde, em conjunto com instituições e parceiros locais. A interdisciplinaridade e a participação de outras unidades da USP eram fundamentais. No final de agosto, o prefeito de Bertioga e seu secretário de Saúde compareceram à Faculdade de Saúde Pública, trazendo dados e informaçōes sobre 0 município, e resolveram assumir 0 compromisso de levar avante o projeto com um trabalho mais amplo, envolvendo todas as secretarias em uma perspectiva intersetorial. Nessa reunião ficou definido que, inicialmente, seria assinado um protocolo de intenções e, depois, um acordo de cooperação, e que 0 Instituto de Oceanografia apoiaria o projeto com base em um estudo das espécies marinhas. Com este acordo firmado, ficou acertado que seria desenvolvido um projeto piloto cidade saudável, onde se pudesse experimentar estratégias alternativas para a produção social da saúde. 


\section{Tabela 1 - Atividades realizadas durante o ano de 2000 pela Faculdade de Saúde Pública da USP}

\begin{tabular}{|c|c|c|c|c|}
\hline $\begin{array}{l}\text { Atividade } \\
\text { (Local) }\end{array}$ & $\begin{array}{c}\mathrm{N}^{\circ} \mathrm{de} \\
\text { participantes }\end{array}$ & Objetivo & $\overline{\text { Data }}$ & $\begin{array}{l}\text { Produtos } \\
\text { para análise }\end{array}$ \\
\hline Reuniāo preparatória (FSP) & Năo registrado & $\begin{array}{l}\text { Apresentaçáo de aspectos de Bertioga } \\
\text { pelo seu prefeito e secretário municipal }\end{array}$ & $30 / 08 / 1999$ & Ata da reuniăo \\
\hline Reuniåo preparatória (FSP) & 22 & $\begin{array}{l}\text { Apresentação da proposta do PBM S } \\
\text { aos secretários municipais e do esboço } \\
\text { do protocolo de intençóes }\end{array}$ & $03 / 12 / 1999$ & $\begin{array}{l}\text { Lista de } \\
\text { presença }\end{array}$ \\
\hline Oficina de sensibilizaçăo & 33 & Sensibilizaçáo & $\begin{array}{c}01 \mathrm{e} \\
02 / 03 / 2000\end{array}$ & $\begin{array}{l}\text { Relatório da } \\
\text { oficina }\end{array}$ \\
\hline Reuniåo Comissão Intersetorial & 15 & $\begin{array}{l}\text { Encaminhamentos da Oficina de } \\
\text { sensibilizaçăo }\end{array}$ & $21 / 03 / 2000$ & Ata da reuniāo \\
\hline Reunião Comissảo Intersetorial & 22 & Preparaçåo para Pesquisa Exploratória & $30 / 03$ & Ata da reuniăo \\
\hline Reunião com agentes de saúde & 15 & Preparaçăo para Pesquisa Exploratória & $06 / 04$ & \\
\hline $\begin{array}{l}\text { Treinamento para a pesquisa } \\
\text { exploratória }\end{array}$ & 19 & Treinamento & $06 / 04$ & \\
\hline Pesquisa exploratória & 134 & Diagnostico & $\begin{array}{c}07,08,09 \mathrm{e} \\
15,16 \mathrm{e} \\
17 / 04 / 2000\end{array}$ & Relatório \\
\hline Reuniào Comissāo Intersetorial & 26 & Preparaçáo das Oficinas Regionais & $12 / 06$ & Ata da reuniáo \\
\hline Reuniăo Comissảo Intersetorial & 16 & Nāo registrado & $10 / 07$ & Sem documento \\
\hline $\begin{array}{l}\text { Treinamento para as oficinas } \\
\text { regionais }\end{array}$ & Năo registrado & Treinamento & $04 / 08$ & \\
\hline Reuniāo Comissảo Intersetorial & 12 & Avaliação das Oficinas Regionais & $06 / 08$ & $\begin{array}{l}\text { Lista de } \\
\text { presença }\end{array}$ \\
\hline Reuniáo Comissāo Intersetorial & Nåo registrado & Nåo registrado & $21 / 08$ & \\
\hline Oficinas regionais & 160 & Sensibilização & 05 a 08/08 & Atas das oficinas \\
\hline $\begin{array}{l}\text { Apresentaçăo do projeto } \\
\text { temático }\end{array}$ & 52 & Sensibilizaçăo & $21 / 08$ & $\begin{array}{l}\text { Lista de } \\
\text { presença / Ata } \\
\text { da reunião }\end{array}$ \\
\hline $\begin{array}{l}\text { Oficina na Aldeia Guarani Rio } \\
\text { das Silveiras }\end{array}$ & - & Sensibilizaçăo & $05 / 09$ & Ata da oficina \\
\hline Reuniāo Comissão Intersetorial & 17 & $\begin{array}{l}\text { Avaliaçăo das Oficinas Regionais e } \\
\text { planejamento das Oficinas do Futuro }\end{array}$ & $11 / 09$ & Ata da reuniáo \\
\hline Reuniáo com facilitadores & 16 & Divulgaçāo & $11 / 09$ & $\begin{array}{l}\text { Lista de } \\
\text { presença }\end{array}$ \\
\hline Oficinas funcionários & 23 & Sensibilizaçåo & $14 / 09$ & \begin{tabular}{|l} 
Lista de \\
presença
\end{tabular} \\
\hline $\begin{array}{l}\text { Apresentação do projeto aos } \\
\text { candidatos }\end{array}$ & 47 & Sensibilizaçăo & $14 / 09$ & $\begin{array}{l}\text { Lista de } \\
\text { presença }\end{array}$ \\
\hline Oficinas professores & 28 & Sensibilizaçăo & $19 / 09$ & Ata da oficina \\
\hline Oficinas professores & Năo registrado & Sensibilizaçảo & $19 / 09$ & Sem documento \\
\hline Oncinas professores & 38 & Sensibilização & $20 / 09$ & Ata da oficina \\
\hline Ońcinas professores & Năo registrado & Sensibilizaçăo & $20 / 09$ & Sem documento \\
\hline Reuniåo com facilitadores & Nåo registrado & Divulgaçăo & $\begin{array}{c}\text { Năo } \\
\text { registrado }\end{array}$ & Sem documento \\
\hline $\begin{array}{l}\text { Preparaçăo das oficinas do } \\
\text { futuro }\end{array}$ & Nazo registrado & Treinamento & $25 / 09$ & Sem documento \\
\hline
\end{tabular}




\section{Continuacão - Tabela 1}

\begin{tabular}{|c|c|c|c|c|}
\hline Oficinas do futuro & 198 & $\begin{array}{l}\text { Construçao de uma agenda de } \\
\text { prioridades }\end{array}$ & $\begin{array}{l}\text { Outubro } \\
16 \text { dias }\end{array}$ & $\begin{array}{l}\text { Relatorio e fitas } \\
\text { gravadas }\end{array}$ \\
\hline $\begin{array}{l}\text { Reuniăo com Grupo Jardim } \\
\text { Paulista }\end{array}$ & Nảo registrado & Preparaçăo para o Seminário & $19 / 11$ & Sem documento \\
\hline $\begin{array}{l}\text { Reuniáo com Grupo Riviera } \\
\text { Saudável }\end{array}$ & Náo registrado & Preparaçáo para o Seminário & $20 / 11$ & Sem documento \\
\hline $\begin{array}{l}\text { Reuniāo com Grupo Novas } \\
\text { Idéias e Guará-Bora }\end{array}$ & Năo registrado & Preparaçáo para o Seminário & $25 / 11$ & Sem documento \\
\hline $\begin{array}{l}\text { Reuniảo com Grupo do Futuro e } \\
\text { Grupo Unidos do Indaiá }\end{array}$ & Náo registrado & Preparaçăo para o Seminário & $27 / 11$ & Sem documento \\
\hline Projeto de Avaliaçăo & - & Preparaçao para elaboraçāo do projeto & Várias & $\begin{array}{l}\text { Atas das } \\
\text { reunioes }\end{array}$ \\
\hline Seminário Municipal & 69 & Apresentaçáo das agendas & $09 / 12$ & Relatório \\
\hline
\end{tabular}

Houve, então, uma terceira reunião, no início de setembro, na qual participaram o prefeito e seu Secretário de Saúde e Bem-Estar do Município, a chefe do Setor de Vigilância Sanitária e Epidemiológica da prefeitura e um representante do Conselho Municipal de Saúde. Acertou-se, nessa ocasião, a viabilização da proposta de territorialidade utilizando, como base, dados do IBGE, com o objetivo de mudar o modelo de atenção à saúde do município. Ficou acertada também uma próxima reunião em Bertioga.

Na Faculdade de Saúde Pública formou-se uma equipe responsável pela elaboração de um plano inicial a ser desenvolvido em Bertioga. Dessa equipe faziam parte a Profa Marcia Wesphal, Emílio Telesi Júnior, Marco Ackermann, Cláudia Bógus, Rosilda Mendes, Ana Caricari, Paulo Capucci, Francisco Comarú e Victor Jun Arai. Dentre as primeiras tarefas a serem realizadas, destacaram-se as seguintes: fazer contato com as outras unidades da USP, elaborar um protocolo de intenções a ser firmado entre a Faculdade de Saúde Pública e a Prefeitura de Bertioga, a preparação da reunião a ser realizada em Bertioga e a elaboração de um projeto temático a ser desenvolvido com várias unidades da USP para enviar à Fapesp.

Em outubro daquele mesmo ano, a Organização Panamericana de Saúde - OPAS - Região Brasil apoiou a iniciativa, oferecendo auxilio financeiro para viabilizar o início da experiência. 
No inicio de dezembro de 1999, a equipe da Faculdade de Saúde Pública realizou uma reunião em Bertioga, da qual participaram o prefeito, seus secretários e outros funcionários da prefeitura, ocasião em que se apresentou a proposta que a Faculdade de Saúde Pública gostaria de desenvolver em Bertioga.

\section{Primeiros passos}

As atividades desenvolvidas durante o ano de 2000, em Bertioga, tiveram como objetivo principal fomentar a participação social por meio da sensibilização, com relação ao Projeto Bertioga Município Saudável e ao estímulo do diálogo entre o poder público e a sociedade civil.

Dentro desta lógica, as atividades foram dirigidas, ao mesmo tempo, para coletar informações e opiniões sobre os problemas, sonhos e ideais de uma cidade saudável, divulgar o projeto dentro do município, e fortalecer a articulação interna dos grupos envolvidos.

No início de março de 2000, foi assinado o protocolo de intençōes e realizada a primeira atividade de cooperação entre a Faculdade de Saúde Pública da USP e a prefeitura de Bertioga. Ocorreu a Primeira Oficina de Sensibilização intitulada Iniciando o Projeto Bertioga Município Saudável, com duração de 12 horas, cujo objetivo geral foi 0 de discutir os aspectos conceituais da promoção da saúde e de projetos por Municípios Saudáveis, visando à implementação do Projeto Bertioga Município Saudável como uma nova estratégia de gestão.

Os objetivos especificos dessa oficina foram: 
- Identificar a percepção sobre a relação entre promoção da saúde e o movimento Cidades/Municípios Saudáveis.

- Possibilitar discussões sobre descentralização, intersetorialidade, interinstitucionalidade, participação social, avaliação e sustentabilidade.

- Definir uma agenda de atividades iniciais a serem desenvolvidas, baseadas em um planejamento consensual de implantação do projeto no municipio.

O conteúdo programático definido foi:

1. Promoção da saúde e novo paradigma da saúde.

2. Promoção da saúde e o movimento de municipios saudáveis $/$ perspectivas mundiais e brasileiras.

3. Políticas públicas saudáveis definidas com base em uma estratégia de gestão intersetorial com participação social.

4. Elaboração de uma proposta de encaminhamento conjunto do Projeto Bertioga Município Saudável.

O principal resultado desta oficina foi a formação da Comissão Intersetorial Interinstitucional, de caráter provisório, de Bertioga. Esta comissão foi formada adotando-se um critério de representatividade de todos os setores da prefeitura e da sociedade civil presentes. Ficou, assim, constituída pelos seguintes membros: ( (1) Setor Saúde: Aluísio Bichir, Ana Maria Antunes, Eliana Avelino dos Santos, Lúcia M. Vasconcelos de Melo, Maurício Santos Souza; (2) Setor Turismo: Lais Helena Jacopucci; (3) Setor Meio Ambiente: Paulo Roberto Velzi, Mylene Lyra Pedroso; (4) "Cidadão": Aldo de Moraes; (5) Comunidade indígena: Márcio José do Nascimento; (6) 
Setor Juridico: Carla Regina Riesco; (7) Conselho Municipal de Saúde: Célia Regina Pereira e Miriam Costejan; (8) Universidade de São Paulo: Prof. Márcia Faria Westphal (titular) e Ana Maria Caricari (suplente).

Os principais objetivos da Comissão Intersetorial Interinstitucional estabelecidos foram: dar prosseguimento às atividades relacionadas ao PBMS, reforçar o compromisso do governo local com o PBMS e discutir os encaminhamentos da $1^{\circ}$ Oficina de Sensibilização.

Essa comissão era constituída pela maioria dos secretários municipais e por funcionários da prefeitura, além de representantes da sociedade civil e um representante da Universidade de São Paulo.

Ainda em março, foi realizada a primeira reunião conjunta entre a Comissão Intersetorial Institucional, a prefeitura municipal e a Faculdade de Saúde Pública. Nesta reunião decidiu-se que a comissão intersetorial e a prefeitura apoiariam o próximo passo do projeto, que seria a realização da Pesquisa Exploratória para conhecer o tecido social de Bertioga ao longo de todo território, para levantamento de problemas e sonhos das lideranças do municipio.

\section{Um Diagnóstico Inicial}

A Pesquisa Exploratória teve como objetivo geral identificar os atores sociais-chave, movimentos sociais, grupos de interesse e outros atores locais, que compōem o denominado tecido social do município de Bertioga. Considerou-se como tecido social as relações estabelecidas entre os atores referidos anteriormente, sua visão de mundo, suas representações sociais. 
Os objetivos específicos foram:

- Identificação de lideranças / grupos / organizações / instituições que atuam localmente.

a Formação de um banco de dados com nomes de possíveis parcerias e colaboradores para o Projeto Bertioga Município Saudável.

- Percepção das afinidades e conflitos entre as lideranças e grupos sociais.

- Mapeamento de repertórios socioculturais, por meio do levantamento dos problemas, aspectos positivos e sonhos.

- Mapeamento das possibilidades de locais para a realização de oficinas regionais.

a Conhecimento inicial dos territórios (e suas delimitações ).

Para a viabilização desta pesquisa foram realizadas duas reuniōes preparatórias com a Comissão Intersetorial, um treinamento com as agentes de saúde da prefeitura e com alguns estudantes universitários de São Paulo que acompanharam o trabalho. Nestas reuniōes foram definidas as seguintes questões:

1. Retomada dos objetivos e estratégia do levantamento / pequena discussão.

2. Definição das áreas para atuação das equipes de pesquisadores constituídas de duplas, áreas a serem percorridas, densidade populacional dessas áreas. Delimitação do número de áreas $\mathrm{e}$ estabelecimento de seus limites. 
3. Conversa sobre as possíveis dificuldades que poderiam ocorrer (horários de disponibilidade dos entrevistados, locomoção de uma área para outra, áreas de risco).

4. Escolha dos pesquisadores locais e definição dos critérios para a escolha: conhecimento da área, disponibilidade de horário, disposição para andar, ter leitura escrita, etc.

5. Data do treinamento.

6. Saída da equipe a campo para aplicação do pré-teste do instrumental.

Decidiu-se, nessas reuniões preparatórias, que as agentes de saúde fariam o trabalho de acompanhamento de toda a pesquisa devido à sua familiaridade com as áreas e o seu conhecimento sobre os moradores e lideranças. Após sugestão do secretário de Meio Ambiente, ficou acertado que o municipio de Bertioga seria dividido em cinco áreas (ver Anexos 12, $13,14,15$ e 16), para efeito da execução da pesquisa de campo, considerando-se sua extensão territorial e densidade populacional, denominadas de áreas I, II, III, IV, e V. As áreas definidas foram: Área I (A) Caiubura até 19 de Maio, correspondendo aos seguintes bairros/localidades: Chácara Caiubura, Sítio São João, Albatroz 2, Centro, até 19 de Maio e Vicente de Carvalho 2; Área II (B) - Vila Agaó até Ana Paula, correspondendo aos seguintes bairros/localidades: Vila Agaó, Maitinga, Rio da Praia, Mangue Seco, Jardim das Cançōes e Jardim Ana Paula; Área III (C) - Rafael até Indaiá, correspondendo aos seguintes bairros/localidades: Jardim Rafael, Vista Linda, Vista Alegre e Chácara Vista Linda; Area IV (D) Riviera até Costa do Sol, correspondendo aos seguintes bairros/localidades: Riviera, São Lourenço, Guaratuba e Costa do Sol; Área V (E) - Morada da Praia até Boracéia (próximo ao Balneário Mogiano) correspondendo aos seguintes bairros/localidades: Condomínio Morada da Praia, Boracéia, Canto do Itaguá, Balneário Mogiano e Aldeia indígena. 
Definiu-se, também, que seria realizado um treinamento, cujo objetivo seria o de capacitar os pesquisadores para identificaçăo de lideranças e a realização de entrevistas. 0 público-alvo consistiu nas 11 agentes de saúde de Bertioga e nos alunos da Faculdade de Saúde Pública, outros universitários e profissionais. $O$ treinamento foi realizado no inicio de abril, na sala de treinamento da Secretaria Municipal de Educação, com duração de três horas e meia.

\section{Conteúdo programático do treinamento:}

1. O que é conhecer

2. Breve histórico do Projeto Bertioga Município Saudável

3. Objetivos do levantamento do tecido social

4. Quem deve ser entrevistado

5. Estudo dos instrumentos da entrevista

6. Realização da abordagem e da entrevista

7. Formação das equipes de trabalho e definição de suas áreas de atuação.

Ao final do treinamento, foram definidas as duplas de trabalho com suas respectivas áreas de atuação. Ficou acertado que participariam somente as agentes de saúde que não pertenciam à Comissão Intersetorial. No inicio de cada dia de trabalho, seriam repassadas instruções gerais e, no final do período, seria feita uma avaliação do dia, quando se exporiam dificuldades e idéias para superá-las.

A pesquisa foi realizada durante seis dias do mês de abril e envolveu, basicamente, cinco duplas de pesquisadores, compostas de um pesquisador da USP e uma agente comunitária de saúde. Foram entrevistados 91 homens e 49 mulheres. 
Os bairros e localidades abrangidos pela pesquisa foram os seguintes: Vicente de Carvalho II, Sítio São João, Jardim Lido, Caiubura, Guarabira, Albatroz I, Albatroz II, Jardim Albatroz II, Jardim Paulista, Jardim Itapanhaú, Vila Tamoios, Jardim Albatroz, Vila Tupi, Vista Linda, Maitinga, Centerville, Vila Agaó, Jardim Rio da Praia, Uritinga, Mangue Seco, Jardim Rio da Granja, Rio Raso, Jardim Ana Paula, Jardim das Canções, Jardim Vista Alegre, Jardim Vista Linda, Jardim Rafael, Chácara Vista Linda, Indaiá, Jardim do Sol, Praia do Indaiá, Jardim Caiçara, Jardim Indaiá, Vista Alegre, Boracéia, Vila Tibúrcia, Guaratuba, Costa do Sol, Parque Jabaquara, Vila Clementina, Jardim São Lourenço, Condomínio Costa do Sol, Riviera São Lourenço, Jardim São Lourenço, Mogiano e Morada da Praia, abrangendo praticamente todo o município.

Os resultados da Pesquisa Exploratória foram sistematizados e constituíram-se na formação inicial de um banco de dados. A apresentação desses resultados encontra-se no Capítulo 7.

No início de junho, houve uma reunião da equipe da Faculdade de Saúde Pública com a Comissão Intersetorial, na qual se apresentaram os resultados da Pesquisa Exploratória e se iniciou a discussão da realização das Oficinas Regionais de Sensibilização, como próximo passo para a divulgação e sensibilização dos moradores de Bertioga.

\section{Sensibilização nas regiões}

As Oficinas Regionais de Sensibilização tiveram, como objetivo geral, a sensibilização de diferentes segmentos de atores sociais das diversas regiōes para participar do Projeto Bertioga Município Saudável.

Os objetivos específicos das oficinas realizadas foram: 
Riviera e São Lourenço (Área IV), EMEIF Indaiá (Área III) e EMEIF Boracéia (Área V). Nessas oficinas houve a participação de 141 participantes.

No final de cada oficina, solicitou-se o apoio de voluntários que pudessem exercer o papel de facilitadores, isto é, teriam a responsabilidade de articular os outros participantes para as oficinas do futuro, que se constituiriam no próximo passo do trabalho.

Durante esse período, houve a apresentação do projeto temático à comunidade de Bertioga, quando alguns pesquisadores de várias unidades da USP apresentaram propostas de pesquisas que pretendiam desenvolver em Bertioga, visando à melhoria da qualidade de vida em três eixos temáticos: Saúde e Saneamento; Meio Ambiente; Desenvolvimento Social e Econômico.

Ainda como estratégia de mobilização e sensibilização de segmentos considerados estratégicos no trabalho, foram realizadas oficinas de sensibilização de menor duração, cerca de duas horas, com 23 funcionários da prefeitura de Bertioga e as mais de 100 professoras da rede municipal.

Iniciou-se, também, um trabalho especifico de sensibilização com os índios da Aldeia Guarani do Rio Silveiras, por meio de uma oficina no dia 5 de setembro.

Os "facilitadores" foram convidados a participarem de duas reuniões, nas quais se discutiu, principalmente, a melhor estratégia de divulgação das Oficinas do Futuro, melhores locais para sua realização e melhores horários. Definiu-se que as escolas utilizadas nas Oficinas Regionais seriam adotadas para a realização das Oficinas do Futuro, e que seriam realizadas sete oficinas em diferentes horários para que dessem origem à formação de sete grupos locais. 
Como se tratava de um ano eleitoral em que haveria realização de eleições para prefeito e vereadores, a equipe da Faculdade de Saúde Pública considerou fundamental que todos os candidatos à prefeitura tomassem conhecimento da proposta do Projeto Bertioga Municipio Saudável, de suas perspectivas a médio prazo e que se firmassem compromissos mútuos de sua continuidade, independente das mudanças politicas que viessem a ocorrer. No dia 14 de setembro, realizou-se essa reunião, com a participação de 47 pessoas de diversos partidos. Estavam presentes participantes filiados aos seguintes partidos: PSB, PRP, PPB, PV, PSDB, PL, PT e PPS. Participaram também os candidatos a prefeito pelo $\mathrm{PT}, \mathrm{o}$ ex-prefeito e candidato pelo $\mathrm{PSB}, \mathrm{o}$ vice-prefeito candidato à reeleição e o candidato pelo $\mathrm{PL}$, que viria a ser o futuro prefeito da cidade.

Nessa ocasião, todos os candidatos se comprometeram a assumir a continuidade do projeto caso vencessem as eleições. Essa manifestação garantiu uma certa tranqüilidade quanto à continuidade e à sustentabilidade futura do projeto em Bertioga.

No início de outubro, sabendo da vitória do candidato de oposição, pertencente ao $\mathrm{PL}$, a equipe procurou agilizar os contatos para garantir sua participação no seminário municipal, que seria realizado após as Oficinas do Futuro e para estabelecer um novo plano de trabalho conjunto com a nova administração .

O próximo passo desta dissertação foram as Oficinas do Futuro, que serão descritas a seguir.

\section{Planejando o futuro}

As Oficinas do Futuro, como a própria nomenclatura sugere, tiveram como objetivo geral a construção de agendas de planejamento participativas 
para o municipio, baseadas no futuro que seus moradores desejam para Bertioga. Essas agendas a visavam estimular o diálogo entre os diversos segmentos da população e o poder público, em torno de ações para a melhoria da qualidade de vida e implantação do Projeto Bertioga Município Saudável.

Os objetivos especificos das oficinas realizadas em relação aos participantes consistiam em:

- Contribuir para despertar e/ou fortalecer os sentimentos de pertencimento e compromisso em relação a todo o meio ambiente natural e construído na região onde mora.

- Proporcionar a construção de técnicas de planejamento participativo e pesquisa participante que facilitem a compreensão ampla e crítica das condições sócio-ambientais locais.

- Contribuir para o levantamento e sistematização das demandas e propostas de parte da população de Bertioga, gerando subsídios para definição de políticas públicas saudáveis.

- Capacitar lideranças locais para o desenvolvimento de atividades que promovam a melhoria da qualidade ambiental e de vida na região.

- Formar grupos, representando os diversos segmentos da população constituindo, assim, os comitês regionais do Projeto Bertioga Município Saudável.

- Estabelecer redes de apoio ao Projeto Bertioga Município Saudável, interligadas entre si em todas as regiões.

Estrategicamente, as Oficinas do Futuro visavam a iniciar o diálogo entre os novos mandatários do poder municipal com os "grupos" que 
deveriam ser constituídos durante as oficinas. Além disso, havia uma expectativa de um maior "enraizamento" do Projeto Bertioga Município Saudável nas diferentes regiões de Bertioga.

No final de setembro, houve um treinamento para as Oficinas do Futuro, nas quais haveria a participação de dois coordenadores, sendo um da USP e um da prefeitura, dois relatores - um da USP e outro da prefeitura - e um observador. Os coordenadores tiveram o papel de conduzir todo o processo das oficinas, visando a estimular a participação de todos e à obtenção dos produtos de cada oficina. Os relatores tinham que registrar tudo que fosse falado durante as oficinas e os observadores tinham que registrar, especialmente, as reações e interações dos/entre participantes. Todas as oficinas foram fotografadas e gravadas.

As Oficinas do Futuro compuseram-se de quatro encontros, com duração média de 3 horas cada, com intervalo de uma semana entre cada reunião.

As Oficinas do Futuro constituíram-se em um espaço para se debater sonhos, problemas e ações conjuntas. As pessoas apontavam os problemas que as afligiam em cada bairro e seus sonhos com relação ao futuro de Bertioga. Posteriormente, o "grupo", com base em consenso, trabalhou teoricamente propostas para os problemas apontados, envolvendo a sociedade civil e o poder público.

As oficinas foram realizadas durante 16 dias, totalizando 84 horas, e houve um total de participação de 193 pessoas durante todo o processo. Foram realizadas nas cinco escolas utilizadas nas oficinas regionais, acrescidas da EMEIF de Jardim Paulista, sendo que em uma delas se dispunha de duas opções de horários. 
Os bairros e localidades com representação nas reuniōes foram os seguintes: Vicente de Carvalho II, São João, Jardim Lido, Albatroz I, Jardim Albatroz II, Jardim Albatroz I, Jardim Paulista, Vila Itapanhaú, Vila Tamoios, Jardim Albatroz, Maitinga, Centro, Centerville, Vila Agao, Jardim Rio da Praia, SESC, Mangue Seco, Parque Estoril, Jardim Rio da Granja, Maitinga, Jardim Rio Raso, Jardim Vista Linda, Indaiá, Vila Caiçara, Jardim Indaiá, Boracéia, Guaratuba, Riviera São Lourenço e Jardim Boa Esperança. Também foram realizadas oficinas do futuro na Aldeia Guarani do Rio Silveiras.

O principal resultado dessas oficinas foi a elaboração de sete agendas de prioridades locais e sugestões de ações para a solução de alguns problemas. Constituíram-se sete "grupos" que se autodenominaram "Grupo da Vila" , "Grupo Riviera Saudável", "Grupo Jardim Paulista", "Grupo Novas Idéias, Antigos Problemas", "Grupo Guara-Bora Bora-Guara”, "Grupo do Futuro" e "Grupo Indaián Houve algumas reuniōes preparatórias com os "grupos" constituídos para a preparação dessas agendas, que foram apresentadas no I Seminário Municipal do Projeto Bertioga Município Saudável realizado no início de dezembro de 2000.

Nem todos os objetivos das Oficinas do Futuro foram atingidos.

\section{Reunindo as Agendas para o Futuro}

O objetivo geral do I Seminário Municipal do Projeto Bertioga Municipio Saudável foi o de apresentar as agendas de prioridades locais construidas pelos diversos grupos de Bertioga, durante as Oficinas do Futuro. 
Alguns objetivos específicos do seminário:

- Discutir como implementar as agendas no município de Bertioga.

- Trocar experiências com os outros grupos e realizar o intercâmbio das suas agendas.

- Contribuir para o levantamento e sistematização das demandas e propostas de parte da população de Bertioga, gerando subsídios para definição de políticas públicas saudáveis.

- Iniciar o processo de discussão para a formação da futura Comissão Intersetorial e Interinstitucional do Projeto Bertioga Município Saudável.

Durante o seminário, os grupos apresentaram suas agendas por meio de painéis, transparências, folhetos, banners, música e falas. Também decidiu-se que a atual Comissão Intersetorial Interinstitucional provisória do Projeto Bertioga Município Saudável permaneceria até o início de 2001, quando seria constituída uma Comissão Intersetorial "permanente".

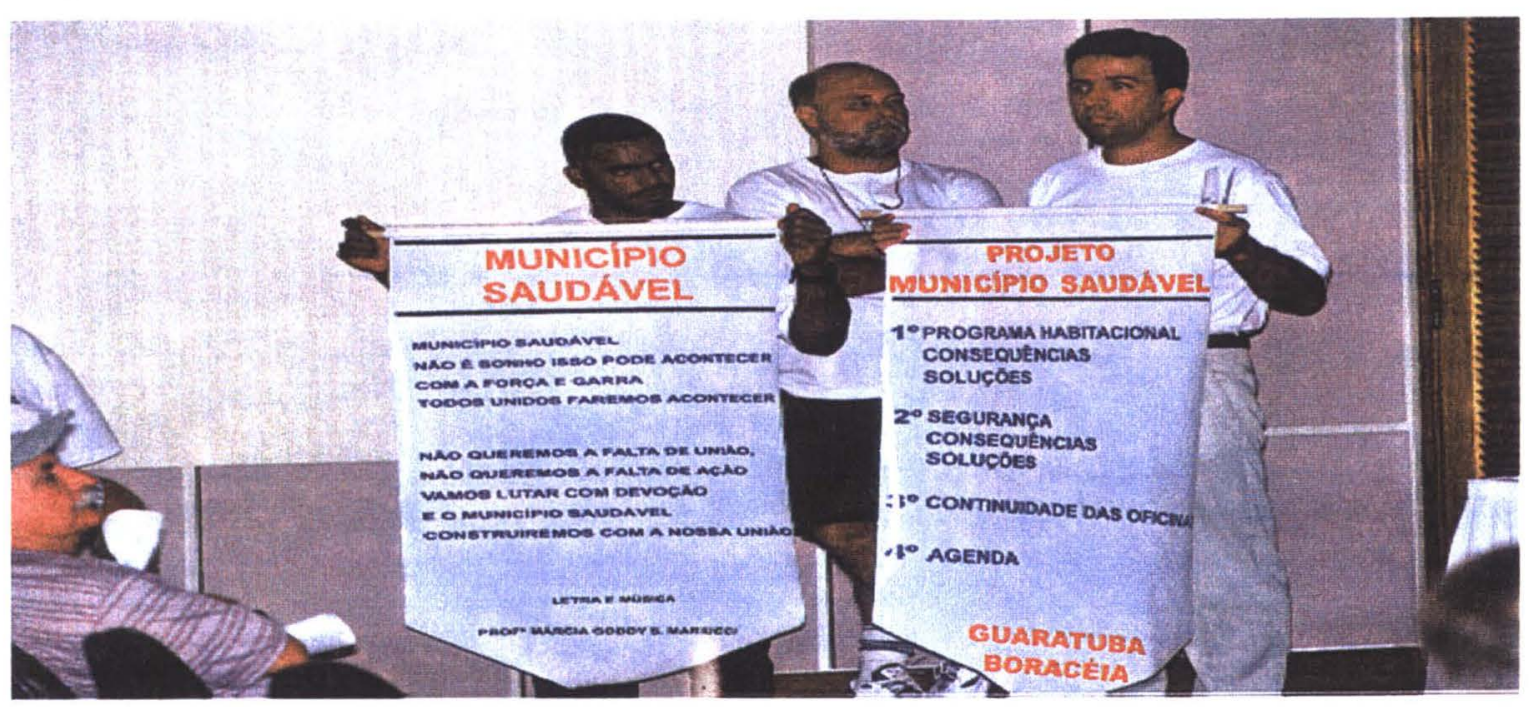

\section{FOTO 6: I SEMINÁRIO MUNICIPAL NO SESC BERTIOGA}

No final de 2000 , concluiu-se a elaboração de um projeto de avaliação que foi encaminhado para a Fapesp, que foi preparado durante todo $o$ ano $e$ 


\title{
Capítulo 7
}

\author{
ATORES SOCIAIS E SUAS \\ PERCEPÇÕES SOBRE A \\ REALIDADE DE BERTIOGA
}


...então esperança que daqui pra

frente a gente possa entender que depende de nós, que depende da gente estar participando... pra mudar esse quadro..." (fala de uma moradora da

Vila Agaó, durante uma oficina do futuro).

\section{A Participação da Sociedade Civil na Criação do Projeto (Iniciativa) Bertioga Municipio Saudável}

Durante o ano de 2000, diversos atores sociais participaram das atividades desenvolvidas pela Faculdade de Saúde Pública. Alguns participantes tiveram uma participação mais destacada, outros simplesmente estiveram presentes.

O caráter das atividades também variou, desde reuniões de repasse de informações, de planejamento de atividades e estratégias, de avaliação e tomada de decisões, até treinamentos, entrevistas, oficinas e seminários.

Diversos segmentos e organizaçōes da sociedade civil de Bertioga estiveram presentes e, da mesma forma, participaram das atividades somente como indivíduos.

No Quadro 1 (anexo 17), estão relacionados os nomes dos participantes, das diversas atividades do Projeto Bertioga Município Saudável desenvolvidas em Bertioga, suas ocupaçōes, seus bairros e região de moradia, segundo classificação baseada na Pesquisa Exploratória e a listagem das atividades em que participou.

As atividades representadas no Quadro 1 (anexo 17) são da $1^{\circ}$ Oficina de Sensibilização (OS1), da Pesquisa Exploratória (PE), das Oficinas Regionais de Sensibilização (OR), das Oficinas do Futuro (OF) e do I 
Tabela 2 - Total de participantes em cada atividade e percentual de retorno em atividades posteriores do Projeto Bertioga Município

Saudável.

\begin{tabular}{|c|c|c|c|c|c|c|c|c|c|}
\hline Atividades & $\begin{array}{l}\text { Total de } \\
\text { presentes } \\
\text { na PE e } \\
\text { nas OR } \\
\text { PE inter } \\
\text { OR }\end{array}$ & $\begin{array}{l}\text { Total de } \\
\text { presentes } \\
\text { na PE e } \\
\text { nas OF } \\
\text { PE inter } \\
\text { OF }\end{array}$ & $\begin{array}{l}\text { Total de } \\
\text { presentes } \\
\text { nas OR e } \\
\text { nas OF } \\
\text { OR inter } \\
\text { OF }\end{array}$ & $\begin{array}{l}\text { Total de } \\
\text { presentes } \\
\text { na PE, } \\
\text { nas OR e } \\
\text { nas OF } \\
\text { PE inter } \\
\text { OR inter } \\
\text { OF }\end{array}$ & $\begin{array}{l}\text { \% de } \\
\text { presentes } \\
\text { em } \\
\text { relação } \\
\text { ao total } \\
\text { da } \\
\text { atividade } \\
\text { anterior } \\
\end{array}$ & \begin{tabular}{|l|}
$\%$ de \\
presentes \\
em \\
relação \\
ao total \\
das duas \\
atividades \\
anteriores
\end{tabular} & $\begin{array}{l}\% \text { do } \\
\text { Total } \\
\text { com } \\
\text { repetição }\end{array}$ & $\begin{array}{c}\text { Total de } \\
\text { participantes } \\
\text { com } \\
\text { repetição }\end{array}$ & \begin{tabular}{|c} 
Total de \\
participantes \\
sem \\
repetição
\end{tabular} \\
\hline $\begin{array}{l}\text { Oficina } \\
\text { Sensibilizaçăo } \\
1 \\
\end{array}$ & & & & & & & 5,76 & 33 & 33 \\
\hline $\begin{array}{l}\text { Pesquisa } \\
\text { Exploratória }\end{array}$ & 37 & & & & 0 & & 24,30 & 140 & 140 \\
\hline $\begin{array}{l}\text { Oficinas } \\
\text { regionais }\end{array}$ & & & & 12 & 26,42 & & 24,47 & 141 & 111 \\
\hline $\begin{array}{l}\text { Oficinas do } \\
\text { futuro }\end{array}$ & & & 44 & & 31,20 & 4,27 & 33,50 & 191 & 146 \\
\hline $\begin{array}{l}\text { Seminário } \\
\text { municipal }\end{array}$ & & & & & & & $11,97^{\star}$ & $69^{*}$ & $33^{\star}$ \\
\hline $\begin{array}{l}\text { TOTAL } \\
\text { GERAL }\end{array}$ & & 14 & & & & & 100 & 574 & 463 \\
\hline
\end{tabular}

* Estes foram retirados do livro de presença do evento, mas muitos participantes não assinaram. A época era difícil e a contagem e registro falharam.

A tabela 2 indica que houve um crescimento gradual na participação durante 0 ano de 2000 , sendo que houve apenas uma queda durante o Seminário Municipal. Cerca de 111 participantes (cerca de $25 \%$ do total) estiveram em mais do que duas atividades realizadas, demonstrando uma certa continuidade. Da mesma forma, 37 entrevistados da Pesquisa Exploratória voltaram a participar das Oficinas Regionais, 44 participantes das Oficinas Regionais retornaram para as Oficinas do Futuro e 14 participantes da Pesquisa Exploratória estiveram presentes nas Oficinas do Futuro. Houve um retorno de $26,42 \%$ dos entrevistados na Pesquisa Exploratória, que voltaram a participar das Oficinas Regionais, e de $31,20 \%$ dos participantes das Oficinas Regionais, que voltaram a comparecer às Oficinas do Futuro. 
Um fator que deve ter influido negativamente na participação das pessoas foi o fato das Oficinas Regionais ocorrerem dois meses antes das eleições para prefeito e de as Oficinas do Futuro acontecerem logo após o resultado das eleições, quando já se sabia que não haveria continuidade na administração municipal. Outro aspecto a ser considerado foi o das estratégias de divulgação para cada atividade. Na Pesquisa Exploratória a divulgação foi realizada por meio de folhetos (Anexo 18) e da Comissão intersetorial. A divulgação das Oficinas Regionais deu-se por convites (Anexo 19), imprensa escrita e pela Comissão intersetorial. A divulgação das Oficinas do Futuro foi realizada pelos facilitadores, por algumas professoras, pela Comissão intersetorial e por meio de convites (Anexo 20) e imprensa escrita. O Seminário Municipal foi divulgado por convites (Anexo 12) e da imprensa escrita. Alguns convites impressos foram criticados durante as oficinas, por terem uma linguagem pouco direta e objetiva para a maioria da população. Muitos participantes também alegaram que tinham tomado conhecimento somente no dia da oficina, considerando que a divulgação havia sido fraca.

Quanto à classificação das ocupações presentes durante as atividades do projeto, o Gráfico 1 mostra que os estudantes estiveram presentes em maior número, seguidos dos funcionários públicos, comerciantes, donas-de-casa entre outras. Cabe destacar a presença de muitos aposentados, professoras e participantes ligados à construção civil. Entretanto, ao se consultar o Quadro 1 (anexo 17), verifica-se que os estudantes participaram especialmente nas Oficinas do Futuro e Oficinas Regionais, não tendo destaque durante a Pesquisa Exploratória. 


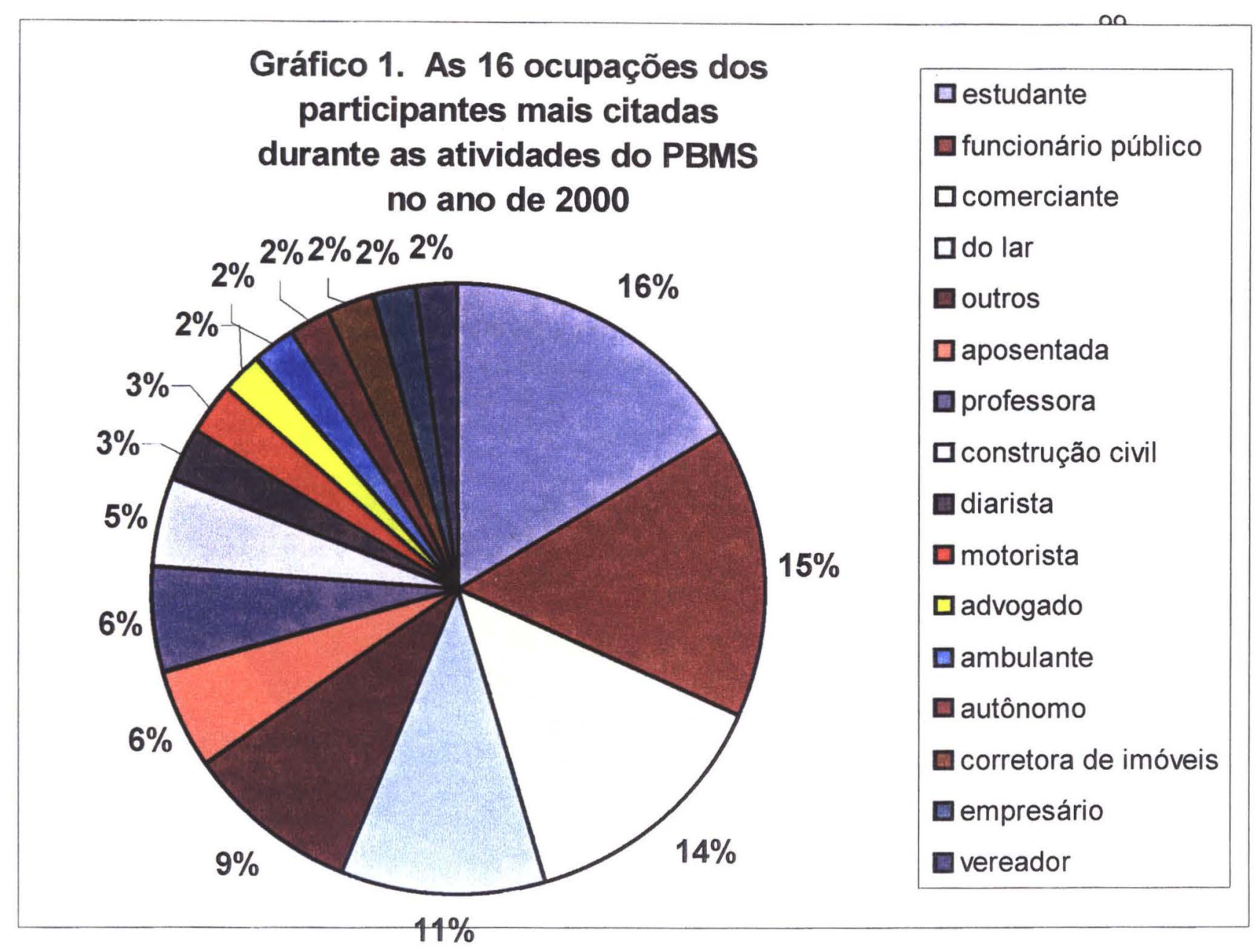

Conforme dados retirados de suas fichas cadastrais, esses participantes estão relacionados seja como dirigentes ou como associados a 87 grupos, associações, organizações ou instituições. Dessas entidades, 37 tem sua localização na área I (A), 12 na área II (B), 18 na área III (C), 14 na área IV $(D)$ e 11 na área $V(E)$.

O Gráfico 2, a seguir, mostra as categorias de entidades mencionadas durante a Pesquisa Exploratória. Durante o levantamento, os entrevistados foram indagados acerca de sua participação em algum grupo, entidade, organização ou instituição. 
Gráfico 2 - Citações de grupos,entidades, organizações e instituições de Bertioga nas quais os entrevistados

- no levantamento de lideranças - participam. As 14 mais mencionadas. - Bertioga - 04/2000

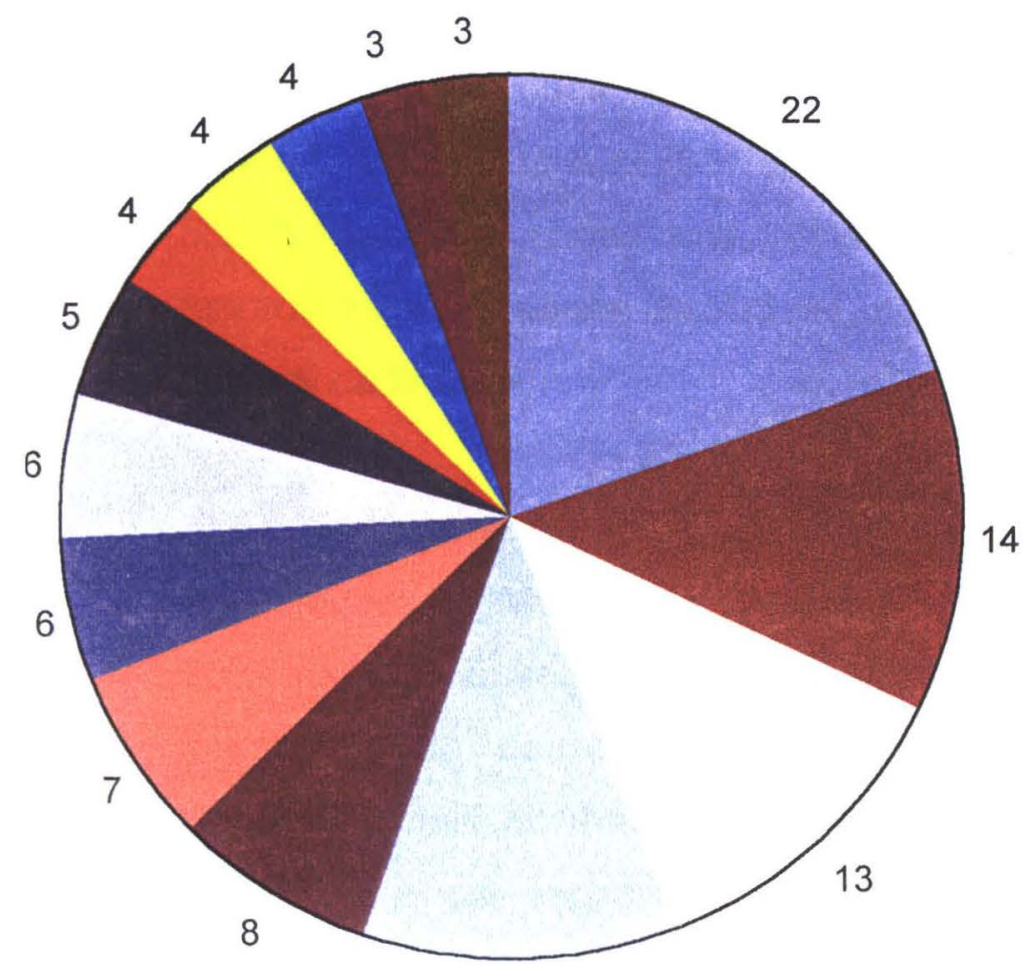

13 $\square$ Sociedades de Amigos de Bairros (22)

Associações e sindicatos classistas e de segmentos da sociedade (14)

$\square$ Conselhos (13)

$\square$ Entidades religiosas (13)

Partidos politicos (8)

$\square$ Escolas e creches (7)

口Associações de Moradores (6)

$\square$ Entidade esportiva (6)

Centros comunitários (5)

$\square$ Entidades ligadas ao turismo (4)

$\square$ Entidades, centros ou organizações culturais, ambientais (4)

Instituições filantrópicas (4)

Meios de comunicação (3)

Associações ligadas à escolas (3) 
A compilação das respostas mostrou que as Sociedades Amigos de Bairros compõem a maioria das entidades citadas, tendo 22 citações, 0 equivalente a $19,64 \%$ de um total de 112 citaçōes. Em seguida, as associações / sindicatos classistas e de segmentos da sociedade obtiveram 14 citações somando $12,5 \%$ do total. Os conselhos e as entidades religiosas tiveram 13 citações cada uma, correspondente a $11,60 \%$ do total cada uma, seguidas dos partidos políticos com oito citações, o que equivale a $7,14 \%$ do total. As escolas e as creches tiveram sete citações, o que corresponde à $6,25 \%$ do total cada uma, vindo, na seqüência, as associações de moradores e entidades esportivas, com seis citações, equivalente a $5,35 \%$ do total cada uma.

Somando-se as Sociedades de Amigos de Bairros com as Associações de Moradores, tem-se 28 citações de entidades, equivalente a $25 \%$ do total. Essas entidades, em geral, por estarem mais próximas dos moradores do bairros, têm uma tendência de defender interesses e atividades mais no âmbito local. Somando-se as associações e sindicatos classistas e de segmentos da sociedade, os conselhos, as entidades religiosas e os partidos políticos, tem-se $31,24 \%$ do total. Essas outras entidades, por tratarem muitas vezes de questões relacionadas ao município todo, defendem interesses mais amplos que os interesses locais. Portanto, há um aparente equilibrio entre entidades de atuação local e entidades de atuação municipal.

Os partidos políticos são bastante citados, revelando uma participação política relativamente alta dos entrevistados.

$\mathrm{Na}$ Tabela 3 é possivel visualizar as lutas e atividades desenvolvidas pelos grupos, entidades, organizações ou instituições, com base na sistematização dos cadastros dos entrevistados da Pesquisa Exploratória e participantes das Oficinas Regionais. Essas lutas e atividades estão separadas por área classificada segundo a Pesquisa Exploratória. 
Tabela 3- Lutas das entidades de Bertioga associadas às áreas.

\begin{tabular}{|l|c|c|c|c|c|c|}
\hline \multicolumn{1}{|c|}{ CATECORIA } & $\begin{array}{c}\text { AREA } \\
\text { A }\end{array}$ & $\begin{array}{c}\text { AREA } \\
\text { B }\end{array}$ & $\begin{array}{c}\text { AREA } \\
\text { C }\end{array}$ & $\begin{array}{c}\text { AREA } \\
\text { D }\end{array}$ & $\begin{array}{c}\text { AREA } \\
\text { E }\end{array}$ & TOTAL \\
\hline $\begin{array}{l}\text { Aprimoramento profissional/ } \\
\text { Condiçóes de trabalho }\end{array}$ & 3 & & & & 1 & 4 \\
\hline $\begin{array}{l}\text { Assisténcia sócio-económica e/ou } \\
\text { promoçáo social }\end{array}$ & 2 & 1 & 2 & 3 & 2 & 10 \\
\hline Atividades recreativas e culturais & 4 & & 3 & 1 & & 8 \\
\hline Cidadania & 3 & & & 1 & & 4 \\
\hline Comércio & 2 & 1 & & & & 3 \\
\hline Construção & 1 & & & & & 1 \\
\hline Cooperativa & & & & & 1 & 1 \\
\hline Correio & & & & & 2 & 1 \\
\hline Direitos indigenas & & & & & 1 & 1 \\
\hline Educaçăo & 4 & 1 & 3 & 2 & 2 & 12 \\
\hline Esporte e/ou lazer & 1 & 1 & 2 & & & 2 \\
\hline Fiscalizaçăo/ Denúncia & 2 & & & & & 2 \\
\hline Habitação & 2 & & 1 & & & 3 \\
\hline Justiça & 1 & & & & & 0 \\
\hline Limpeza pública & & & & & 2 & 2 \\
\hline Melhorias urbanas/ Regularização & 4 & & 3 & 2 & 1 & 10 \\
\hline Partido Politico & 2 & & 1 & & & 3 \\
\hline Proteção do meio-ambiente & 2 & & 3 & 2 & 1 & 8 \\
\hline Qualidade de vida & 1 & 1 & 1 & & & 3 \\
\hline $\begin{array}{l}\text { Recuperação e/ou combate às } \\
\text { drogas }\end{array}$ & 1 & 2 & & & & 3 \\
\hline Religiosas & 4 & 1 & 2 & 1 & 1 & 11 \\
\hline Resgate Histórico e Cultural & 2 & & & & & 2 \\
\hline Saneamento básico & 4 & 3 & & 2 & & 9 \\
\hline Saúde & 3 & 2 & 1 & 1 & 2 & 9 \\
\hline Segurança/ Policiamento & & & & 1 & 1 & 2 \\
\hline Turismo ou Ecoturismo & 2 & 2 & 1 & & 1 & 6 \\
\hline Outros & 12 & 6 & 6 & 3 & 5 & 32 \\
\hline TOTAL & 62 & 21 & 29 & 19 & 23 & 154 \\
\hline
\end{tabular}

$\mathrm{Na}$ área $\mathrm{A}$, destacam-se as lutas e atividades relacionadas à recreação, cultura, educação, melhorias urbanas/ regularização fundiária, religião e saneamento básico. $\mathrm{Na}$ área $\mathrm{B}$, ressaltam as lutas relacionadas ao saneamento básico, saúde, turismo e recuperação e/ou combate às drogas. $\mathrm{Na}$ área $\mathrm{C}$, sobressaem as lutas relacionadas à educação, recreação, cultura, melhorias urbanas/regularização fundiária e proteção ao meio ambiente. $\mathrm{Na}$ área $\mathrm{D}$, têm destaque as lutas relacionadas à assistência sócio-econômica e/ou promoção social, educação, melhoria 
urbana/regularização fundiária, proteção ao meio ambiente e saneamento básico. $E$, finalmente, na área $E$, sobressaem as lutas relacionadas à assistência socioeconômica e/ou promoção social, educação, saúde, correio e limpeza pública.

As lutas que aparecem em quase todas as áreas são as relacionadas ao saneamento básico, às melhorias urbanas e regularização fundiária e educação. Ocorre uma diferença entre as áreas $A$ e $C$, cujas lutas destacam as atividades relacionadas à educação e cultura, e as áreas $D$ e $E$, nas quais se destacam atividades relacionadas à assistência socioeconômica e ou/promoção social. Há um destaque para as áreas $C$ e $D$, com enfoque na proteção ao meio ambiente, e na área $E$, que destaca as lutas pelo correio e limpeza pública.

Quanto à participação da Comissão Intersetorial (Cl), é possivel visualizar nas tabelas 4 e 5 a participação dos seus membros em atividades relacionadas ao projeto. As principais atividades foram a primeira Oficina de Sensibilização (OS1), as reuniōes da Comissão Intersetorial $(\mathrm{Cl}), \quad 0$ treinamento para a Pesquisa Exploratória (TPE), o treinamento para as Oficinas Regionais (TOR), a coordenação e relatoria das Oficinas Regionais (COR e ROR), as Oficinas Regionais (OR), a avaliação das Oficinas Regionais (AOR), o treinamento para as Oficinas do Futuro (TOF), a coordenação e relatoria das Oficinas do Futuro (COF e ROF), as Oficinas do Futuro (OF), a avaliação das Oficinas do Futuro (AOF) e o I Seminário Municipal do Projeto Bertioga Municipio Saudável ( SM).

Junto com os membros da Comissão Intersetorial outros participantes se incorporaram às atividades com maior ou menor envolvimento. Para classificar o grau de participação de cada membro da comissão ou participante não membro durante todo o ano de 2000 , adotou-se um critério de dar um peso para cada tipo de atividade. As atividades de treinamento, avaliação, coordenação e relatoria de oficinas receberam o peso 3. As 
reuniões da Comissão Intersetorial receberam peso 2 e as atividades já tabuladas como a primeira Oficina de Sensibilização, a Pesquisa Exploratória, as Oficinas Regionais, as Oficinas do Futuro e o I Seminário Municipal do Projeto Bertioga Município Saudável receberem peso 1. Dessa forma, obtém-se alguns índices de participação resultantes do peso multiplicado pela freqüência de participação em atividades. Nove participantes recebem um índice maior do que 15 , indicando um elevado nível de participação. Sete participantes recebem um índice entre 5 e 14, indicando um médio nível de participação. E 16 participantes ficam com índice entre 2 e 4 , indicando um baixo nível de participação.

Tabela 4 - Participação da Comissão intersetorial nas atividades do Projeto Bertioga Município Saudável no ano de 2000

\begin{tabular}{|c|c|c|c|c|}
\hline $\begin{array}{l}\text { Comissão Intersetorial } \\
\text { Interinstitucional } \\
\text { provisória } \mathbf{2 0 0 0}\end{array}$ & $\begin{array}{l}\text { Participação } \\
\text { em atividades } \\
\text { gerais da } \\
\text { Faculdade de } \\
\text { Saúde Pública }\end{array}$ & \begin{tabular}{|l|} 
Participação em \\
reuniōes da \\
Comissão \\
Intersetorial \\
\end{tabular} & \begin{tabular}{|l|} 
Participação em \\
treinamentos e \\
avaliações
\end{tabular} & $\begin{array}{l}\text { Participação na } \\
\text { coordenação e } \\
\text { relatoria de } \\
\text { oficinas }\end{array}$ \\
\hline $\begin{array}{l}\text { Ana Maria Siqueira } \\
\text { Antunes André }\end{array}$ & $\mathrm{Cl}$ & CI & & \\
\hline Aldo Ennos de Moraes & & & & \\
\hline Aluisio Bichir & & & & \\
\hline Aparecida Maria Brasil & & & TPE & \\
\hline Célia Regina Pereira & SM & CI & & \\
\hline Diney Lyra & & & & \\
\hline Eliana Avelino dos Santos & & CI & & \\
\hline Elisabete de Castro Alves & SM & cl & & \\
\hline $\begin{array}{l}\text { Lais Helena Prearo } \\
\text { Jacopucci }\end{array}$ & SM & $\mathrm{Cl}$ Cl Cl $\mathrm{Cl}$ & & \\
\hline $\begin{array}{l}\text { Lúcia Maria Vasconcelos } \\
\text { de Mello }\end{array}$ & & CI & TPE & \\
\hline $\begin{array}{l}\text { Maurício dos Santos } \\
\text { Souza }\end{array}$ & SM & $\mathrm{Cl}$ & & \\
\hline $\begin{array}{l}\text { Márcio José Alvim do } \\
\text { Nascimento }\end{array}$ & & $\mathrm{Cl} \mathrm{Cl} \mathrm{Cl}$ & & \\
\hline Miriam Costejan & & CI & TPE & \\
\hline Mylene Lyra Pedroso & & & & \\
\hline Paulo Roberto Maria Velzi & & & & \\
\hline $\begin{array}{l}\text { Participantes das } \\
\text { atividades relacionadas à } \\
\text { Comissão Intersetorial } \\
\text { Interinstitucional } \\
\text { provisória }\end{array}$ & & & & \\
\hline
\end{tabular}


Tabela 4 - Participação da Comissão intersetorial nas atividades do Projeto Bertioga Município Saudável no ano de 2000

\begin{tabular}{|c|c|c|c|c|}
\hline $\begin{array}{l}\text { Comissão Intersetorial } \\
\text { Interinstitucional } \\
\text { provisória } 2000\end{array}$ & \begin{tabular}{|l|} 
Participação \\
em atividades \\
gerais da \\
Faculdade de \\
Saúde Pública
\end{tabular} & $\begin{array}{l}\text { Participação em } \\
\text { reuniōes da } \\
\text { Comissão } \\
\text { Intersetorial }\end{array}$ & \begin{tabular}{|l|} 
Participação em \\
treinamentos e \\
avaliações
\end{tabular} & $\begin{array}{l}\text { Participação na } \\
\text { coordenação e } \\
\text { relatoria de } \\
\text { oficinas }\end{array}$ \\
\hline Bolivar Barbanti Junior & $\overline{P E}$ & CI & & \\
\hline $\begin{array}{l}\text { Elaine Maria de Souza } \\
\text { Paião }\end{array}$ & SM OR & & TOR & \\
\hline $\begin{array}{l}\text { Eliana Paulino C. } \\
\text { Fernandes }\end{array}$ & OS1 & $\mathrm{Cl} \mathrm{Cl} \mathrm{Cl}$ & AOR & \\
\hline Elise Clara Rai Neto & & CI & & \\
\hline $\begin{array}{l}\text { Elizangela da Silva } \\
\text { Bernardino Ferreira }\end{array}$ & & cो & TPE & \\
\hline $\begin{array}{l}\text { Fátima de Lourdes Ramos } \\
\text { da Silva Vieira }\end{array}$ & & CI & TPE & \\
\hline José Senna & & CI & & \\
\hline Luiz Carlos Rachid & & cl & & \\
\hline Maria Calul R. da Silva & & cl & & \\
\hline $\begin{array}{l}\text { Maria do Carmo Moraes } \\
\text { Leroy }\end{array}$ & SM OS1 OR & & & $\mathrm{COR} \mathrm{COR}$ \\
\hline $\begin{array}{l}\text { Maria José da S. } \\
\text { Fernandes }\end{array}$ & & CI & TPE & \\
\hline $\begin{array}{l}\text { Maria Lúcia Soares } \\
\text { Monteiro }\end{array}$ & & CI & AOF & ROF \\
\hline Maria Madalena E. Souza & & CI & TPE & \\
\hline Nacima M. Navajas & OS1 OR & $\mathrm{Cl} \mathrm{Cl} \mathrm{Cl} \mathrm{Cl}$ & & \\
\hline Rizelda Alves & & cो & TPE & \\
\hline Simone Cristina Barrol & OS1 & & TPE & \\
\hline
\end{tabular}


Na Tabela 6 podemos verificar a composição da Comissão intersetorial formada no início de 2001 e sua participação nas atividades desenvolvidas pela Faculdade de Saúde Pública durante o ano de 2000.

Tabela 6 - Participação da Comissão intersetorial formada em 2001 nas atividades do Projeto Bertioga Município Saudável no ano de 2000

\begin{tabular}{|c|c|c|c|c|c|c|}
\hline $\begin{array}{l}\text { Comissão } \\
\text { Intersetorial } \\
\text { formada em } 2001\end{array}$ & Atividade & Area & $\begin{array}{l}\text { Participação } \\
\text { em } \\
\text { atividades } \\
\text { gerais da } \\
\text { Faculdade } \\
\text { de Saúde } \\
\text { Pública }\end{array}$ & $\begin{array}{l}\text { Participação } \\
\text { em reuniões } \\
\text { da } \\
\text { Comissão } \\
\text { Intersetorial }\end{array}$ & $\begin{array}{l}\text { Participação } \\
\text { em } \\
\text { treinamentos } \\
\text { e avaliações }\end{array}$ & $\begin{array}{l}\text { Participação } \\
\text { na } \\
\text { coordenação } \\
\text { e relatoria de } \\
\text { oficinas }\end{array}$ \\
\hline Aluísio Bichir & $\begin{array}{l}\text { Diretor de } \\
\text { vigilância } \\
\text { sanitária }\end{array}$ & $\mathrm{A}$ & $\begin{array}{r}\mathrm{SM} \text { Cl } \\
\text { OS1 }\end{array}$ & $\begin{array}{llll} & \mathrm{Cl} & \mathrm{Cl} & \mathrm{Cl} \\
& \mathrm{Cl} & \mathrm{Cl}\end{array}$ & $\begin{array}{l}\text { AOF TOF } \\
\text { TOF TOF } \\
\text { TOF AOR }\end{array}$ & $\begin{array}{r}\text { COR COR } \\
\text { COR }\end{array}$ \\
\hline Cláudio Isola & Empresário & A & & & & \\
\hline Ditmar Schimidt & Artesão & $B$ & SM & & & \\
\hline Fisao Tanabe & Aposentado & C & $\mathrm{OBPE}$ & & & \\
\hline Luiz Chardulo & Advogado & D & OF & & & \\
\hline $\begin{array}{l}\text { Manoel Prieto } \\
\text { Alvarez }\end{array}$ & $\begin{array}{l}\text { Secretário } \\
\text { de Obras e } \\
\text { Meio } \\
\text { Ambiente }\end{array}$ & & SM & & & \\
\hline $\begin{array}{l}\text { Márcia Maria Rúbio } \\
\text { Marchi }\end{array}$ & Professora & $\mathrm{C}$ & $\begin{array}{|lr|}\text { SM } & \text { OF } \\
& \text { OR } \\
\end{array}$ & & & \\
\hline $\begin{array}{l}\text { Maria Julieta Farah } \\
\text { Lanças }\end{array}$ & $\begin{array}{l}\text { Secretaria } \\
\text { de } \\
\text { Educação }\end{array}$ & D & SM & & & \\
\hline $\begin{array}{l}\text { Maurício dos } \\
\text { Santos Souza }\end{array}$ & $\begin{array}{l}\text { Funcionário } \\
\text { público }\end{array}$ & A & $\begin{array}{cc}\text { SM } & \mathrm{Cl} \\
\mathrm{OS1} & \mathrm{OR}\end{array}$ & $\mathrm{Cl} \mathrm{Cl} \mathrm{Cl}$ & & \\
\hline $\begin{array}{l}\text { Quirino Alves } \\
\text { Carneiro Filho }\end{array}$ & Comerciante & B & OF & & & \\
\hline $\begin{array}{l}\text { Wladimir E. R. S. } \\
\text { Grudzinslei }\end{array}$ & $\begin{array}{l}\text { Funcionário } \\
\text { público }\end{array}$ & B & OF & & & \\
\hline
\end{tabular}

Verifica-se que houve uma renovação bastante grande na composição da nova Comissão Intersetorial, provavelmente devido à mudança administrativa na prefeitura e às atividades realizadas pelo PBMS. Outro fator relevante é que seis novos integrantes participaram das Oficinas do Futuro e cinco participaram das Oficinas Regionais, indicando uma certa influência dessas atividades nessa composição. 


\section{Bertioga e seus atores: percepção do presente, suas raízes}

Para realizar o intento de trazer à luz e interpretar as percepções dos moradores acerca de Bertioga, tomamos por base, além do referencial teórico norteador desta dissertação, os materiais resultantes do processo de pesquisa empirica. A primeira fonte para análise foi a Pesquisa Exploratória, visando a determinar uma listagem tanto dos principais problemas quanto dos aspectos positivos de Bertioga na ótica de seus moradores.

Uma segunda fonte foi a leitura do material produzido pelos relatores, a transcrição das fitas gravadas durante as Oficinas Regionais e do Futuro e a definição de algumas categorias de análise, as quais permitiram aprofundar a leitura que seus moradores fazem de Bertioga.

Uma terceira fonte de material foram as entrevistas realizadas conforme um roteiro previamente estabelecido, a fim de verificar os efeitos das metodologias participativas no protagonismo dos participantes das atividades do PBMS. Embora essas percepçōes tenham um componente subjetivo importante, o componente objetivo também colaborou na formação desta percepção tanto que existiram recorrências seja em relação às percepções e convergências sobre os problemas. Quando o canal da subjetividade fica aberto, é possível obter outros dados que indicam novos caminhos. Neste sentido o que aconteceu, um exemplo foi a mudança ocorrida em relação à percepção de linhas de ação para resolver os problemas do município, que adquiriram uma nova conotação de prioridades, depois de expressos os sonhos para uma Bertioga saudável.

Algumas dessas percepções apreendidas durante as oficinas foram categorizadas em imagens compartilhadas, imagens monumentais (TASSARA \& RABINOVICH, 2001) e imagens cotidianas. As imagens compartilhadas referem-se às que são recorrentes nas diversas oficinas das diversas regiōes. As imagens monumentais referem-se aos monumentos 
como marcos institucionalizados. As imagens cotidianas são aquelas que, temporalmente, constituem-se em vivências de situações do dia-a-dia.

Após a tabulação de 134 questionários aplicados durante a Pesquisa Exploratória, na qual se solicitava que os respondentes citassem três problemas de seu bairro, foi possível visualizar o Gráfico 3, que mostra os 15 problemas mais citados do município de Bertioga. Os problemas foram agrupados por semelhança e "rankeados". Os gráficos 4, 5, 6, 7 e 8 correspondem aos quatro problemas mais citados por região de mapeamento.

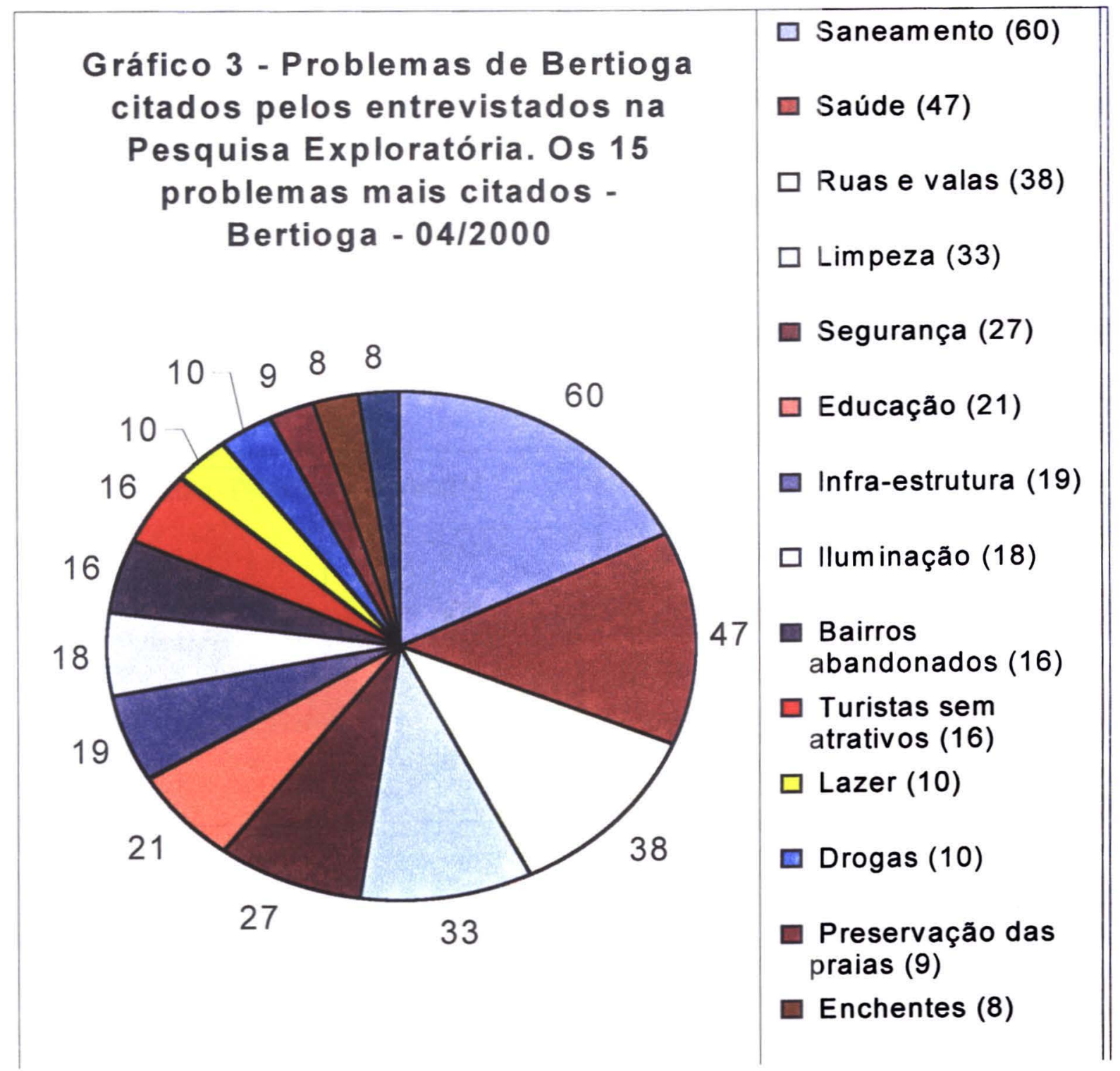



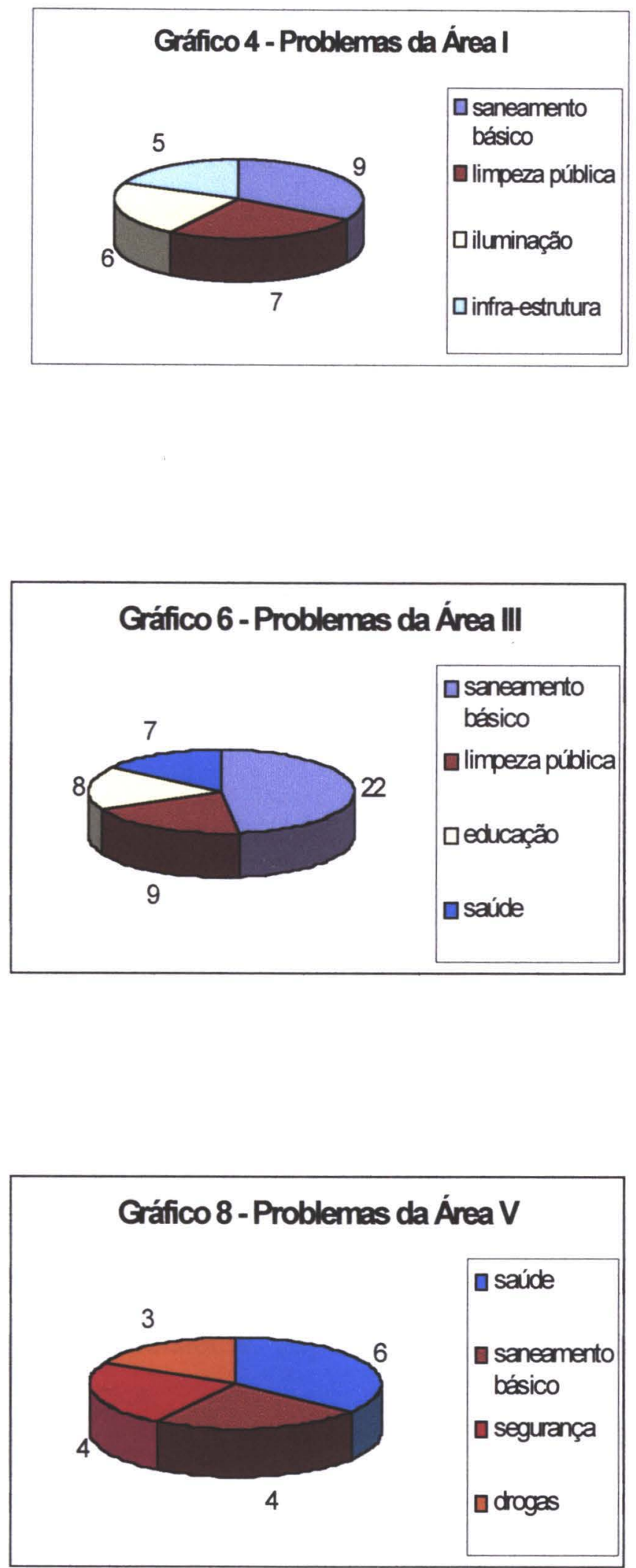
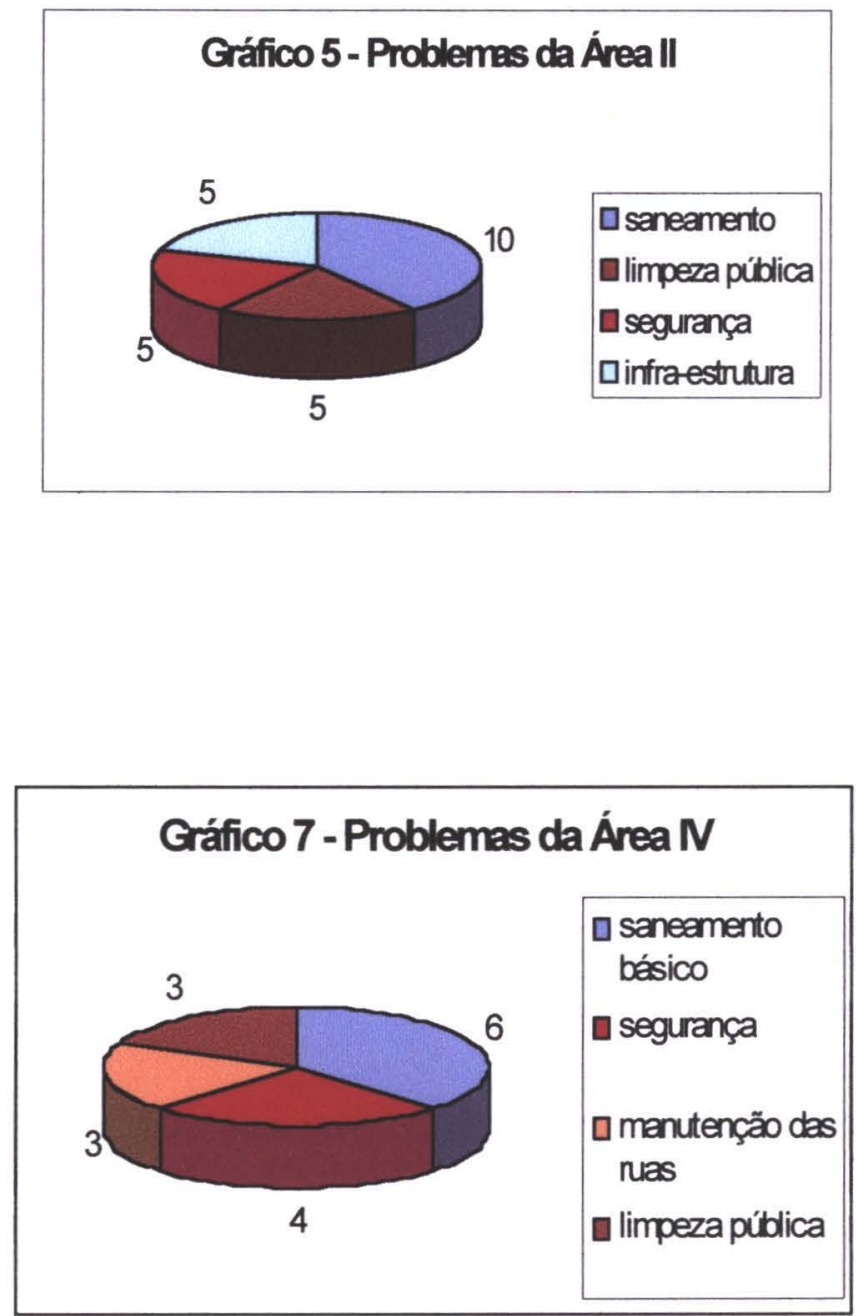


\section{A falta de saneamento básico}

Por meio do gráfico 3 , percebe-se que, para a maioria dos entrevistados, o maior problema de Bertioga é a falta de saneamento básico, com 60 citações ou $13,54 \%$ do total de 447 citações. Se a esse problema somarmos problemas correlatos como a manutenção das valas, falta de infra-estrutura e abandono dos bairros, esse porcentual atinge 133 citaçōes ou $29,89 \%$ do total.

O problema do saneamento básico também é citado na grande maioria das oficinas regionais de forma direta ou indireta. Essa imagem cotidiana está presente em todas as regiōes de Bertioga até mesmo quando se separam os problemas principais por região de acordo com os gráficos 4 , $5,6,7$ e 8 .

Em alguns momentos as falas representam a preocupação com conseqüências para a saúde da ausência de esgoto. $A$ inexistência desta infraestrutura, em áreas carentes, permite que os dejetos humanos contaminem o solo, pondo em risco a saúde deste segmento da população, já tão discriminado.

"...quem mora nas favelas, vive dentro dos esgotos, afeta muito a saúde (....) (Morador de Rio da Praia)

As falas expressaram ainda uma preocupação com a sustentabilidade do ecossistema, especialmente com a contaminação do mar com matéria orgânica.

(....) até nos bairros mais nobres o esgoto cai no mar" (Morador de Rio da Praia).

A relação do saneamento com o problema das valas e da habitação também foi referida por um dos participantes de Rio da Praia: 
"..rede de esgoto feita, com certeza não teria valas".

"...habitação tem a ver com saneamento".

Uma imagem de fatalidade, de ameaça à sobrevivência, foi relacionada ao problema do saneamento: Rio da Praia).

"Saneamento básico, se não sair rápido, todos em Bertioga morrerão!" (Morador de

\section{Causalidade dos problemas de saneamento}

O grupo de Rio da Praia estabelece as seguintes conexões ao discutir a falta de saneamento básico, ligando o problema a questões administrativas relacionadas ao governo local e questões de comportamento dos moradores, causa dependente de educação das pessoas :

(....) por que não tem falta de saneamento básico? Vocês falaram: porque não tem a limpeza das valas, falta da rede coletora e água (....) inadequada. Isso aqui a gente não viu, mas vamos ver o que aconteceu: por que não tem a limpeza das valas? Porque não tem programação, não tem fiscalização e falta de colaboração da comunidade e a falta de educação das pessoas e no caso, das pessoas que jogam lixo nas ruas. Porque tem falta de esclarecimento. Por que não tem programação? Porque não tem recursos. Porque tem um mau gerenciamento. Por que tem um mau gerenciamento? Porque tem má administração. Por que tem má administração.

\section{Percepção negativa do atendimento à saúde}

O atendimento à saúde, em seus diversos aspectos, é o segundo problema mais mencionado, com 47 citações ou $10,53 \%$ do total. O prontosocorro é uma imagem monumental, que remete a aspectos negativos, relacionados ao cotidiano de muitos moradores de Bertioga. A ausência de postos de saúde também é mencionada. 
Algumas pessoas - mais do que as que manifestaram agrado, segundo resultados da Pesquisa Exploratória - expressaram uma insegurança e um desagrado com o atendimento oferecido em situações de emergência. Referem ainda que o Pronto Socorro, além de não atender bem ainda é um local sujo, o que expressa uma sensação de desrespeito com as pessoas que o procuram.

"Pronto socorro é péssimo!" (Morador de Boracéia).

"Na Riviera falta posto de saúde" (Morador de Riviera).

"Não temos uma ambulância!" (Morador de Boracéia).

"Pronto socorro deixa a desejar- sujeira e mal atendimento" (Morador de Rio da Praia)

Se os problemas forem vistos sob o enfoque de cada região, a questão da saúde é um dos problemas mais citados de acordo com os gráficos 6 e 8 A região $V$, desprovida de serviços públicos, a mais despovoada, e a mais distante do "centro", apresenta a questão da saúde como o problema mais citado e o problema das drogas como uma peculiaridade. Na região III situada a meia distância entre a região $\mathrm{V}$ e a região em que se localiza o "centro" destacam-se os problemas da saúde e educação.

Outros em contraposição mencionam o bom atendimento no Pronto Socorro. $O$ atendimento na área da saúde é considerado um aspecto positivo por 10 entrevistados ou $2,67 \%$ do total segundo dados da Pesquisa Exploratória sistematizados no gráfico 9 . Indaiá).

"Sempre que necessito sou bem-atendida, temos remédios de graça" (Moradora de

O fato de parte dos entrevistados considerarem como problemas alguns aspectos positivos, apesar de contraditório, pode indicar que parcelas 
da população não usufruem de uma mesma qualidade de serviços públicos, não possuindo uma mesma percepção sobre os mesmos.

\title{
Relação entre problemas de saúde e outros problemas: a visão de causalidade múltipla do processo saúde/doença
}

Para os que residem mais longe, a centralização dos serviços de saúde (todos estão alocados no "centro"), não os deixa satisfeitos. Pedem mais postos de saúde, sugerindo a descentralização do serviço, como propõe o SUS na Constituição de 1988 e a lei 8080 que o regulamenta.

É interessante observar que o primeiro problema - falta de saneamento básico - bem como o terceiro - falta de manutenção das ruas e valas - e o quarto - falta de limpeza - têm relação direta com a saúde pública, reforçando a necessidade de uma visão intersetorial dos problemas e das soluções. Alguns participantes percebem essa relação causal direta:

\begin{abstract}
Desenhamos o mapa e seus problemas principalmente a saúde. Muitos cachorros, ratos, que trazem doenças - Riviera densamente urbanizada que no futuro pode dar problemas, de água, esgoto. Boracéia que é menos urbana, também tem problemas - não tem rede de água tratada...esgoto tratado no centro e na Riviera, água tratada tem do lado de cá da pista - do lado de lá muito pouco.

Nossas valas não têm tratamento, água parada cria bicho, ciclo de doenças. Água pluvial juntando com lençol freático. (Participante no Delphino).
\end{abstract}

Algumas causas dos problemas do setor mais especificamente da saúde foram discutidas no grupo de Riviera e resultaram na seguinte leitura procedida pela coordenadora da oficina que confirma a observação sobre a necessidade de melhoria da gestão do sistema local de saúde e a necessidade de descentralizar serviços e estender a cobertura para a maioria da população:

(....) por que saúde é um problema para esse grupo. Entäo nós vimos o seguinte: a falta de médico, a falta de médico é um problema por que? Porque existe má gestão do recurso, porque existe má administração, porque existe falta de cidadania! $E$ aí a falta de atendimento de emergência 
com qualidade (....) Por que? Existe falta de atendimento, existe um pronto socorro sujo, pessoal despreparado, existem equipamentos, e os equipamentos para montagem de um pronto socorro são caros. E esses equipamentos são caros porque o pronto socorro aqui teria que ser montado pra atendimento à população em geral, em todas as partes, áreas...Bertioga. E o pronto socorro é sujo e o pessoal é despreparado porque existe falta de formação (....) existe uma falta de vontade política. Se houvesse vontade política, saúde não seria problema! Por que que existe falta de vontade política? Primeiro, porque não dá lucro, atendimento, segundo vocês, assistência médica não dá lucro. Segundo que não dá retorno político. E aí vocês colocaram alguns exemplos. E ai outra causa da saúde ser problema em Bertioga pra esse grupo é a ausência de postos de atendimento nos bairros. E por que que existe essa ausência de postos de atendimento nos bairros. Porque falta recursos, recursos financeiros, recursos humanos e na questão administrativa também. (Fala da coordenadora da segunda Oficina do Futuro do Grupo de Riviera após plenária para discussão dos motivos da saúde serem um problema para o grupo).

Outra constatação é o fato dos serviços de saúde ficarem sobrecarregados durante a época da temporada dos turistas ou finais de semana prolongados quando há um aumento populacional e um não correspondente aumento na oferta de atendimento na área da saúde:

(....) saúde é um problema pra esse grupo também porque existe o crescimento de uma nova população, ou seja, em época de temporada ou fim de semana prolongado, os serviços públicos ficam superlotados e não dão conta (Fala da coordenadora da segunda Oficina do Futuro do Grupo de Riviera após plenária para discussão dos motivos da saúde serem um problema para o grupo).

\section{Clientelismo e salário $x$ direitos de cidadania como causa indireta} dos problemas de atendimento à saúde

O Grupo do Futuro, ao proceder à mesma discussão sobre as causas do mau atendimento, chegou a resultados que mostram que há falhas na estrutura organizacional interna dos serviços de saúde:

(....) vocês disseram também que mal atendimento ocorre por falta de médicos e falta de tudo, falta de comunicação, falta de reuniōes, falta de boa intenção, vocês falaram também que falta tudo porque falta organização, porque falta interesse da administração, por incompetência e falta de verbas, então essas são as causas que vocês estão levantando aqui, que o mal atendimento ele ocorre porque há um problema da estrutura operacional, porque os profissionais não são concursados, porque há 
um apadrinhamento, né, paramos aí, por que que esses profissionais não são concursados? Porque falta fiscalização (....) (fala da coordenadora da segunda Oficina do Futuro do Grupo do Futuro de Rio da Granja após plenária para discussão dos motivos do mau atendimento serem um problema para a saúde pública)

Esse mesmo grupo questiona a competência e a dedicação de alguns profissionais no setor da saúde quanto ao atendimento à população:

(....) falta de respeito com o ser humano, isso também está ligado ao fato do funcionário atender mal, não é, então também falta fiscalização e falta a falta de respeito ao ser humano é porque o profissional não tem amor a profissão e porque não tem chefe responsável. (fala da coordenadora da segunda Oficina do Futuro do Grupo do Futuro de Rio da Granja após plenária para discussão dos motivos do mau atendimento serem um problema para a saúde pública)

A questão salarial também é apontada como um fator do mau atendimento à população:

(....) Quando a gente perguntou qual era, porque que o mal atendimento era um problema de saúde pública, vocês responderam mais coisas. Porque faltam profissionais competentes, porque estrutura operacional é ineficaz, porque o funcionário atende mal, aí vocês falaram também que muitos profissionais estão no setor privado porque tem salários baixos e a exigência maior, altos e exigência maior (fala da coordenadora da segunda Oficina do Futuro do Grupo do Futuro de Rio da Granja após plenária para discussão dos motivos do mau atendimento serem um problema para a saúde pública)

As percepções das causas, algumas vezes, confundem-se com os próprios problemas. Nem todas as prioridades puderam ser aprofundadas nem grande parte das causas ou os nós críticos da cadeia causal (MATUS apud MIR, 1990), porém o trabalho permitiu visualizar a relação entre as diversas causas e alguns atores envolvidos nos problemas.

\section{Percepção da falta de segurança}

Outro problema relevante citado pelos entrevistados é a falta de segurança com 27 citações ou $6,05 \%$ do total. Em todas as oficinas regionais esta questão é levantada. O problema de falta de segurança 
destaca-se nas regiōes II, IV e V que são as mais carentes e mais desprovidas de serviços públicos.

"Em São Lourenço não tem segurança, entram por lá para Riviera" (Morador de Riviera).

"Segurança é muito importante e guarda municipal deveria executar um trabalho melhor na segurança junto com a polícia militar" (Morador de Indaiá)

Até as escolas na percepção dos participantes está sendo ameaçada e até invadida, o que parece preocupar aos que têm filhos em idade escolar.

"Está diminuindo a segurança. Precisa melhorar as escolas que já tem. A escola de Guaratuba foi roubada" (Morador de Boracéia).

\section{Relação da falta de segurança e alguns de seus fatores causais}

Para alguns moradores, o problema da falta de segurança está relacionada ao problema do aumento do consumo de drogas no município. Este fato indica a existência de uma visão do consumo de drogas relacionada a questão de segurança pública. Este problema teve 10 citações ou $2,24 \%$ do total.

"Falta segurança, (....) também tem muitos drogados, muito arrombamento" (Oficina do Futuro, em Boracéia),

"A cidade está crescendo e é preciso cuidar da questão da segurança. Questão de recolocar usuários de droga na sociedade" (Morador de Rio da Praia).

Um participante do grupo do Delphino questionou 0 fato de 0 problema das drogas ter pouca relevância em relação aos outros problemas:

"A questão das drogas por que ela está em baixa. Para mim o problema com a droga para crianças é muito grave" (Participante do grupo de Delphino)

Alguns estabelecem uma relação causal entre a falta de segurança com a migração e desta com o surgimento de favelas, sem demonstrar que 
percebem a causa primeira desta ocorrência, que tem sido a necessidade de importação de mão de obra para a construção civil e a condição de vida oferecida a esse segmento após o término da obra . Na seqüência esse assunto vai aparecer com mais detalhe.

"Fora os assaltos. Eu tenho medo de sair à noite. Essa é a dura realidade nossa. Aqui virou refúgio de bandidos. Em Guaratuba, várias favelas começando. Não existe programa habitacional“ (Morador de Boracéia).

\section{A limpeza pública como problema sentido}

O problema da falta de limpeza é mencionado em várias oficinas regionais e constitui-se, também, em uma imagem cotidiana na vida de muitos dos moradores de Bertioga.

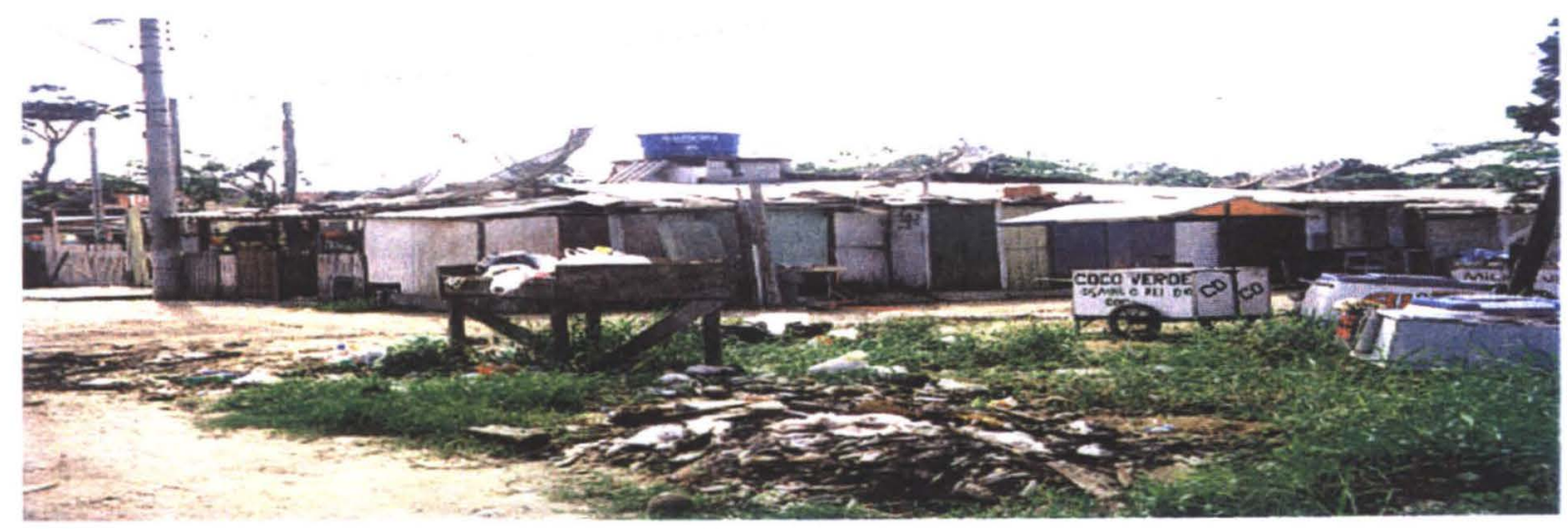

\section{FOTO7 : FALTA DELMPEA PÚBLICA EM VICENTE DE CARVALHO I}

A falta de limpeza pública como problema, destaca-se em quatro regiões de acordo com os gráficos 4, 5, 6 e 7. Referem à falta de limpeza como problema no centro da cidade e no canal, porque deprecia a cidade:

"O cheiro do canal e peixes mortos, um cheiro horrivel, no forte tem muito lixo na temporada" (Morador de Riviera).

Em outras áreas a preocupação volta-se para a questão do destino final do lixo, ou melhor dos comportamentos inadequados em relação a isto, 
que são reforçados pela falta de recipiente para receber o lixo especialmente nas praias, que para todos é um valor a ser preservado pelos moradores.

"...queria mudar a questão do lixo, jogado nas praias, no rio, as praias fossem mais limpas" (Participante no Delphino).

"centro (....) totalmente sujo, falta de higiene" (Morador de Rio da Praia).

Chamam atenção também de que o último bairro também carece de limpeza, reforçando o sentido pejorativo de ser um bairro ignorado e abandonado pelos poderes públicos.

"Aqui é Boracéia, é o fim, é o último bairro - um lixo!" (Morador de Boracéia).

Gráfico 9 - Aspectos positivos de Bertioga citados pelos entrevistados no levantamento de lideranças. Os 15 aspectos positivos mais citados - Bertioga - 04/2000

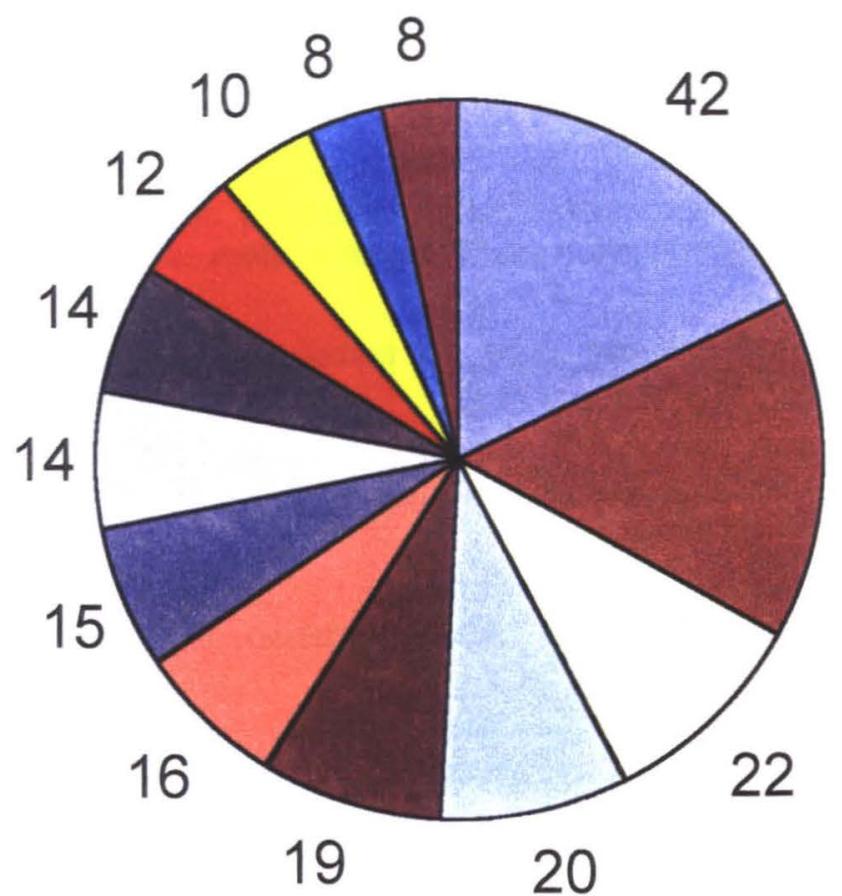

$\square$ As praias (42)

$\square$ Belezas naturais (36)

$\square$ Potencial turístico (22)

$\square$ Sossego (20)

๑ Segurança pública (19)

口 Mata Atlântica (16)

口 Patrimônio histórico

(15)

$\square$ Aspectos do povo (14)

- Nenhum (14)

a Qualidade de vida (12)

$\square$ Atendimento saúde (10)

口 Preservação ambiental (8)

- Atendimento educação (8) 


\section{Praias}

No gráfico 9, verifica-se que as praias se constituem no aspecto positivo mais mencionado pelos entrevistados com 42 citações ou $11,21 \%$ de um total de 339 citações. Se somarmos os porcentuais de todos os aspectos positivos relacionados aos recursos naturais de Bertioga, como praias, belezas naturais, Mata Atlântica, área de preservação ambiental, mar, clima, ar puro, pescaria, bacias hidrográficas, ecossistema do rio Itapanhaú, mangue, fauna, cachoeiras e canal de Bertioga, o porcentual atinge $38,47 \%$.

\section{Praias: um potencial de valorização que não pode ser perdido}

Durante as Oficinas Regionais, as praias de Bertioga são freqüentemente mencionadas e são uma das imagens compartilhadas de maior consenso entre os moradores, quanto a se constituírem em um dos aspectos positivos da cidade.

"Os aspectos positivos de Bertioga independem da ação do homem os melhores pontos de Bertioga. Considera que o que está na mão do homem é o que está mais complicado. O resto - praias, potencial turístico- a cidade já tem". (Morador de Rio da Praia).

“...Vários problemas, mas belezas naturais (....) Bertioga tem coisas boas, sol, praias, surfista,..mata, mas tem muita coisa para fazer" (Participante no Delphino). Boracéia).

“O que nós temos de bom, são as belezas naturais, as praias! (Morador de

"Tem praias, é bonita, tem potencial turístico" (morador de Boracéia)

\section{Sossego ou insegurança: um misto de preocupação e valor}

Apesar de questão da segurança pública ser citada como o quinto problema, o sossego e $\circ$ item mencionado anteriormente são, 
respectivamente, o quarto e o quinto aspectos positivos citados no Gráfico 9 (que será mostrado na seqüência), somando 39 citações ou $10,41 \%$ do total. O tema da segurança é um aspecto que envolve diferentes aspectos relacionados às diferenças territoriais e à percepção do que é se sentir seguro:

"No centro não tem perigo, mas perto de Indaiá, Maitinga é diferente" (Morador de Rio da Praia).

"Segurança de se sentir seguro, năo de quantidade de policiamento" (Morador de Rio da Praia).

"Depende do local onde as pessoas moram" (Morador de Rio da Praia).

\section{Recursos naturais: outro valor? 0 ecossistema precisa ser preservado?}

Além das praias, os outros recursos naturais são lembrados como imagens compartilhadas:

“Conscientização sobre o meio ambiente. Bertioga tem $80 \%$ da área sob preservação ambiental. Preservação. Mar, cachoeiras, praias". (Morador de Rio da Praia).

"...com preservação tem a mata atlântica. Tem a atividade de pesca, o recurso natural, fauna e flora. Infra-estrutura: Serra do Mar, o estuário dos rios" (Morador de Boracéia).

\section{A identidade com o local e o cultural}

Outros aspectos positivos interessantes a serem ressaltados são o patrimônio histórico e as características positivas do povo, que ocupam a oitava e nona posições, com 15 e 14 citações ou 4,01 e $3,74 \%$ respectivamente, do total de entrevistados. O Forte São João, localizado no centro da cidade, é uma referência histórica e constitui-se numa imagem 
monumental que transcende diversas gerações. Outra imagem monumental menos recordada é a usina hidroelétrica localizada em Itatinga.

“...colocamos o forte de São Joăo" (Morador de Boracéia).

"Raizes de Bertioga: presenvar espaço cultural, patrimônio, forte, usina hidroelétrica, esporte, área de lazer. Conservação. Preservar a história de Bertioga" (Morador de Rio da Praia).

Quanto ao aspecto de territorialidade, os participantes da Pesquisa Exploratória e das oficinas assinalaram o bairro onde moram. Durante as Oficinas Regionais, no entanto, nem todas as localidades de Bertioga são mencionadas.

A Riviera é mencionada praticamente em todas as oficinas seja de uma forma positiva, seja de uma maneira mais crítica, materializando uma imagem compartilhada que é sempre uma referência na comparação com a situação de outros bairros.

"Em Riviera não temos o que falar, está tudo bem!" (Morador de Riviera).

"Todos o bairros, menos Riviera e centro, o problema é saneamento, saúde, transporte" (Morador de Riviera).

Outras localidades são mencionadas somente naquelas oficinas em que os participantes procuraram dar um enfoque mais local aos problemas. Em outras oficinas, os participantes deram um enfoque mais municipal, não dando ênfase a problemas locais. O Sesc Bertioga, como imagem monumental, o centro da cidade e algumas localidades como Vicente de Carvalho II, Rio da Granja, Indaiá e Mangue Seco, como imagens compartilhadas, também se constituem como referências para os moradores.

"Centro(....) totalmente sujo, falta de higiene, esburacada, sem passeio, sem sinalização, ciclista não tem via" (Morador de Rio da Praia). 
"Sesc doou uma área para a construção de casas para o pessoal do Mangue Seco" (Morador de Rio da Praia).

"Tem muitos sonhos para Vicente de Carvalho II. Quem impediu foi a comunidade" (Participante no Delphino).

"O peixe mais gostoso de Bertioga eu encontrei no Mangue Seco, no Rio da Granja. O quer falta é conhecer Bertioga como um todo. Comprei pão também na favela do Indaiá" (Participante no Delphino).

Na Oficina regional, realizada na Riviera, havia alguns participantes de São Lourenço que consideraram a oficina um espaço para colocar suas reivindicaçōes referentes à educação, habitação, segurança, saúde, saneamento e transporte, conforme demonstram as falas que se seguem:

"Estão abrindo dois acessos do Riviera para o centro e nós não temos em São Lourenço" (Morador de Riviera).

"Em São Lourenço não tem segurança, entram por lá para Riviera" (Morador de Riviera).

"De São Lourenço ao Sesc demora uma hora e quinze minutos. Precisamos de ônibus mais direto" (Morador de Riviera).

Em outras oficinas participantes de outros bairros colocaram outros problemas/reivindicações:

“Jardim São Rafael precisa escola" (Morador de Riviera).

"Vista Linda e Indaiá tem problemas de favelas, precisa de casas populares" (Morador de Riviera).

“Guaratuba falta saúde, Boracéia saneamento” (Morador de Riviera).

Um candidato a vereador e participante de uma oficina em Rio da Praia coloca a necessidade dos bairros defenderem seus interesses.

"Temos que ser bairrista, defender o nosso bairro, o nosso canto".

Em geral, entretanto, percebe-se que não há uma identificação forte dos moradores com os bairros onde residem, fato que se comprova pela 
pouca menção das diversas localidades, em que moram os participantes das oficinas.

\section{A fragmentação do território}

Outro aspecto muito presente nas oficinas é a visão fragmentada que os moradores têm de Bertioga. Muitos, por exemplo, denominam o "centro" da cidade de Bertioga, como se o seu bairro também não fizesse parte do mesmo município.

“...só para lembrar, quando a gente tava pavimentando a Anchieta, eu vinha para Bertioga na hora do almoço" (Oficina do Futuro em Rio da Praia).

"Por exemplo, eu fiquei conhecendo a Laís que é lá de Bertioga, através do coral, a familia...através do coral!" (Oficina do Futuro em Riviera).

Essa fragmentação do município é provocada por barreiras geográficas, físicas, sociais, culturais e político-administrativas. As barreiras físicas são os muros do condomínios, os portais, a estrada Rio-Santos. A cidade é povoada por imagens compartilhadas que não permitem enxergar o outro lado da rodovia, do muro, do portal...

"Bertioga é muito extensa e assim você enxerga partes, os problemas da Bertioga não aparecem como um todo e sim por bairros" (Morador de Indaiá).

"Colocamos também a diferença entre os bairros: os condomínios fechados, e um aglomerado, que daqui também tem favela" (Morador de Boracéia).

Riviera densamente urbanizada que no futuro pode dar problemas, de água, esgoto. Boracéia que é menos urbana, também tem problemas - não tem rede de água tratada...esgoto tratado no centro e na Riviera, água tratada tem do lado de cá da pista - do lado de lá muito pouco.

"Rodovia, barreira fisica. Bertioga de lá para cá (separada pela rodovia)". 

lugar certo".

“... a Rio Santos é um marco desgraçado, nós temos que derrubar...você está no

As barreiras sociais são caracterizadas pela falta de acesso à educação, à saúde, ao emprego e aos serviços das diferentes camadas sociais de Bertioga, especialmente as que se referem à comunicação e informação marcando as grandes diferenças sociais entre a população que mora nos condomínios, do lado do mar e a que mora em favelas ou habitaçōes precárias do lado das montanhas, da área de preservação ambiental.

\begin{abstract}
Nesse desenho do futuro, esquecemos até a questão geográfica e não fizemos separação nenhuma. Não podemos referendar essa divisão que está acontecendo. Temos que atender toda a população. A gente tem que pensar na cidade como um todo. Entendemos quais são os problemas de Bertioga. Respeitar as diferenças. É uma cidade plana.
\end{abstract}

"Tem a questão fisica e social: estrada".

"Quem foi para lá não tinha possibilidade de comprar terreno aqui. Tem a estrada, mas não vejo viadutos e artérias. O lado de lá tem que se integrar. Levar movimento, restaurante".(participante do grupo de Delphino)

"Tem que levar informação. Lá não chega nada. A questão do lado de lá e do lado de cá, não é física, é moral. Quem morar do lado de lá, cuida dos filhos do pessoal daqui. Bertioga não tem identidade" (Participante no Delphino).

"... grande contraste das classes sociais" (Morador de Indaiá).

“...desemprego" (Morador de Indaiá).

A grande questão que a construção civil e seus trabalhadores trazem para o município é mencionada de passagem demonstrando uma falta de atenção dos municipes em relação ao problema.

“Na construção civil, os trabalhadores foram aproveitados e depois abandonados, não houve uma contrapartida social" (Participante no Delphino). 
As barreiras culturais são as provocadas pelas diferenças existentes entre os diversos segmentos que compõem a população de Bertioga, caiçaras, nordestinos e turistas.

"O caiçara tem medo de turista, perdeu suas áreas para os ricos, teve que morar em outras áreas. Com esse crescimento a população invade tudo" (Participante no Delphino).

As barreiras políticas são a recente emancipação do município e a inexistência de abairramento ou um enfoque administrativo mais descentralizado, com acesso de serviços a todas às localidades de Bertioga. A centralização administrativa e a valorização do Centro - como a Bertioga promove também a centralização dos recursos para investimentos.

"A maioria daqui não tem endereço - não podemos receber correspondência" (Morador de Boracéia).

... e eu sinto que quando falam integração, não só da Riviera mas de Bertioga como um todo, e é uma cidade que não tem integração e é uma cidade que é difícil de fazer um monte de coisa, você não consegue reunir as pessoas, muita coisa não dá certo, e todo mundo reclama aqui, principalmente a Riviera, mas ninguém quer fazer alguma coisa pra melhorar isso. (Oficina do futuro em Riviera).

É porque aqui em Bertioga, é considerado até o Sesc, fora do Sesc em diante, são Bertioguinhas. Então, por exemplo, Indaiá dentro da cidade chega alguma comunicação mais fácil, mas até Boracéia... tá um show lá no centro Bertioga, e Boracéia não está sabendo" (Oficina do Futuro em Indaiá).

\section{Olhares diversos dos diferentes atores}

Quanto ao processo de negociação de consensos, a participação dos diversos atores sociais no processo do planejamento nas Oficinas do Futuro constituiu-se, por si só, em resultado positivo, além dos resultados e produtos obtidos nas oficinas.

Durante as Oficinas do futuro, por se constituírem como um espaço de discussão livre e aberto, foi possivel que os participantes colocassem 
suas percepções sobre os diversos aspectos dos temas. Algumas vezes, essas percepções foram recorrentes e, outras vezes, diferenciadas.

Não houve, a princípio, manifestaçāo aberta de conflitos de interesses, mas sim diferenças expressas de conflitos latentes, que durante o processo de negociação de consensos foram sendo aprofundados, esclarecidos e, em algumas ocasiōes, reservados para discussões posteriores.

Uma das questōes em que esta diferença aparente de enfoques teve um papel de destaque foi a discussão o "conflito" entre qual seria a forma de atuação preferencial em relação aos problemas, conforme demonstram as falas que se seguem.

Uma grande maioria foi a favor de que as ações fossem pensadas para todo municipio.

"Os trabalhos que são feitos hoje não são representativos para o todo de Bertioga" (Morador do Delphino).

Outros defenderam ações locais:

“...então eu gostaria não só Bertioga, como eu estou desenvolvendo, mas com o bairro em si também, todos esses problemas que estão sendo postos ai fossem solucionados na falta de vontade política" (Oficina do Futuro Rio da Praia).

- Então, a pergunta que eu quero fazer é: qual é o pedaço de vocês? Como é que, por exemplo, se eu chamo vocês de um grupo, como é que vocês querem ser chamados? Vocês representam que pedaço de Bertioga?

- ...que pedaço de Bertioga?

- Porque assim... o grupo de Bertioga é grande demais.

- Nós estamos preocupados com toda a Bertioga, né?!"

(Diálogo em uma Oficina do Futuro em Jardim Rio da Praia)

Outro tema polêmico conflituoso e contraditório que marcou as Oficinas do Futuro foi a representação sobre o Condominio Riviera de São Lourenço para a população de Bertioga. A Riviera constitui-se para muitos, numa imagem compartilhada do desejo projectual de ascensão a uma vida 
melhor. Seus conjuntos de prédios formam um bloco homogêneo de uma imagem monumental que estaria enraizada na história da cidade.

"Toda cidade tem que se tornar uma Riviera" (Morador de Indaiá).

Ao mesmo tempo, há uma outra imagem compartilhada que representa o conflito e a contradição gerada por este projeto de qualidade de vida. A medida que foi gerada uma possibilidade concreta deste ideal para um segmento da população - a maior parte de uma classe média alta foram criadas condiçōes de ampliação das iniqüidades locais que no momento começam a gerar problemas como a insegurança e a violência expressando com isto a consciência da contradição que o bairro representa. Seus moradores mudaram para lá em busca de melhoria de qualidade de vida e já têm manifestado a consciência de que podem estar no meio de "um fogo cruzado".

"A Riviera é modelo, mas gerou favelas, os trabalhadores do empreendimento" (Morador de Boracéia).

"Contraste Riviera tão rica e Bertioga sem estrutura, quando a obra termina, os trabalhadores fazem os barracos próximo à Riviera, aumentando as favelas do bairro Indaià" (Morador de Indaiá).

Nós temos situações bem distintas em Bertioga, nós temos hoje uma Riviera de São Lourenço, onde o padräo de vida é altíssimo, onde tem rede de esgoto, tem segurança, tem tudo que apresenta de bom, enquanto nós temos do nosso lado de cá, uma situação onde falta segurança, onde o saneamento básico é precário, onde falta iluminação nas ruas, então isso em virtude de que, uma má distribuição de renda, onde as pessoas lá têm apartamento, às vezes utilizam o apartamento uma vez por ano. Năo é que essas pessoas não têm direito, fizeram, devem ter merecido ter esses apartamentos, mas cadê o outro lado daqui, nosso outro lado, onde falta habitação, onde a gente não tem moradia. (Participante no Delphino).

Uma moradora do Riviera manifesta sua queixa em relação a um certo preconceito existente dos outros bairros com relação à Riviera.

E como é um municipio muito grande, comprido, com vários bairros afastados um do outro, então a gente fica assim meio ilhado, cada bairro. Nesse sentido de centro com bairro, com um poder aquisitivo maior, então a 
gente tem um pouco disso aqui, de preconceito que os outros tem contra a gente (moradora do Riviera)

Outro tema também relacionado a este e recorrente foi a preocupação com o crescimento populacional de Bertioga e o surgimento das favelas.

As favelas, em contraponto ao Condomínio Riviera de São Lourenço, representam a imagem compartilhada do preconceito, da pobreza, da ocupação irregular, do banditismo. Alguns participantes, porém, percebem o valor dos moradores das favelas. Enfim, a questão do julgamento do significado das favelas para Bertioga foi outro tema polêmico durante as oficinas.

"Por que, a favela faz com que, o progresso indo embora e a favela chegando cada vez mais, antes era uma, agora são três favelas, quer dizer, ela está crescendo mais que o progresso" (Oficina do Futuro em Boracéia).

"...existe sim da favela um grupo, um movimento que está liderando vários tipos de drogas, então vai incentivando as crianças a usarem droga, então eu sou contra a favela $\operatorname{sim}^{\prime \prime}$ (Oficina do Futuro em Boracéia).

“Comerciantes são desunidos, não se ajudam, na favela tem mais união" (Oficina do Futuro em Boracéia).

"...essa associação tem que ser passada desde o começo, para nós sabermos os nossos direitos. Muita gente que mora na favela faz Bertioga" (Oficina do Futuro em Delphino).

"Assim a gente não se sente tăo nada, tão ninguém. Quem mora em favela é discriminado" (Oficina do Futuro em Delphino).

Não há concordância a respeito de como o problema pode ser resolvido. $O$ debate se dá no sentido de colocar ou não infraestrutura urbana, onde se desenvolveram as favelas. Alguns se manifestaram contrariamente, como este morador de Boracéia.

Eu peço discurso porque eu tenho pensamento radical, eu acho que se nós dermos condiçōes para a favela, se a gente coloca luz na favela, se a gente coloca saneamento na favela a gente acaba incentivando a favela, por isso que eu estou colocando esse pensamento radical que eu tenho, mas é esse meu pensamento. (Oficina do Futuro em Boracéia). 
Outros se posicionaram menos radicalmente, porém contrariamente:

...eu nāo coloquei para colocar o saneamento nas favelas, mas é que para melhorar a qualidade de vida dos moradores, porque eu percebo que onde tem a falta de saneamento é nas favelas principalmente. Então eu acho que deveria colocar saneamento, não nas favelas por que é onde falta, mas sim para todos, para năo haver isso, entendeu? (Oficina do Futuro em Boracéia).

Todos concordam que algo deve ser feito para solucionar o problema das favelas, impedindo o aumento de área ocupada nos núcleos já existentes.

"Nós vemos que tem que bloquear a favela, em respeito ao que vocês conseguiram ruas bem feitas, casas confortáveis" (Oficina do Futuro em Delphino).

"As invasões tem que diminuir" ( Oficina do Futuro em Delphino).

“..núcleos habitacionais na favela"(Oficina do Futuro em Delphino).

Outro ponto polêmico é a questão da visão sobre e do tratamento a ser dispensado aos denominados "turistas de um dia". Estes, apesar de serem em grande número, rendem pouco para a economia do município. Ao contrário, eles dão prejuizo na medida que nāo consomem, invadem e sujam tudo, especialmente a praia.

"Eu não sei se é o turismo que segura Bertioga. Eles não consomem nada na cidade, só sujam e vão embora. Tem que ter guarda na praia. O farofeiro gasta na praia" (Participante no Delphino).

"Eu prefiro um farofeiro deixar esse tipo de lixo -sucata - do que a madame que deixa o cachorro fazer coco na praia e meu filho pegar doença" (Participante no Delphino).

"O farofeiro é visto como ruim. A gente tem que ver aquela pessoa que vem, aquele é o único lazer dele. Năo podemos fazer igual como os moradores de Riviera ou Morada do Sol" (Moradora de Boracéia).

"Mas eles vêm ao meu restaurante" (Moradora de Boracéia). 
Porém, todos concordam que o turismo, mesmo que seja impactante sobre o meio ambiente, constitui-se em uma das alternativas para o municipio, sendo necessário que haja uma preparação para a boa acolhida dos turistas, conciliando a geração de renda com a preservação do meio ambiente.

"Temos que nos preparar para o turista voltar" (Morador do Riviera).

"O turismo pode trazer uma gama muito grande de empregos para Bertioga...turismo bem feito - ecoturismo" (Morador de Rio da Praia).

"Turismo traz dinheiro. Temos que receber o turista e dar formas para que ele não destrua a cidade" (Participante no Delphino).

"Grande potencial é o turismo" (Morador de Boracéia).

Durante as oficinas realizadas com o grupo de Rio da Praia, que era constituído em sua maioria por migrantes da Bahia, e no grupo da Riviera, o assunto turismo foi sequer mencionado. Um morador participante de outra oficina coloca também que se deve pensar em outras formas de geração de renda.

"Emprego para os moradores: a cidade năo pode ser movida exclusivamente pelo turismo" (Morador de Rio da Praia).

\section{Pontos de vista diferentes: conflitos e negociação de acordos e propostas de ações}

A busca de consensos se dá em diversos momentos durante a realização das Oficinas do Futuro. Alguns desses momentos preparatórios para a elaboração da agenda final de prioridades locais foram, por exemplo, durante a primeira oficina realizada em cada grupo, a busca de consenso quanto a quais problemas deveriam ser agrupados, quanto ao nome a ser dado às nuvens de problemas similares, quanto às prioridades a serem discutidas e/ou colocadas na agenda, quanto ao acordo de convivência, quanto à continuidade do grupo e quanto às datas de novas reuniöes. Nas 
oficinas posteriores, outros momentos foram surgindo, culminando na elaboração das agendas e na sua apresentação durante o / Seminário Municipal do Projeto Bertioga Município Saudável.

Analisando-se as quatro oficinas realizadas com o "Grupo do Futuro" de Rio da Praia, pode-se destacar alguns dos seus momentos.

Um exemplo de consenso de agrupamento de problemas ocorre no início da primeira oficina no seguinte diálogo.

- José Matias também! Alguém pensou diferente disso? Nós podemos agrupar trabalho, com emprego, e falta de emprego? Podemos por no mesmo grupo de problema? (Coordenadora da oficina).

- Pode! (Alguns participantes da plenária).

Um exemplo de consenso de nomenclatura das nuvens de problemas é colocado no seguinte diálogo.

- Podemos chamar esta nuvem aqui do nome saneamento básico? (Coordenadora da oficina)

- Isso! (Um participante)

- Vocês estão de acordo? (Coordenadora da oficina)

- É! (Vários participantes)

O acordo de convivência são normas definidas coletivamente pelo grupo para o bom funcionamento das oficinas. Esses acordos foram elaborados e avaliados constantemente nos sete grupos acompanhados durante as oficinas.

O acordo elaborado pelo Grupo do Futuro teve em sua composição os seguintes itens:

1. Que todos compareçam a todas as reuniōes.

2. A união de idéias.

3. Convidar novas pessoas, que vão ser esclarecidas sobre a reunião anterior às $18 \mathrm{~h} 30$. 
$\mathrm{Na}$ terceira oficina, esse acordo foi avaliado e, após constatação que um dos itens não havia sido cumprido, foi eliminado pelo grupo.

- ...bom, o primeiro acordo, que todos participem. (Coordenadora da oficina).

- Já está furado. (Uma participante).

- Porque dona Maria? (Coordenadora da oficina).

- Porque tem muita gente faltando. (Uma participante).

- ... Convidar novas pessoas que vão ser esclarecidas quanto à outra reunião anterior, às $18 \mathrm{~h} 30$, isso não né, não está acontecendo, vamos fazer ou não?

- Não! (Uma participante).

- Não, então vamos tirar, agora aqui, não vamos mais convidar pessoas? Convida! Então vamos tirar esse aqui, só convidar novas pessoas, início do trabalho as $19 \mathrm{h00}$, que a gente está tentando manter. (Coordenadora da oficina).

$\mathrm{Na}$ terceira oficina realizou-se um sociograma, utilizando-se de círculos vermelhos e verdes em dois tamanhos, para representar os diferentes atores sociais envolvidos nos problemas. Em um certo momento, após o posicionamento, foi possível visualizar um agrupamento de diversos círculos, que representavam os participantes da oficina.

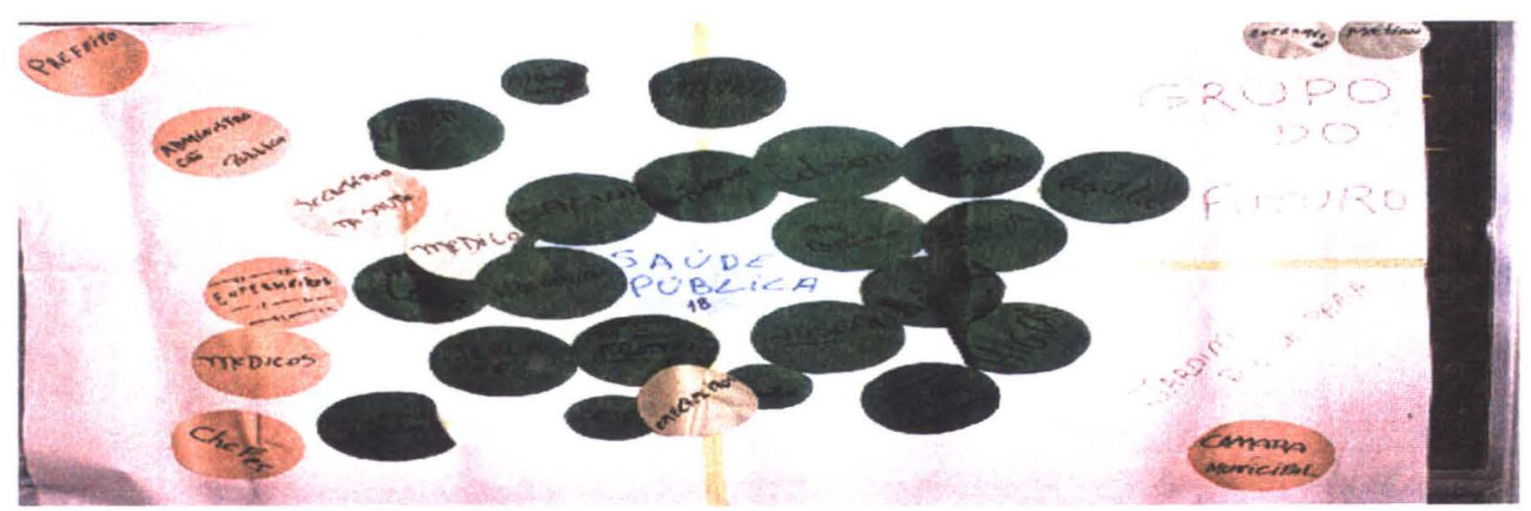

FOTO 8: SOCIOGRAMA COMO GRUPODOFUTURO

-...o que mais que mostra isto? Porque será que a gente está assim tudo meio entrelaçado... Mas porque está acontecendo isso? Porque vocês estão tão, todos juntos? (Coordenadora da oficina).

- Porque está tudo mundo querendo participar, se envolver o mais possível. (Uma participante).

- Que está mostrando que vocês na verdade se aproximaram, olha aqui, aqui formou quase uma cadeia. (Coordenadora da oficina). 
Nem sempre se atingia o pleno consenso e, nessas situações, adiavase essa discussão ou a coordenação propunha um encaminhamento. $\mathrm{Na}$ discussão acerca de qual nome o grupo deveria ter, houve várias sugestōes: "Bairro melhor", "Saúde na praia", "Saúde do bairro", "Praia saúde", "Grupo sem palavras", "Grupo da Família Reunida", "Grupo Praia melhor", "Por um Rio da Praia melhor", "Saúde maior", "Rio da Praia de Terça-feira" e "Grupo Grande do Futuro". Essas discussōes permearam vários momentos da oficina, mas somente na última parte é que o grupo chegou em um consenso.

- "Grupo do Futuro, a Dalva deu uma idéia, está bom? (Coordenadora da oficina).

- Está bom!" (Uma participante).

No final da quarta oficina, a construção da agenda de prioridades locais do "Grupo do Futuro" foi concluída e resultou no seguinte quadro:

\begin{tabular}{|l|l|l|}
\hline \multicolumn{1}{|c|}{ Grupo } & \multicolumn{1}{|c|}{ Prioridades } & \multicolumn{1}{c|}{ Ações sugeridas } \\
\hline Grupo do Futuro & $\begin{array}{l}\text { Saúde Pública } \\
\text { Desemprego }\end{array}$ & $\begin{array}{l}\text { Reunir o grupo para dar soluçōes imediatas } \\
\text { para resolver o problema da saúde que está } \\
\text { afligindo a comunidade a começar c/ a } \\
\text { Associação do bairro, discutindo o problema, } \\
\text { e seu fortalecimento através de divulgação } \\
\text { ampla (jornais e rádio) } \\
\text { Organização do grupo através de reuniões } \\
\text { marcadas } \\
\text { O grupo deverá agir cobrando do poder } \\
\text { público através de reuniōes } \\
\text { Formar uma comissão do grupo e levarmos } \\
\text { até a câmara municipal os problemas, } \\
\text { aguardar a solução em curto prazo e uma } \\
\text { posição sobre mesmo mo }\end{array}$ \\
\hline
\end{tabular}

As prioridades locais contidas nas agendas definidas pelos outros grupos foram: 


\begin{tabular}{|l|l|}
\hline \multicolumn{1}{|c|}{ GRUPOS } & \multicolumn{1}{|c|}{ PRIORIDADES } \\
\hline Grupo da Vila & $\begin{array}{l}\text { Educação } \\
\text { Saúde }\end{array}$ \\
\hline $\begin{array}{l}\text { Grupo Novas Idéias, Antigos } \\
\text { Problemas }\end{array}$ & $\begin{array}{l}\text { Saúde } \\
\text { Insegurança } \\
\text { "Sujeira" } \\
\text { Educação }\end{array}$ \\
\hline Grupo Indaiá & $\begin{array}{l}\text { Falta de união dos moradores } \\
\text { Descompromisso do poder público }\end{array}$ \\
\hline Grupo Jardim Paulista & $\begin{array}{l}\text { Descaso ambiental } \\
\text { Desrespeito à população local }\end{array}$ \\
\hline Grupo Riviera Saudável & $\begin{array}{l}\text { Saúde } \\
\text { Drogas }\end{array}$ \\
\hline Grupo Guara-Bora Bora-Guara & $\begin{array}{l}\text { Falta de união dos moradores } \\
\text { Falta de lazer } \\
\text { Drogas (criminalidade) } \\
\text { Favelas }\end{array}$ \\
\hline
\end{tabular}

A saúde foi priorizada por quatro grupos, revelando-se a principal questão a ser trabalhada. A educação, o problema das drogas e a falta de união dos moradores foram priorizados por dois grupos. Essas prioridades coincidem com o quadro relativo aos problemas levantados anteriormente na Pesquisa Exploratória e nas Oficinas Regionais. $O$ desrespeito à população local e o descompromisso do poder público aparecem como prioridades menos citadas anteriormente, pelo menos de uma forma mais explícita. 0 saneamento básico deixa de figurar como prioridade dos grupos, talvez por ser um problema envolvendo outras esferas além do poder municipal.

\section{Sonhos: uma utopia norteadora}

No gráfico 10 estão colocados os sonhos dos entrevistados durante a Pesquisa Exploratória, que passaremos a analisar. 


\section{Gráfico $10-N^{\circ}$ de ocorrência dos sonhos mencionados pelos entrevistados no levantamento de lideranças. \\ Os 15 mais citados - Bertioga - 04/2000}

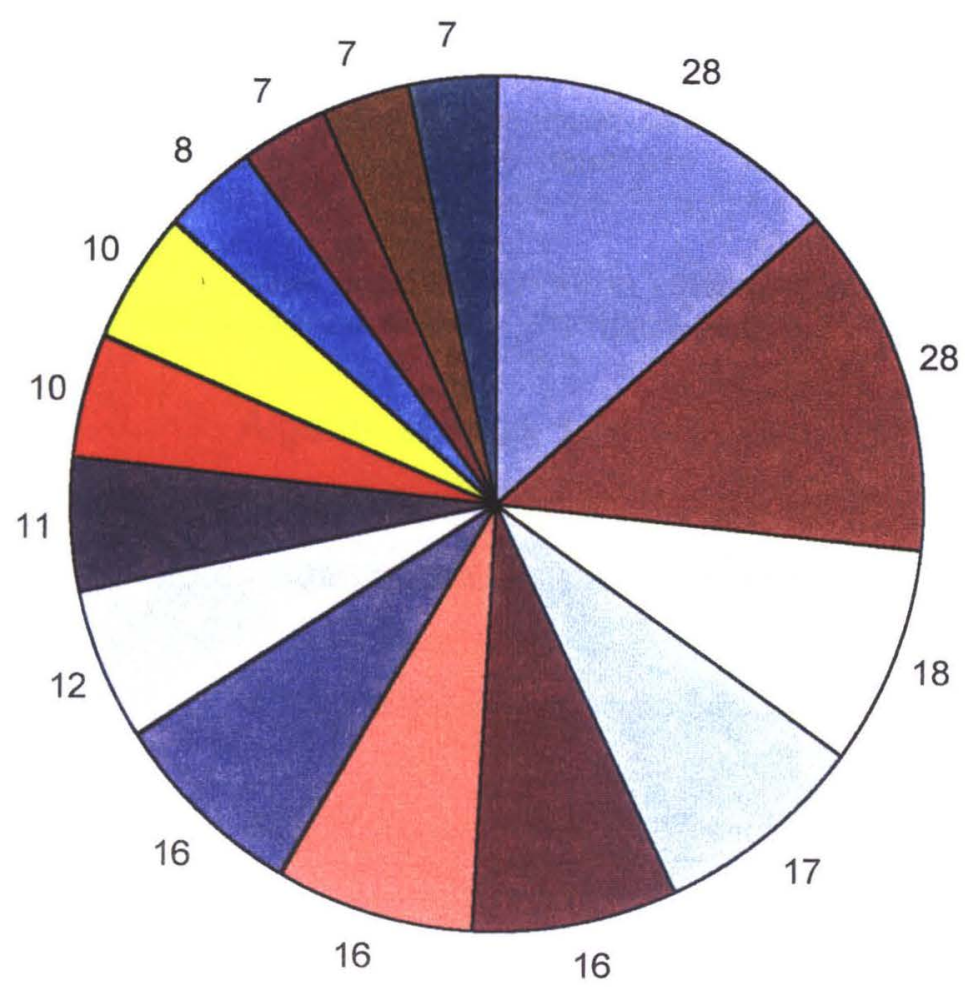

$\square$ Relacionados à administração pública atual (28)

QRelacionados ao turismo (28)

$\square$ Relacionados à geração de emprego e renda (18)

$\square$ Relacionados ao atendimento à saúde pública (17)

- Relacionados ao desenvolvimento da cidade (16)

$\square$ Relacionados ao ensino público ou privado (16)

口 Relacionados à habitação (16)

- Relacionados à melhoria de infraestrutura e preservação das praias (12)

- Relacionados à preservação do meio ambiente (11)

$\square$ Relacionados à melhoria e conservação da infra-estrutura nos bairros (10)

$\square$ Relacionados à planejamento urbanístico da cidade (10)

$\square$ Relacionados ao crescimento econômico (8)

Q Relacionados ao saneamento básico (7)

- Relacionados à melhoria de qualidade de vida (7)

Relacionados às condições

sócioeconômicas da população (7)

O Gráfico 10 demonstra que $11,09 \%$ dos entrevistados, que correspondem a 28 de um total de 254 citações, sonham com mudanças relacionadas à administração atual e/ou futura, sendo este uma das maiores expectativas.

Alguns sonhos citados pelos entrevistados durante a pesquisa exploratória mostram suas expectativas relacionadas à administração vigente e futura que não parecem muito difíceis de serem atingidos. Querem um prefeito honesto que consiga resolver o problema de emprego e diminuir as iniqüidades. A intersetorialidade, um dos pressupostos do município 
saudável sequer foi vislumbrado demonstrando que esta prática não faz parte ainda do repertório de possibilidades de inovação a ser implementada na administração pública. exploratoria)

“Uma prefeitura 'café com leite' simples e honesta" (participante da Pesquisa

"Fosse linda, se aposentasse e pescasse o dia todo; geração de emprego e resolvesse os problemas, olhassem para as pessoas simples, que são a maioria, se saia dos gabinetes" (participante da Pesquisa exploratória)

"Que a população saiba votar e que elejam representantes para o municipio que tenham capacidade para isso" (participante da Pesquisa exploratória)

Alguns sonhos são de natureza mais individualista, e abrangem sonhos relacionados com uma ascensão econômica, social e política, e um simples desejo de uma moradia mais decente.

"Morar dentro do Riviera de São Lourenço" (participante da Pesquisa exploratória)

"Meu sonho é ser vereador" (participante da Pesquisa exploratória).

"Casa melhor, bem arrumada - não dá para fazer banheiro porque não tem material" (participante da Pesquisa exploratória)

Outros sonhos que se destacam são os relacionados ao turismo, com 28 citações ou $11,09 \%$ do total, o que indica uma saída esperada para o problema do emprego em Bertioga.

Nas Oficinas Regionais os sonhos envolvendo a melhoria do turismo sempre são destacados.

"Portal, palmeiras imperiais, orelhões funcionando, recepção para o turista" (Morador do Indaiá). Praia).

"Praias sujas - precisa de estrutura para receber o turista" (Morador de Rio da

"Grande potencial é o turismo o melhoria de orlas, quiosques- ciclovias urbanização - melhorias nas rodovias - mais passarelas - um hospital " (Morador de Boracéia). 
O terceiro grupo de sonhos são os relacionados à outras formas de geração de emprego e renda, o qual tem ligação direta com o turismo, e que somados atingem 46 citações ou $18,16 \%$ do total.

É interessante observar que mesmo reconhecendo que o saneamento básico é considerado como principal problema pelos entrevistados, ao falarem dos sonhos para Bertioga, esse problema é mencionado a partir do oitavo grupo de sonhos relacionados à melhoria da infra-estrutura e preservação das praias.

Estes resultados parecem indicar que na percepção dos entrevistados os sonhos sugerem mudanças de médio e longo prazo, sentimentos mais interiorizados, e os problemas indicam as questōes mais "imediatas", aquelas questões que são "sentidas mais na pele". Os sonhos orientam 0 caminho, mas são as prioridades que definem as ações. Esta idéia parece nortear os grupos participantes das oficinas, que percebem que uma mudança administrativa é uma das principais soluções para a resolução dos problemas da cidade.

Um participante da última oficina do futuro, do "Grupo do Futuro", fez um relato emocionado de seu sonho:

\footnotetext{
Um sonho, ....... então esse sonho, é, essa noite eu tive um sonho, quero Ihe contar, sonhei que todo mundo tinha casa para morar, não havia mais mendigo, nem pessoas a roubar, todos eram bons amigos, pareciam se amar, eu sonhei que não havia mais a guerra, que só havia paz na Terra, era somente o dia oh, eu sonhei. Eu sonhei que um dia muita gente, todos diziam, para mim, vocês são meus irmãos, de manhã, de manhăzinha, quando estou a despertar, a campainha soou a tocar e um mendigo a pedir, olho, olho para o mundo e não quero aceitar, tô emocionado, desta que era um sonho que eu não quis acordar".
} 


\section{Uma tentativa de sistematização}

A Tabela 8, a seguir, é uma tentativa de sistematização de alguns resultados obtidos durante a Pesquisa Exploratória, as Oficinas Regionais e as Oficinas do Futuro. 
Tabela 8 - Sistematização dos principais problemas, lutas dos grupos e organizaçōes, prioridades e dados de participação quantitativa por áreas do municipio. Bertioga. 2000.

\begin{tabular}{|c|c|c|c|c|c|c|c|c|}
\hline \multirow[t]{2}{*}{ Área } & \multirow[t]{2}{*}{\begin{tabular}{|l|} 
Problemas \\
principais
\end{tabular}} & \multirow[t]{2}{*}{$\begin{array}{lr}\text { Lutas } & \text { das } \\
\text { entidades } & 0 \\
\text { grupos } & \\
\end{array}$} & \multirow[t]{2}{*}{\begin{tabular}{|l|} 
Prioridades \\
nas Oficinas \\
do Futuro
\end{tabular}} & \multirow[t]{2}{*}{ Sonhos } & \multicolumn{4}{|c|}{$\begin{array}{l}\text { Número de } \\
\text { entrevistados/participantes/membros/entidad } \\
\text { es }\end{array}$} \\
\hline & & & & & PE & OREOF & $\begin{array}{l}\text { Comissão } \\
\text { Intersetorial } \\
\text { de 2001 }\end{array}$ & Entldades \\
\hline$T(A)$ & $\begin{array}{l}\text { Saneamento } \\
\text { e limpeza } \\
\text { pública }\end{array}$ & \begin{tabular}{|l|} 
Recreação, \\
cultura, \\
educação, \\
melhorias \\
urbanas, \\
regularização \\
fundiária, \\
religião e e \\
saneamento \\
\end{tabular} & $\begin{array}{l}\text { Educação, } \\
\text { saúde, meio } \\
\text { ambiente e } \\
\text { cidadania }\end{array}$ & & 42 & 100 & 3 & 37 \\
\hline II (B) & \begin{tabular}{|l|} 
Saneamento \\
e limpeza \\
pública
\end{tabular} & \begin{tabular}{|l|} 
Saneamento, \\
saúde, \\
turismo e e \\
recuperação \\
das drogas.
\end{tabular} & \begin{tabular}{|l|} 
Saúde, \\
limpeza \\
pública, \\
educação, \\
emprego e \\
segurança \\
\end{tabular} & & 27 & 94 & 3 & 12 \\
\hline III (C) & $\begin{array}{l}\text { Saneamento } \\
\text { e limpeza } \\
\text { pública }\end{array}$ & \begin{tabular}{|l|} 
Educação, \\
recreação, \\
cultura, \\
melhorias \\
urbanas, \\
regularização \\
fundiária e \\
meio \\
ambiente \\
\end{tabular} & $\begin{array}{l}\text { Desuniăo e } \\
\text { cidadania }\end{array}$ & & 33 & 54 & 2 & 18 \\
\hline IV (D) & $\begin{array}{l}\text { Saneamento } \\
\text { e segurança }\end{array}$ & \begin{tabular}{|l|} 
Assistência \\
social, \\
educação, \\
melhorias \\
urbanas, \\
regularização \\
fundiária, \\
meio \\
ambiente e \\
saneamento
\end{tabular} & \begin{tabular}{|l|l|} 
Saúde & e \\
drogas &
\end{tabular} & & 22 & 36 & 2 & 14 \\
\hline $\mathrm{V}(\mathrm{E})$ & $\begin{array}{l}\text { Saúde } \mathrm{e} \\
\text { saneamento }\end{array}$ & \begin{tabular}{|l|l|} 
Assisténcia & \\
social, & \\
educação, & \\
saúde, & \\
correio & e \\
limpeza & \\
pública & \\
\end{tabular} & $\begin{array}{l}\text { Desunião, } \\
\text { lazer } \\
\text { drogas } \\
\text { favelas }\end{array}$ & & 14 & 48 & 0 & 11 \\
\hline Municipio & $\begin{array}{l}\text { Saneamento } \\
\text { e saúde }\end{array}$ & $\begin{array}{l}\text { Saneamento, } \\
\text { melhorias } \\
\text { urbanas } \\
\text { regularização } \\
\text { fundiária e } \\
\text { educação }\end{array}$ & & $\begin{array}{l}\text { Administração } \\
\text { pública atual e } \\
\text { turismo }\end{array}$ & 138 & 332 & 10 & 92 \\
\hline
\end{tabular}


Os resultados da Tabela 8 demonstram que, quantitativamente, a região do centro possui maior número de grupos, organizações e "lideranças", sugerindo um maior potencial quanto à participação, que se reflete no número de participantes das atividades desenvolvidas pelo Projeto Bertioga Municipio Saudável, em 2000. Outro aspecto que pode ser salientado è o fato de que, à medida que se afasta do centro (áreas IV e V), as lutas das organizações e grupos localizadas nessas áreas passam a ser relaçionadas à assistência e à promoção social, indicando uma maior carência no tocante às necessidades materiais, ao passo que, nas áreas próximas ao centro, estão relacionadas ao lazer e à cultura.

Outro aspecto a ser salientado é o fato de que as áreas 111 e $\mathrm{V}$ colocam como suas prioridades a questão de melhorar a união dos moradores, o que mostra que a fragmentação ocorre não somente no plano municipal, mas no plano local.

Nas áreas I e III, os sonhos de uma mudança na administração pública acabam norteando a escolha de prioridades, no caso, a cidadania, como uma busca de uma maior participação, sugerindo o desejo de seus moradores, de uma maior competência política (DEMO 2000 p. 7). 


\title{
CAPÍTULO 8
}

\author{
RELAÇÃO DOS RESULTADOS \\ COM O REFERENCIAL TEÓRICO \\ - PARTICIPACÃO SOCIAL E \\ CIDADE SAUDÁVEL
}


Esta dissertação se propôs a analisar a participação da sociedade civil na formulação e implantação do Projeto Bertioga Municipio Saudável. Os conceitos de participação social e de cidades/municípios saudáveis já apresentados no capítulo 2 e outros referenciais da literatura acumulados sobre estes dois temas vão orientar a discussão dos resultados.

Consideramos fundamental analisar e discutir os resultados apresentados, após o primeiro ano de atividades a partir desta literatura. Para realizar tal intenção, efetuou-se uma sistematização das citações de alguns participantes quanto aos conceitos de participação e cidade saudável; o efeito e a influência das metodologias participativas na atuação desses participantes e a verificação se os objetivos das Oficinas do Futuro foram atingidos.

Com relação aos conceitos de participação e cidade saudável, o primeiro, foi vivenciado e o segundo, intensivamente trabalhado. Pudemos perceber algumas definiçōes e idéias do ponto de vista de alguns participantes que se afastam do conceito adotado nesta dissertação.

Alguns participantes colocam o conceito de participação de um ponto de vista assistencialista, como pode ser observado na frase desta participante:

... então a gente tem uma vida bem atuante lá entendeu, principalmente tendo um filho vereador que a gente acaba assessorando, então a gente tem uma atividade assim bem acentuada e a gente acode, tudo o que é preciso, é uma campainha que toca o dia todo, as pessoas pedindo ajuda, orientação, indicaçōes para alguma coisa e a gente está sempre a postos sempre tentando ajudar do melhor modo possivel. (IVPL).

Há outros e muitos que se aproximam do adotado por FOREST et alli, citado por RUIZ (1998, p. 13), conceito que se aproxima da idéia de parceria da população com o governo. 
"Nâo sobrecarregar a prefeitura cada um participando e colaborando com a cidade" (Morador do Indaiá).

\begin{abstract}
... . que a gente quer para a nossa cidade, o que a gente pode fazer de imediato, tentar elaborar essas questōes e viabilizar junto com a administração, o poder público e a sociedade também dando o seu, a sua colaboração enquanto morador, por que não fica só na mão do poder público e nem na universidade em trazer as propostas mas eu acho que 0 cidadão tem que colaborar também, tem que participar. (MLP).
\end{abstract}

Outros participantes destacam a participação como um direito e um dever, conceito destacado por DALLARI (2001), que também faz uma aproximação com o conceito de parceria, aliança da população com o governo.

... nosso sonho é uma comunidade no bairro. A gente só fala em reclamar. Levar o conhecimento para os grandes. Nós só não sabemos. A comunidade tem que trabalhar. Assim a gente sofre menos. Essa associação tem que ser passada desde o começo, para nós sabermos os nossos direitos. (Moradora de Vicente de Carvalho).

... temos o direito de cobrar. Nós nos omitimos. Este trabalho é mais do que importante. Deve ter a participação da comunidade. A união de esforços é que leva ao sucesso. O poder público se năo tiver a condiçăo, o povo pode ajudar. É muita coisa errada. Então eu falo, gente nós não vamos ficar quietos. Temos que falar, todos tem que falar. (Morador de Rio da Praia).

“... Sua voz não tem que parar aqui. Tem que chegar na prefeitura. Tem gente muito boa em Bertioga que está envelhecendo sem fazer nada...que podem contribuir" (Participante no Delphino).

A idéia de participação relacionada à protagonismo, destacada por RUIZ (1998) e WESTPHAL (1997), fica evidente no discurso de alguns participantes:

“... nós sabemos quais são os problemas e precisamos participar das soluções" (Participante no Delphino).

Uma outra participante reforça a necessidade de organização das pessoas para que haja participação:

... Por participação, todo mundo acaba participando de um jeito ou de outro mas tem que buscar mesmo isso, buscar os meios, buscar onde estão os 
grupos, ou procurar nas associações de bairros, estar atento a qualquer tipo de envolvimento na cidade e fazer parte. (MLSM).

Consideramos que apesar da diversidade de conceitos ao longo do processo, as pessoas que foram permanecendo e outras que foram se agregando partilharam deste conceito de participação no sentido de construção conjunta ou concretização do ideal de cidade com melhoria das condiçōes de vida. Os participantes também orientados por este conceito foram deixando a dependência dos agentes externos da universidade e aos poucos estão se encaminhando no sentido da autonomia. A aliança e parceria com o governo foi um conceito que embora desejado, teve e está tendo problemas de concretização devido à mudanças de governo, que ocorreram no final do primeiro ano de atividades do projeto.

Quanto ao conceito de cidade saudável, os participantes o relacionam com a melhoria da qualidade de vida, melhoria dos serviços, conceito próximo ao preconizado pela Organização Mundial de Saúde (1995):

"Temos toda infra-estrutura, belezas naturais, porém os serviços encontram-se com precariedade, falta organizaçăo em todos os setores para que Bertioga seja um municipio saudável." (Morador de Indaiá).

... para a gente ter melhor qualidade mesmo em tudo, no saneamento, no estudo, (....) a qualidade de vida saudável é isso, a gente poder ter, tentar viver harmonicamente numa cidade, querer o melhor nessa cidade para si, desde a área de turismo, meio ambiente, educação enfím em tudo. (MLP).

... na vida profissional principalmente porque a gente começa a trabalhar mais especificamente com a qualidade de vida, tudo o que a gente vai falar com relação a preservação e prevenção já é nesse sentido, o que você faz, - que nós podemos fazer, o que nós podemos fazer no bairro, o que nós podemos fazer próximo a nossa casa para que possa melhorar o municipio então sempre sem querer a gente acaba tendo essa visão mais ampliada de qualidade de vida. (MLSM).

A idéia da cidade saudável relacionada à de prevenção à doença, nos termos de CERQUEIRA (1997), também se evidencia nesses discursos:

"É prevenir a doença antes que ela venha." (Morador de Rio da Praia). 
... Ah! Nós não temos posto, nós não temos médicos, aí, de repente, eles começavam a pensar, mas pera aí, o que a gente pode fazer não só para a gente ter médico e ter posto, o que a gente pode fazer para não ter tanta doença, e o trabalho de prevenção que eu acho que começou a ficar consciente na cabeça deles (MLSM)

Alguns aspectos subjetivos também se fazem presentes na fala de alguns participantes:

"Auto valorização, auto estima, saúde. Um povo que se valoriza, não é doente" (Participante no Delphino).

"Municipio saudável é municipio feliz." (Participante no Delphino).

No discurso dessa participante, a união do poder público e da sociedade civil pode gerar uma cidade saudável, conceito que ainda difere da promoção da saúde preconizada por CERQUEIRA (1997):

"... eu acho que é essa reunião da comunidade e dos poderes públicos, essa união de todos e que desperta o interesse maior eu acho que aquele amor maior pela cidade." (IVPL).

Conforme já apresentamos no referencial teórico (capítulo 2) , a OMS definiu dez requisitos para a cidade saudável. Os moradores de Bertioga, participantes do projeto durante as oficinas embora não tendo memorizado estes requisitos foram apontando problemas e sonhos que perpassaram praticamente estes dez pontos:

A necessidade de melhorar o ambiente físico para que ele se torne limpo e seguro foi assinalada. Problemas relacionados ao saneamento básico, o destino inadequado do lixo, que suja as praias e a cidade e as favelas que significam falta de qualidade das habitações são aspectos a serem trabalhados. 
As ameaças ao ecossistema pela poluição do oceano, rios, destruição dos mangues e da mata atlântica pelas invasões de terras pode ser reconhecido como outro requisito não cumprido que necessita de investimento.

Grande parte da população de Bertioga não tem suas necessidades básicas satisfeitas: falta trabalho e renda, educação de qualidade para todas as crianças, até o segundo grau e acesso aos serviços de saúde para a população de todos os bairros.

Ainda e economia local não é diversificada e criativa. Está baseada na construção civil, e na oferta de serviços especialmente ligados à área do turismo. Essa economia apresenta-se frágil por não ser diversificada e ser dependente do fluxo de turistas em alguns períodos do ano.

Há uma preocupação de preservação dos monumentos históricos e da cultura local, mas não existe efetivamente uma política e uma estratégia de ação que contemple esses aspectos. Aliado a esse fator, a população migrante nem conhece e respeita a herança cultural da cidade e muito menos partilha dela.

Um plano de ação para um Projeto Municípios Saudáveis tem muito em que pensar e necessita de um trabalho organizado do governo com ajuda da população. Um requisito que podemos dizer que avançou neste primeiro anos de atividades foi o alto grau de participação social, muito pelo efeito da utilização das metodologias participativas.

Os resultados apresentados no capítulo 7 demonstram que houve participação de moradores de todas as regiões de Bertioga, de todas as classes e segmentos sociais. Até mesmo representantes das camadas populares, os mais carentes, fizeram-se presentes, indicando que é possivel 
iniciar-se um processo de mobilização mais autônoma, mesmo numa situação de carência.

Apesar de que muitos dos itens tenham tido uma avaliação "negativa", esse estado de arte apenas reflete uma percepção, um sentimento do momento em que esse período foi analisado. Essas percepções mudam de acordo com a mudança das políticas públicas, variação dos indicadores sociais e nível de participação de todos os setores da sociedade.

Mesmo que a solução dos problemas apontados não tenha sido encaminhada, houve uma tomada de consciência sobre a situação sócioeconômica ambiental em relação ao município.

O município saudável é apenas um sonho, como uma estrela a guiar os passos de um viajante. Os caminhos são vários, mas para se iniciar a caminhada é preciso dar os primeiros passos. Julgamos que foram dados.

O efeito das metodologias participativas no protagonismo dos atores sociais de Bertioga

Foi possivel identificar vários efeitos das metodologias participativas para os participantes. Um deles, por exemplo, foi o de que algumas técnicas foram incorporadas no dia-a-dia profissional desta professora:

... porque na área onde eu atuo que é a educação você aproveita, eu aproveitei algumas dinâmicas que vocês fizeram de sensibilização passei para os meus alunos, chama atenção desde, porque antes de eu falar o que eu penso eu sempre pergunto o que eles pensam. (RGB).

A metodologia adotada permitiu, também, uma mudança no discurso e na ampliação da consciência de alguns problemas, como pode ser percebido na fala desta participante. Essa mudança de discurso, é a que se refere SADER no seu conceito de matriz discursiva (1988 p. 60) : 
... eu percebia que quando chegava no meio, as pessoas, no meio dos encontros, as pessoas já começavam a falar diferente, eles já começavam a falar assim Ah pera aí um pouquinho mas não é bem assim, não é por isso, pode ser por outra coisa, então já começa a trabalhar a consciência das pessoas do que exatamente tinha de problema na cidade e iam mudando os discursos eu achei muito interessante esse trabalho. (MLSM).

A metodologia tocou a sensibilidade de muitos participantes. Os dados que apresentaremos a seguir demonstram este efeito.

Um dos participantes do grupo de Riviera (LF) escreveu um poema que foi apresentado na quarta oficina desse grupo que sintetiza sua percepção e seus sentimentos sobre o projeto:

\author{
Foi um convite de ouvido \\ Para nós reunião \\ Estamos lá \\ Um forró sem pretensão \\ $\mathrm{Na}$ escolinha da Riviera \\ A verdade foi outra \\ Nada de bagunça \\ Tratava-se de integrar num trabalho de pesquisa \\ Município saudável, Projeto Bertioga se chamava \\ Turma boa de execução \\ Todos da USP que são \\ Segunda feira é o seu dia \\ Reuniōes de entrosamento \\ Sem cerveja, sem musiquinha \\ Mas sobrava ensinamento \\ Falas mansas, mas profundas \\ Deixava a todos a impressão \\ Que não ia dar em nada \\ Logrados fomos sem exceção \\ Continuamos na segunda-feira \\ Aprofundados nos sonhos \\ Modelitos, técnicas de jogos \\ Deixando a todos envolvidos \\ $E$ forró nem sombra \\ Convencer em profusão \\ Dai-lhe quadro negro com \\ Enorme provação \\ E foi assim \\ Que o primeiro e o terceiro \\ Era segunda-feira \\ Segunda feira \\ As oito das novidades \\ A redaçăo, as parcerias \\ Já estamos juntos segundas \\ Os conhecimentos são de primeira \\ Mas tirando o bom falatório \\ Nos sobrou a brincadeira \\ Foi então a melhor
}


Todo mundo aderiu com a diversão

Orelha com orelha

Cotovelo, calcanhar, saravá

Só o que faltava foi o rabo de ação

Então veja a reunião

Eu, uma pessoa legal

Foi só sentar um pouquinho

$E$ dai lhe a reunião danada

Quase acabou em forró

Ensinaram coisas novas

Para o modelo chegar logo

Ao mesmo prazo almejado

Estamos nos aproximando

De um certeiro e bom final

Aguardando uns aos outros

Colaborando com o essencial

Hoje sinto a falta de todos querendo mais

O que será de todos nós sem a segunda-feira

O que se faz?

A vocès todos

Queremos aproveitar

$O$ amor que desejamos que seja eficaz

Até a próxima segunda-feira

Deixando a terça, quarta, a quinta, a sexta

Sejam dias tão alegres

Sejam dias como a segunda que já foi boa

Uma outra participante do grupo de Riviera (MGSM) compôs uma letra com música que foi apresentado no I Seminário do Projeto Bertioga Municipio Saudável:
Município Saudável
Não é sonho isso pode acontecer,
Com a força e garra
Todos unidos faremos acontecer
Não queremos a falta de união,
Não queremos a falta de ação
Vamos todos lutar com devoção
E o municipio saudável
Construiremos com a nossa união

\section{Objetivos das Oficinas do Futuro}

No tocante aos objetivos das Oficinas do Futuro, pudemos concluir que foram parcialmente atingidos em muitos pontos, mas em relação ao 
fortalecimento da participação comunitária uma das estratégias do municipio saudável, o resultado foi positivo.

Houve um fortalecimento no sentimento de pertencimento com relação à Bertioga:

"Bertioga é linda!" (Morador de Rio da Praia).

"É boa!" (Morador de Delphino).

“... eu sou nordestino, mas Bertioga é um lugar 'bom', 'hospitaleira"' (Morador de Rio da Praia).

Ocorreu também, por parte dos participantes, uma maior compreensão das condiçōes sócio-ambientais locais como identificar a causalidade primeira dos problemas, evidenciada pelas falas gravadas durante a exaustiva troca de informações que ocorreu durante as oficinas realizadas pelo projeto, como é possivel ver a seguir:

“... ela veio enriquecer um pouco mais o conhecimento que a gente já tinha e a vontade que a gente tem de ver Bertioga melhorar." (IVPL).

As propostas e demandas foram levantadas e sistematizadas, resultando na elaboração das agendas de prioridades por região, as quais foram apresentadas durante o I Seminário Municipal do Projeto Bertioga Municipio Saudável.

Quanto à capacitação de lideranças para o exercicio de atividades para o desenvolvimento do Projeto Bertioga Município Saudável na região, não foi possivel a sua verificação.

Pôde-se ainda verificar que os grupos, para a apresentação das agendas no seminário anteriormente citado, foram constituídos, mas a sua posterior continuidade deveria ser fruto de outro estudo. 


\section{A formação da rede de apoio ao Projeto Bertioga Municipio}

\section{Saudável}

Finalmente, quanto ao surgimento de redes de apoio ao Projeto Bertioga Município Saudável, é possível se constatar alguns fatos.

Houve a participação de moradores de praticamente todas as regiōes de Bertioga, e no aspecto da sensibilização em relação ao desejo de busca de um município saudável há um relativo consenso entre todos os participantes, apesar de ainda não haver uma única matriz discursiva (SADER, 1988), do que seja exatamente esse municipio saudável ou mesmo das estratégias de ação para se atingir esse objetivo.

As oficinas possibilitaram a troca de informaçōes, gerando novos espaços de interlocução no interior da sociedade civil.

\footnotetext{
... as pessoas não tinham esta oportunidade de se encontrar para discutir os problemas da cidade, porque no começo inclusive as pessoas não sabiam detectar os problemas, e falavam, falavam, reclamavam de uma série de coisas mas náo tinham muita consciência do que exatamente podiam fazer (MLSM)
}

A formação da Comissão Intersetorial, no início de 2001, pode ser vista como o início da formação de uma rede municipal de apoio ao Projeto Bertioga Município Saudável, já que moradores de quatro áreas ( $A, B, C$ e D) fazem parte de sua constituição. Essa rede visa a ajudar no gerenciamento da proposta Cidade Saudável em Bertioga, em uma relação politica mais horizontalizada, que aproxima o poder público da sociedade civil e o local do municipal (SCHERER-WARREN, 1999, p. 28). O ideal comum que aparentemente une esse grupo é o desejo de implementação do sonho de uma Bertioga saudável.

Essa rede constitui-se em um contraponto à fragmentação percebida pelos moradores, uma possibilidade de interferir nas politicas públicas dentro 
de uma concepção de participação preconizada por VALLA (1993), RUIZ (1998) e MELUCCI (1989), citado por SCHERER-WARREN (1999, p. 26).

Algumas fragilidades podem ser detectadas no caminho do fortalecimento e desenvolvimento dessas redes:

- A mudança dos gestores das políticas públicas afeta a continuidade na participação e na interface de diálogo com a sociedade civil. Para a consolidação de uma rede, é necessário um tempo histórico. A mudança na composição da comissão é praticamente total com relação aos membros representantes do poder público.

- A representatividade dos membros da sociedade civil é um fator que deve ser considerado, para que ações locais possam ser estimuladas e as prioridades estabelecidas pelos grupos, em cada área, possam ser atendidas. Aos membros da comissão intersetorial cabe um importante papel no fortalecimento e multiplicação dessas redes e sua representatividade garante uma maior possibilidade para a sensibilização e mobilização de mais indivíduos e setores da sociedade civil.

- A ausência de uma área $(V)$ indica uma dificuldade quanto à participação dessa região na articulação dessa rede. Essa dificuldade pode ser ocasionada por uma falta de comunicação, extensão do município, desmobilização, falta de motivação e outros fatores. A fragilidade na articulação da rede constitui-se em um nó crítico para sua expansão e fortalecimento.

As fragilidades mencionadas, especialmente as duas primeiras, demonstram que ainda não se mostra segura a possibilidade de uma 
participação maior da sociedade civil de Bertioga na formulação, execução, fiscalização e avaliação das políticas públicas na área social. Por outro lado, fica evidenciado um forte processo de sensibilização em uma parcela significativa da população quanto à proposta do Projeto Bertioga Município Saudável.

Quanto à identificação dos problemas e sua causalidade, foi efetuada uma análise de algumas cadeias causais relacionadas a alguns problemas, faltando a delimitação de seu espaço físico e a identificação de seus nós criticos. As Oficinas do Futuro, como técnica, com a duração de tempo que foi concebida não permitiu que todos esses aspectos fossem trabalhados. De qualquer forma, foi possivel perceber a complexidade na discussão da causalidade dos diversos problemas.

As metodologias participativas tiveram influência e contaram com a receptividade da população, mas não foi possível verificar sua influência no protagonismo dos atores sociais, isto é, a negociação de poder e a tomada de decisão compartilhada entre cidadãos e autoridades, pois esta questão depende de fatores externos.

Finalizando, este primeiro ano de atividades cumpriu pelo menos uma das três fases de um Projeto Município Saudável, definidas pela Organização Mundial de saúde - escritório Europeu (WHO, 1997) e iniciou a Segunda que se refere ao aspecto organizacional.

Segundo o documento da OMS, um projeto realmente se inicia, quando mais de um ator da cidade compreende que a mesma se beneficiará utilizando uma nova abordagem de saúde, que oriente as ações para um processo de desenvolvimento de municipio saudável. Envolve compreensão e aceitação das idéias que orientem esse processo, convertendo-o em propostas práticas, que contribuam para a resolução dos problemas da vida 
na cidade e capazes de serem adotadas politicamente pelo governo municipal, junto com a população (WHO 1997 p. 19-26).

A formação do Conselho ou Comissão intersetorial, marca o começo formal do Projeto e inicia a fase de organização. O Seminário Municipal realizado ao final do primeiro ano cumpriu este requisito.

A seguir serão feitas as considerações finais desta dissertação. 


\section{Considerações Finais}


Esta monografia se propôs a analisar a participação da sociedade civil na formulação e implantação do Projeto Bertioga Município Saudável, por intermédio do apoio inicial da Faculdade de Saúde Pública. Tentaremos colocar aqui fazer considerações gerais, a partir dos objetivos da dissertação.

Para realizar tal intenção, foi necessário caracterizar o tecido social de Bertioga, isto é, identificar os diversos atores sociais, grupos / organizações / instituições, seus interesses, necessidades e sonhos, em relação ao município.

Partimos da conceituação de participação social como o conjunto de "múltiplas ações para poder influenciar a formulação, execução, fiscalização e avaliação das políticas públicas na área social" (VALLA 1993 p. 13).

A Pesquisa Exploratória, as oficinas de sensibilização e as Oficinas do Futuro tiveram o papel de descoberta da realidade para os pesquisadores e, por outro lado, também para a população.

A Pesquisa exploratória permitiu caracterizar o tecido social de Bertioga, os movimentos sociais, grupos, organizações e instituições e as iniciativas nas quais estes estão envolvidos.

Uma análise combinada da tabela 2 e 4, das Oficinas Regionais e das Oficinas do Futuro nos permitiram fazer as seguintes considerações sobre a composição do tecido social de Bertioga.

Em Bertioga não foi identificado nenhum movimento social organizado e forte que objetiva a transformação da cidade. Há vários partidos políticos, muitos deles sem ideologia definida. Os líderes envolvidos nessa forma de 
participação tradicional foram identificados e puderam expressar seus posicionamentos às necessidades e sonhos do municipio.

As associações e sindicatos classistas de segmentos da sociedade, outra forma tradicional de participação têm uma representatividade importante na sociedade local. As diferentes associações e sindicatos são organizados e têm uma efetiva participação nos momentos importantes na tomada de decisões.

As sociedades de amigos de bairro e associações de moradores são as iniciativas que envolvem numericamente maior número de pessoas, mas a sua organização é frágil. Nas Oficinas do Futuro, os participantes ligados à essas associações traziam somente percepções e opiniões muito individuais, o que pode ser um indicativo pressupor que essas associaçōes não são identidades coletivas, autônomas, independentes de pessoas que partilham objetivos e ideais comuns.

Muitos ideais de lutas, de instituições filantrópicas e centros comunitários, mencionados pelos participantes podem ser consideradas de caráter assistencialista, indicando um alto grau de paternalismo que interfere negativamente em processos de construção de cidadania como é o de municipio saudável.

Foi possivel identificar os principais problemas que afligem a população. Conforme resultados apresentados no capitulo 7 os principais problemas de Bertioga são a falta de saneamento básico, a saúde pública, a falta de limpeza e a falta de segurança. Esses problemas são diferenciados conforme a área dentro do município. Essa diferenciação se dá, também, com relação às lutas e às atividades movidas pelas organizações, bem como pelo perfil sociocultural. 
Nas áreas mais distantes do centro, com exceção de Riviera, as áreas $C$ e $E$, surgiram preocupações diferenciadas dos moradores das regiōes $A e$ $B$ que, por sua vez, foram diferentes das da região $C$.

Algumas suposiçōes poderiam ser cogitadas como, por exemplo, a relação entre as áreas, suas organizações e suas lutas, seus problemas e suas necessidades.

Os principais aspectos positivos, segundo uma parcela dos moradores de Bertioga são as praias e o potencial turístico.

Quanto aos sonhos dos moradores de Bertioga, o principal deles é a mudança da administração pública.

A metodologia demonstrou ser adequada para a identificação e caracterização do tecido social de Bertioga, ou seja, permitiu identificar os diversos atores sociais, movimentos sociais e grupos/organizações/instituições, seus interesses, necessidades e sonhos em relação ao município de Bertioga. $O$ uso combinado de metodologias qualitativas mais estruturadas como a que foi utilizada no levantamento de lideranças e outras metodologias como as oficinas de sensibilização e do futuro permitem identificar em um primeiro momento as lideranças e suas lutas e aprofundar posteriormente este conhecimento.

Por outro lado, por meio desta abordagem participativa, foi possivel a sensibilização de uma parcela significativa da população e o envolvimento de alguns indivíduos no início da formação de uma rede de apoio ao Projeto Bertioga Municipio Saudável. A continuidade do projeto, mesmo com as mudanças políticas após o processo eleitoral, comprovou esse envolvimento conforme capitulo 6 . 
Não foi possivel verificar o efeito das metodologias participativas utilizadas, no estímulo ao protagonismo (RUIZ 1998, WESTPHAL 1997) dos diversos grupos sociais de Bertioga, devido ao projeto ainda estar em uma fase de pré-implementação e às mudanças no quadro político-administrativo.

Concluindo, este primeiro ano de atividades mostrou-se como um momento inicial de sensibilização e de conhecimento da proposta de municípios saudáveis, e do início da formação de uma rede de apoio e sustentação para a Comissão intersetorial que representa uma forma inicial de organização do Projeto Bertioga Município Saudável.

Para a verificação da continuidade deste processo, seria fundamental a continuidade no acompanhamento e na análise desses processos nos anos subseqüentes. 


\section{REFERÊNCIAS BIBLIOGRÁFICAS}


ALMEIDA, Eurivaldo Sampaio de. Cidade/Município saudável - A questão estratégica: o compromisso político. SAÚDE E SOCIEDADE, São Paulo, Faculdade de Saúde Pública da Universidade de São Paulo, v..6, n. 2, p. 71-81, $2^{\circ}$ semestre, 1997.

AMMANN, Safira Bezerra. Participação Social. São Paulo, Cortez \& Moraes, 1978.

ASHTON, John. The origins of Healthy Cities. In: ASHTON, John (edit.) Healthy Cities, Open University Press, Philadelphia, 1992. p. 1-12.

BAENINGER, Rosana.; SOUZA, Marta Rovery. Migração em São Paulo 5. Região de Governo Santos. Textos NEPO, $\mathrm{n}^{\circ}$ 28, 1994.

BARBOSA, S. R. de C. S. Qualidade de Vida e Ambiente. Uma temática em construção. In: BARBOSA, Sônia Regina de Cal Seixas (org.) A temática Ambiental e a Pluraridade do Ciclo de Seminários do NEPAM. Campinas, Unicamp/NEPAM, 1998 (Textos NEPAM, Série Divulgação Acadêmica 4). p. 401-25.

BARBOSA, Sônia Regina da Cal Seixas. Ambiente, qualidade de vida e cidadania. Algumas reflexões sobre regiōes urbano-industriais. In: HOGAN, Daniel; VIEIRA, Paulo (orgs.). Dilemas Socioambientais e Desenvolvimento Sustentável. Campinas, Unicamp, p. 193-210, 1992.

BARROS, F. C. \& VICTORA C. G. Epidemiologia da Saúde Infantil. Um manual para diagnósticos comunitários. São Paulo, Hucitec, 1998.

BENEVIDES, Maria Vitória de Mesquita. A Cidadania Ativa. Referendo, Plebiscito e Iniciativa Popular. Editora Ática. São Paulo, 1991. p. 1-23.

BERG, Peter. Bioregional and Wild! A New Cultural Image. In: PLANT, Christopher; PLANT, Judith (eds.). Turtle Talk: Voices for a Sustainable Future. Lillooet: New Society Publishers, 1990. p. 21-30.

BÓGUS, Cláudia Maria - A Formação Política e o Fortalecimento da Participação Popular em Saúde: o caso dos Cursos de Formação Politica de Conselheiros de Saúde do Movimento de Saúde da Zona Leste de São Paulo. Tese de Doutorado, Faculdade de Saúde da USP, 1997.

BORDENAVE, Juan E. La transferencia de tecnología apropriada al pequeño agricultor. Revista Interamericana de Educação de Adultos, vol. 3, n. 1-2, 1980 (texto adaptado, sem autoria).

BOMFIN, Zulmira Áurea Cruz. A mediação emocional no desvelar da identidade em psicologia comunitária. In: BRANDÃO, Israel Rocha; BOMFIM, Zulmira Aurea Cruz (orgs.). Os Jardins da Psicologia Comunitária. Fortaleza, Pró-Reitoria da Universidade Federal do Ceará, 1999. p. 99-110.

BRASIL. Leis, etc. $n^{\circ} 8080$, de 19 de setembro: dispõe sobre as condições para a promoção, proteção e recuperação da saúde, a organização e o funcionamento dos serviços 
correspondentes e dá outras provid6encias. Diário oficial da União, - Sec. I, Brasília, 19 set. 1990. p.18055-9.

BUARQUE, Sérgio C. Metodologia de Planejamento do Desenvolvimento Local e Municipal Sustentável. IICA. p. 69-106, 1997.

CERQUEIRA, María T. - Promoción de la salud y educación para la salud: Retos y perspectivas. In: La Promoción de la Salud y La Educación para la Salud en América Latina: un Análisis Sectorial. OPAS, p. 7-24, 1997

CONTONGS, Caroline, SPRINGETT, Jane. Towards a Framework for the Evaluation of Health-related Policies in Cities. Evaluation. SAGE Publications. London. Vol3(3): 345-362, 1997.

CORDEIRO, Hésio. A qualidade de Vida Urbana e as Condições de Saúde: o caso do Rio de Janeiro. In: SOUZA, Amaury (org.). Qualidade de vida urbana. Série Debates Urbanos. Rio de Janeiro: Zahar, 1984.

CRELIER, Vânia. Projeção para o Futuro. In: MONTEIRO, Regina (Org) Técnicas Fundamentais do Psicodrama. São Paulo, Brasiliense, 1993. p. 85-91.

CROCKER, David. Qualidade de vida e desenvolvimento: o enfoque normativo de Sen e Nussbaum. CEDEC, Qualidade de vida. LUA NOVA. Revista de Cultura e Politica, n. 31, p. 99-134, 1993.

DALLARI, Dalmo. Direito de participação. In.: SORRENTINO, Marcos. Ambientalismo e participação na contemporaneidade. São Paulo, Educ, 2001.

DAWBOR, Ladislau. Globalização e tendências institucionais. In: DOWBOR, L. et alii. Desafios da Globalização. São Paulo, Vozes, 1998. p. 7-16.

DEL RIO, Vicente. Cidade da Mente, Cidade Real. Percepção Ambiental e Revitalização na área Portuária do RJ. In: DEL RIO, Vicente. OLIVEIRA, Lívia de (Org.). Percepção Ambiental. A experiência Brasileira. Studio Nobel, 1991. p. 3-22.

DEMO, Pedro. Participação e avaliação. UCLA. TTexto apresentado para o Ciclo de Seminários "Ambientalismo e Participação na Contemporaneidade". São Paulo], 2000].

DEMO, Pedro. Participação é conquista. São Paulo, Cortez, 1988.

DURKHEIN, E. As regras do método sociológico. $3^{\circ}$ edição. São Paulo. Editora Nacional, 1963

FERRAZ, Sônia Terra. A Pertinência da Adoção da Filosofia de Cidades Saudáveis no Brasil. Saúde em Debate, n. 41, p. 45-9, 1993.

FERREIRA, Leila da Costa. A Questão Ambiental. Sustentabilidade $e$ politicas públicas no Brasil. S/I., Boitempo Editorial, 1998. p. 13-63.

FERREIRA, Lúcia da Costa. Conflitos Sociais. Texto de apoio. Campinas . NEPAM, Unicamp/PADCT, CIAMB,1998. 
FEUERSTEIN, Marie-Thérèse. Partners in Evaluation. Evaluating Development and Community Programmes With Participants. Macmillan Publishers/ TALC Teaching aids at low cost. London, 1986.

GOHN, M. G. Teoria dos movimentos sociais: paradigmas clássicos e contemporâneos. São Paulo, Loyola, 1997.

GRANJA, Elza Corrêa. Diretrizes para a elaboração de dissertação e teses. São Paulo, USP, 1998. Mimeo.

GUDYNAS, Eduardo. NGOs facing democracy and globalization: the challenges in Latin America. Transnacional Associations, Bruxelas, 1997. p. 199-204.

HABERMAS, Jürgen. New Social Movements. S/., s/ed., 1981.

HAGUETTE, Teresa Maria Frota Haguette. Metodologias Qualitativas na Sociologia. Vozes, p. 58-68, 1987.

HERRERO, L. M. Jiménez. Desarrollo Sostenible y Economia Ecológica. S/l., sled.,1997.

HERZLICH, C. Health and IIIness - a social psychological analysis. London, Academic Presss, 1973.

IBGE - INSTITUTO BRASILEIRO DE GEOGRAFIA E ESTATÍSTICA Anuário estatistico. 1991.

IBGE - INSTITUTO BRASILEIRO DE GEOGRAFIA E ESTATISTICA Censo 2000. 2000.

IBGE - INSTITUTO BRASILEIRO DE GEOGRAFIA E ESTATÍSTICA Censo demográfico. 1996.

JACOBI, Pedro. Atores Sociais e Estado. Revista Espaço e Debates, n. 26, p. 10-21, 1989.

JACOBI, Pedro. Movimentos sociais e políticas públicas: demandas por saneamento básico e saúde: São Paulo 1974-84. São Paulo, Cortez, 1997.

JACOBI, p. R. \& NUNES, E. Movimentos populares urbanos, poder local e conquista da democracia. In: MOISÉS, J. A. Cidade, povo e poder. $2^{\circ}$ ed. Rio de Janeiro, Paz e Terra, 1985.

JODELET, D. La representación social: fenómenos, concepto y teoria. In: MOSCOVICl, S - Psicologia social, II -Pensamiento y vida; Psicologia social y problemas sociales. Buenos Aires, PAIDOS,.1986. p. 469-493 cap. 13.

KRAPPITZ, Uwe ET AL. Enfoque participativo para o trabalho em grupos. Conceitos básicos e um estudo de caso. S/I.,Fundação Friedrich Naumann, 1987.

MALIK, Ana Maria. Cidades saudáveis. Estratégia em aberto. In: SAÚDE E SOCIEDADE, São Paulo, Faculdade de Saúde Pública da Universidade de São Paulo, v..6 n. 2, $2^{\circ}$ semestre, p. 19-30, 1997. 
MENDES EV, TEIXEIRA CF, ARAÚJO EC, CARDOSO MRL. Distritos sanitários: conceito-chave. In: Mendes EV. Distrito Sanitário: o processo social de mudança das práticas sanitárias do Sistema Único de Saúde. São Paulo/ Rio de Janeiro: Hucitec/Abrasco, 1993.

MENDES, EV. Uma agenda para a saúde. São Paulo, Hucitec, 1996.

METTRICK, Hal. Development Oriented Research in Agriculture: an ICRA Textbook. ICRA. Wageningen. The Netherlands, 1993.

MINISTÉRIO DA SAÚDE. Promoção da Saúde. Carta de Ottawa. Declaração de Adelaide. Declaração de Sundswall. Declaração de Bogotá. Brasília, 1996.

MIR RC. Sistemas locales de salud: organización, regionalización, principios generales. In: Paganini JM, Mir RC editores. Los Sistemas Locales de Salud. Conceptos - Metodos - Experiências. Washington, D. C.: OPAS/OMS; 1990. (Pub. Cientifica N 519) p. 117-135.

NELSON, Nelson. WRIGHT, Susan. Participation and power. In: NELSON, Nici and WRIGHT, Susan. Power and Participatory Development. Theory and practice. London. Intermediate Technology Publications, 1995. p. 1-18.

NORMAS PARA PUBLICAÇÕES DA UNESP/ COORDENADORIA GERAL DE BIBLIOTECAS E EDITORA UNESP. Dissertações e Teses: do trabalho científico ao livro. São Paulo, Ed. Unesp, 1994 (Normas para Publicaçōes da Unesp).

OFFE, Claus. Partidos politicos y nuevos movimientos sociales. S/l., Editorial Sistema, 1994. p. 143-163.

ORGANIZAÇÃO MUNDIAL DE SAÚDE. Declaração de Jacarta. 1997.

PAHO. Pan American Health Organization. The healthy municipalities movement. A setting approach and strategy for health promotion in Latin America and the Caribe. (draft). Washington (DC); 1999.

PEREIRA, Percival Ribeiro. Município de Bertioga. Subdivisão Admnistrativa e Operacional. Proposta Básica Preliminar. Trabalho final para o I Curso de Multiplicadores para Assentamentos Humanos Saudáveis. Bertioga, 2001.

PIKE, Graham. SELBY, David. Educação Global. O Aprendizado Global. S/l., Texto Novo, 1999.

BERTIOGA. Plano Diretor de Desenvolvimento Sustentado de Bertiiga, Lei Municipal $n^{\circ} 315 / 98$.

PORTELLI, Hughes. Gramsci e o Bloco Histórico. Rio de Janeiro. São Paulo, Paz e Terra, 1972.

PREFEITURA MUNICIPAL DE SÃO PAULO. Agenda $X X I$ do Pedaço. Secretaria Municipal do Verde e Meio Ambiente. São Paulo, 1997. 
REDCLIFT, M. Sustainable Development: Concepts, Contradictions, and Conflicts. In: Allen, p. (Husg.): Food for the future. Conditions and Contradictions of Sustainability. New York, s/ed., 1993.

RIBEIRO, Roberto Teixeira. Diagnóstico de saúde de Município de Bertioga (SP). S/l., s/ed., 1999.

ROMAÑA, Maria Alicia. Construção Coletiva do Conhecimento através do Psicodrama. Campinas, Papirus, 1992.

ROMAÑA, Maria Alicia. Construção Coletiva do Conhecimento através do Psicodrama. Campinas. Papirus, 1992.

RUIZ, Gabriela. Análisis de la participación social en el Movimiento Municipios Saludables en América Latina. Tese de Mestrado da Facultẻ de Médicine/Université Laval. Laval, 1998.

SADER, Eder. Quando novos personagens entraram em cena; experiências e lutas dos trabalhadores da Grande São Paulo, 1970-1980. Rio de Janeiro, Paz e Terra, 1988.

SCHERER-WARREN, Ilse. Redes de Movimentos Sociais. Edições Loyola, 1996.

SEADE. Fundação Sistema Estadual de Análise de Dados. Informações dos Municipios Paulistas, 2000.

SEVERINO, Antonio Joaquim. Metodologia do Trabalho Científico. $20^{\mathrm{a}}$ ed. São Paulo: Cortez, 1996.

SOUZA SANTOS, Boaventura de. Pela Mão de Alice. O Social e o político na pós-modernidade. São Paulo, Cortez, 1995.

TASSARA, Eda T. de Oliveira. Intervenção Social e Conhecimento Cientifico: Questões de Método na Pesquisa Social Contemporânea. S/l., s/ed., 1996.

TASSARA, Eda T. de Oliveira; RABINOVICH, Elaine Pedreira. $A$ invenção do urbano e o poético: uma cartografia afetiva. In: TASSARA, Eda T. de Oliveira (org.) Panoramas interdisciplinares para uma psicologia ambiental do urbano. São Paulo, EDUC, 2001. p. 211-267.

THIOLLENT, Michel. Metodologia da Pesquisa-ação. São Paulo, Cortez, 1985.

TOURAINE, Alain . An Introduction to the Study of Social Movements. SOCIAL RESEARCH, vol. 52, n. 4, p. 749-787, 1985.

TOURAINE, Alain. Os novos conflitos sociais. Para evitar mal-entendidos. LUA NOVA. Revista de Cultura e politica, n. 17, p. 5-18, 1989.

TRATADO DE EDUCAÇĀO AMBIENTAL PARA SOCIEDADES SUSTENTÁVEIS E RESPONSABILIDADE GLOBAL. Fórum Internacional de Organizaçōes Não Governamentais e Movimentos Sociais. Rio-92, 1992. 
VALLA, Victor Vincent et al. Participação Popular e os serviços de Saúde: O Controle Social como Exercício da Cidadania. Rio de Janeiro. Fundação Oswaldo Cruz/ ENSp, 1993.

VIEZZER, Moema e OVALLES, O (orgs.) Manual Latino-Americano de EducAção Ambiental. Versão brasileira por Moema Viezzer e Raquel Trajber. São Paulo, Gaia, 1994.

WARD, V. M et alii. The Comparability of Focus Group and Survey Results. Three Case Studies. Evaluation Review, vol. 15, n. 2,p. 266-283, abril 1991.

WESTPHAL, M. F., BÓGUS, C. M. \& FARIA, M. de M. Grupos focais: experiências precursoras em programas educativos em saúde no Brasil. Boletín de la Oficina Sanitaria Panamericana 120, n. 6, p. 472-482, 1996.

WESTPHAL, Márcia Faria. A Defesa da Saúde nas Cidades. In Saúde na Cidade. VI Congresso Paulista de Saúde Pública. Mesa Redonda. Anais. Volume 2. Águas de Lindóia, 1999. p. 291-293.

WESTPHAL, Márcia Faria. Municipios Saudáveis: aspectos conceituais. SAÚDE E SOCIEDADE, São Paulo, Faculdade de Saúde Pública da Universidade de São Paulo, v.6, n. 2, p. 9-18, $2^{\circ}$ semestre, 1997.

WESTPHAL, Márcia Faria. Participação e Cidadania: aplicação à proposta de Promoção de saúde. São Paulo, 2000. Mimeo.

WESTPHAL, Márcia Faria - Participação popular e políticas municipais da saúde: o caso de Cotia e Vargem Grande. Tese de Livre-Docência Faculdade de Saúde da USP, 1992. p. 25-52.

WHO (World Health Organization/ Europe). Twenty steps for developing a Healthy Cities project. $3^{\circ}$ ed. 61 p. 1997 
ESTADO DE SÃO PAULO: LOCALIZAÇÃO DO MUNICÍPIO DE BERTIOGA

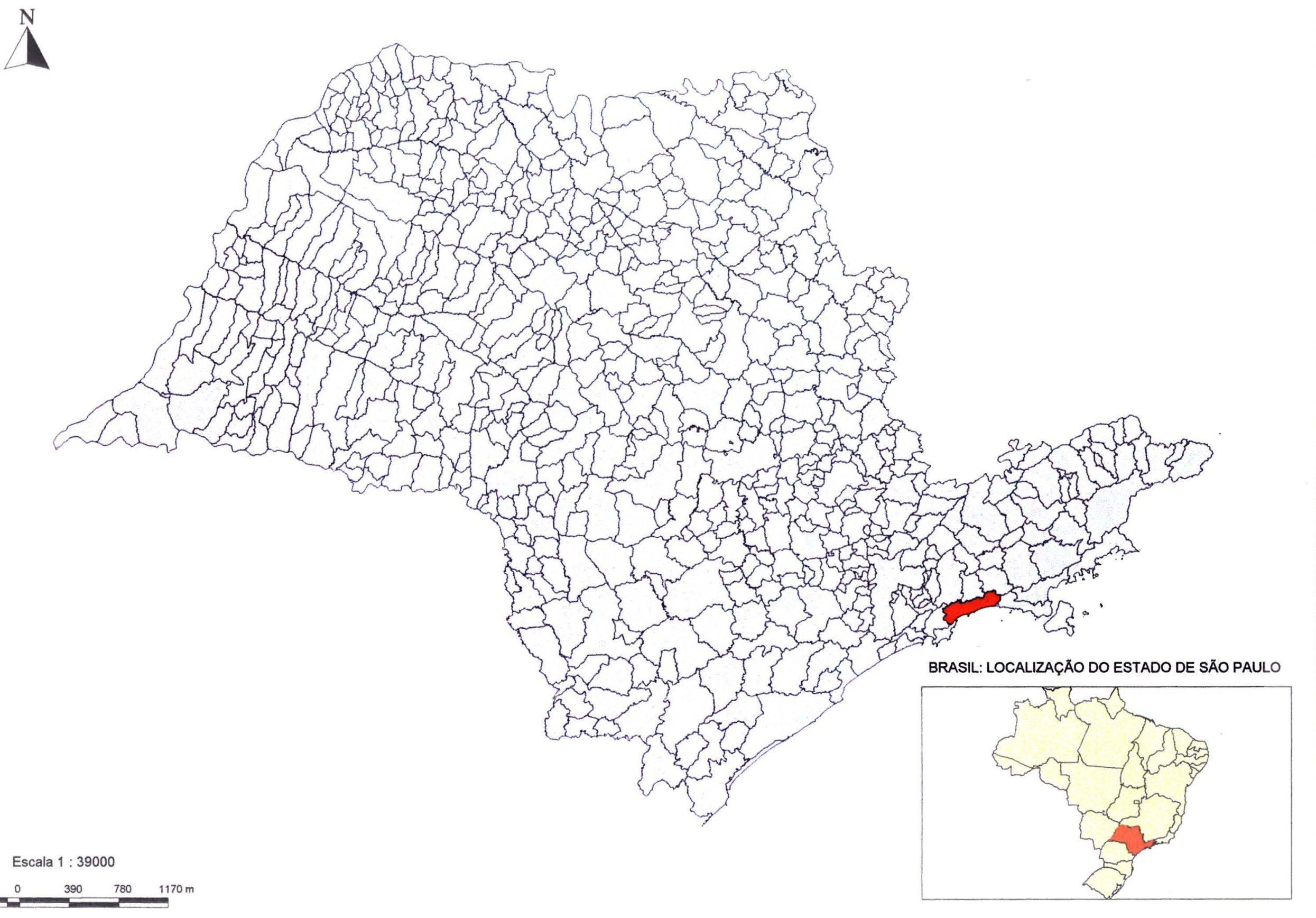

章 


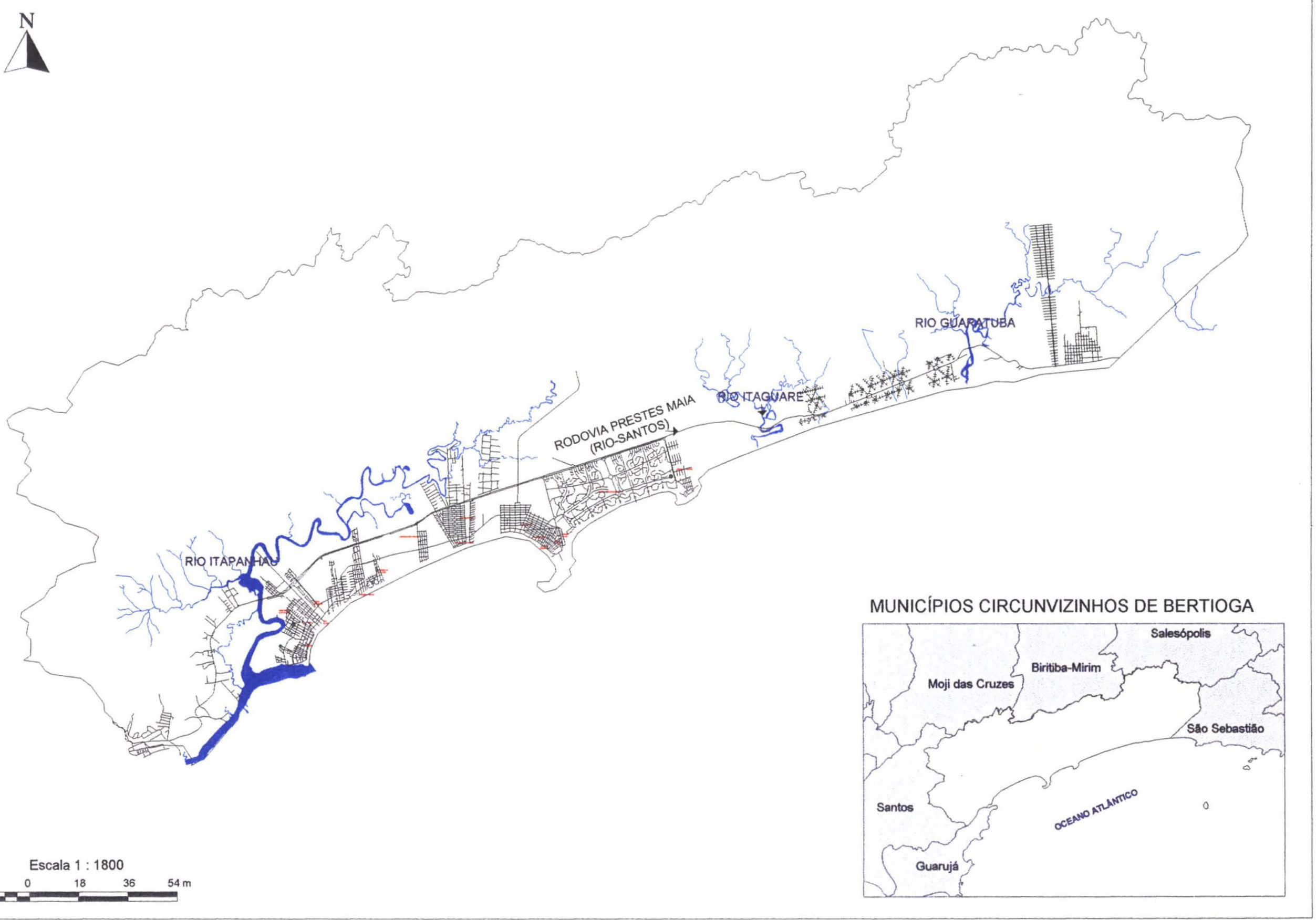

少 


\section{ANEXO 3}

Questionário para levantamento de lideranças, grupos, organizações, entidades e instituições

1. Dados do entrevistado

Nome do entrevistado

Em que vocé trabalha?

Endereço:

Bairro:

CEP

Fone

Fax

E-mail

Você participa de algum grupo ou movimento? Quais? Se não porque năo participa?

2. Dados da entidade (grupo/organização/entidadelinstituição) na qual você participa

Nome da entidade

Qual é a sua funçāo na entidade

Nome do Responsável pela entidade

Endereço da entidade:

Bairro:

CEP

Fone

Fax

E-mail

Caracterização (grupo/organização/entidade/instituição)

$\mathrm{N}^{\circ}$ de integrantes da entidade aproximado:

Quais'são as-tutas e trabalhos dá-entidade?

Qual é a frequência dos integrantes se reunirem:

Qual é a frequéncia das eleiçóes:

(As duas perguntas a seguir não são para perguntar)

Tipo:

口 Movimento popular

a Movimento ambientalista

a Movimento sindical

- Associação de moradores

- Entidade patronal

a Colegiado de entidades

- Entidade religiosa

a Outros. Especificar
Área de atuação/demanda:

$\square$ por moradia

$\square$ por infra-estrutura

- direitos políticos e civis

conquistas sindicais

כ saúde

geração de renda

$\square$ educaçăo

$\checkmark$ Outros. Especificar

Abrangência de atuação da entidade

D o(s) bairro(s) ou "pedaço"(s) Especificar:

일 municipio(s) Especificar:

Representatividade da entidade:

Participa de algum conselho, fórum ou consórcio? Especificar

Quais os principais parceiros de seu grupolorganizaçãolentidadelinstituição

1.

2. 
Contato:

tellend:

3.

Contato:

tellend:
Contato:

tellend:

4.

Contato:

tellend:

\section{Opinião do entrevistado:}

O que mais te incomoda no bairro/local? Cite três problemas:

1.

2.

3.

Dê duas sugestōes para resolver o primeiro problema:

1.

2.

Quais são os três aspectos mais positivos de Bertioga:

1.

2.

3.

Qual é o seu sonho para Bertioga?

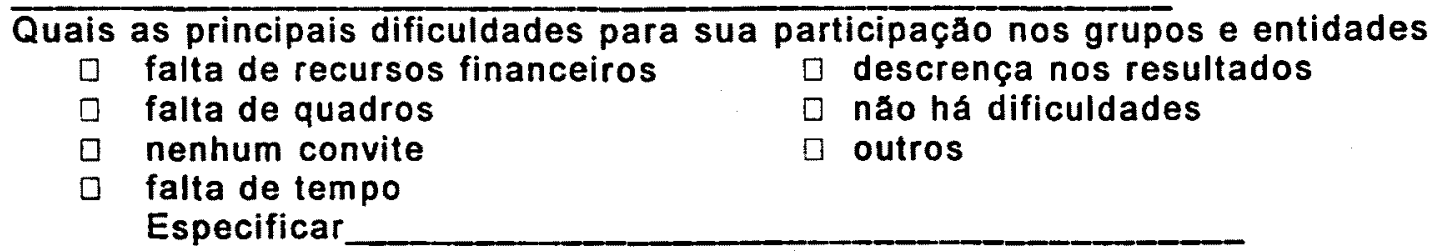

Quais pessoas ou grupos/organizaçōes/entidades/instituições você indicaria que deveriam participar do Projeto Bertioga Municlpio Saudável:

1. tel/end:

2. tel/end:

3. tellend:

Você gostaria de participar das oficinas regionais sobre o Projeto Bertioga Municipio Saudável? \im $\square$ Năo

Quais os melhores dias e horários para a realização da oficina?

Indique um local onde poderia ser realizada a oficina?

Você gostaria de ajudar na realização da oficina? Como você pode ajudar na realizaçăo da oficina?

Data:

Nome dos pesquisadores: 


\section{UNIVERSIDADE DE SÃO PAULO \\ FACULDADE DE SAÚDE PÚBLICA}

AV. DR ARNALDO. 715 - 01246-904 - SÃO PAULO - SP - TEL. (011) 853-2329 - FAX (011) 3066-7709

\section{TERMO DE CONSENTIMENTO LIVRE E ESCLARECIDO}

Pesquisa: "Levantamento preliminar do tecido social do municipio de Bertioga"

Responsável: Victor Jun Arai

Objetivo: Identificar lideranças comunitárias, grupos. instituições e entidades como possiveis parceiros do "Projeto Bertioga Municipio Saudável.

A pesquisa que estamos convidando o senhor (a) a participar ajudará a desenvolver a proposta Bertioga Municipio Saudável.

Este é um projeto que pretende envolver toda população da cidade na melhoria dos condições de vida no municipio. Suas respostas nos ajudarão a conhecer as pessoas que vivem aqui. as suas necessidades e outras pessoas que podem colaborar no projeto e suas necessidades.

Garantimos que as informações que nos der serão anotadas, mas mantidas em sigilo.

Prometemos que logo que terminarmos o trabalho vamos retormar para o senhor (a) os resultados da pesquisa.

Sua participação é livre e voluntária. sendo que. em qualquer momento da entrevista. o senhor (a) poderá desistir.

Sua participação também não implica em despesa por parte do senhor (a) e nem riscos para sua saúde e de sua familia.

Qualquer dúvida existente sobre o projeto será respondida pelos pesquisadores durante o decorrer do trabalho ou através do seguinte telefone:

Victor Jun Arai (0xx11) 3066-7766

Agradeço desde jả a colaboração de todos.

São Paulo. 31 de março de 2000.

Assinatura do pesquisador

RG

Endereço
Assinatura do entrevistado 


\section{ANEXO 5 \\ PROJETO BERTIOGA MUNICÍPIO SAUDÁVEL \\ O F I C I NAS RE G I O NA I S}

\begin{tabular}{|l|}
\hline 0. Ordem: \\
\hline 1. Nome: \\
\hline 2. Atividade: \\
\hline 3. Endereço Res. Rua: \\
\hline
\end{tabular}

4. Bairro

5 Cidade

6. CEP:

7. Fone: 0xx

8.-Fax: 0xx

9.- E-mail:

10. Participa de algum movimento?

SIM

NÃo

13. Nome da entidade:

14. Qual a sua função na entidade?

15. Nome do responsável:

16. Endereço da entidade:

17. Bairro: 18. CEP: 19. Cidade:

20. Fone:

21. Fax:

22. E-mail:

23. Número de integrantes:

24. Quais as lutas da entidade(cite as 3 principais)?

Bertioga, de de 2000 


\section{ANEXO 6 \\ Roteiro da $1^{\circ}$ Oficina de Sensibilizaçāo}

\section{MOMENTO 1}

Técnica de aquecimento:

Apresentação em duplas, utilizando-se técnica de entrevista onde foram abordados os seguintes questões que foram respondidas por cada participante: nome, expectativas em relação a oficina, conceitos de Promoção de Saúde e Municipio Saudável. (Anexo 2)

\section{MOMENTO' 2}

O momento 2 foi construído para apreender as diferentes opiniões/ percepções dos participantes sobre como é a cidade hoje e qual a utopia que eles possuem sobre a cidade. (como eles gostariam que ela fosse)

Técnica de aquecimento: divisão de grupos através de canções; Foram distribuídos trechos de algumas músicas conhecidas e os participantes agruparam-se de acordo com a igualdade das músicas

Trabalho em grupo respondendo duas questões através de técnica de desenho com lápis de cera.

a) Como é a minha cidade?

\section{MOMENTO 3}

Aspectos conceituais do municipio Saudável - Descentralização, Intersetorialidade, Participação Social, Avaliação, Sustentabilidade de projetos

Cinco relatos de moradores de Bertioga obtidos através de entrevistas foram entregues aos grupos. O grupo escolheu um relato e selecionou de um problema descrito. A tarefa do grupo foi levantar as causas desse problema e elaborar propostas de encaminhamentos para soluções, com enfoque na intersetorialidade e participação social

\section{4-AVALIAÇÃO}

- Como foi o dia de hoje?

- De tudo o que foi visto, o que você leva para casa?

- O que pode ser melhorado para amanhã? 


\section{ANEXO 7}

\section{Roteiro das Oficinas Regionais}

$1^{\circ}$ Momento - Apresentação da proposta de trabalho da Oficina;

$2^{\circ}$ Momento - Apresentação dos participantes e levantamento de expectativas;

$3^{\circ}$ Momento - Trabalhando os Conceitos de Promoção da Saúde/Município Saudável e Qualidade De Vida.

Trabalho em grupos respondendo à duas questões: como é Bertioga hoje e como gostaria que fosse;

$4^{\circ}$ Momento - Apresentação do histórico do Projeto Bertioga Municipio Saudável e os resultados da pesquisa exploratória'.

Neste momento apresentou-se os resultados da pesquisa exploratória destacando-se os problemas e os aspectos positivos mais citados pelos participantes;

$5^{\circ}$ Momento - Proposta de Continuidade

Neste momento anunciou-se uma proposta de continuidade através das oficinas do futuro e da realização do seminário municipal;

$6^{\circ}$ Momento - Avaliação da oficina

\footnotetext{
1 Pesquisa que foi realizada visando o levantamento de lideranças, os problemas, os sonhos e os aspectos positivos de Bertioga
} 


\section{ANEXO 8}

\section{SEGUNDA REUNIÃO: RAIZZES DOS PROBLEMAS}

Objetivos:

- Identificar as causas e a inter-relação entre as causas dos problemas

- Identificar os atores sociais envolvidos nos problemas

\section{Momento 1: Aquecimento}

Momento 2: Apresentação do programa e memória

\section{Momento 3: Determinação das causas dos problemas}

Se o problema já estiver bem definido usar a dinâmica de perguntar

o "porquê dos porquês" para ir aprofundando as "causas das causas" e fazer a ligação entre as causas. As seguintes questões são colocadas para trabalho em grupo ou individual:

Qual é o problema que vocês querem trabalhar? Como é o problema? Quais as causas desse problema?

Momento 4: Determinação dos atores envolvidos nos problemas Determinar atores que ajudam ou dificultam a resolução do problema através do uso de tarjetas respondendo a pergunta: Quem ajuda ou dificulta a resolver o problema?

Momento 5 : Avaliação do acordo de convivência

Momento 6 : Avaliação da reunião 


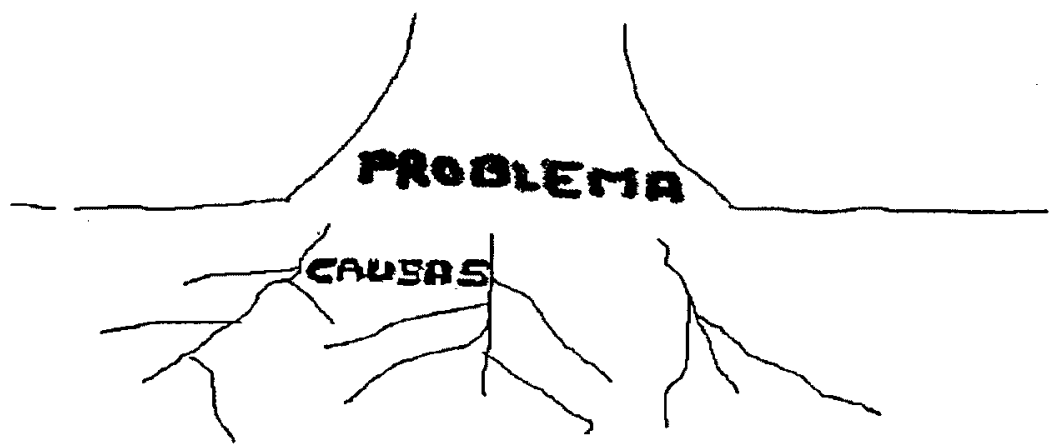

Problema definido e escolhido pelo grupo:

Problema 1

Causa 1

A

$\pi$

$\pi$ $\kappa$

Causa 3

Causa 2

$\uparrow$

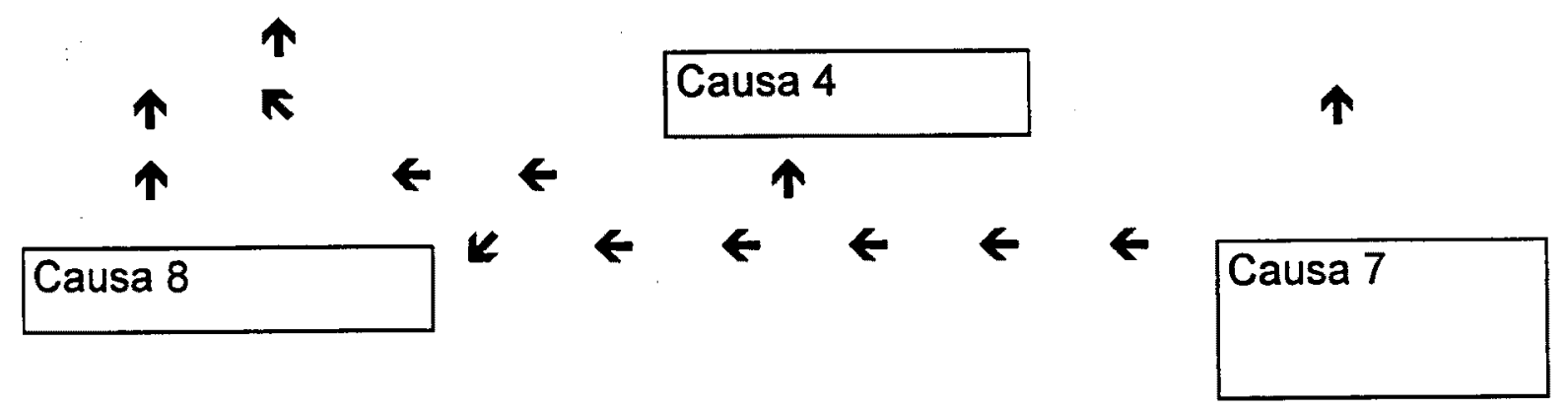




\section{ANEXO 9}

\section{TERCEIRA REUNIÃO: ATORES SOCIAIS}

\section{Objetivos:}

- Identificar atores sociais participantes da oficina ( seus grupos/ entidades/ instituiçōes)e suas iniciativas sociais

- Caracterizar as relações entre os atores sociais envolvidos nos problemas

Momento 1: Aquecimento

Técnica:

Tempo: 20 minutos

Momento 2: Apresentação da programação e memória da reunião anterior Tempo: 10 minutos

Momento 3: Quem somos e o que fazemos

Técnica: Trabalho em grupos

Questőes:

Nome do participante / grupo / entidade / instituição

Listar atividades sociais principais realizadas ou que pretende realizar

Tempo: 25 minutos

Momento 4: Plenária (Opcional: PBMS)

Tempo: 40 minutos

Intervalo

Tempo: 15 minutos

\section{Momento 5: Como nos relacionamos}

Técnica: Sociograma

Procedimento:

1. Determinar se cada participante representa uma instituição ou é um individuo? Se for individuo pega círculo verde, se for instituição pega círculo vermelho.

2. Definir se a sua influência é grande ou pequena para a resolução do problema. Se for grande pega círculo grande, se for pequena pega circulo pequeno. Definida a cor e o tamanho do círculo proceder da seguinte forma.

3. O problema está situado no centro de uma cartolina. O participante deve posicionar seu círculo com relação ao problema. Se já está ajudando em sua resolução ou pretende ajudar, posiciona-se perto do problema, senão ajuda, nem pretende colaborar posiciona-se afastado do problema.

4. Feito o posicionamento dos participantes presentes, então procede-se da mesma maneira que os itens 1,2 e 3 para os outros atores sociais que eståo envolvidos nos problemas, mesmo que estejam ausentes.

Momento 6: Plenária e sistematização

Tempo: 25 minutos

Momento 7: Avaliação do acordo

Tempo: 10 minutos

Momento 8: Avaliação da reunião

Tempo: 10 minutos 


\section{ANEXO 10}

\section{QUARTA REUNIÃO: AGENDA XXI DO PEDAÇO}

\section{Objetivos:}

- Estabelecer uma agenda de ações em busca de soluções para os problemas priorizados

- Definir estratégias para a continuidade do grupo

Momento 1: Aquecimento

Técnica: Pontos coloridos ou outra atividade (ou presentes)

Tempo: 20 minutos

Momento 2: Apresentação da programação e memória

Tempo: 10 minutos

Momento 3: O que é uma Agenda XXI do Pedaço

Técnica: Trabalho em grupos ou na plenária

O que é uma agenda para este grupo?

Quais itens devem estar anotados em uma agenda?

Quais atores sociais devem estar na agenda do grupo?

Qual é o pedaço do grupo?

Tempo: 30 minutos

Momento 4: Construção da Agenda XXI

Técnica: Trabalho em grupos

Questōes

Completar os itens da agenda

Tempo: 40 minutos

Momento 5: Plenária e sistematização

Tempo: 25 minutos

Intervalo

Tempo: 15 minutos

Momento 6: Discussão sobre continuidade do grupo

Técnica: discussão em grupo seguida de plenário

Questão

O que o grupo pode fazer antes e depois do seminário para permanecer como grupo?

OBS.: passar listas com endereços e telefones

Tempo: 20 minutos

Momento 7: Avaliação da reunião

Técnica: desenhos de rostos

Tempo: 20 minutos 


\section{ANEXO 11}

Roteiro de entrevista individual

Como você veio parar em Bertioga? Fale de sua relação com a cidade? Fale o que você conhece sobre o Projeto Bertioga Município Saudável? Como foi para você participar das oficinas e atividades do Projeto Bertioga Municipio Saudável? O que você mais aproveitou das oficinas e atividades do Projeto Bertioga Municipio Saudável? Em que sentido pessoal / profissional? Por que você acha que foi proveitoso ou que teve esse resultado? Você tentou ou está desenvolvendo alguma atividade que você acha que teve influência das oficinas e atividades do Projeto Bertioga Municipio Saudável?

Você ainda continua participando das atividades do Projeto Bertioga Município Saudável? Se parou, por que parou de participar? Hoje o que você entende por participação? O que você entende por cidade saudável? 
MUNICÍPIO DE BERTIOGA: MAPA DE LOCALIZAÇÃO DA ÁREA I (A)

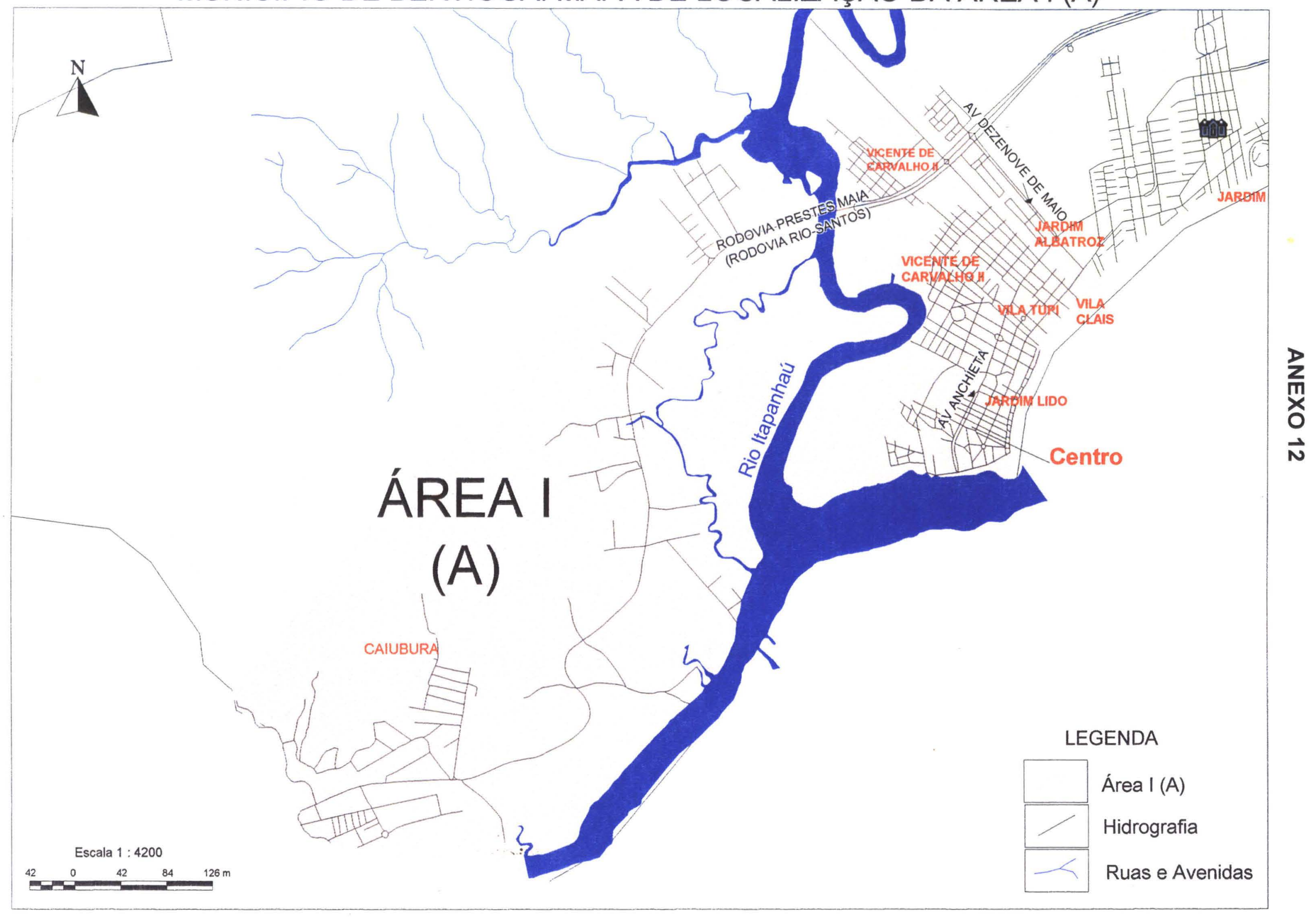


MUNICÍPIO DE BERTIOGA: MAPA DE LOCALIZAÇÃO DA ÁREA II (B)

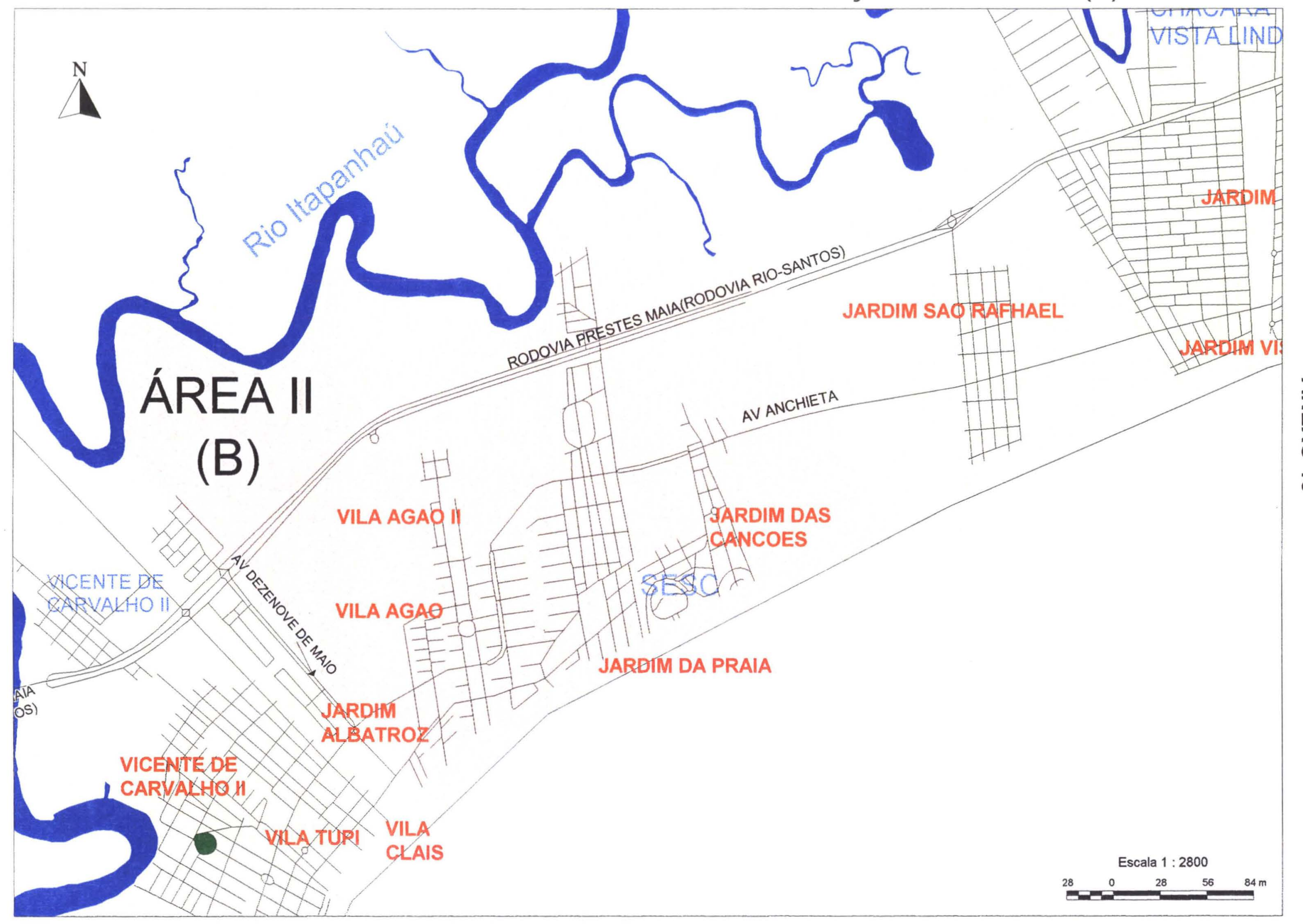

z
离
O
w 
MUNICÍPIO DE BERTIOGA: MAPA DE LOCALIZAC̣ÃO DA ÁREA III (C)

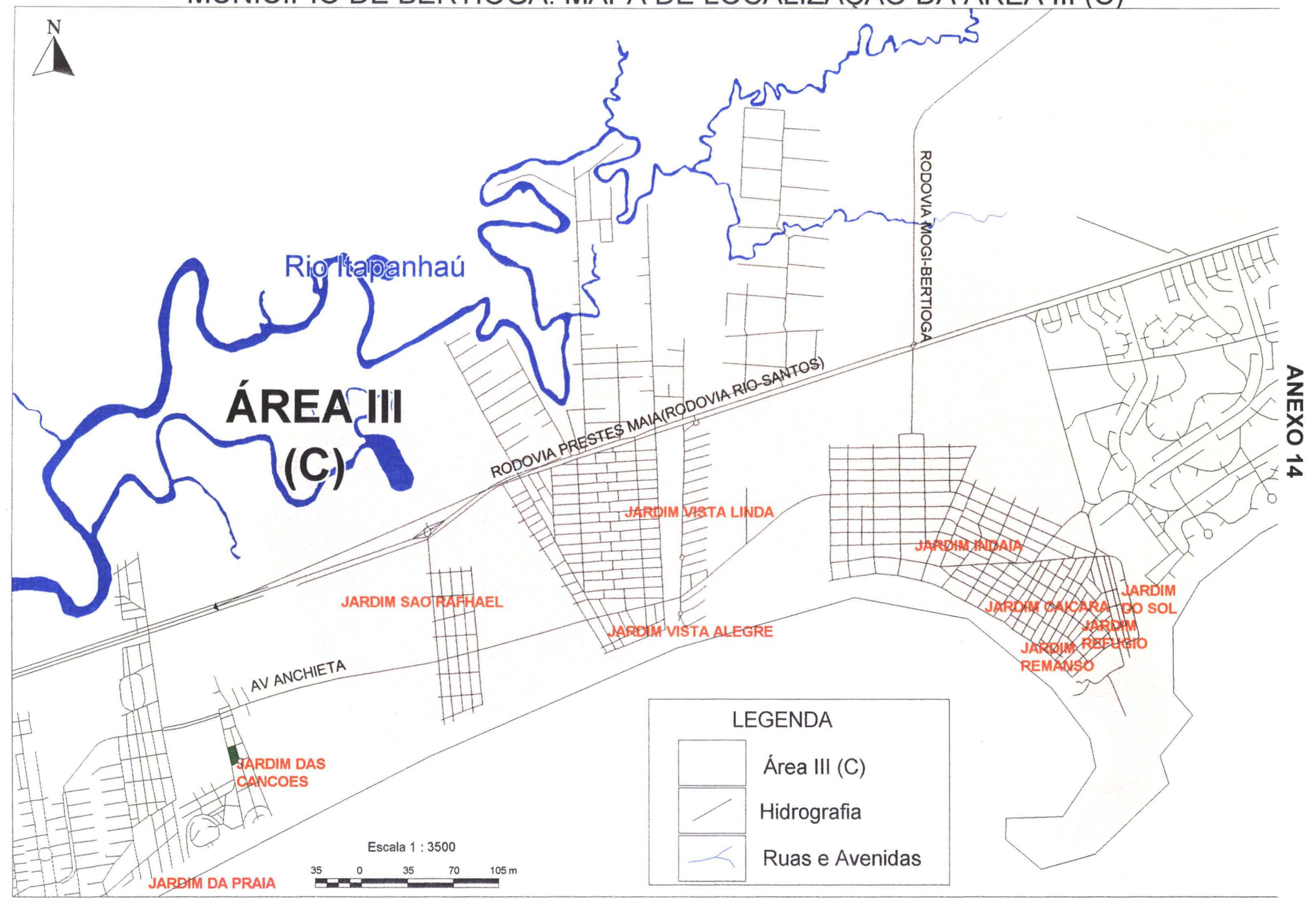


MUNICÍPIO DE BERTIOGA: MAPA DE LOCALIZAÇÃO DA ÁREA IV (D)

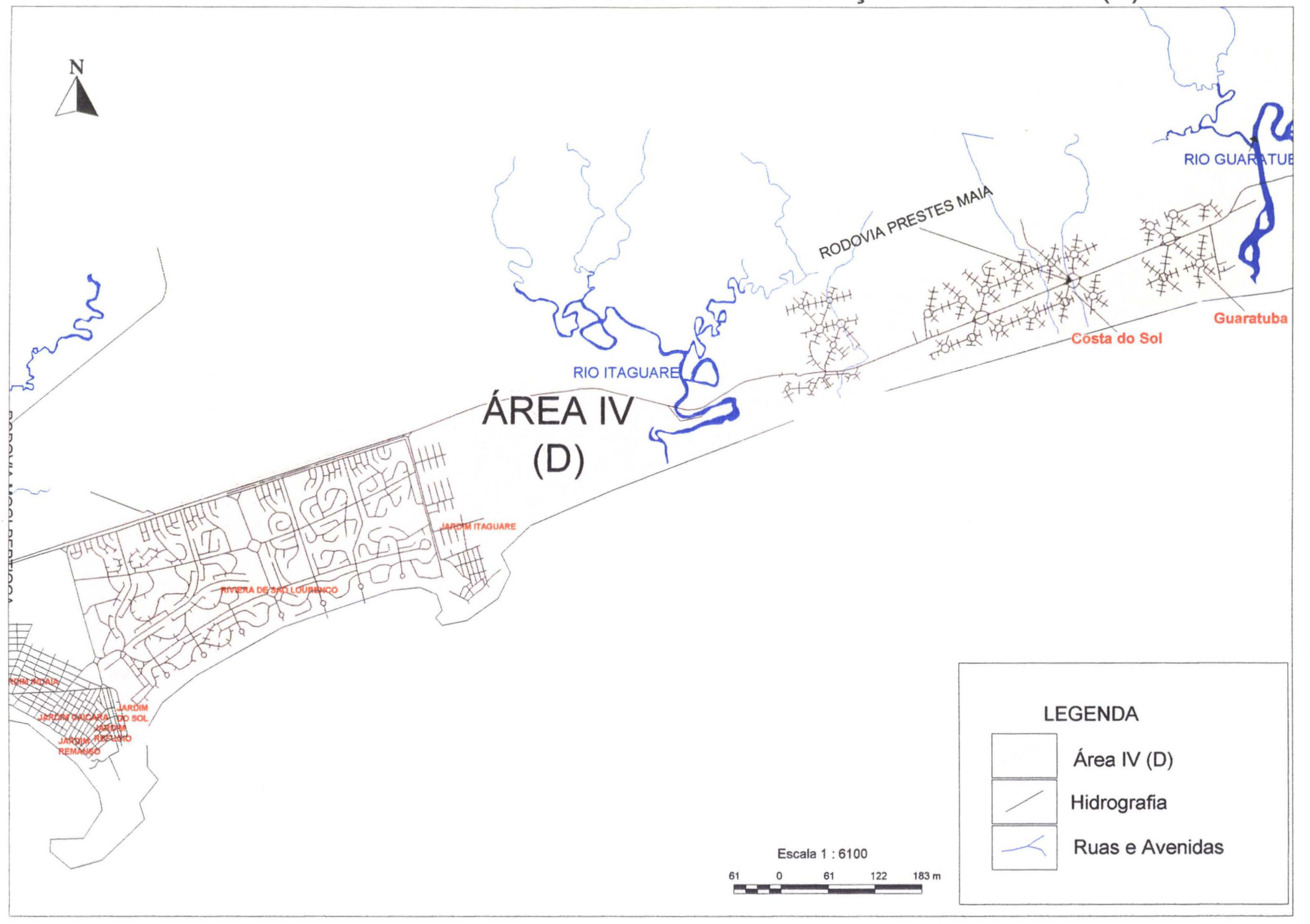

z
学
O
जे 


\section{MUNICÍPIO DE BERTIOGA: MAPA DE LOCALIZAÇÃO DA ÁREA V (E)}

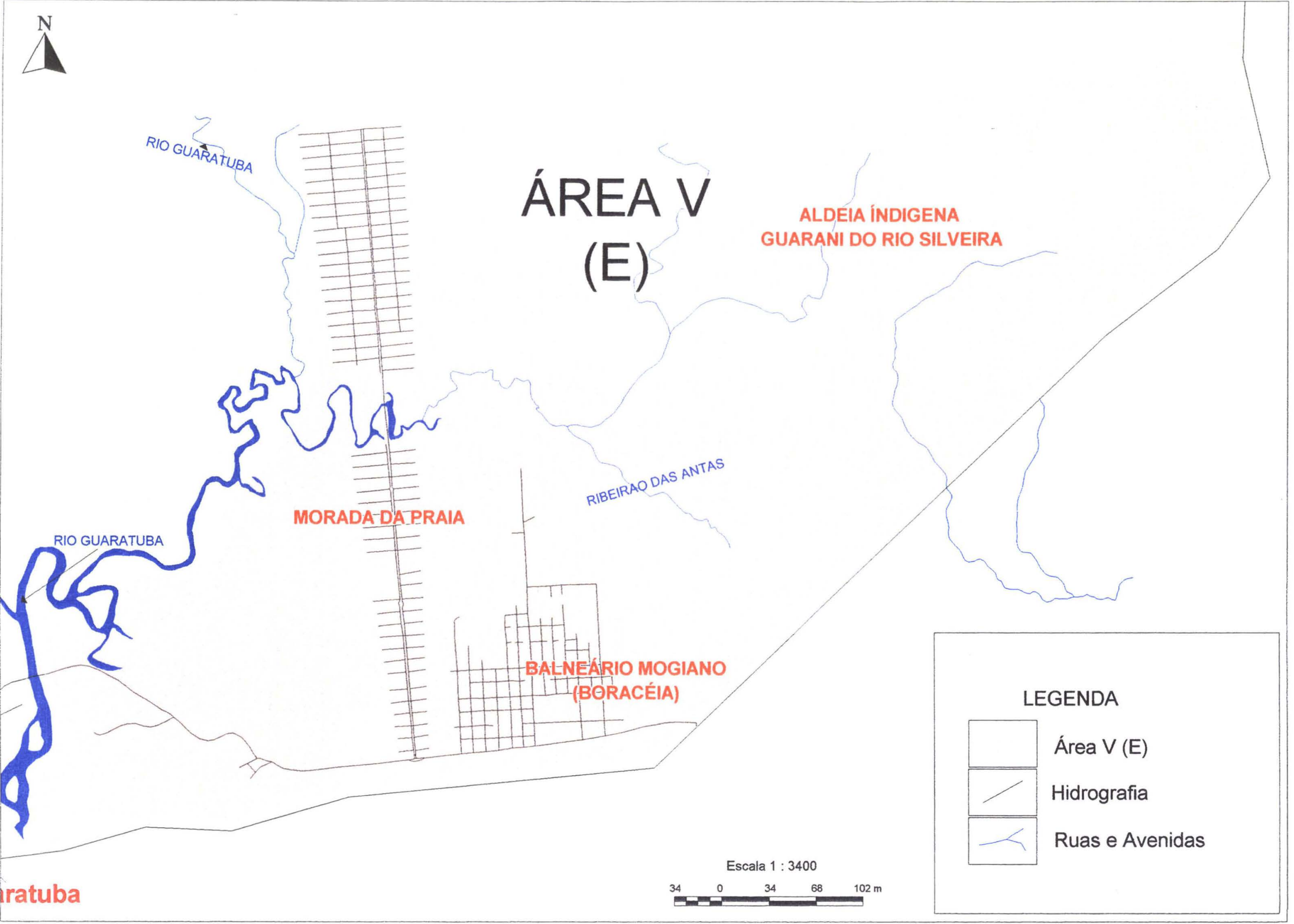


Anexo 17 - Quadro 1 - Atividades desenvolvidas no Projeto Bertioga

\section{Município Saudável e seus participantes}

\begin{tabular}{|c|c|c|c|c|}
\hline AREA & ATIVIDADE & Atividades FSP & 4 BAIRRO & NOME \\
\hline 1. & médico funcionário público & cl DS1 & & Aluísio Bichir \\
\hline 2. & arquiteto funcionário público & OS1 & & Amauri F. Tavares \\
\hline 3. & $\begin{array}{r}\text { chefe de ensino funcionária } \\
\text { pública }\end{array}$ & OS1 & & Aparecida Maria Brasil \\
\hline 4. & $\begin{array}{r}\text { assistente social funcionária } \\
\text { pública }\end{array}$ & OS1 & & Célia Regina Migues Rodrigues \\
\hline 5. & psicóloga (outros) & Cl OS1 & & Célia Regina Pereira \\
\hline 6. & $x$ & Cl OS1 & & Diney Lyra \\
\hline 7. & $\begin{array}{r}\text { agente de saúde funcionária } \\
\text { pública }\end{array}$ & OS1 & & Eliana Avelino dos Santos \\
\hline 8. & $\begin{array}{r}\text { agente de saúde funcionária } \\
\text { pública }\end{array}$ & OS1 & & Eliana Paulino Cunha Fernandes \\
\hline 9. & $\begin{array}{r}\text { Vigilância sanitária funcionária } \\
\text { pública }\end{array}$ & SM $\quad$ CI OS1 & & Elisabete de Castro Alves \\
\hline 10. & $\begin{array}{r}\text { agente de saúde funcionária } \\
\text { pública }\end{array}$ & OS1 & & Elizangela da Silva Bernardino \\
\hline 11. & $\begin{array}{r}\text { agente de saúde funcionária } \\
\text { pública }\end{array}$ & OS1 & & Ezeuda Alves Martins \\
\hline 12. & $\begin{array}{r}\text { agente de saúde funcionária } \\
\text { pública }\end{array}$ & DS1 & & Fátima de L. Ramos da S. Vieira \\
\hline 13. & $\begin{array}{r}\text { diretora de turismo funcionária } \\
\text { pública }\end{array}$ & $\begin{array}{lll}\text { SM } & \text { CI } & \text { OS1 }\end{array}$ & & Lais Helena Prearo Jacopucci \\
\hline 14. & $\begin{array}{r}\text { agente de saúde funcionária } \\
\text { pública }\end{array}$ & OS1 & & Lúcia Maria Vasconcelos de Mello \\
\hline 15. & $\begin{array}{r}\text { agente de saúde funcionária } \\
\text { pública }\end{array}$ & OS1 & & Maria José Pereira Barba \\
\hline 16. & funcionária pública & OS1 & & Maria Madalena E. de Sousa \\
\hline 17. & psicóloga & OF Cl OS1 & & Miriam Costejan \\
\hline 18. & $\begin{array}{r}\begin{array}{r}\text { zootecnista funcionária } \\
\text { pública }\end{array} \\
\end{array}$ & OS1 & & Mylene Lyra Pedroso \\
\hline 19. & $\begin{array}{r}\text { engenheiro civil/economista } \\
\text { funcionário público }\end{array}$ & OF $\quad \mathrm{Cl}$ OS1 & & Paulo Roberto Maria Velzi \\
\hline 20. & $\begin{array}{r}\text { agente de saúde funcionária } \\
\text { pública }\end{array}$ & OS1 & & Rizelda Alves Ribeiro \\
\hline 21. & funcionário público & OS1 & & Roberto Teixeira Ribeiro \\
\hline 22. & AOS & DS1 & & Simone Cristina Barrol \\
\hline 23. & $\begin{array}{r}\text { agente de saúde funcionária } \\
\text { pública }\end{array}$ & OS1 & & Simone Costa de Oliveira \\
\hline 24. & funcionária pública & OS1 & & Sônia Regina Gutiez \\
\hline 25. & FUNASA & OS1 & & Wagner Lamônica Lopes Fernandes \\
\hline \multirow[t]{2}{*}{26.} & funcionária pública & OS1 & & Zaine Bichir Cassis \\
\hline & 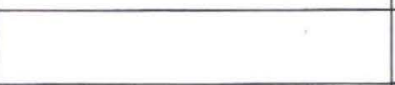 & $\begin{array}{c}33 \text { participantes } \\
\text { da OS1 }\end{array}$ & & \\
\hline 1. $\mathrm{A}$ & religioso & PE & Jd Itapamari & Adaltivo Gonçalves da Silva \\
\hline 2. $E$ & marceneiro/ carpinteiro & $\mathrm{PE}$ & Boracéia & Ademilson Soares da Silva \\
\hline 3. $B$ & empreiteiro de mão de obra & PE & Jard Rio da Granja & Adiel Pereira \\
\hline 4. A & $\mathrm{x}$ & PE & Sítio São João & Adriana Mara da Silva \\
\hline 5. A & comerciante & PE & Vila Itapanhaú & Alcir Scariot (Tiko) \\
\hline 6. $E$ & do lar & PE & Boracéia & Antônia Aparecida de Paula Oliveira \\
\hline 7. $\mathrm{B}$ & diretora de escola & PE & Jd Rio da Praia & Antônia Aparecida dos Santos \\
\hline 8. $\mathrm{C}$ & comerciante & PE & Jd Rafael & Antônio Carlos Magalhães Santos \\
\hline 9. $\mathrm{C}$ & profissional de comunicação & PE & Indaiá & Antônio Lombardi Junior \\
\hline
\end{tabular}




\begin{tabular}{|c|c|c|c|c|}
\hline 10. D & comerciante & PE & Guaratuba & Antônio Luiz de Souza(Toninho Guaratuba) \\
\hline 11. C & vereador & $\mathrm{PE}$ & Indaiá & Antônio Rodrigues Filho \\
\hline 12. $\mathrm{C}$ & $\mathrm{x}$ & $\overline{P E}$ & Jd Rafael & Aparecido Soares de Mello \\
\hline 13. D & vice-prefeito & $\mathrm{PE}$ & Riviera & Artur Guilherme Richter \\
\hline 14. $\mathrm{A}$ & comerciante & $\overline{P E}$ & Sítio São João & Assunta Ferracioli \\
\hline 15. $\mathrm{A}$ & construção civil & $\mathrm{PE}$ & Jd Vicente de Carvalho II & Boaventura Francisco Vitório \\
\hline 16. $\mathrm{A}$ & funcionário público & $\overline{\mathrm{PE}}$ & Jd Lido & Bolivar Barbanti Junior \\
\hline 17. $\mathrm{C}$ & comerciante & PE & Indaiá & Bruno José Ribeiro \\
\hline 18. $\mathrm{C}$ & representante comercial & PE & Indaiá & Celso da Silva Martinez \\
\hline 19. C & vereador & $\mathrm{PE}$ & Jd Indaiá & Claudenir Vieira da Silva \\
\hline 20. A & comerciante & PE & Vila Tamoios & Cláudio Cardoso dos Santos \\
\hline 21. & diretora de escola & PE & Guarujá & Cristina Zanella C. de Araújo \\
\hline 22. $E$ & farmacêutica & $\mathrm{PE}$ & Boracéia & Dayse Oliveira Silva Fernandes Almeida \\
\hline 23. D & religioso & PE & Jd São Lourenço & Denis Eduardo Hartung Vallongo \\
\hline 24. $\mathrm{A}$ & comerciante & PE & Sítio São João & Donizete Aparecido da Silva \\
\hline 25. D & músico & $\overline{\mathrm{PE}}$ & Guaratuba & Edenilton Eloi dos Santos \\
\hline 26. C & servente & $\mathrm{PE}$ & Indaiá & Edith Maria Medeiros da Silva \\
\hline 27. C & advogado & PE & Jd Vista Linda & Eduardo Pereira de Abreu \\
\hline 28. A & arquiteta & PE & Centro & Elizabeth de Fátima Correia \\
\hline 29. $E$ & motorista & PE & Boracéia & Elton Nazaré de Oliveira \\
\hline 30. B & autônomo & PE & Jd Rio da Granja & Eraldo José R. dos Santos \\
\hline 31. $\mathrm{A}$ & comerciante & $\mathrm{PE}$ & Centro & Fábio Mazzoni \\
\hline 32. $\mathrm{C}$ & aposentado & $\mathrm{PE}$ & Jd Vista Linda & Fisao Tanabe \\
\hline 33. C & aposentado & $\mathrm{PE}$ & Indaiá & Francisco Matias \\
\hline 34. C & $\mathrm{x}$ & $\mathrm{PE}$ & Jd Indaiá & Francisco Mendes de Castro \\
\hline 35. B & motorista & PE & Jd Rio da Praia & Francisco Pedro dos Santos \\
\hline 36. $E$ & chefe de segurança & PE & Morada da Praia & Fred George Cano \\
\hline 37. $E$ & motorista & $\overline{P E}$ & Boracéia & Geraldo Fernandes da Silva \\
\hline 38. $\mathrm{C}$ & assessora parlamentar & PE & Jd Indaiá & Guilhermina Vieira Dantas da Silva \\
\hline 39. D & agrimensor & $\mathrm{PE}$ & Parque Jabaquara & Hamilton Teixeira Martinez \\
\hline 40. D & comerciante & $\mathrm{PE}$ & Jd São Lourenço & Heloisa Helena Araújo Duarte Ribeiro \\
\hline 41. B & hotelaria & PE & Vila Agaó & Herbert Mendes Dutzmann \\
\hline 42. $\mathrm{D}$ & aposentado & $\mathrm{PE}$ & Costa do Sol & Hercilio Arcanjo Luz \\
\hline 43. B & hotelaria & SM & Jd Maitinga & Hermógenes Fiaschi Dores \\
\hline 44. B & recepcionista & PE & Jd Ana Paula & Icledimilson Sampaio Silva \\
\hline 45. C & hotelaria & PE & Indaiá & Irene Vaz Pinto Lyra \\
\hline 46. & diretora de escola & SM & Santos & Ivana Silva dos Santos \\
\hline 47. C & inspetora de escola & SM & Jd Indaiá & Ivani Aparecida Correia \\
\hline 48. C & comerciante & PE & Jd Rafael & Ivone Pires de Almeida Guerreiro \\
\hline 49. C & $\mathrm{x}$ & PE & Indaiá & Jacobi Pereira \\
\hline 50. D & construção civil & PE & Boracéia & Jair Rosário Braz \\
\hline 51. C & pintor & $\mathrm{PE}$ & Jd Caiçara & João Aparecido Marmé Gouveia \\
\hline 52. $\mathrm{A}$ & aposentado & PE & Jd Vicente de Carvalho II & João Carlos Riesco \\
\hline 53. B & aposentado & $\mathrm{PE}$ & Jd das Canções & Joaquim de Oliveira Miranda \\
\hline 54. $\mathrm{E}$ & militar & PE & Boracéia & Joel dos Santos \\
\hline 55. C & artesão & PE & Indaiá & John Julius Balthazar \\
\hline 56. $E$ & comerciante & $\mathrm{PE}$ & Boracéia & Jorge Attilio Pascucci \\
\hline 57. D & $\begin{array}{r}\text { coordenador conjunto } \\
\text { habitacional }\end{array}$ & $\overline{\mathrm{PE}}$ & Costa do Sol & José Adelton Cordeiro da Silva \\
\hline 58. A & religioso & $\mathrm{PE}$ & & José Cardoso da Silva \\
\hline 59. C & $\mathrm{x}$ & PE & Indaiá & José Carlos Rodrigues (Zezinho) \\
\hline 60. D & Advogado & SM & Riviera & José Cláudio de Abreu \\
\hline 61. A & pescador & $\mathrm{PE}$ & Vila Tupi & José Deodato da Silva \\
\hline 62. B & armador & $\overline{P E}$ & Maitinga & José Evangelista dos Santos \\
\hline 63. $\mathrm{A}$ & motorista & $\overline{\mathrm{PE}}$ & Jd Paulista & José Lopez Sobrinho \\
\hline 64. $\mathrm{A}$ & empresário & $\mathrm{PE}$ & Centerville & José Luiz Zuppani \\
\hline 65. D & $\mathrm{x}$ & PE & Vila Clementina & José Roberto Ferraro \\
\hline 66. A & comerciante & $\mathrm{PE}$ & Chácara Caiubura & José Roberto Raymundo \\
\hline 67. A & $\mathrm{x}$ & $\mathrm{PE}$ & Jd Albatroz II & José Viveiros Nunes \\
\hline 68. A & gerente & $\mathrm{PE}$ & Sítio São João & Juarez Fragoso Guedes \\
\hline 69. A & escrituraria (outros) & SM & Vila Agaó & Katia Hidalgo Daia \\
\hline 70. $\mathrm{A}$ & comerciante & SM & Vila Tamoios & Lauro Marques Canoilas \\
\hline 71. $\mathrm{A}$ & ambulante & $\overline{P E}$ & Jd Paulista & Lourivaldo Santos Maciel \\
\hline 72. D & arquiteto & $\mathrm{PE}$ & Riviera & Luis Carlos Ribeiro Marques \\
\hline 73. $\mathrm{A}$ & funcionário público & $\overline{\mathrm{PE}}$ & Centro & Luiz Antônio Batista Simōes \\
\hline 74. D & caseira & SM & Guaratuba & Lusia Arlindro \\
\hline 75. $\mathrm{A}$ & aposentada & SM & Jd Vista Linda & Lydia Altomani Sanchez \\
\hline
\end{tabular}




\begin{tabular}{|c|c|c|c|c|}
\hline 76. B & porteiro (outros) & $P E$ & Rio da Praia & Mamede Barbosa de Oliveira \\
\hline 77. D & vereador & $\mathrm{PE}$ & Jd São Lourenço & Manoel Batista Pinto \\
\hline 78. C & funcionário público & $\mathrm{PE}$ & Indaiá & Marcelo dos Santos \\
\hline 79. C & professora/ comerciante & SM & Indaiá & Márcia Maria Rúbio Marchi \\
\hline 80. B & operadora de caixa & $\mathrm{PE}$ & Jd Maitinga & Marcia Maria Rivas Balboa \\
\hline 81. $E$ & médica & PE & Praça Fco Ribeiro Nogueira & Márcia Rocha Lafuente \\
\hline 82. $\mathrm{A}$ & $\mathrm{x}$ & $\mathrm{PE}$ & Jd Vicente de Carvalho II & Marcio Cassiano \\
\hline 83. $\mathrm{E}$ & autônomo & $\overline{P E}$ & Boracéia & Marcos Antonio Andrade dos Santos \\
\hline 84. $\mathrm{A}$ & funcionário público & $\mathrm{PE}$ & Jd Vicente de Carvalho II & Marcos Antônio do Amparo \\
\hline 85. C & vidreiro & $\mathrm{PE}$ & Chácara Vista Linda & Marcos de Oliveira \\
\hline 86. D & hotelaria & $\mathrm{PE}$ & Guaratuba & Maria Aparecida Boscaratto \\
\hline 87. A & desempregada & $\mathrm{PE}$ & Jd Vicente de Carvalho II & Maria Aparecida Ferreira Borges \\
\hline 88. C & comerciante & $\mathrm{PE}$ & Jd Vista Linda & Maria Cristina Guzzo \\
\hline 89. A & cabeleireira (outros) & $\mathrm{PE}$ & Jd Vicente de Carvalho II & Maria de Oliveira Viana \\
\hline 90. C & motorista & $\mathrm{PE}$ & Jd Rafael & Maria do Céu Carvalho Reol Trancho \\
\hline 91. B & ambulante & $\mathrm{PE}$ & Jd Paulista & Maria Eleuza Reis de Araújo \\
\hline 92. $\mathrm{E}$ & inspetora de escola & $\overline{P E}$ & Boracéia & Maria Eloísa de Carlos Nogueira \\
\hline 93. C & advogada & $\overline{\mathrm{PE}}$ & Jd Indaiá & Maria Francisca Barros \\
\hline 94. D & secretária & $\mathrm{PE}$ & Riviera & Maria José Penha Moreira \\
\hline 95. $\mathrm{E}$ & do lar & $\mathrm{PE}$ & Boracéia & Maria Lúcia de Souza \\
\hline 96. C & $\mathrm{x}$ & $\overline{\mathrm{PE}}$ & Indaiá & Maria Lúcia dos Santos \\
\hline 97. A & comerciante & $\overline{\mathrm{PE}}$ & Jd Albatroz I & Maria Lúcia Rodrigues Lauredo \\
\hline 98. $\mathrm{E}$ & do lar & $\overline{\mathrm{PE}}$ & Morada da Praia & Marlene Troiette Beccarini \\
\hline 99. B & marceneiro & SM & Jd Rio da Praia & Martins José dos Santos \\
\hline 100. B & empresária & $\mathrm{PE}$ & Mangue Seco & Mary Mendes da Silva \\
\hline 101. A & comerciante & $\mathrm{PE}$ & Centro & Mikiko Miki \\
\hline 102. B & religioso & $\mathrm{PE}$ & Jd Rio da Granja & Moacir Bezerra Joventino \\
\hline 103. E & do lar & $\mathrm{PE}$ & Chácara Mogiano & Mônica Maria Ferreira \\
\hline 104. B & administrador de condomínio & $\overline{\mathrm{PE}}$ & Jd Rio da Praia & Nelson Lourenço \\
\hline 105. B & corretor de imóveis & $\mathrm{PE}$ & Jd Rio da Praia & Ney Moura Neme \\
\hline 106. A & arquiteto & $\mathrm{PE}$ & Centro & Nilo Nunes \\
\hline 107. B & diarista & $\overline{\mathrm{PE}}$ & Rio Raso & Nilza Moreira \\
\hline 108. D & funcionário público & $\mathrm{PE}$ & Jd São Lourenço & Odair Teixeira Pinto \\
\hline 109. A & corretor de imóveis & PE & Jd Helena Maria & Olga Anita Cordeiro da Silva \\
\hline 110. A & autônomo & $\mathrm{PE}$ & Centro & Orestes Alexandre do Amparo Filho \\
\hline 111. D & comerciante & $\overline{\mathrm{PE}}$ & Riviera & Osvaldo Sales Pereira \\
\hline 112. $\mathrm{B}$ & corretor de imóveis & $\overline{\mathrm{PE}}$ & Jd Maitinga & Paulo Roberto Marcílio Dantas \\
\hline 113. A & comerciante & $\mathrm{PE}$ & & Paulo Sérgio Martinez \\
\hline 114. A & comerciante & $\overline{P E}$ & Jd Albatroz I & Pedro Patrício \\
\hline 115. B & comerciante & $\mathrm{PE}$ & Jd Rio da Praia & Pérsio Dias Pinto \\
\hline 116. A & funcionário público & $\overline{\mathrm{PE}}$ & Centerville & Persival Ribeiro Pereira \\
\hline 117. A & diretora de escola & $\mathrm{PE}$ & Jd Lido & Regina Garça Barbanti \\
\hline 118. A & profissional de comunicação & $\mathrm{PE}$ & Vila Tupi & Reuben Nagia Zaidan \\
\hline 119. D & $\mathrm{x}$ & $\overline{P E}$ & Riviera & Rita de Cássia Caetano Bárbara \\
\hline 120. C & farmacêutico & $\overline{\mathrm{PE}}$ & Chácara Vista Linda & Ruben Cesar Leyva \\
\hline 121. B & $\mathrm{x}$ & $\mathrm{PE}$ & Vila Agaó & Sandra lara de Carvalho \\
\hline 122. C & $\mathrm{x}$ & $\mathrm{PE}$ & Chácara Vista Linda & Saulo Juvêncio da Cruz (Gaúcho) \\
\hline 123. B & autônomo & $\overline{\mathrm{PE}}$ & Jd das Canções & Sebastiāo Lourenço dos Santos \\
\hline 124. $B$ & comerciante & $\mathrm{PE}$ & Jd Rio da Praia & Seiho Iha \\
\hline 125. B & diarista & $\overline{\mathrm{PE}}$ & Jd Rio da Granja & Selma Bispo Santiago \\
\hline 126. A & assistente social & $\mathrm{PE}$ & Itapanhaú & Shirley Aparecida Alvarenga Souza \\
\hline 127. D & comerciante & PE & Riviera & Sílvio José Magalhães \\
\hline 128. B & comerciante & $\mathrm{PE}$ & Vila Agaó & Solange Maria Fontes Togliosca \\
\hline 129. A & construção civil & $\mathrm{PE}$ & Jd Vicente de Carvalho II & Sônia Maria Gonçalves Chaves \\
\hline 130. C & comerciante & $\overline{\mathrm{PE}}$ & Jd Vista Alegre & Terezinha Sousa Rodrigues de Matos \\
\hline 131. D & $\mathrm{x}$ & $\mathrm{PE}$ & Vila Tibúrcia & Tibúrcia Maria de Jesus \\
\hline 132. B & aposentado & $\overline{\mathrm{PE}}$ & Jd das Cançōes & Valdecir Lima \\
\hline 133. $\mathrm{C}$ & comerciante & $\overline{\mathrm{PE}}$ & Jd Indaiá & Valdemar da Silva (Valdir) \\
\hline 134. A & $\mathrm{x}$ & $\mathrm{PE}$ & Jd Vicente de Carvalho II & Valdemir de Carvalho Barbosa \\
\hline 135. D & hotelaria & $\mathrm{PE}$ & Jd São Lourenço & Valdir Ribeiro Junior \\
\hline 136. B & secretária & $\overline{P E}$ & Jd Maitinga & Valéria Andrade Barbosa \\
\hline 137. C & $\mathrm{x}$ & $\mathrm{PE}$ & Jd Vista Linda & Walter dos Reis \\
\hline 138. A & aposentado & $\overline{\mathrm{PE}}$ & Jd Albatroz II & Welington Bitencourt \\
\hline 139. A & $\mathrm{x}$ & $\overline{\mathrm{PE}}$ & Jd Paulista & Wilson Aparecido Morais \\
\hline \multirow[t]{2}{*}{ 140. C } & militar & $\mathrm{PE}$ & Indaiá & Wilson das Neves \\
\hline & & $\begin{array}{c}\text { Total de } 140 \\
\text { participantes da PE }\end{array}$ & & \\
\hline
\end{tabular}




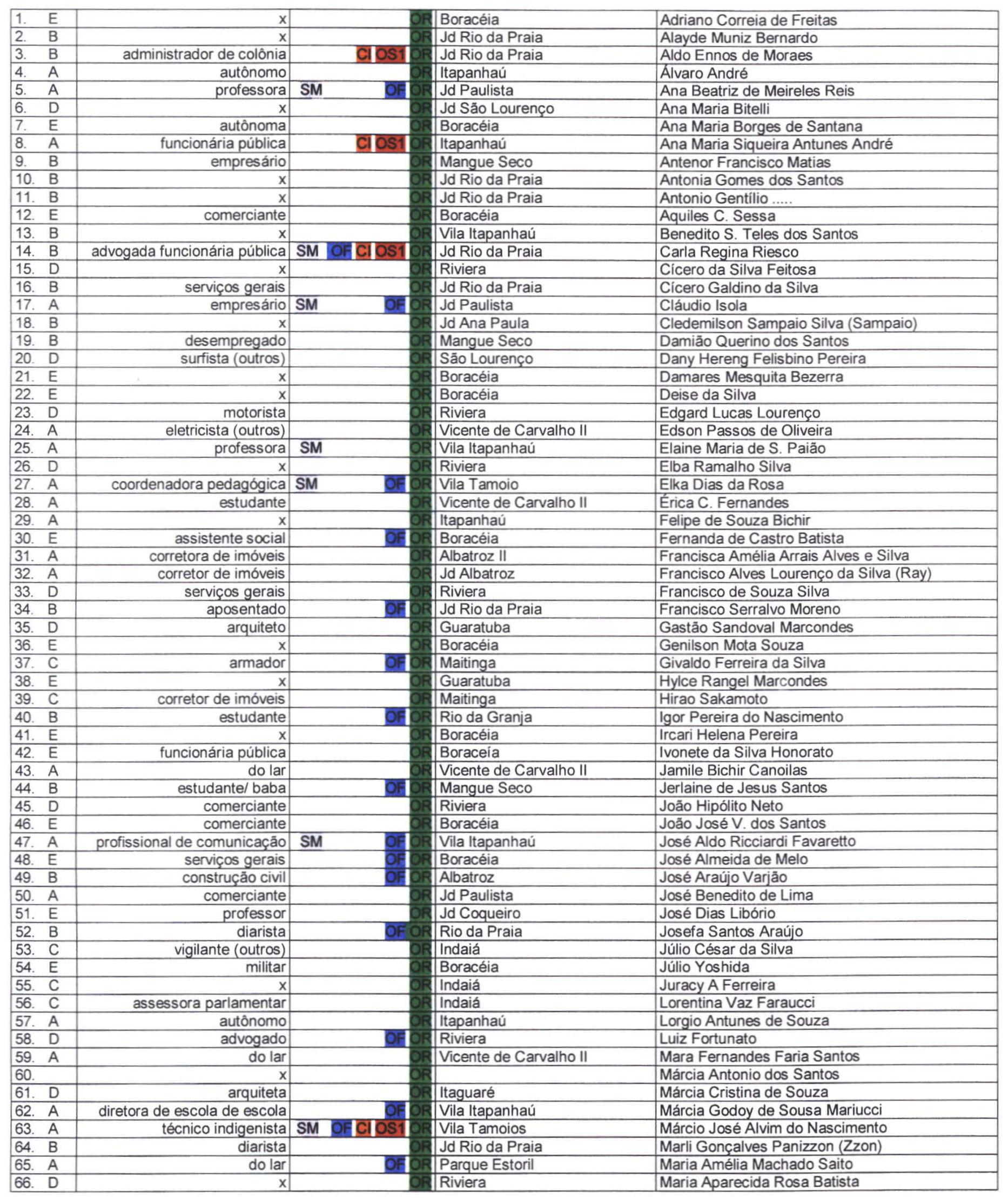




\begin{tabular}{|c|c|c|c|c|}
\hline 67. C & funcionário público & SM & Indaiá & Maria do Carmo Moraes Leroy \\
\hline 68. C & comerciante & & Indaiá & Maria do Carmo Moraes Rubio \\
\hline 69. B & diarista & & Jd Rio da Praia & Maria Josefa dos Anjos \\
\hline 70. $\mathrm{E}$ & comerciante & & Boracéia & Maria José Pereira Siqueira \\
\hline 71. D & professora & SM & Riviera & Maria Julieta Farah Lanças \\
\hline 72. $\mathrm{B}$ & professora & & Vila Tamoios & Maria Lina Amâncio \\
\hline 73. D & gerente & & Riviera & Maria Lizenilde Lima Costa \\
\hline 74. A & professora & & Vila Tamoios & Maria Salete Almeida do Nascimento \\
\hline 75. A & do lar & & Vila Tamoios & Marilena GuSMan Moreira \\
\hline 76. $\mathrm{C}$ & $\mathrm{x}$ & & Jd Indaiá & Marilene Victor Muniz \\
\hline 77. D & $\mathrm{x}$ & & Riviera & Maristânia F. S. Gomes \\
\hline 78. B & funcionário público & & Jd Rio da Praia & Maurício Antunes Quirino \\
\hline 79. A & funcionário público & SM & Parque Estoril & Maurício dos Santos Souza \\
\hline 80. A & do lar & & Centro & Mercedes Bichir de Oliveira \\
\hline 81. A & funcionária pública & & Centro & Nacima Mahamud Navajas \\
\hline 82. A & comerciante & & Albatroz I & Nazareth Lauredo Rodrigues \\
\hline 83. $\mathrm{E}$ & $x$ & & Boracéia & Nelcy Santos da Silva \\
\hline 84. C & funcionária pública & & Indaiá & Neuza Ana Santos do Rosário \\
\hline 85. $E$ & diarista & & Boracéia & Neuza Tereza Fermino \\
\hline 86. B & do lar & SM & Jd Rio da Praia & Neuza Maria Zaina Ferreira \\
\hline 87. B & vereador & & Rio da Praia & Ney Moura Nehme \\
\hline 88. $\mathrm{E}$ & funcionária pública & & Boracéia & Nilda O de Souza \\
\hline 89. D & professora & & Jd São Lourenço & Norma Regina Paulo Pinto \\
\hline 90. $\mathrm{B}$ & diarista & & Jd Rio Raso & Raida Santana \\
\hline 91. $\mathrm{E}$ & $\begin{array}{r}\text { operadora de maquina de } \\
\text { lavanderia (outros) }\end{array}$ & & Boracéia & Raquel Oliveira de Souza \\
\hline 92. A & inspetor de escola & & Vila Itapanhaú & Raul Lobo \\
\hline 93. B & construção civil & & Jd Rio da Praia & Renato Moraes Siqueira \\
\hline 94. $\mathrm{E}$ & $\mathrm{x}$ & & Boracéia & Ricardo da Silva Honorato \\
\hline 95. C & ambulante & & Indaiá & Rita de Cássia Muniz \\
\hline 96. A & cozinheira (outros) & & Centro & Rosicleia da Conceição \\
\hline 97. B & diarista & & Jardim Rio raso & Rosilda Santana \\
\hline 98. $\mathrm{E}$ & ambulante & SM & Boracéia & Ruy Lobato de Souza \\
\hline 99. C & engenheira funcionária pública & & Jd Albatroz & Silvana Steinwacher Cunha \\
\hline 100. D & comerciante & & Riviera & Silvia Maria de Abreu Fortunato \\
\hline 101. B & professora & & Vila Tamoios & Sonia dos Santos Reis \\
\hline 102. D & aposentada & & Jd São Lourenço & Stella Maris Veloso Lioi \\
\hline 103. B & ambulante & & Jd Rio da Praia & Sueli Martins da Costa \\
\hline 104. A & farmacêutica & & Vila Itapanhaú & Tereza Cristina Pinho Favaretto \\
\hline 105. E & outros & & Boracéia & Ubirajara Gonçalves de Lima \\
\hline 106. A & jornalista & & Vicente de Carvalho II & Valdete Nilza da Silva \\
\hline 107. E & $\mathrm{x}$ & & Boraceía & Varnei F. dos Santos \\
\hline 108. E & professora & & Riviera & Violeta Ortega Gonzalez Ferreira \\
\hline 109. B & estudante & & Maitinga & Wilma de Melo Cavalcanti \\
\hline 110. C & empresário & & Indaiá & Wilson Rodrigues \\
\hline \multirow[t]{3}{*}{ 111. E } & $\mathrm{x}$ & & Guaratuba & Zenilde Braz Brandão \\
\hline & & $\begin{array}{l}37 \text { participantes } \\
\text { da PE e da OR }\end{array}$ & & \\
\hline & & $\begin{array}{c}\text { Total de141 } \\
\text { participantes das } \\
\text { OR }\end{array}$ & & \\
\hline 1. $\mathrm{D}$ & estudante & & Riviera & Adriana Arajs Marques \\
\hline 2. $\mathrm{B}$ & estudante & & Ria da Praia & Adriana Ferreira de Santana \\
\hline 3. $\mathrm{B}$ & estudante & & Rio da Praia & Alessandra Aparecida Ferreira de Santana \\
\hline 4. B & auxiliar administrativo (outros) & & Maitinga & Alessandro Gomes Garcia \\
\hline 5. $E$ & eletricista (outros) & & Boracéia & Alex de Souza \\
\hline$E$ & comerciante & & Boracéia & Alexandre Martins Lopes \\
\hline $\mathrm{A}$ & estudante & & Vicente de Carvalho & Aline do Amparo Santos \\
\hline 8. $\mathrm{A}$ & estudante & & Vila Itapanhaú & Aline Nunes de Oliveira \\
\hline 9. $\mathrm{D}$ & estudante & & Riviera & Amanda Arass Marques \\
\hline 10. $E$ & estudante & & Guaratuba & Ana Carolina Arlindo do Rosário \\
\hline 11. $\mathrm{D}$ & empresária & & Módulo 20 & Ana Leonor Castelo Branco Ferreira \\
\hline 12. D & decoradora (outros) & & Riviera & Ana Lúcia Casagrande de Oliveira \\
\hline 13. $\mathrm{E}$ & $\begin{array}{r}\text { funcionário público ( aux. } \\
\text { secretária ) }\end{array}$ & SM & Guaratuba & Andréia Janzioni Faria \\
\hline 14. $\mathrm{B}$ & estudante & SM & Jd. Rio da Praia & Andrezza Monteiro dos Santos \\
\hline
\end{tabular}




\begin{tabular}{|c|c|c|c|c|}
\hline 15. $\mathrm{B}$ & pintor & & Rio da Praia & Antônio Carlos Cordeiro Costa \\
\hline 16. $\mathrm{C}$ & vendedor & & Indaiá & Antônio José Peixoto Fernandes \\
\hline 17. $\mathrm{A}$ & estudante & & Jd Albatroz & Atila Aparecido de Miranda \\
\hline 18. $\mathrm{B}$ & do lar & & Jd. Rio da Praia & Benedita Aparecida André \\
\hline 19. $\mathrm{A}$ & pintor & & Vicente Carvalho II & Canivaldo Rodrigues Silva \\
\hline 20. $\mathrm{C}$ & auxiliar de escritório & & Vista Linda & Catiane de Oliveira Pinto Pereira \\
\hline 21. D & construção civil & & Riviera & Ciro Rors \\
\hline 22. $\mathrm{C}$ & do lar & & Vista Linda & Cleide Guerreira de Souza \\
\hline 23. A & estudante & & Vicente Carvalho & Clerison Betons Pereira da Silva \\
\hline 24. C & eletrotécnica(outros) & & Vista Linda & Dalva Pereira \\
\hline 25. A & professora & & |ltapanhaú & Dalvanete dos Santos Costa \\
\hline 26. B & motorista & & Jd Rio da Granja & Damião Quirino dos Santos \\
\hline 27. $\mathrm{B}$ & $\mathrm{x}$ & & Rio da Praia & Delvani Dutra de Almeida Santos \\
\hline 28. A & professora & & Vila Itapanhaú & Denise Dalseno \\
\hline 29. $\mathrm{E}$ & comerciante & & Boracéia & Diamantino de Sousa Batista \\
\hline 30. $\mathrm{B}$ & artesão & SM & Vila Agaó & Ditmar Schmidt \\
\hline 31. $\mathrm{C}$ & zelador & & Maitinga & Douglas Castro Gonçalves de Freitas \\
\hline 32. $\mathrm{B}$ & estudante & & Rio da Praia & Edson dos Santos Lardosa \\
\hline 33. B & fiscal & & Rio da Praia & Edson Siqueira Sina \\
\hline 34. B & construção civil & & Jd Rio da Granja & Elessandro Torres Pereira \\
\hline 35. A & balconista(outros) & & São João & Eliana de Oliveira \\
\hline 36. $E$ & auxiliar de escritório & & Jd B. Esperança & Érica Daniela de Oliveira \\
\hline 37. $\mathrm{B}$ & estudante & & Jd Rio da Granja & Eroldo Trindate de Jesus \\
\hline 38. A & estudante & & Vila Tamoios & Fabiana Almeida do Nascimento \\
\hline 39. A & faxineiro & & Vicente de Carvalho II & Fabiano Pereira de Sousa \\
\hline 40. $\mathrm{B}$ & estudante & & Rio da Praia & Fabrício Tavares de Souza \\
\hline 41. $\mathrm{A}$ & professora & & Jd Paulista & Fátima Aparecida Dias Barretto \\
\hline 42. $\mathrm{C}$ & construção civil & & Indaiá & Fernando Herrero \\
\hline 43. $E$ & do lar & & Boracéia & Filomena Mendes Pacheco \\
\hline 44. $E$ & construçāo civil & & Boracéia & Francisco Evangelista de Sousa \\
\hline 45. A & maquinista(outros) & & Vila Itapanhaú & Galditino José de Souza \\
\hline 46. $B$ & jardineiro(outros) & & Jd Rio da Granja & Geusivam Alves da Cruz \\
\hline 47. $\mathrm{C}$ & ambulante & & Indaiá & Hélio da Silva Marques \\
\hline 48. $\mathrm{C}$ & estudante & & Indaiá & Humberto G. B. Almeida \\
\hline 49. $\mathrm{B}$ & aposentado & & Jd. Rio da Praia & Isidoro Toito de Paula \\
\hline 50. $E$ & $\mathrm{x}$ & & Boracéia & Ivone de Castro Batista \\
\hline 51. C & do lar & SM & Indaiá & Ivone Peres da Rocha \\
\hline 52. C & pintor & & Maitinga & Januário José dos Santos Neto \\
\hline 53. A & estudante & & Jd Paulista & Jaqueline Cordeiro dos Santos \\
\hline 54. A & estudante & & Jd Paulista & Jéssica Aparecida do Amaral Carvalho \\
\hline 55. B & diarista & & Rio da Praia & Joana Galdino Duarte \\
\hline 56. $\mathrm{E}$ & $\begin{array}{r}\text { engenheiro eletricista } \\
\text { funcionário público }\end{array}$ & SM & Guaratuba & Joäo Alexandre Vieira \\
\hline 57. A & babá & & Vicente Carvalho II & Jocelia da Silva Santos \\
\hline 58. $\mathrm{A}$ & ambulante & & Centro & Jocilda Crisando dos Santos \\
\hline 59. C & zelador & & Maitinga & José A. de Figueiredo Irmão \\
\hline 60. D & carpinteiro(outros) & & Riviera & José Carlos de Barros \\
\hline 61. $B$ & pintor & & Ria da Praia & José Cordeiro Costa \\
\hline 62. $A$ & jardineiro & & Jd Albatroz & José E. Lima Vieira \\
\hline 63. B & técnico em elétrico(outros) & SM & Jd. Rio da Praia & José Jessé Paulo de Lima \\
\hline 64. B & marceneiro & SM & Rio da Praia & José Matias de Santana \\
\hline 65. B & servente & & Rio da Praia & José R. Moraes Siqueira \\
\hline 66. A & faxineiro & & Vicente de Carvalho II & José Raimundo Souza de Jesus \\
\hline 67. A & construção civil marceneiro & & $\mid$ Jd Albatroz I & José Rogério Laurentino Silva \\
\hline 68. B & do lar & & Rio da Praia & Josefa Gila Pereira \\
\hline 69. A & estudante & & Vicente de Carvalho II & Jucilene Santos da Silva \\
\hline 70. $\mathrm{B}$ & estudante & SM & Jd. Rio da Praia & Juliana Correia de Lima \\
\hline & $\begin{array}{l}\text { guarda municipal } \\
\text { funcionário público }\end{array}$ & & Vila Itapanhaú & Júlio Mariucci Filho \\
\hline 72. A & estudante & & Vila Itapanhaú & Karine Leal Pinheiro \\
\hline 73. $\mathrm{E}$ & estudante & & Boracéia & Leandra Suzini Venera \\
\hline 74. & estudante & & Itaim Paulista (São Paulo) & Leonardo Valentim de Albuquerque Taveiros \\
\hline 75. E & do lar & & Boracéia & Letilde da Silva \\
\hline 76. A & balconista & & Parque Estoril & Lidineide Gonçalves de Souza \\
\hline 77. A & construção civil & & Vicente de Carvalho II & Lourival Ferreira dos Santos \\
\hline 78. A & comerciante & & Jd Paulista & Lucélia \\
\hline 79. & comerciante & & & Lúcia M. Guerra \\
\hline
\end{tabular}




\begin{tabular}{|c|c|c|c|c|c|}
\hline 80. A & do lar & & OF & Jd. Rio da Praia & Luciene Silva Dias \\
\hline 81. A & motorista / pescador & SM & OF & Jd Paulista & Luíz Carlos Cortez \\
\hline 82. D & advogado & & OF & Riviera & Luiz Chardulo \\
\hline 83. $\mathrm{E}$ & militar & SM & OF & Boracéia & Luiz Fernando de Eiroz Brites \\
\hline 84. D & corretor de imóveis & & OF & Riviera & Luiz Fernando de Oliveira \\
\hline 85. A & aposentado & & OF & Centro & Marcello Marton \\
\hline 86. A & $\mathrm{x}$ & & OF & Vicente de Carvalho & Marcelo Monteiro dos Santos \\
\hline 87. A & estudante & & Of & Itapanhaú & Márcia Fernanda Costa Freita \\
\hline 88. A & estudante & & Of & Vicente de Carvalho II & Márcio Gomes dos Santos \\
\hline 89. D & empresário & & OF & Riviera & Marco Antônio Iglesias de Lima \\
\hline 90. B & do lar & SM & OF & Jd. Rio da Praia & Maria Alice Corrêa de Lima \\
\hline 91. B & do lar & & OF & Rio da Praia & Maria Betania F. Santana \\
\hline 92. $\mathrm{E}$ & comerciante & & OF & Boracéia & Maria Cisaltina Antunes \\
\hline 93. $\mathrm{B}$ & artesã / escultora & & OF & Jd. Rio da Praia & Maria das Neves de Castro \\
\hline 94. C & do lar & & OF & Indaiá & Maria de Loudes Abreu Aleixo \\
\hline 95. $\mathrm{A}$ & estudante & & OF & Jd Paulista & Maria de Lurdes Martins \\
\hline 96. B & serviços gerais & & OF & Rio da Praia & Maria Elisa Costa Leite \\
\hline 97. B & do lar & & OF & Vila Agaó & Maria José Baca Varela \\
\hline 98. B & do lar & & OF & Jd. Rio da Praia & Maria Josefa dos Santos \\
\hline 99. D & professora / aposentada & & OF & Riviera & Maria Lúcia Sommer Iglesias de Lima \\
\hline 100. B & serviços gerais & & OF & Rio da Praia & Maria Raimunda Santos \\
\hline 101. A & estudante & & OF & Vicente de Carvalho II & Maria Rodrigues de Sousa \\
\hline 102. A & construção civil & & OF & Jd Paulista & Marilena de Oliveira Moraes \\
\hline 103. B & do lar & & OF & Jd Rio da Granja & Marilene Almeida dos Santos \\
\hline 104. A & professora & & OF & Jd Albatroz II & Marina Miranda de Souza \\
\hline 105. A & jardineiro & & OF & Vicente de Carvalho II & Maurício Francisco Osario \\
\hline 106. A & professora & & OF & Jd Lido & Máyda Aparecida Zanirato \\
\hline 107. C & aposentado & & OF & Vila Caiçara & Milton Ferreira de Moraes \\
\hline 108. & marceneiro / eletricista & & OF & & Milton Pereira C. Filho \\
\hline 109. B & estudante & & OF & Jd Rio Raso & Miriä Santana Araújo \\
\hline 110. B & do lar & & QF & Rio da Praia & Neli Gomes Dias de Carvalho \\
\hline 111. B & construção civil & & of & Jd Rio da Granja & Nilton Pereira Lima \\
\hline 112. A & administradora de creche & & OF & Itapanhaú & Nilza Maria Lopes Biill \\
\hline 113. C & $\mathrm{x}$ & & OF & Indaiá & Olinda Lins Branco Almeida \\
\hline 114. A & estudante & SM & OF & Jd Paulista & Ordalia Alves Carneiro \\
\hline 115. C & aposentado & & OF & Indaiá & Osvaldo Dias \\
\hline 116. A & estudante & & OF & Vicente de Carvalho & Patricia Ciqueira Batista \\
\hline 117. A & estudante & & OF & Vicente de Carvalho & Paula Gargano de Souza \\
\hline 118. C & comerciante & & OF & Indaiá & Paulo Fernando Rofity \\
\hline 119. B & comerciante & & OF & Vila Agaó & Quirino Alves Carneiro Filho \\
\hline 120. E & estudante & & OF & Boracéia & Raphael Gomes da Silva \\
\hline 121. $\mathrm{B}$ & do lar & & OF & Jd Rio da Granja & Regiane Santos de Jesus \\
\hline 122. $\mathrm{C}$ & do lar & & OF & Indaiá & Romana Burka Pereira \\
\hline 123. $\mathrm{C}$ & do lar & & OF & Indaiá & Rosa da Rocha Moraes \\
\hline 124. B & do lar & & OF & Rio da Praia & Rosa Marques de Oliveira \\
\hline 125. B & $\mathrm{x}$ & & OF & Rio da Praia & Rosângela Vieira da Silva \\
\hline 126. B & faxineira & & OF & Jd Rio da Granja & Rosemere Oliveira da Silva \\
\hline 127. $\mathrm{B}$ & do lar & & OF & Rio da Praia & Rosimeire da Conceição Alves \\
\hline 128. C & auxiliar de escritório & & OF & Vista Linda & Rosimeire Souza Buffoni \\
\hline 129. D & caseiro & & OF & Riviera & Sadi Gessi \\
\hline 130. $\mathrm{A}$ & professora & & OF & Vila Tupi & Sandra Regina de Jesus \\
\hline 131. B & do lar & & OF & Jd. Rio da Praia & Sebastiana de Lima \\
\hline 132. A & zelador construção civil & & OF & Vicente de Carvalho & Simar Antônio \\
\hline 133. B & aposentado & & OF & Jd. Rio da Praia & Simião Ribeira Kierme \\
\hline 134. C & administrador(outros) & & OF & Indaiá & Sival Melo Silva \\
\hline 135. E & estudante & & $\overline{O F}$ & Boracéia & Stefânia Suzini Venera \\
\hline 136. C & do lar & & OF & Maitinga & Sueli Aparecida Garcia de Freitas \\
\hline 137. E & comerciante & & OF & Boracéia & Sueli Lins Albuquerque G. Silva \\
\hline 138. B & auxiliar de lavanderia & SM & OF & Vila Agaó II & Suzete Ribeiro da Silva \\
\hline 139. A & estudante & & $\mathrm{OF}$ & Jd Paulista & Tairine Alves Carneiro \\
\hline 140. A & funcionário público & & OF & Vila Itapanhaú & Tâmara Oganesouna Chernow \\
\hline 141. B & estudante & & OF & Vila Agaó & Tamires Voca Vorella \\
\hline 142. A & estudante & & OF & Jd Paulista & Tayara Alves Carneiro \\
\hline 143. A & estudante & & OF & Jd Paulista & Thais Vanessa Gouveira de Amorim \\
\hline 144. A & caseira & & OF & Parque Estoril & Valdelice Siqueira dos Santos \\
\hline 145. C & do lar & & OF & Indaiá & Valdenice Rodrigues Oliveira Maia \\
\hline
\end{tabular}




\begin{tabular}{|c|c|c|c|c|}
\hline 146. B & engenheiro & OF & Rio da Praia & Wladimir E.R.S. Grudzinslei \\
\hline & & $\begin{array}{r}44 \text { participantes } \\
\text { das OR e OF }\end{array}$ & & \\
\hline & & $\begin{array}{l}12 \text { participantes } \\
\text { das PE OR OF }\end{array}$ & & \\
\hline & & $\begin{array}{r}14 \text { participantes } \\
\text { das PE OF }\end{array}$ & & \\
\hline & & $\begin{array}{r}\text { Total de } 191 \\
\text { participantes das } \\
\text { OF }\end{array}$ & & \\
\hline 1. & advogado & SM & & Aguinaldo de Oliveira Dixon \\
\hline 2. & assistente & SM & & Ana Maria S. de Andrade Lima \\
\hline 3. & funcionária pública & SM & Guaratuba & Alailde Viana de Souza \\
\hline 4. & funcionária pública & SM & & Benedita Silva Cunha \\
\hline 5. & estudante & SM & & Caio Rodrigues Carvalhal \\
\hline 6. & & SM & & Clarissa Fernanda Zanirato \\
\hline 7. & estudante & SM & & Edimaura Nogueira Viura \\
\hline 8. & estudante & SM & & Elisabeth F. de L. Bruno \\
\hline 9. & funcionário público & SM & & Fernando ............ de Oliveira \\
\hline 10. & assistente & SM & & Irene de Oliveira \\
\hline 11. & funcionária pública & SM & Jardim Paulista & Ivonete Pinto da Conceição \\
\hline 12. & estudante & SM & & Jefferson Ricardo Espirito Santo \\
\hline 13. & funcionário público & SM & & João Alberto........... \\
\hline 14. & engenheiro & SM & & Jorge Elias Mahtuk \\
\hline 15. & advogado & SM & & José Antonio Rufino ................ \\
\hline 16. & & SM & & Juliana Furtado \\
\hline 17. & vereador & SM & Riviera & Jurandyr José Teixeira das Neves \\
\hline 18. & estudante & SM & & Karen Hidalgo Haia \\
\hline 19. & vereador & SM & & Ney Lyra \\
\hline 20. & $\mathrm{x}$ & SM & & Manoel Prieto Alvarez \\
\hline 21. & $x$ & SM & & Maria Cristina Perez \\
\hline 22. & funcionária pública & SM & & Maria Isabel R. da Silva \\
\hline 23. & $x$ & SM & & Mário Araújo \\
\hline 24. & estudante & SM & & Patrícia Enedino da Silva \\
\hline 25. & & SM & & Robson Alexandre Xavier da Silva \\
\hline 26. & estudante & SM & & Sabrina Monteiro Faria \\
\hline 27. & aposentado & SM & & Salvador L. Sanchez \\
\hline 28. & estudante & SM & & Samantha Ribeiro Ferreira \\
\hline 29. & jornalista & SM & & Sandra Silva \\
\hline 30. & estudante & SM & & Vanessa Auxiliadora Bueno \\
\hline \multirow[t]{4}{*}{31.} & estudante & SM & & Washington Luiz Araújo Ferreira \\
\hline & & $\begin{array}{r}\text { Total de } 574 \\
\text { participantes da } \\
\text { OS1 PE OR SM }\end{array}$ & & \\
\hline & & $\begin{array}{r}\text { Total de 41 } \\
\text { participantes do } \\
\text { SM presentes na } \\
\text { OS1 ou na PE ou }\end{array}$ & & \\
\hline & & $\begin{array}{r}\text { Total de } 69 \\
\text { participantes } \\
\text { reaistrados do SM }\end{array}$ & & \\
\hline
\end{tabular}




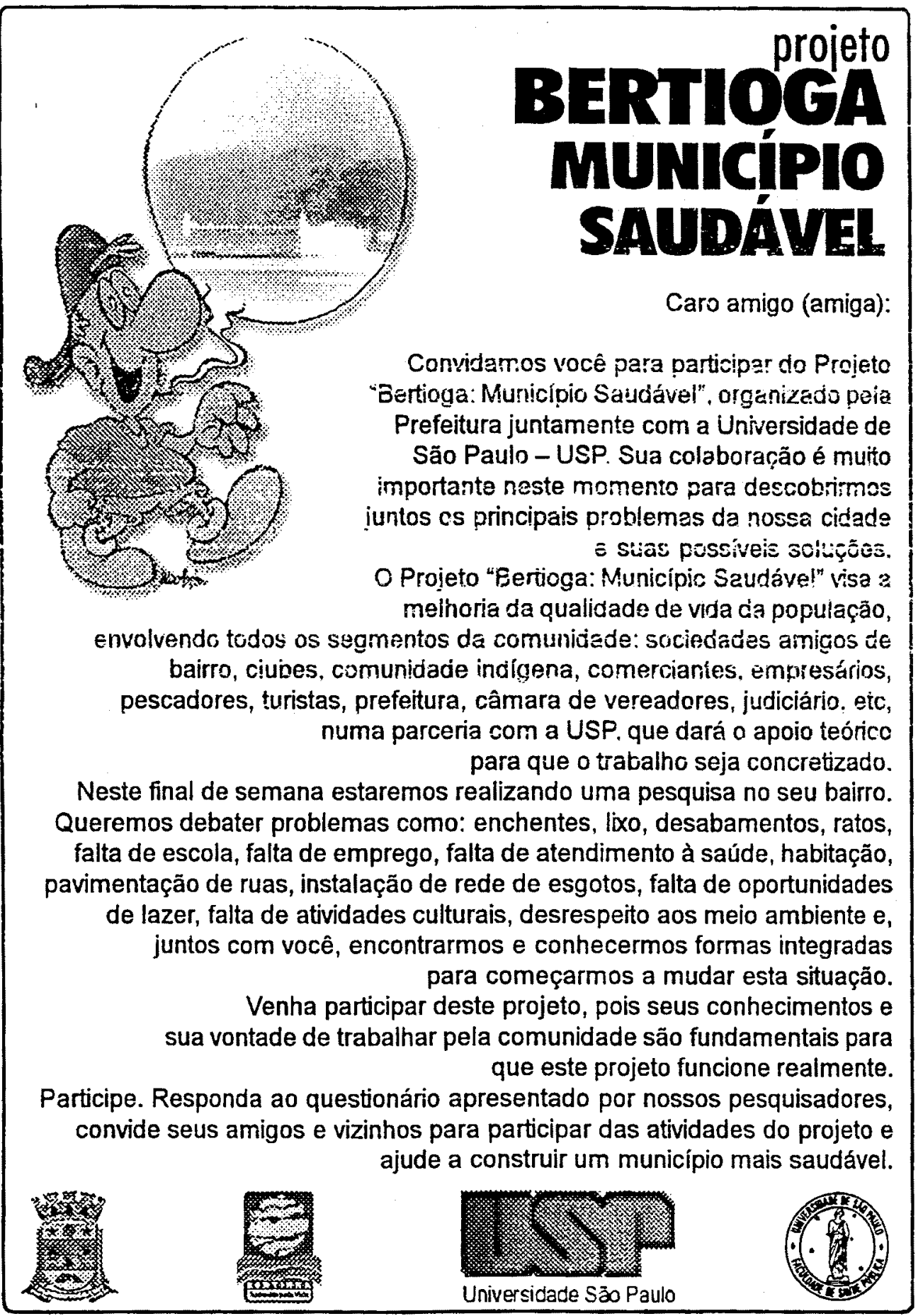




\section{ANEXO 19}

\section{Convite}

Oficinas Regionais

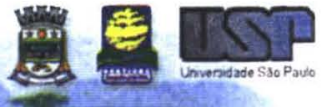

4

0

Convidamos voce para participar das Oficinas Regionais do Projeto Bertioga Municipio Saudavel. Na primeira fase, o Projeto fez uma pesquisa para descobrir quais as lideranças comunitarias, quais as percepcōes que estas pessoas tem sobre os problemas da cidade e quais os sonhos que gostariam percepcōes que estas pessoas tem sobre os problemas da cidade e quais os sonhos que gos

1. aprofundar questōes que possam contribuir para a melhoria da qualidade de vida.

- Sua colaboração e muito importante neste momento onde estaremos discutindo os principais 1 problemas de Bertioga. para juntos pensarmos alguns encaminhamentos.

- CALENDÁRIO dAS

OFICINAS REGIONAIS

Agosto/2000

$\neg \quad$ Dia 05/agosto

14h, Oficina - EMEIF Delphino S de Lima

14h, Oficina - EMEIF Rio da Praia

14h, Oficina - Classes Riviera S Lourenço

\section{Dia 06/agosto}

10h. Avaliaçäo - Casa da Cultura

14h, Oficina - EMEIF Indaia

14h. Oficina - EMEIF Boraceia

Dia 07/agosto

19h. Oficina - EMEIF Rio da Praia

19h. Oficina - Classes Riveira S. Lourenço

$19 \mathrm{~h}$, Oficina - EMEIF Boraceia.
Dia 08/agosto

19h, Oficina - EMEIF Delphino S. de Lima 19h. Oficina - EMEIF Indaia

Participe!

A cidade é nossa.

\section{Projeto Bertioga Município Saudável}

Prefeitura do Municipio de Bertioga

Universidade de São Paulo

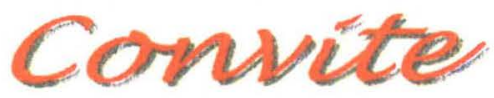

A Universidade de São Paulo tem o prazer de convidar V.Sa para participar do I Seminário Municipal do Projeto Bertioga Município Saudável a ser realizado no dia 09 de dezembro de 2000, às 13:30 horas, no SESC BERTIOGA.

\section{Programaçäo}

1-Abertura

2 - Projeto Bertioga Município Saudável Prof" Dra Marcia Faria Westphal - Faculdade de Saúde Pública - USP

3 - Apresentação das agendas dos Crupos das Oficinas do Futuro

4. Trabalhos de grupos: encaminhamentos das agendas e propostas de continuidade

5 - Definição da Comissäo Municipal do Projeto Bertioga Município Saudável 


\section{PROJETO BERTIOGA MUNICÍPIO SAUDÁVEL}

\section{CONVITE}

\section{OFICINAS DO FUTURO}

Convidamos você e seus filhos para participarem das Oficinas do Futuro do Projeto Bertioga Municipio Saudável.

Do que vamos falar nessas oficinas?

Vamos falar dos problemas da sua região, das causas dos problemas e quem está envolvido nesses problemas e também dos seus sonhos para uma Bertioga mais saudável.

O que vamos construir nessas oficinas?

Vamos determinar conjuntamente atividades e açōes para melhoria da qualidade de vida da população de Bertioga.

As Oficinas do Futuro serão realizadas durante o mês de outubro. Sua presença é muito importante e sua participação é fundamental para contribuir nas decisōes para a construção de Bertioga um município saudável.

Convide seus amigos e vizinhos.

ESCOLHA O MELHOR DIA PARA SUA PARTICIPAÇÃO ENTRE AS DATAS E LOCAIS ABAIXO:

DIA 07 DE OUTUBRO

16 h. Local: EMEIF Rio da Praia

DIA 08 DE OUTUBRO

16 h. Local: EMEIF Jardim Paulista

$16 \mathrm{~h}$. Local: EMEIF Boracéia

DIA O9 DE OUTUBRO

19 h. Local: EMEIF Indaiá

$19 \mathrm{~h}$. Local: EMEIF Riviera

DIA 10 DE OUTUBRO

19 h. Local: EMEIF Delphino S. de Lima

19 h. Local: EMEIF Rio da Praia

Telefones para maiores informações:

(011) 3066-7766:Ana, Victor, Marcelo, Rosilda e Francisco (013) 31731 58:Aluisio

(013) 3174000 Ramal 2053: Cidinha ou Lúcia 


\section{PROJETO BERTIOGA MUNICÍPIO SAUDÁVEL}

Caro(a) amigo(a):

Convidamos você, sua familia, seus vizinhos, seus amigos e sua entidade para participar do Projeto Bertioga Município Saudável, desenvolvido pela Universidade de São Paulo - USP em conjunto com a Prefeitura Municipal e diversos segmentos da comunidade bertioguense.

- Projeto Bertioga Município Saudável tem como objetivo a melhoria da qualidade de vida da população, envolvendo todos os segmentos da comunidade: sociedades amigos de bairro, clubes, comunidade indigena, comerciantes, empresários, pescadores, turistas, prefeitura, escolas municipais e estaduais, sâmara-de-vereadores, partidos políticos, judiciário, etc.

0 projeto tem previsão de duração de 4 anos, mas para que ele funcione realmente é importante fortalecer a participação da população para escolher o que é importante para uma Bertioga saudável.

Venha participar deste projeto através das OFICINAS do FUTURO onde serão discutidos problemas como: saneamento básico, saúde, habitação, lixo, preservação das praias, desemprego, educação, lazer, pavimentação de ruas, atividades culturais, meio ambiente.

TELEFONES PARA MAIORES INFORMACÕES:

(011) 3066-7766:Ana, Victor, Marcelo, Rosilda e Francisco

(013) 31731 58:Aluisio

(013) 3174000 RAMAL 2053: Cidinha ou Lúcia

CONTAMOS COM A SUA PRESENÇA 